\title{
Environmental Review for Site A/Plot M, Palos Forest Preserve, Cook County, Illinois
}

by R.P. Biang, C.R. Yuen, H.I. Avci, and R. Haffenden

Environmental Assessment and Information Sciences Division,

Argonne National Laboratory, 9700 South Cass Avenue, Argonne, Illinois 60439

June 1993

Work sponsored by United States Department of Energy, Chicago Operations Office 


\section{CONTENTS}

NOTATION $\ldots \ldots \ldots \ldots \ldots \ldots \ldots \ldots \ldots \ldots \ldots \ldots \ldots \ldots \ldots \ldots \ldots \ldots \ldots \ldots \ldots$ vii

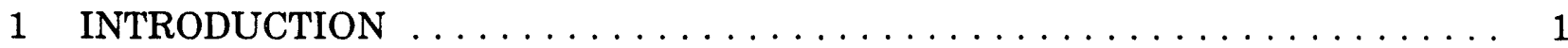

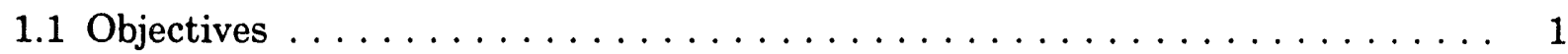

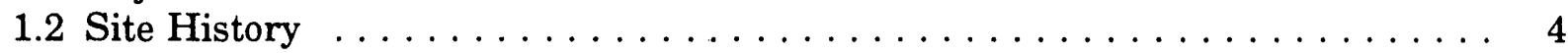

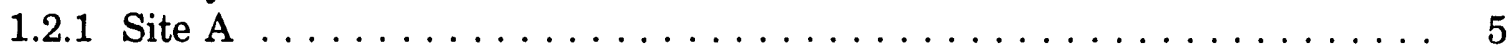

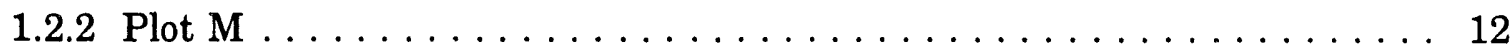

2 SITE ENVIRONMENT $\ldots \ldots \ldots \ldots \ldots \ldots \ldots \ldots \ldots \ldots$

2.1 Topography and Land Use $\ldots \ldots \ldots \ldots \ldots \ldots \ldots \ldots \ldots \ldots \ldots$

2.2 Geology and Hydrogeology $\ldots \ldots \ldots \ldots \ldots \ldots \ldots \ldots \ldots \ldots$

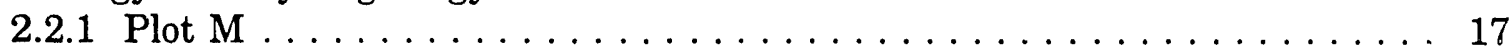

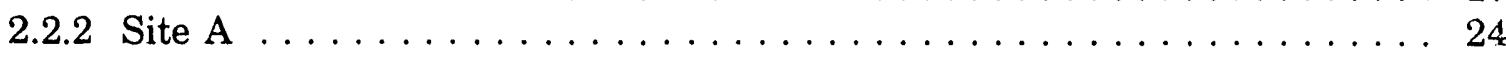

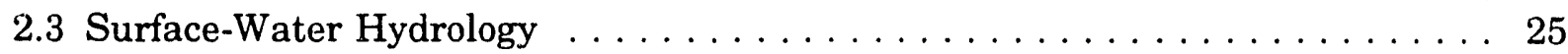

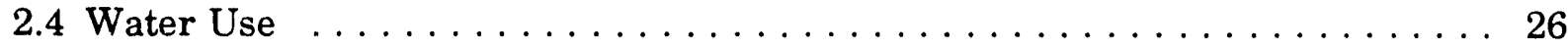

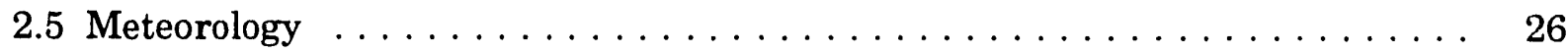

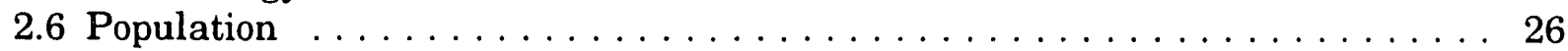

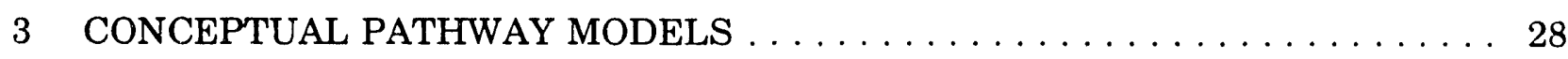

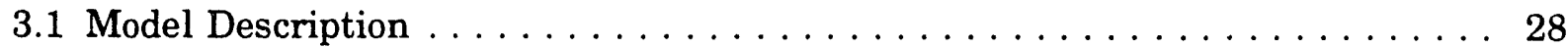

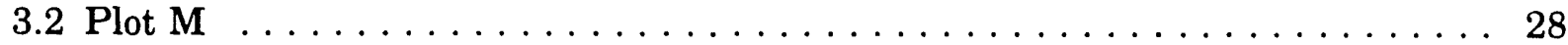

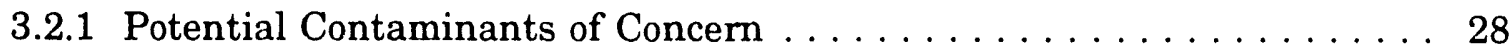

3.2 .2 Release Mechanisms . . . . . . . . . . . . . . . . . . 30

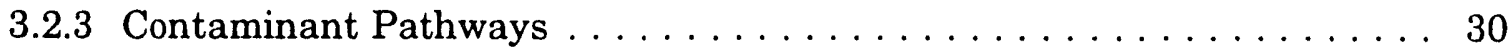

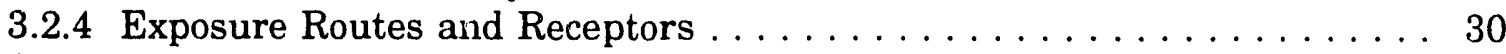

3.3 Site A . . . . . . . . . . . . . . . . . . . . . . . 31

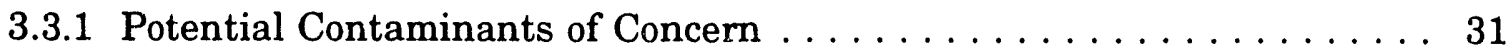

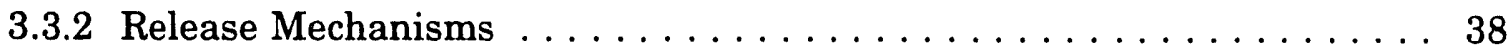

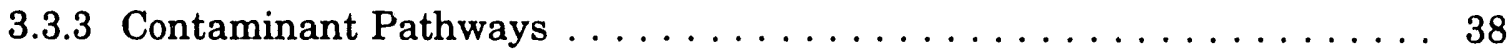

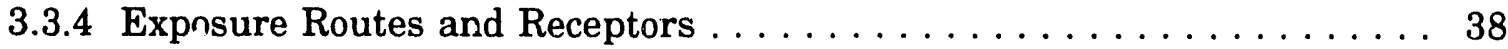

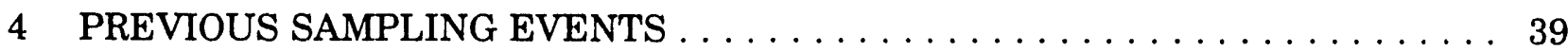

4.1 Plot $M$ and Red Gate Woods Picnic Area . . . . . . . . . . . . . 39

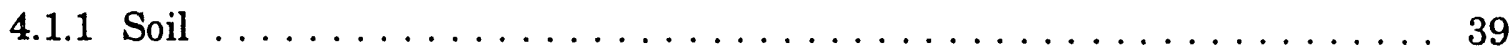

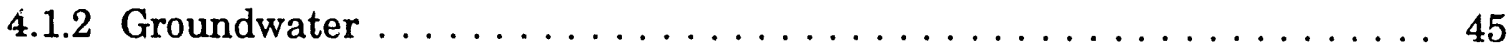

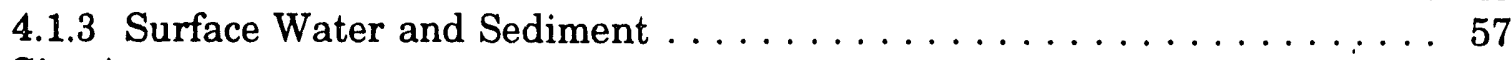

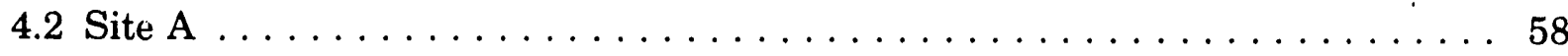

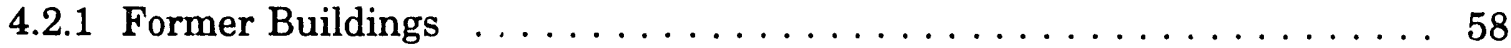

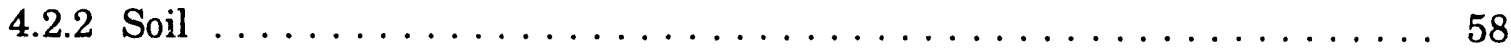

4.2 .3 Groundwater . . . . . . . . . . . . . . . . . . . 64

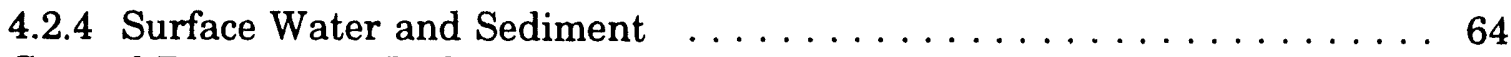

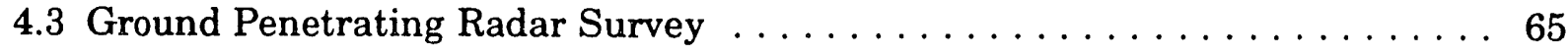




\section{CONTENTS (Cont.)}

5 ESTIMATED ROUTES OF CONTAMINANT TRANSPORT . . . . . . . . . . . 69

5.1 Groundwater Routes for Plot $\mathrm{M} \ldots \ldots \ldots \ldots \ldots$

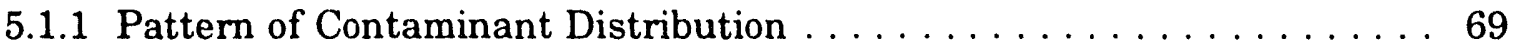

5.1 .2 Previous Pathway Conceptual Models . . . . . . . . . . . . . 71

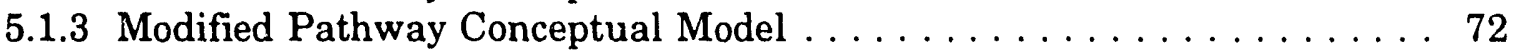

5.2 Transport Routes for Site A . . . . . . . . . . . . . . . . . 74

5.2.1 Patterns of Areas of Elevated Radiation in

Radiological Surveys ....................... 74

5.2.2 Potential Surface Contaminant Sources at Site A . . . . . . . . . . . 75

5.2.3 Potential Surface Contaminant Sources at Suspect

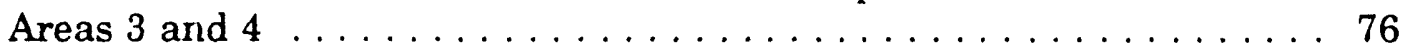

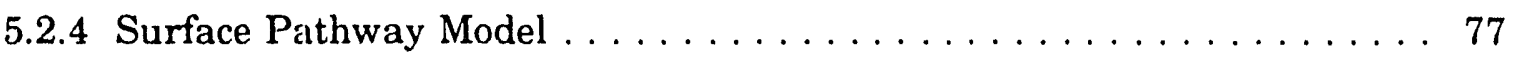

6 EVALUATION OF PHASE 2 WORK PLAN FOR SITE A . . . . . . . . 78

6.1 Previously Identified Areas of Concern $\ldots \ldots \ldots \ldots \ldots \ldots$

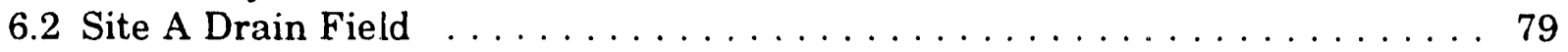

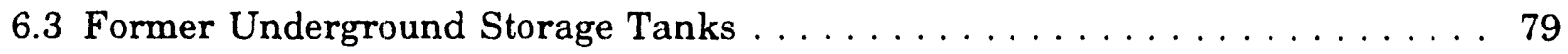

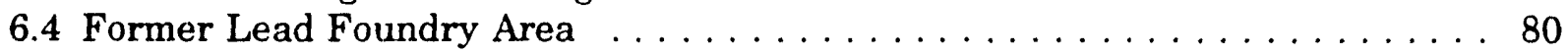

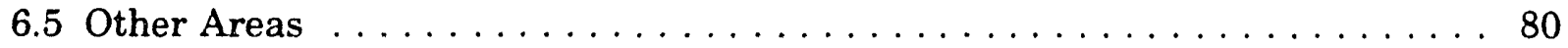

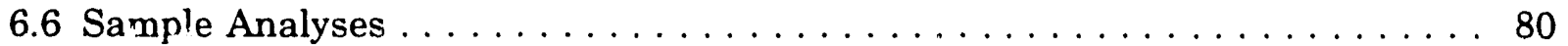

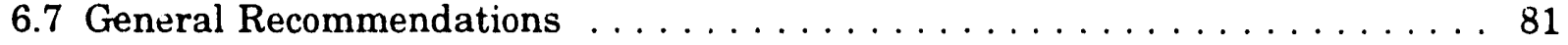

7 PRELIMINARY IDENTIFICATION OF APPLICABLE OR

RELEVANT AND APPROPRIATE REQUIREMENTS AND

TO-BE-CONSIDERED CRITERIA $\ldots \ldots \ldots \ldots \ldots \ldots$

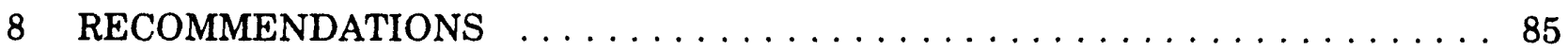

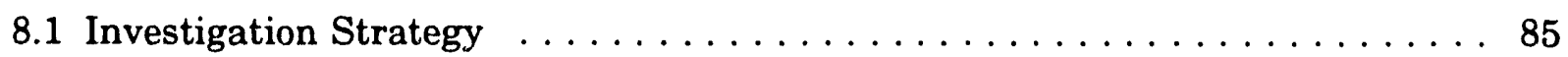

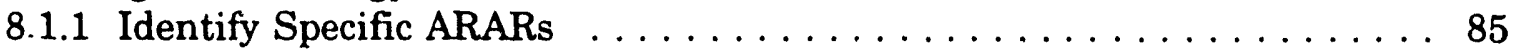

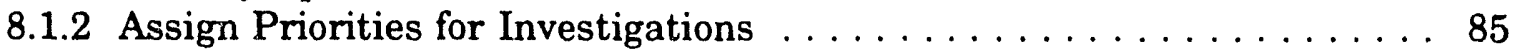

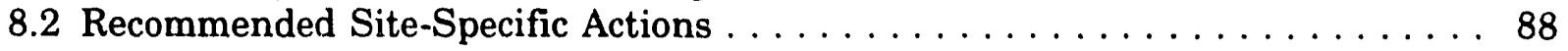

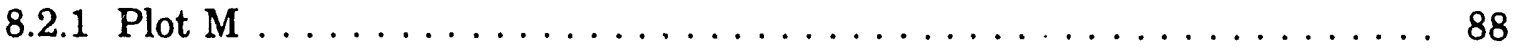

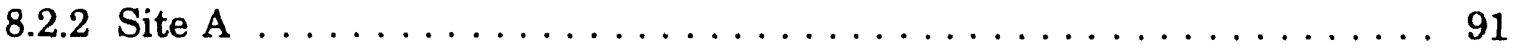

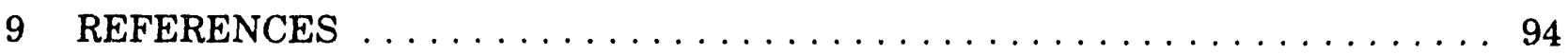

10 BIBLIOGRAPHY FOR SECTION $2.1 \ldots \ldots \ldots \ldots \ldots$

APPENDIX A: Memorandum on Radioactive Waste Disposal at

Argonne National Laboratory, May 6, 1948 . . . . . . . . . . . . . 101

APPENDIX B: Preliminary Identification of Applicable or

Relevant and Appropriate Requirements and

To-Be-Considered Criteria 


\section{CONTENTS (Cont.)}

APPENDIX C: Well Abandonment Prncedures $\ldots \ldots \ldots \ldots \ldots \ldots \ldots$

\section{TABLES}

1.2 Chronology for Plot $\mathbf{M} \ldots \ldots \ldots \ldots \ldots \ldots \ldots \ldots$

3.1 Potential Contaminants at Site $\mathrm{A}$ and Suspect Areas $\ldots \ldots \ldots \ldots$

4.1 Major Environmental Studies of Site $A$ and Plot $M \ldots \ldots \ldots$

4.2 Extent of Tritiated-Water Plume Centered under Plot $\mathrm{M}$

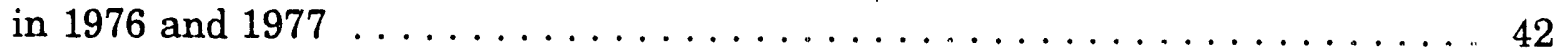

4.3 Extent of Tritiated-Water Plume Centered under Plot M

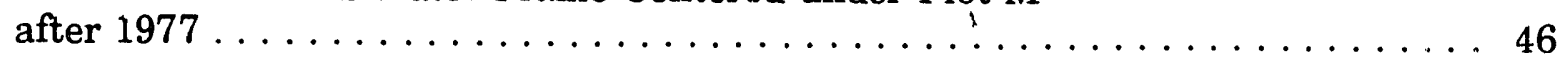

4.4 Background Exposure Rates and Levels of Gamma-Emitting Radionuclides in Surface Soil near Site A . . . . . . . . . . . . . . 63

5.1 Tritiated Groundwater Pathways for Plot M Proposed in Previous Models and in This Report . . . . . . . . . . . . . . . . . . . 73

8.1 Relative Priorities for Various Sites on Site $\mathbf{A}$ and Plot $\mathbf{M} \ldots \ldots 6$

\section{FIGURES}

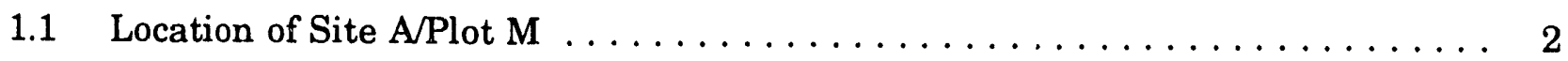

1.2 Site Map of Site $\mathrm{A}$ and $\mathrm{Plot} \mathbf{M} \ldots \ldots \ldots \ldots \ldots$

1.3 Facility Map of Site $\mathbf{A} \ldots \ldots \ldots \ldots \ldots \ldots \ldots \ldots \ldots \ldots$

1.4 Architectural Design of the Concrete Cap for Plot $\mathrm{M}$ - Detail

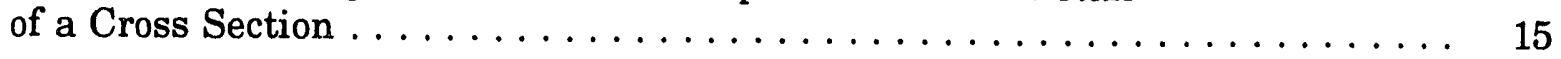

1.5 Architectural Design of the Concrete Cap for Plot M - Plan View . . . . . . 16

2.1 Topographic Map of Site A and Plot $\mathbf{M} \ldots \ldots \ldots \ldots \ldots$

2.2 Topographic Map of Plot $\mathbf{M} \ldots \ldots \ldots \ldots \ldots \ldots \ldots$

2.3 Topographic Map of Site A . . . . . . . . . . . . . . . . . 20 


\section{FIGURES (Cont.)}

2.4 Geologic Cross Section near Plot $\mathrm{M} \ldots \ldots \ldots \ldots \ldots \ldots \ldots$

2.5 Recessional Moraines in the Chicago Area ................. 23

2.6 Topography of Bedrock Surface in Red Gate Woods Picnic Area . . . . . . . . . . 24

2.7 Water Supply Wells near Site A and Plot M in Palos Forest Preserve . . . . . . 27

3.1 Conceptual Pathway Model for Plot $\mathrm{M} \ldots \ldots \ldots \ldots$

3.2 Conceptual Pathway Model for the Underground Storage Tanks and

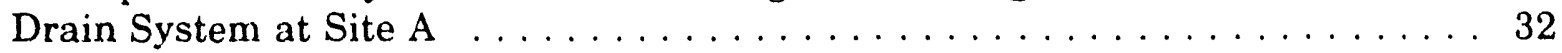

3.3 Conceptual Pathway Model for the Buried Reactor at Site A . . . . . . . . . 33

3.4 Conceptual Pathway Model for Suspect Areas 5 and 6 and the Former

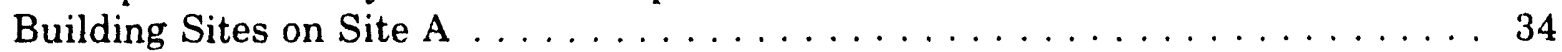

3.5 Conceptual Pathway Model for the Drain Field Northeast of Site A . . . . . . 35

4.1 Boring Locations at Plot $\mathrm{M} \ldots \ldots \ldots \ldots \ldots \ldots$

4.2 Extent of the Tritium Plume in Glacial Tills under Plot $\mathrm{M}$

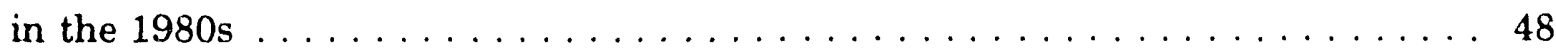

4.3 Extent of the Tritium Plume in Glacial Tills about $200 \mathrm{ft}$ North of the Northern Boundary of Plot M in the Early 1980s

4.4 Average Quarterly Data on Tritium Concentrations in Groundwater from

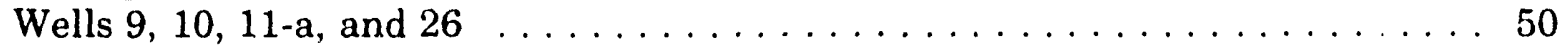

4.5 Average Quarterly Data on Tritium Concentrations in Groundwater from

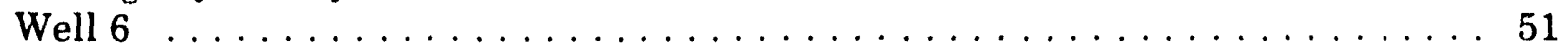

4.6 Average Quarterly Data on Tritium Concentrations in Groundwater from

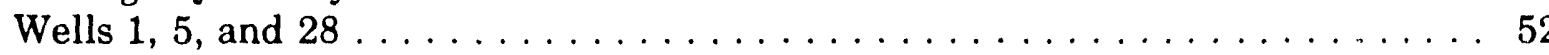

4.7 Average Quarterly Data on Tritium Concentrations in Groundwater from

Well 4

4.8 Average Quarterly Data on Tritium Concentrations in Groundwater from

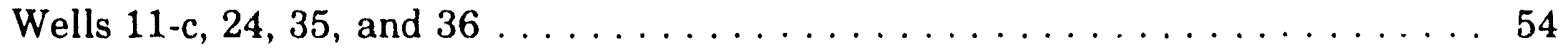

4.9 Extent of the Tritium Plume in the Bedrock Aquifer near Plot M . . . . . . 55

4.10 Sampling Locations for Surface Water and Sediment near Plot M . . . . . 56 


\section{FIGURES (Cont.)}

4.11 Soil Sampling Locations at Site A from 1976 to $1978 \ldots \ldots \ldots \ldots$. . . . . . 59

4.12 Locations of Soil Borings, Dolomite Groundwater Well (DH-1), and Buried Reactor Shield at Site A . . . . . . . . . . . . . . 60

4.13 Soil Sampling Locations at Site A in $1990 \ldots \ldots \ldots \ldots \ldots \ldots \ldots \ldots \ldots$

4.14 Areas Sur reyed by GPR near Site A in $1991 \ldots \ldots \ldots \ldots 6 \ldots \ldots \ldots 6 \ldots$

4.15 Disturbed Areas as Identified by GPR in Suspect Areas 3 and $4 \ldots \ldots \ldots \ldots 7$

5.1 Extent of Tritium Plume in Glacial Tills under Red Gate Woods Stream . . . . . 70

5.2 Groundwater Potential Contours for the Perched Aquifer near Plot M

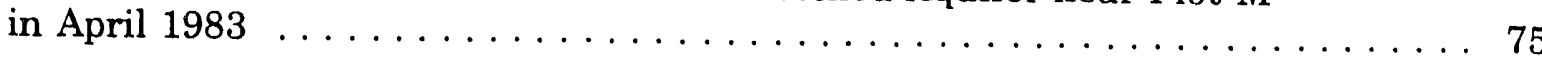




\section{NOTATION}

\section{ACRONYMS, INITIALISMS, AND ABBREVIATIONS}

$\begin{array}{ll}\text { AEC } & \text { Atomic Energy Commission } \\ \text { ANL } & \text { Argonne National Laboratory } \\ \text { ARAR } & \text { applicable or relevant and appropriate regulation } \\ \text { D\&D } & \text { decontamination and decommissioning } \\ \text { DOE } & \text { U.S. Department of Energy } \\ \text { EPA } & \text { U.S. Environmental Protection Agency } \\ \text { GPR } & \text { ground penetrating radar } \\ \text { IDNS } & \text { Illinois Department of Nuclear Safety } \\ \text { ORAU } & \text { Oak Ridge Associated Universities } \\ \text { ORISE } & \text { Oak Ridge Institute for Science and Education } \\ \text { ORNL } & \text { Oak Ridge National Laboratory } \\ \text { PCB } & \text { polychlorinated biphenyl } \\ \text { PVC } & \text { polyvinyl chloride } \\ \text { SVOC } & \text { semivolatile organic compound } \\ \text { TBC } & \text { to be considered } \\ \text { TCL } & \text { Target Compound List } \\ \text { USGS } & \text { U.S. Geological Survey } \\ \text { UST } & \text { underground storage tank } \\ \text { VOC } & \text { volatile organic compound }\end{array}$

\section{UNITS OF MEASURE}

$\begin{array}{llll}\mathrm{cm}^{2} & \text { square centimeter(s) } & \mathrm{m} & \text { meter(s) } \\ { }^{\circ} \mathrm{F} & \text { degree(s) Fahrenheit } & \mu \mathrm{R} & \text { microroentgen(s) } \\ \mathrm{dpm} & \text { disintegration(s) per minute } & \mathrm{mg} & \text { milligram(s) } \\ \mathrm{ft} & \text { foot (feet) } & \mathrm{mi} & \text { mile(s) } \\ \mathrm{g} & \text { gram(s) } & \mathrm{mR} & \text { milliroentgen(s) } \\ \mathrm{gal} & \text { gallon(s) } & \mathrm{mrem} & \operatorname{millirem}(\mathrm{s}) \\ \mathrm{h} & \text { hour(s) } & \mathrm{nCi} & \operatorname{nanocurie}(\mathrm{s}) \\ \mathrm{ha} & \text { hectare(s) } & \mathrm{ng} & \operatorname{nanogram}(\mathrm{s}) \\ \mathrm{in} & \text { inch(es) } & \mathrm{pCi} & \operatorname{picocurie}(\mathrm{s}) \\ \mathrm{kg} & \text { kilogram(s) } & \mathrm{ppb} & \operatorname{part}(\mathrm{s}) \text { per billion } \\ \mathrm{kW} & \text { kilowatt(s) } & \mathrm{R} & \text { roentgen(s) } \\ \mathrm{lb} & \text { pound(s) } & \mathrm{s} & \text { second(s) } \\ \mathrm{L} & \text { liter(s) } & & \end{array}$




\title{
ENVIRONMENTAL REVIEW FOR SITE A/PLOT M, PALOS FOREST PRESERVE, COOK COUNTY, ILLINOIS
}

\author{
by \\ R.P. Biang, C.R. Yuen, H.I. Avci, and R. Haffenden
}

1 INTRODUCTION

This report is an environmental review of two sites known as Site A and Plot M, which are located in the Palos Forest Preserve of the Forest Preserve District of Cook County, approximately $20 \mathrm{mi}$ southwest of downtown Chicago and about $3 \mathrm{mi}$ east of the current site of Argonne National Laboratory (ANL) (Figure 1.1). Figure 1.2 shows an enlarged map of the area around the sites. Site A covers about 19 acres, and Plot M covers about 1 acre.

This document consists of the following sections: a review of the site history and environment, a description of the conceptual pathway models for both Site A and Plot M and a brief discussion of previous sampling events, a discussion of possible transport pathways, an evaluation of the Phase 2 Work Plan for Site A, a review of the applicable or relevant and appropriate regulations (ARARs), and recommendations for future study. The recommendations are based on an evaluation of previously collected data. Where data were sufficient, a geologic conceptual model was developed. If data were not sufficient to develop a model, recommendations for data collection are made. A new base map was developed for the site by using the base survey conducted in the 1940s, aerial photographs dating back to 1948 , and site visits.

\subsection{OBJECTIVES}

The overall objective of this review is to provide the Chicago Operations Office of the U.S. Department of Energy (DOE) with information that clarifies priorities for the continuing characterization of Site A/Plot M. This document is part of an overall site review whose objective is to identify investigation activities that should be added to a characterization plan that is currently being formulated. tasks:

ANL was contracted by DOE-Chicago Operations Office to perform the following

- Review historical records and develop a summary of known activities during site operations. Discuss past activities and the probable presence of any hazardous materials as a result of thcse activities. 


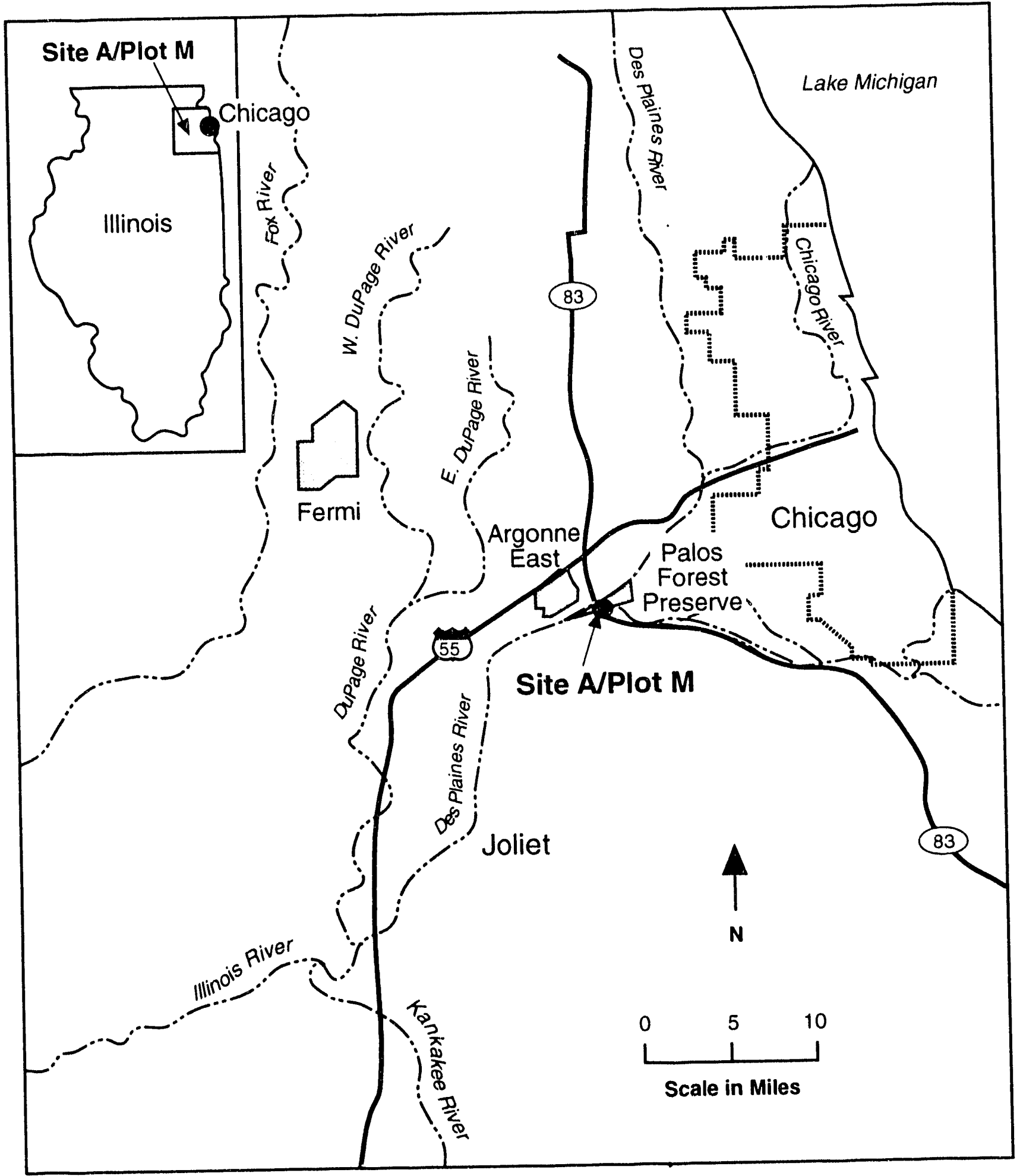

FIGURE 1.1 Location of Site A/Plot M 


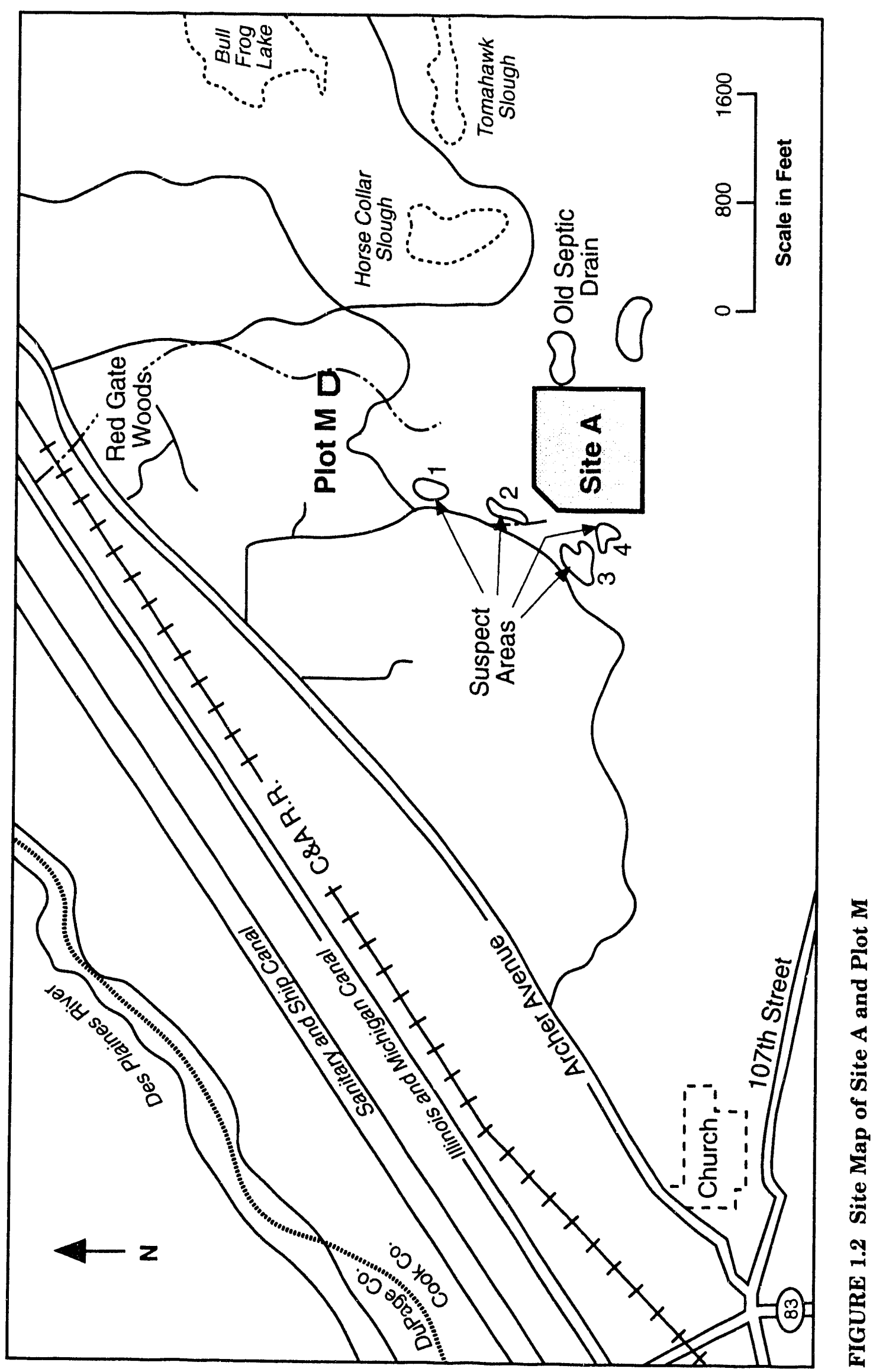


- Analyze the existing data acquired at Site A/Plot M during (1) the regular surveillance and monitoring program performed by the ANL Environment and Waste Management Program and (2) the Phase 1 radiological survey performed by Oak Ridge Associated Universities (ORAU). Analyze the data with respect to known and suspected releases to the environment from past activities. On the basis of this review, determine whether accurate conceptual geologic and hydrogeologic models of both sites have been developed and, if not, prepare conceptual models that are consistent with known information and possible transport pathways. If adequate information is not available, make recommendations for further investigation.

- Review and comment on the Phase 2 Work Plan prepared by ORAU (March 1991). Identify any additional data needs $n$ t included in the Phase 2 Work Plan.

- Identify all federal and state ARARs for the known contaminants and media. Specific ARARs will help focus future data gathering efforts and will help develop remedial alternatives.

- Evaluate the existing monitoring wells to determine whether they are capable of providing samples representative of the groundwater quality for the aquifers of concern. Focus the review mainly on well construction and the sampling program. Review well construction details and assess the need to properly abandon any existing wells that are not useful, that are not constructed properly, or that pose a threat to the public or to groundwater.

This report summarizes the results of the above tasks. General recommendations regarding additional investigation are made in the last section. These recommendations are not intended to provide the details, such as descriptions of specific investigative methods, that a sampling and analysis plan provides. Rather, they present general sampling guidance that can be employed to prepare such a plan.

\subsection{SITE HISTORY*}

In July 1942, the U.S. Army Corps of Engineers leased 415 ha (1,025 acres) of land from the Forest Preserve District of Cook County in Palos Forest Preserve. The land was needed for highly secret research and development work under the Manhattan Project (the name given to the U.S. effort during World War II to develop the first atomic bomb). The project was conducted in many universities and research centers around the United States. The institution working on this project in the Chicago area was called the Metallurgical

* The historical information presented in this section was gathered from the sources listed in the bibliography in Section 10. 
Laboratory, which was managed by the University of Chicago. This "laboratory" was physically located in several buildings on and near the university campus. The Palos Park site was acquired as a place to build the first controlled, self-sustaining nuclear reactor and carry out research invoiving the reactor. Because of its seclusion and distance from the crowded Chicago metropolitan area, the site was thought to be an ideal location. However, because of time pressures, Enrico Fermi and his colleagues actually built the first reactor on the University of Chicago campus (in an abandoned squash court under the west stands of Stagg Field) in November 1942. The reactor was named Chicago Pile-1 (CP-1), and it achieved the first controlled, self-sustaining nuclear chain reaction on December 2, 1942.

\subsubsection{Site A}

Starting on February 28, 1943, CP-1 was dismantled and moved to Site A, where it was reconstructed. Renamed CP-2, it resumed operation on March 20, 1943. CP-2 was constructed with graphite blocks and natural uranium embedded in graphite blocks. The reactor had a concrete shield to reduce the radiation levels around it. The overall dimensions of the reactor, including the shield, were $30 \mathrm{ft} \times 32 \mathrm{ft} \times 25.5 \mathrm{ft}$ high. It was cooled by natural-convection ambient air and usually operated at around $2 \mathrm{~kW}$ thermal power. (See ANL 1950a and Glasstone 1955 for a more complete description of CP-2.)

Construction began in September 1943 on a new reactor at Site A. This second reactor, named CP-3, started operation on May 15, 1944. As with CP-2, CP-3 was fueled with natural uranium, but heavy water was used to cool the reactor (as opposed to air cooling in CP-2) and to slow down the energetic neutrons (as opposed to graphite in CP-2). The reactor consisted of an aluminum tank, $6 \mathrm{ft}$ in diameter and $8 \mathrm{ft}, 10 \mathrm{in}$. high, which was filled with approximately 6.5 tons of heavy water. In this tank were suspended 120 uranium metal rods with aluminum cladding. The rods were $1.1 \mathrm{in}$. in diameter and $6 \mathrm{ft}$ long. To remove the heat generated by the fission process, the heavy water was circulated through a heat exchanger.

On the bottom and sides, the reactor vessel was surrounded by a 2 -ft-thick layer of graphite. The graphite reflected some of the escaping neutrons back into the vessel. A 4-in.-thick thermal shield made of a lead-cadmium alloy surrounded the graphite reflector and fit snugly against an 8-ft-thick concrete biological shield that encased the entire reactor. The thermal shield was cooled by water flowing through copper tubes. The concrete biological shield was octagonal, and its overall external dimensions were $26 \mathrm{ft}$ across and $14 \mathrm{ft}$ high. A more complete description of CP-3 and the experimental setups around the reactor is provided in ANL 1950b and in Glasstone 1955.

The top of the reactor was shielded by a thin layer of cadmium, $1 \mathrm{ft}$ of lead, and a 4-ft-thick cover consisting of alternate layers of steel and compressed wood fiber (in the form of removable blocks). To maintain and fuel the reactor, these layers of shielding materials were removed. The reactor was usually operated at $300 \mathrm{~kW}$ thermal power. 
CP-3 was dismantled in January 1950 because of suspected corrosion of the aluminum cladding of some of the fuel rods, and the natural uranium fuel was replaced with highly enriched uranium. The new fuel rods, which contained a total of $4.5 \mathrm{~kg}$ of highly enriched uranium, were made of a $2 \%$ uranium- $98 \%$ aluminum alloy. Each fuel rod was 0.85 in. in diameter and $5.5 \mathrm{ft}$ long (Tyrell et al. 1961). The new reactor was named CP-3'. It went critical (became self-sustaining) in May 1950.

Both reactors were used strictly for research purposes. Many types of research were conducted, including studies in reactor physics, experiments related to the operation and control of nuclear reactors, experiments in producing plutonium-239 in the reactors, neutron cross section measurements for various materials, experiments in shielding and radiation protection, and studies to identify the properties of fission products. The information obtained was used in the dęign and operation of the pilot plant built at Oak Ridge and the actual production reactors built at Hanford, near Richland, Washington (graphite reactors) and at Savannah River, near Aiken, South Carolina (heavy water reactors). The reactors were also used to irradiate various specimens for transmutation studies and biological experiments. Many new radioisotopes were produced and analyzed. Materials from other Metallurgical Laboratory sites and universities were brought in for irradiation and were returned to their place of origin for analysis. The reactors were also used to train the operators of the production reactors.

Initially, almost all the research conducted at Site A was related to the two reactors. The reactors continued to be the central focus of research at the site, but in later years, additional research activities were undertaken that were related to development of other types of nuclear reactors and to the separation of plutonium-239 from irradiated fuel. Two new buildings were added on the south side of the site to house facilities for experiments with liquid sodium in support of liquid-metal-cooled fast breeder reactors (Laboratories $\mathrm{K}$ and $\mathrm{L}$ ). Laboratory $\mathrm{L}$ was also used to study the separation of fission products and actinides from irradiated fuel. Figure 1.3 shows schematically the locations of buildings at the site during its years of operation. The CP-2 reactor was housed in the southern part of Building A, and CP-3 (which became CP-3' in 1950) was housed in Building B. The north half of Building A, as well as Buildings $C$ and $D$, contained offices, small laboratories, machine shops, a woodworking shop that was also used to machine graphite, and a library. Building $\mathrm{H}$ (called Treater House) was used as a vault for storage of valuable materials. Storage sheds and huts along the southern border of the site and in the northwest corner were built in the late 1940s or early 1950s to store various equipment and materials. The two quonset huts (Buildings $Q$ and $R$ ) and the garage to the north of the site (Building $T$ ) were also added during those years. Many of the workers stayed at the site and lived at the dormitory (Building G). The dog shelter (Building $\mathrm{X}$ ) housed the dogs that were used for research by scientists who worked mostly at the other Metallurgical Laboratory sites in Chicago. In addition, a small lead foundry was located near Laboratories $\mathrm{K}$ and $\mathrm{L}$; it was used to cast the lead blocks used for shielding around the two reactors and in the laboratories. The foundry consisted of a kettle on an open-pit fire, which was used to melt the lead, and molding, which was used to form the lead blocks in the desired shapes. The foundry was enclosed in a wooden shack. 


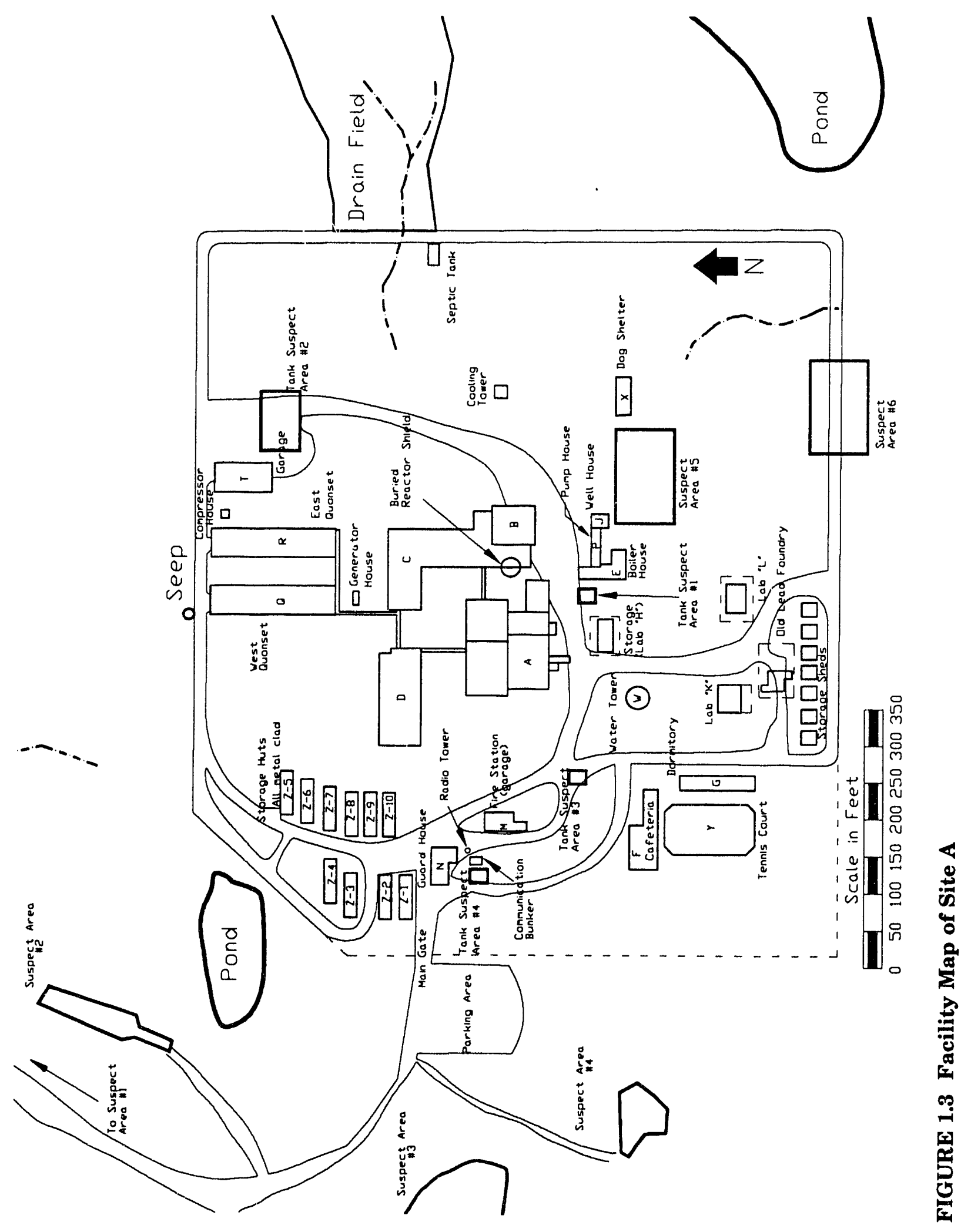


In 1947, the present site of ANL was obtained, and by 1949 the first permanent buildings at that location were completed. As the new facilities were finished, the programs were transferred from Site $A$ to the new site. The move was essentially complete in May 1954, when CP-2 and CP-3' were shut down.

The decontamination of buildings at Site $\mathrm{A}$ and the decontamination and decommissioning (D\&D) of the two reactors (CP-2 and CP-3') are explained in Lonergan (1958). Tyrell et al. (1961) also provide a detailed account of the D\&D of the reactors. According to Lonergan (1958), all buildings and equipment at Site A were decontaminated in 1954 and 1955. All fuel from CP-2 and CP-3' was removed and shipped in 1954 and 1955. The CP-2 fuel was used at ANL-East, and the CP-3' fuel was reprocessed in Idaho. The reactor shells were demolished and buried at the site in November 1956.

Buildings $\mathrm{H}, \mathrm{K}$, and $\mathrm{L}$, along with the Doghouse, Quonset Huts, Dormitory, and Cafeteria, were decontaminated by December 30, 1955. In this group of buildings, Building $\mathrm{L}$ was the most heavily contaminated and most difficult to clean. It was a small, concrete-block building ( $20 \mathrm{ft} \times 40 \mathrm{ft} \times 30 \mathrm{ft}$ high), which was lined with stainless steel paneling and which housed large extraction columns. This building was contaminated with plutonium on the interior, with levels ranging from 100 disintegrations per minute $(\mathrm{dpm})$ to more than 12 million $\mathrm{dpm} / 100 \mathrm{~cm}^{2}$ of loose alpha activity.

\subsubsection{D\&D of CP-2*}

All removable housings for CP-2 were stripped off during April 1955: 24,000 board-ft of lumber in the form of six-by-sixes was removed from the top of CP-2, surveyed, and disposed of as suspect material. Next, 4,175 lead bricks were removed from the top of CP-2. After these lead bricks were surveyed individually and cleaned, they were dispersed for further use in various shops and laboratories at the current ANL-East site.

Some of the graphite and fuel materials from CP-2 were remachined and reconstructed in a building housing various experiments of the International School of Nuclear Science and Engineering at ANL-East.

The levels of contamination encountered on the top of CP-2 ranged from 5,000 to $10,000 \mathrm{dpm}$-alpha/100 $\mathrm{cm}^{2}$. During dismantling of the reactor, the workers wore supply-air masks.

To minimize airborne contamination, cardboard cartons were laid down as a floor over each layer of graphite blocks in the reactor, except for over the small area being dismantled. This covering successfully prevented large amounts of activity from becoming airborne.

\footnotetext{
* This section is based on information provided in Lonergan (1958).
} 
A fuel-recovery hood was used in the removal of the fuel from the stringers (graphite blocks with fuel in them). The stringers containing the fuel were placed in the fuel recovery hood through an aperture at one end. Working through glove ports, an operator inverted each stringer and knocked the fuel out; the fuel was then collected in cans located below funnels in the bottom of the hood.

Once the fuel had been removed, the graphite stringers were placed in a bin, which was then surveyed, sealed, and taken to the active storage area (except for the graphite that was used by the International School of Nuclear Science and Engineering, as mentioned above).

The removal of uranium oxide and metal from CP-2 took about nine weeks (from August 29, 1955, through November 1, 1955). One layer of graphite blanks and one layer of stringers containing fuel were removed daily by means of the procedure described above.

After all the fuel and graphite had been removed from the shield of CP-2, the shield and walls in room A-16 (the room where the reactor was located) were washed down with trisodium phosphate and then vacuum rinsed. The final activity level in this room, considered fixed on the surface (nonremovable), ranged from 100 to $200 \mathrm{dpm}$-alpha/100 $\mathrm{cm}^{2}$, with one spot of $400 \mathrm{dpm}$-alpha/ $100 \mathrm{~cm}^{2}$ and other spots ranging from 0.5 to $0.7 \mathrm{mR} / \mathrm{h}$ of betagamma radiation at 1 in.

On November 1, 1955, the fuel removal of CP-2 was considered complete. The next three months were spent monitoring operations involving the shipment or disposal of the material removed. Table 1.1 summarizes the items removed from CP-2.

\subsubsection{CP-3' Decontamination and Fuel Recovery}

The following description of CP-3' decontamination and fuel recovery operations is based on Tyrell et al. (1961), Section 2.

After an initial cleanup of loose activity around the reactor by vacuuming, several tons of cold-rolled-steel/masonite sandwich blocks (W-blocks), which had been used as shielding on the top of the reactor, were removed. Each of the 217 blocks was surveyed, but few, if any, were found to be contaminated. They were taken to the central Decontamination Shop (at ANL-East), where they were used to construct a cave (an enclosure for storage of radioactive materials).

The I-beams, reactor tank lid, and various connecting lines were removed from the top of the reactor to allow the fuel rods to be removed. This material was surveyed; some was removed to the waste storage area. Some of it was later put back into the reactor shield (see below).

The fuel was sent to Idaho for reprocessing. The only shipping casks available accommodated fuel only 23 in. long. It was necessary, therefore, to cut the fuel into smaller 
pieces. To do this, two concrete shielding walls, $7 \mathrm{ft}$ high and $18 \mathrm{in}$. thick, were constructed about $10 \mathrm{ft}$ apart near the reactor. One of the walls contained a 6-in. lead-glass window. A hydraulic shear was set up in the space between the walls. Fuel elements (with activity levels of about $200 \mathrm{R} / \mathrm{h}$ ) were drawn up out of the reactor, one at a time, through a hollow, vertical, cylindrical, 2-ton coffin. Each fuel element was lifted by a cable that had been lowered to the top of the reactor through the coffin. The cable was snap-connected to an eye bolt on the top of each fuel rod. The reactor building cranis was used to position the coffin over the shear, and the element was cut into pieces. Ball-joint manipulators were then used to place the pieces in stainless steel liners, which, in turn, were placed in the shielded shipping containers.
TABLE 1.1 Material Removed from CP-2

\begin{tabular}{ll}
\hline \multicolumn{1}{c}{ Material } & \multicolumn{1}{c}{ Amount } \\
\hline $\mathrm{UO}_{2}$ and $\mathrm{U}_{3} \mathrm{O}_{8}$ & $26,600 \mathrm{~kg}$ \\
Uranium metal $_{\text {Graphite blanks (solid) }}$ & $9,600 \mathrm{~kg}$ \\
Graphite stringers & 210 tons \\
Lead bricks & 72 tons \\
Paraffin blocks & 50 tons \\
Lumber & 1.5 tons \\
\hline
\end{tabular}

a Graphite blocks that were embedded with fuel while in the reactor. After the blocks were removed from the reactor, the fuel was taken out, and the graphite was disposed of as dry active waste.

Source: Tyrell et al. (1961).

After all the fuel had been removed, the various experimental holes in the reactor were decontaminated by vacuuming and washing with detergents; they were then filled with concrete. Auxiliary equipment, particularly the gas recombiner, was removed, and the room was decontaminated. Some spots had activities as high as $1 \mathrm{R} / \mathrm{h}$, but the area was cleaned until no areas remained with activities in excess of $200 \mathrm{mR} / \mathrm{h}$. Vacuuming and detergent washing were sufficient for most areas, but some spots had to be removed with a jackhammer.

During all of these operations, the air was monitored continuously, and it was not found necessary to use respirators during any of the operations, not even during the fuel removal phase of the work.

When the fuel had all been removed and the reactor had been reasonably decontaminated, the top was replaced on the reactor and the cavity in the shield was filled with concrete, burying the tank. Many pieces of contaminated or suspect equipment were thrown into the cavity as it was being filled with the concrete.

\subsubsection{Demolition and Burial of CP.2 Shield and Burial of CP-3' Remains}

The following description of the activities leading up to demolition and burial of the CP-2 shield and burial of CP-3' remains (after decontamination and fuel recovery, as described above) is extracted from Lonergan (1958).

The building that housed CP-2 was located approximately $100 \mathrm{ft}$ from the one that housed CP- $3^{\prime}$. The reactors themselves were approximately $180 \mathrm{ft}$ apart. 
After decontamination was complete, the wrecking and salvage crews began to remove power, drain, and sewage lines. This work was done by non-Argonne personnel under the supervision of a representative of the Chicago Operations Office of the Atomic Energy Commission (AEC). However, continuous radiation safety coverage was supplied by Argonne personnel during this phase of the restoration program.

The buildings that housed the reactors were demolished, and the refuse was saved to fill the excavation. An excavation approximately $100 \mathrm{ft}$ across and $50 \mathrm{ft}$ deep was prepared between the two reactors. The approximately 800-ton, concrete-filled, octagonal shell of CP-3' was prepared for burial by excavating around it on three sides, which left it on a pedestal of soil. Workers placed $231 \mathrm{lb}$ of explosives in strategically located borings in the earthen pedestal under the CP-3' pad. The explosives were detonated at 1:30 p.m. on November 3, 1956. The explosion blew the pedestal from under the concrete-filled reactor shell, which tipped as it slid into the excavation and landed bottom up.

The overturned reactor was completely surveyed at the periphery of the excavation, in the pad area, and in the excavation proper. No activity was detected during any of these surveys. One small crack was noted on the bottom of the reinforced pad, which was now exposed. On closer inspection, this crack was found to be approximately $3 \mathrm{in}$. deep at its deepest point. As an extra precautionary measure, the bottom of the reactor shell was entirely covered with approximately 6 in. of grout.

The poured concrete shield of CP-2, the only remaining portion of that reactor, was demolished with a wrecking crane and pushed into the same excavation. The crater containing the remains of CP-2 and CP-3' was then filled, leveled, and landscaped.

\subsubsection{Decommissioning of Site A}

A composite radiation safety report on Site $A$ was prepared and forwarded to the AEC on April 2, 1956 (McKinley 1956). The report provided results of radiation surveys of buildings at Site A as of February 1, 1956. No authors or organizations are listed on the report, and it appears that it was never published. However, because it was submitted to the AEC by ANL, and because some references are made to the report in other correspondence, it seems to have been prepared by ANL. The letter transmitting the report to the AEC referred to it as "the final Radiation Safety Report on Site A" (McKinley 1956).

In that report, the word "surveyed" is defined as follows: "'Surveyed' as used in this report means that all floor areas, horizontal surfaces, and walls up to approximately seven feet have been checked by Radiation Safety Technicians with the instruments at their disposal."

The 1956 survey report states that, except for rooms A-16 and B-1 in Buildings A and $B$ (which are the rooms that housed CP-2 and CP- $3^{\prime}$, respectively), no radioactivity above background was detected in any of the buildings that were surveyed. The radioactivity levels reported for room A-16 were in the range of 0.1 to $0.7 \mathrm{mR} / \mathrm{h}$ of beta-gamma radiation at 1 in. 
and 100 to $400 \mathrm{dpm}$-alpha/100 $\mathrm{cm}^{2}$. In room B-1, $0.1 \mathrm{mR} / \mathrm{h}$ at 1 in. was reported for betagamma radiation. No alpha activity was detected in room B-1. These two rooms were demolished and buried along with the reactor shields and the remains of CP- 3 '.

These buildings were surveyed: laboratories and offices (Buildings C, D, K, and L), Cafeteria (F), Dormitory (G), Treater House (H), Fire House (M), Quonset Huts ( $Q$ and R), and Garage (T), Dog Shelter (X), and Storage Huts (Z-1 through Z-10). The following buildings were not surveyed: Boiler House (E), Cooling Tower (O), Pump House (P), Compressor House (S), Well House (J), Generator House (V), Guard House at Main Entrance $(\mathrm{N})$, and Water Tower (W). The lead foundry was not mentioned in the report; therefore, it is not clear if it was sampled.

During 1956, all the buildings and structures at Site A were demolished. Most of the debris was moved from the site. Negotiations were conducted between the AEC and the Forest Preserve District of Cook County, and arrangements were made for the site to be transferred back to the Forest Preserve District.

\subsubsection{Plot $M$}

Plot $\mathrm{M}$ was the disposal ground for radioactive wastes from Site $\mathrm{A}$ and other Metallurgical Laboratory sites in Chicago from about May 1944 to May 1949. It is located approximately $1,600 \mathrm{ft}$ north of Site A (Figure 1.2). Table 1.2 lists chronologically the main events in the history of Plot M.

The major source of information for Plot $M$ has been an internal ANL memorandum dated May 6, 1948, from C.A. Young, Safety Engineer, to H.L. Hall, Associate Director of ANL, on the subject of radioactive waste disposal. Because of its importance, this memorandum is presented in its original form in Appendix A, even though it is somewhat difficult to read in places. (A retyped version is also included in Appendix A.) Another major source of information for Plot $M$ has been the Weekly Health Physics Survey reports at Site A and other Metallurgical Laboratory sites in Chicago.

Young (1948) states that the disposal of radioactive waste started in February 1944 (item 1 in the memo) and disposal at Plot M started in about May 1944 (item 5). We have not been able to determine where the wastes were disposed of from February to May 1944. It is also not clear what happened to the wastes generated before February 1944 .

The Metallurgical Laboratory operations in the Chicago area started during the summer of 1942. CP-1 started operation in December 1942, and the operations at Site A began in early 1943, with CP-2 coming on line in March 1943. The CP-1 and CP-2 reactors, because of their low power and natural-circulation air cooling, would not have generated much radioactive waste during that time. Since the reactors were new and were of high research interest, any radioactive materials produced in the reactors would have been kept for research and analysis. Any residuals from the research conducted either would have decayed to unmeasurable quantities by now or would have had very small activities initially. 
TABLE 1.2 Chronology for Plot M

\begin{tabular}{|c|c|}
\hline Date & Activity \\
\hline May 1944 & $\begin{array}{l}\text { Burial of dry solid and noncombustible liquid radioactive waste begins at } \\
\text { Plot } M \text { in trenches that are approximately } 3 \mathrm{ft} \text { wide, } 10 \mathrm{ft} \text { long, and } 6 \mathrm{ft} \\
\text { deep. }\end{array}$ \\
\hline September 1945 & $\begin{array}{l}\text { The plot is enclosed with a } 7 \text {-ft-high wire fence. The lower } 18 \text { in. of the } \\
\text { fence is covered with sheet metal to prevent animal intrusion, and the top } \\
\text { is covered with three strands of barbed wire. }\end{array}$ \\
\hline April 1946 & Disposal of active liquids is discontinued. \\
\hline 1948 & $\begin{array}{l}\text { Burial of radioactive wastes in open trenches is discontinued and replaced } \\
\text { by burial in steel bins. }\end{array}$ \\
\hline 1948 & $\begin{array}{l}\text { Environmental monitoring programs around Site } \mathrm{A} \text { and Plot } \mathrm{M} \text { begin. } \\
\text { Original program is very limited but is gradually expanded. }\end{array}$ \\
\hline May 1949 & Steel bins are removed and burial of wastes is discontinued. \\
\hline 1951 & $\begin{array}{l}\text { Discussions begin on methods for releasing Site A and Plot } M \text { to Forest } \\
\text { Preserve District. }\end{array}$ \\
\hline 1956 & Plot $\mathrm{M}$ is covered with concrete cap and dirt. \\
\hline 1956 & Plot $\mathrm{M}$ is returned to Forest Preserve District \\
\hline
\end{tabular}

In item 3, Young (1948) states, "The first material disposed of was a group of ether solutions from cyclotron chemical laboratory. These were burned with a few pieces of contaminated apparatus on the ground, later in an iron kettle, at a spot approximately seven hundred (700) feet west of Building A." Item 8 in the memo also mentions burning liquids in an iron kettle. The location mentioned could be either suspect area 3 or suspect area 4 (Figure 1.3; see also Section 3.3.1.4). These statements raise the possibility that the waste materials that might have been slightly contaminated with radioactive constituents were burned at that location before February 1944. It is also possible that suspect areas 5 and 6 (in the southeast quadrant of the site; Figure 1.3) were used during that time (Section 3.3.1.5).

During the first several years that Plot $M$ was in operation, radioactive materials (both solid and liquid) were placed at the bottom of 6-ft-deep trenches. All solid and noncombustible liquid wastes from Site $A$ and other Metallurgical Laboratory sites in Chicago were buried in Plot M from about May 1944 to April 1946. In April 1946, the disposal of liquid waste was discontinued. Item 22 in the Young (1948) memo states that "Between August 1944 and March 1946 all solutions were left intact in bottles or carboys unless some fractured during or after placement in pits." Therefore, there may still be some liquid waste in intact containers in Plot M. 
The disposal of solid waste directly into the trenches continued until 1948. A variety of materials were disposed of, including chemicals, rubber gloves, shoes, laboratory equipment, animal carcasses, animal excrement, paper, pails, mops, air filters, clothing, catch basin sludge, magnesium chips, and graphite crucibles.

Sufficient soil was used to cover the material to reduce radiation to a few milliroentgens per hour. Additional radioactive material was placed on top of the original material and also covered; this procedure continued until the trench was full. Sometime prior to July 6, 1948 (possibly early in 1948), material was placed in steel bins, which were placed in the trenches and covered with soil. The burial area eventually covered an area $150 \mathrm{ft} \times 140 \mathrm{ft}$. No precise inventory of the buried material was kept, and the early records give little indication of the identity and quantity of the specific radionuclides involved.

Beginning on May 24, 1949, the bins were removed in a search for some missing uranium-235, which was subsequently found. The bins were not reburied but instead were shipped to the present ANL site. After this work was completed on June 10, 1949, burial at Plot $M$ was discontinued, and the area was covered with additional soil and seeded with a grass cover.

Plot $M$ remained in this condition until the spring of 1956 , when an inverted concrete box was constructed to cover the entire burial plot. The concrete sidewalls were $1.5 \mathrm{ft}$ thick and extended $8 \mathrm{ft}$ into the ground. A 1- $\mathrm{ft}$-thick concrete slab was placed over the entire area. The concrete was covered with about $2 \mathrm{ft}$ of soil, grass was seeded, and an inscribed granite marker was placed in the center of Plot $M$. The purpose of the concrete barrier was to prevent people from digging into the waste and to impede the flow of water through the buried radioactive materials. The decision to decommission the plot in this way was made after considering alternative methods, including removing the contents of the burial plot.

Figures 1.4 and 1.5 show part of an architectural drawing of the concrete cap of Plot M. The drawing was prepared in 1955 (see label in Figure 1.4). Because of the poor quality of the drawing, the plan view (Figure 1.5) and detail of a cross section (Figure 1.4) were recreated from the original. The drawing shows the inscribed marker to be in the southwest corner of the plot (Figure 1.5). In reality, the marker was placed and is still located in the center of the plot. 


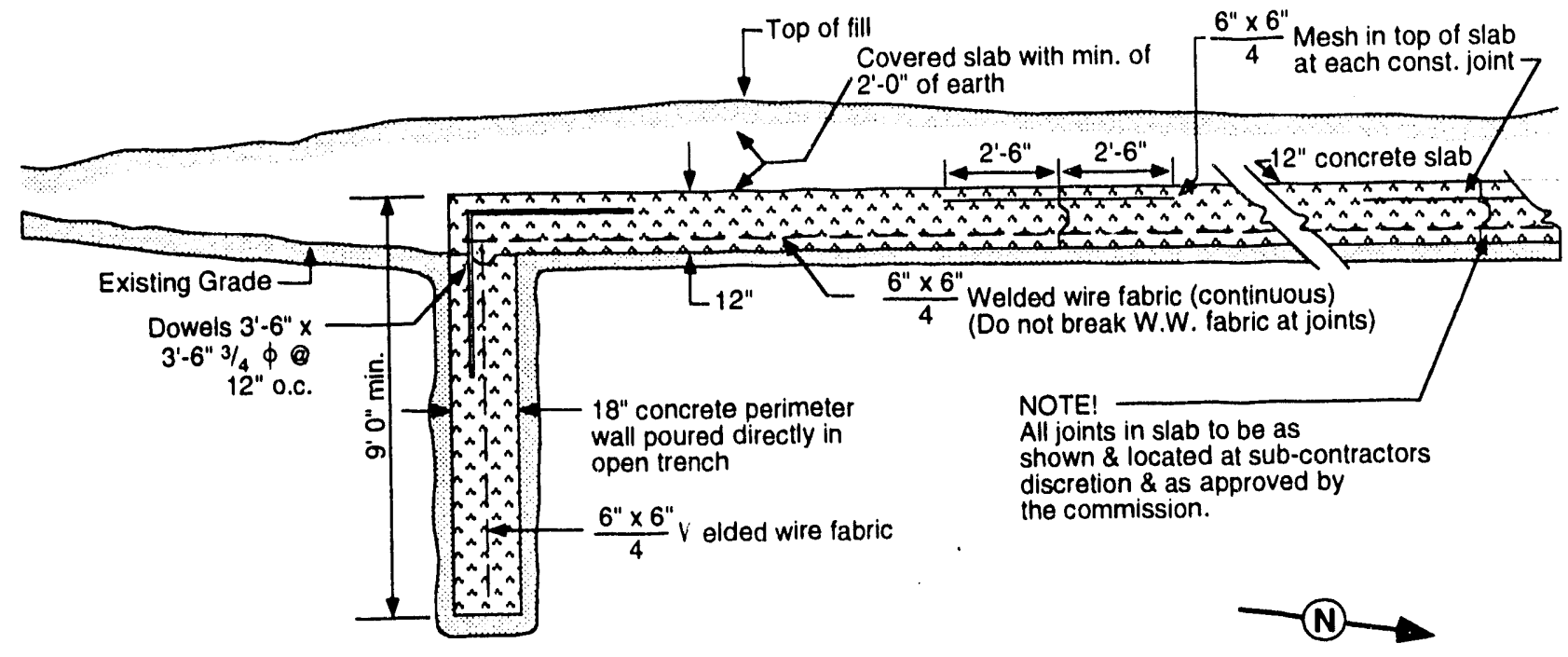

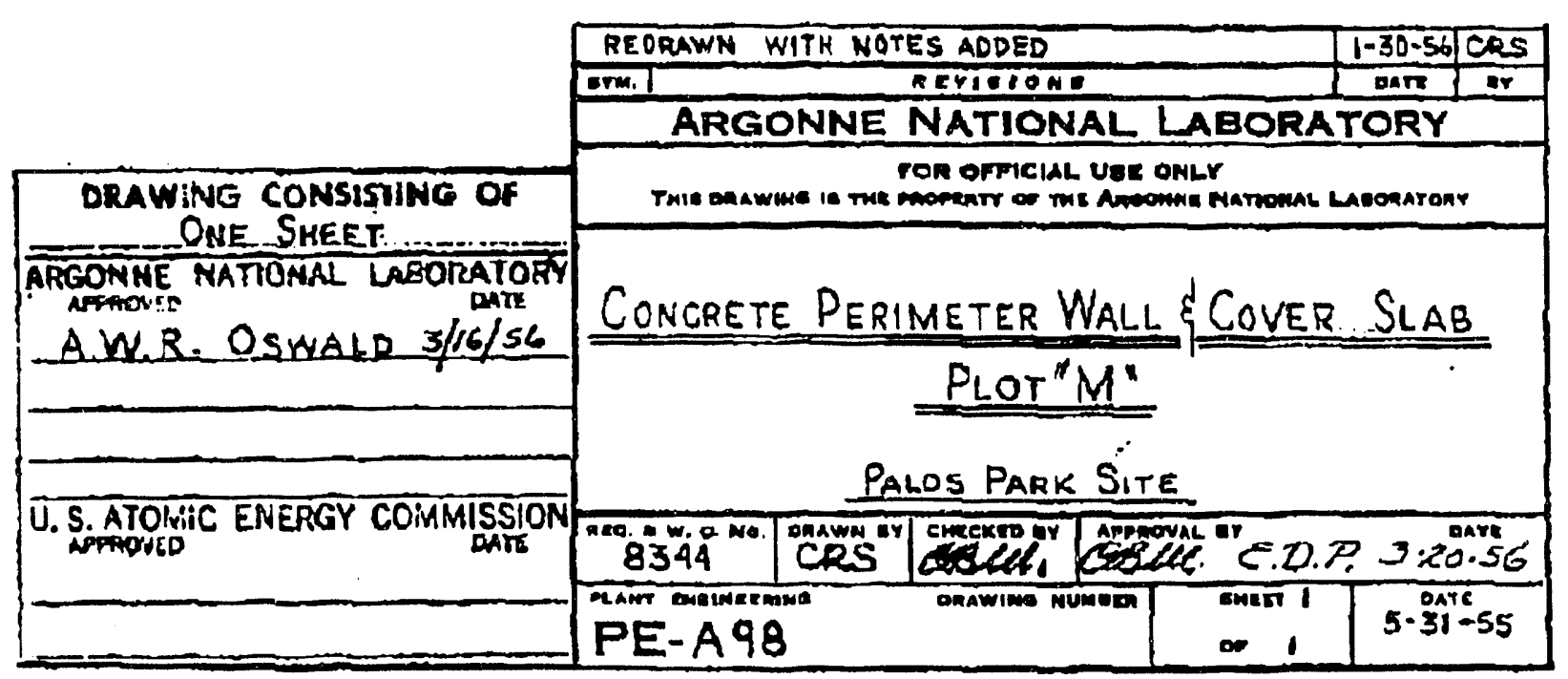

FIGURE 1.4 Architectural Design of the Concrete Cap for Plot M - Detail of a Cross Section (Source: Recreated from the original: ANL Plant Engineering drawing PE-A-98, January 30, 1956; label scanned electronically from original and reproduced without alteration) 


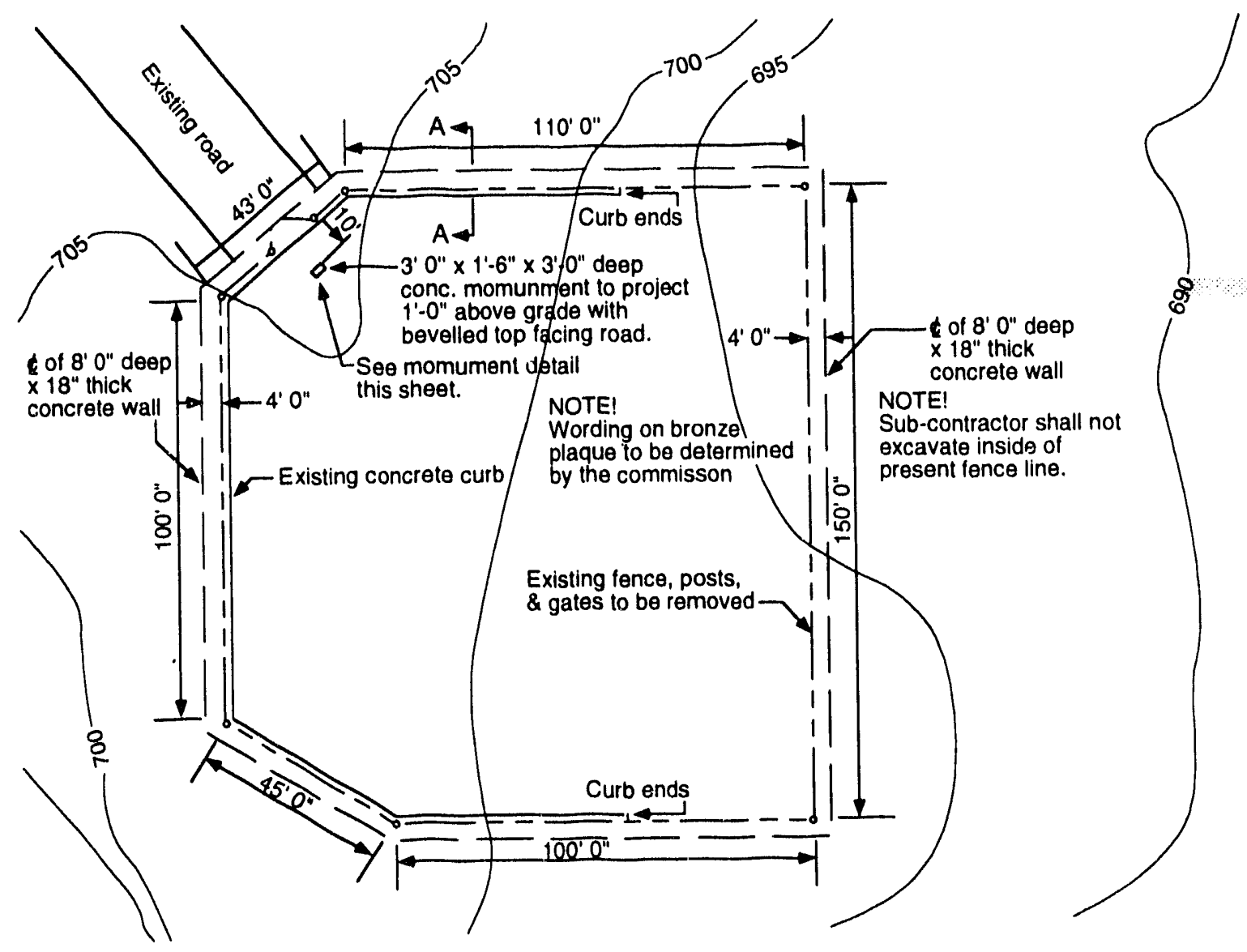

FIGURE 1.5 Architectural Design of the Concrete Cap for Plot M - Plan View (Source: Recreated from the original: ANL Plant Engineering drawing PE-A98, January 30, 1956) 


\section{SITE ENVIRONMENT}

\subsection{TOPOGRAPHY AND LAND USE}

Site $A$ and Plot $M$ are situated on a recessional moraine upland in southwestern Cook County (ANL 1979). The upland is characterized by a knobby topography with kettle holes. It is bounded by two transmorainic valleys, the Des Plaines River valley to the north and the Saganashkee Slough (or Sag Valley) to the south (Figure 2.1). Because the soil in the upland is rather inpermeable, swamps and lakes are common in the area. Streams are ephemeral, and either drain internally to local depressions or flow to one of the two transmorainic valleys.

Plot $\mathrm{M}$ was constructed on a flat surface. It is bordered by two ephemeral streams on its eastern and western sides. The streams are part of the Red Gate Woods Stream, which flows north to the Des Plaines River valley (Figure 2.2).

Site $A$ is located on a rolling upland and is surrounded by a few depressions (Figures 1.3 and 2.3). The northeast-oriented Horse Collar Slough is located northeast of the site. A drainage that originates in the drain field of Site A leads to the slough. Three other depressions are filled with water, forming small ponds southeast, north-northeast, and northwest of the site. The local relief near Site $A$ is about $20 \mathrm{ft}$.

Currently, Site $\mathrm{A}$ and Plot $\mathrm{M}$ are surrounded by the Palos Forest Preserve. The nearest developed recreational area is the Red Gate Woods picnic area, about 1,200 $\mathrm{ft}$ north of the northern boundary of Plot $M$. Site A and Plot $M$ are not in a developed section of the woods; thus, they are not readily accessible to the public by vehicular transportation. However, the area has many trails that are used for cross-country skiing, horseback riding, and hiking. These trails provide public access to Site A and Plot M.

\subsection{GEOLOGY AND HYDROGEOLOGY}

\subsubsection{Plot $M$}

\subsubsection{Geology}

The boring program conducted in 1976 (Olimpio 1984, Nicholas and Healy 1988) provided important information on the subsurface geology of Plot M. A detailed description of the surficial deposit was provided by Olimpio (1982). In summary, Plot $M$ is underlain by two tills: Malden Till and the overlying Wadsworth Till (both members of the Wedron Formation). Together, they are $140 \mathrm{ft}$ thick. The Wadsworth Till Member is a dense clayey silt, with numerous thin lenses and layers of sand and gravel in the upper 25 to $35 \mathrm{ft}$. These 


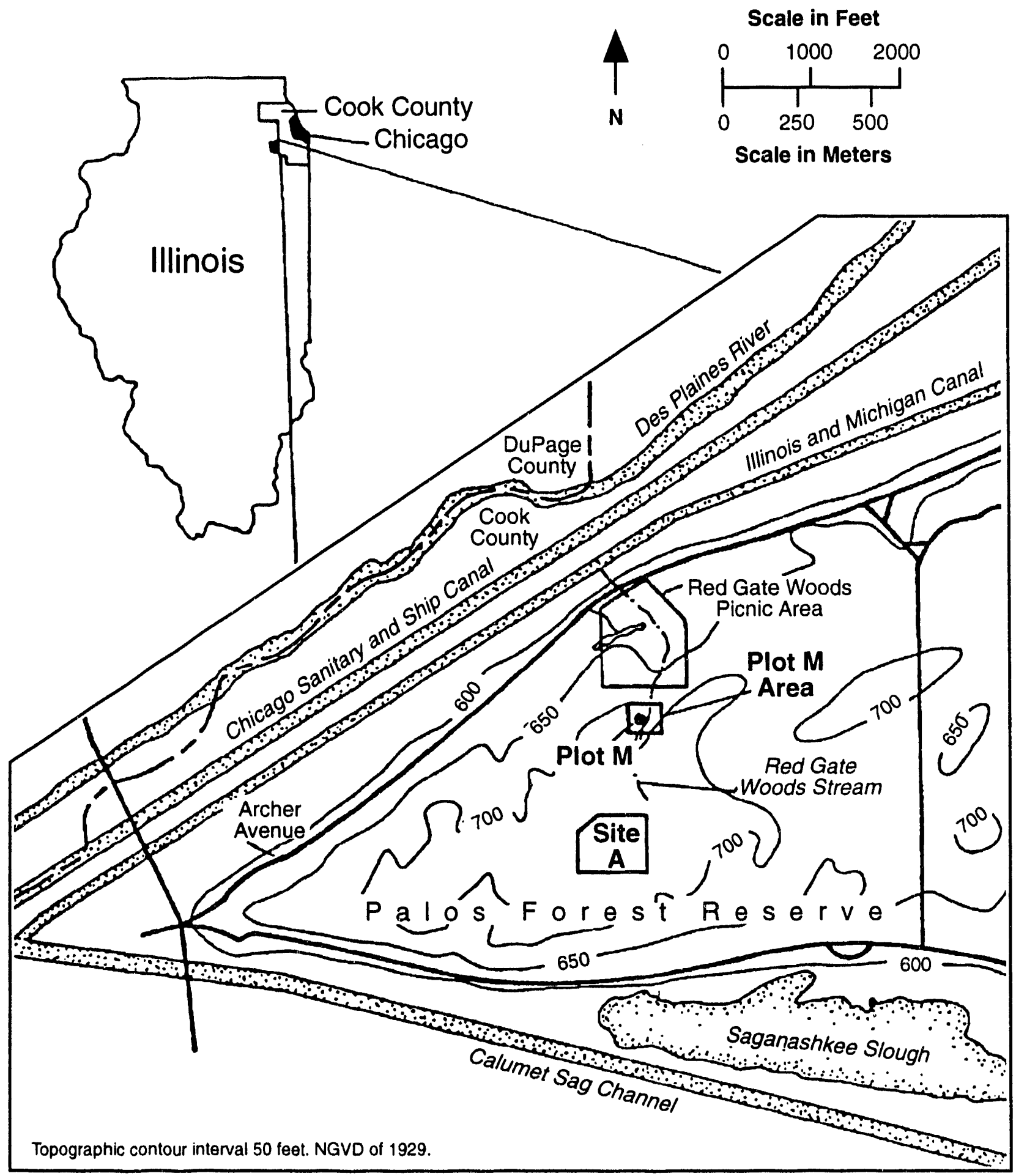

Based on U.S. Geological Survey Map:

Sag Bridge 1:24,000, 1963

FIGURE 2.1 Topographic Map of Site $A$ and Plot $M$ (Source: Nicholas and Healy 1988) 


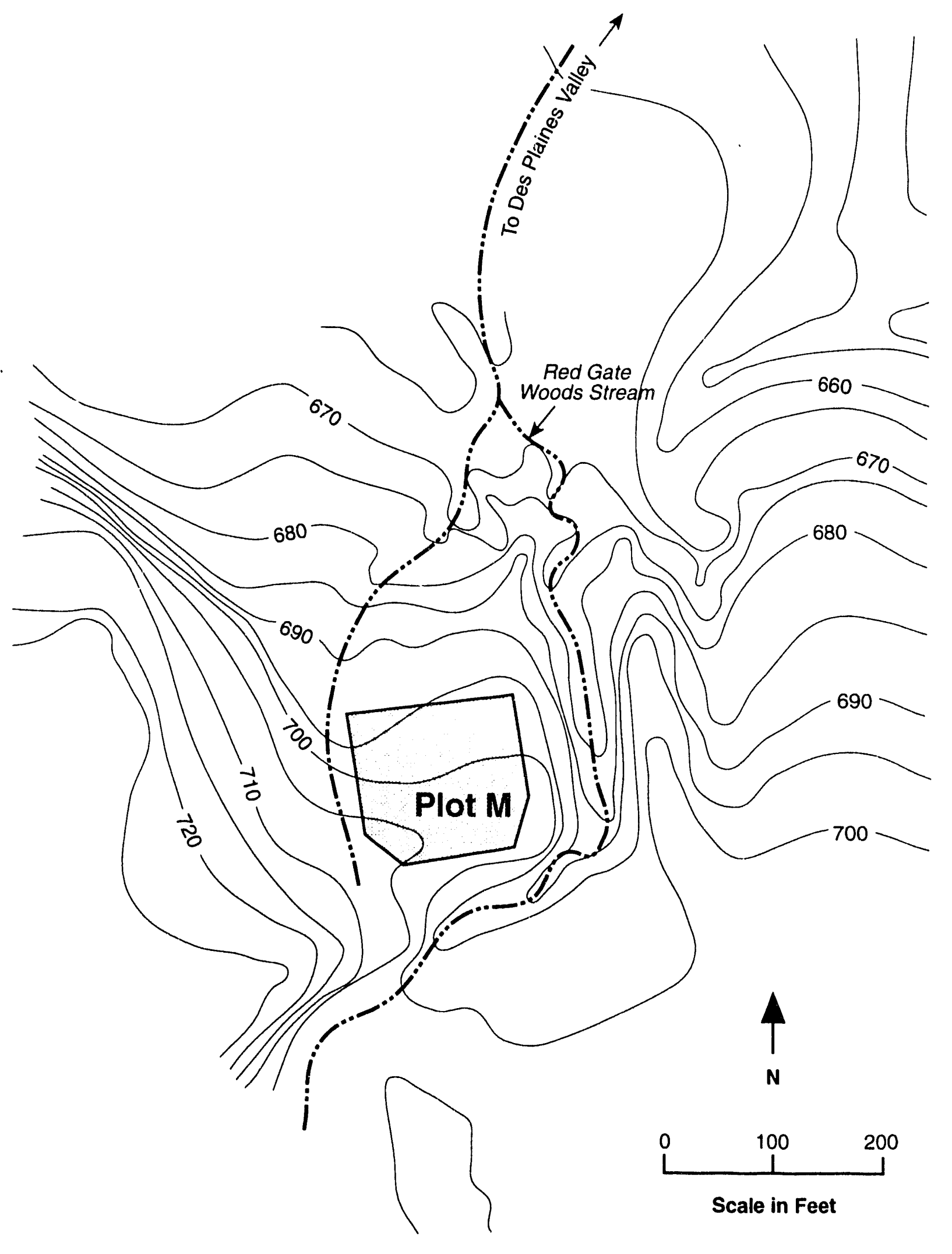

FIGURE 2.2 Topographic Map of Plot M (Source: Golchert 1991) 


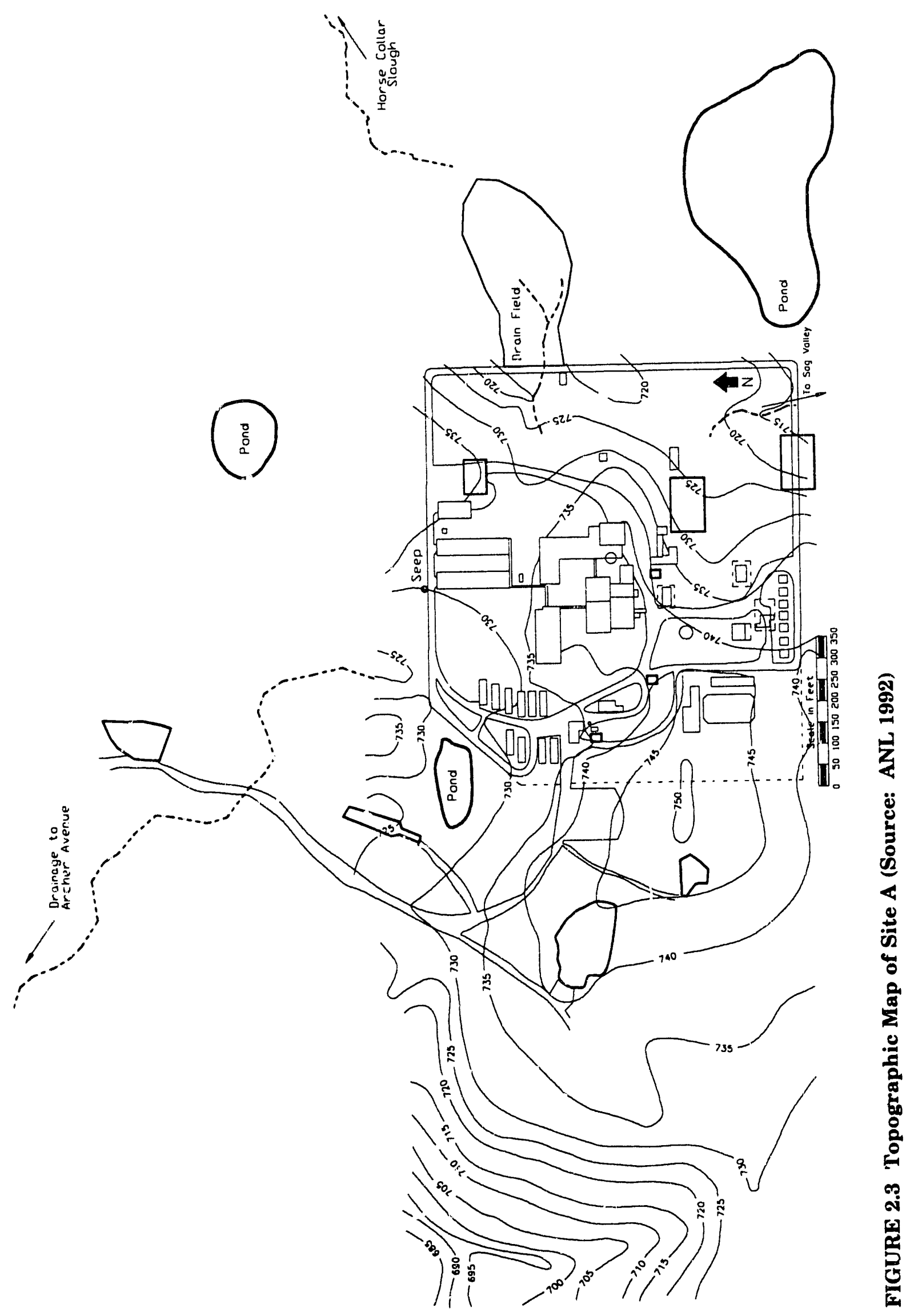


sand layers extend laterally for at least $300 \mathrm{ft}$ near Plot $\mathrm{M}$ and dip gently to the northwest. Sand-filled, subvertical fractures are present in the upper 10 to $15 \mathrm{ft}$ of the Wadsworth Till Member.

The Malden Till Member contrasts sharply in lithology with the overlying Wadsworth Till Member. The Malden Till contains mainly sandy silt and gravel. It is separated from the dolomite bedrock underneath by a thin layer of sand and gravel (Nicholas and Healy 1988). Figure 2.4 shows a north/south geologic cross section under Plot $M$.

The sand lenses and layers of sand and gravel in the Wadsworth Till can be related to its geologic setting. Plot M/Site $A$ is situated on one of the many Pleistocene recessional moraines in the region (Figure 2.5). Recessional moraines are commonly characterized by a series of shear planes along which glacio-basal materials are carried upward (Sugden and John 1976). In the case of Plot $M$ and Site $A$, the basal materials might be coarse-grained sand and gravel and weathered dolomite from the Malden Till and bedrock. The sand and gravel layers in the Wadsworth Till may have originated from the shear planes.

The uppermost bedrock below the glacial drift is a Silurian dolomite belonging to the Racine Formation of the Niagaran Series. The dolomite crops out along the northern bluffs of the Des Plaines River, about 3,000 ft northwest of Plot $M$. The dolomite has two dominant sets of vertical joints, oriented at $40^{\circ}$ and $130^{\circ}$ azimuth. Horizontal joints, as revealed in well logs, are well developed by dissolution along bedding planes (Nicholas and Healy 1988). The top of the dolomite is a weathered zone less than $5 \mathrm{ft}$ thick.

According to a seismic refraction survey in the Red Gate Woods picnic area (Figure 2.6), the surface of the subsurface bedrock in this region is characterized by karst topography, with numerous hills, valleys, and closed depressions (Nicholas and Healy 1988). The Red Gate Woods picnic area is about 1,200 ft north of Plot M. Although no seismic survey was made, similar bedrock topography is inferred in the Plot $M$ area.

\subsubsection{Hydrogeology}

Nicholas and Healy (1988) described the hydrogeology near Plot M in great detail. The glacial drift can be divided into an upper perched zone, a middle unsaturated zone, and a lower saturated zone (Figure 2.4). The perched zone is characterized by clayey silt enriched with gently dipped sand lenses and layers. Within this zone, groundwater levels fluctuate annually about $5 \mathrm{ft}$ in topographically low areas and about $25 \mathrm{ft}$ in topographically high areas. The highest water level occurs in April, and the lowest in the fall. Because of the heterogeneity of the aquifer, groundwater flows are influenced by a strong vertical hydraulic gradient, the presence of fissures in the Wadsworth Till, and the high permeability of the sand layers (Figure 2.4). Local topography can influence local groundwater flow direction toward drainages. A seep and an artesian condition in a well have been reported (ANL 1979, ORNL 1989) north of Plot $M$. The perched zone is about $25 \mathrm{ft}$ deep and is recharged from precipitation. 


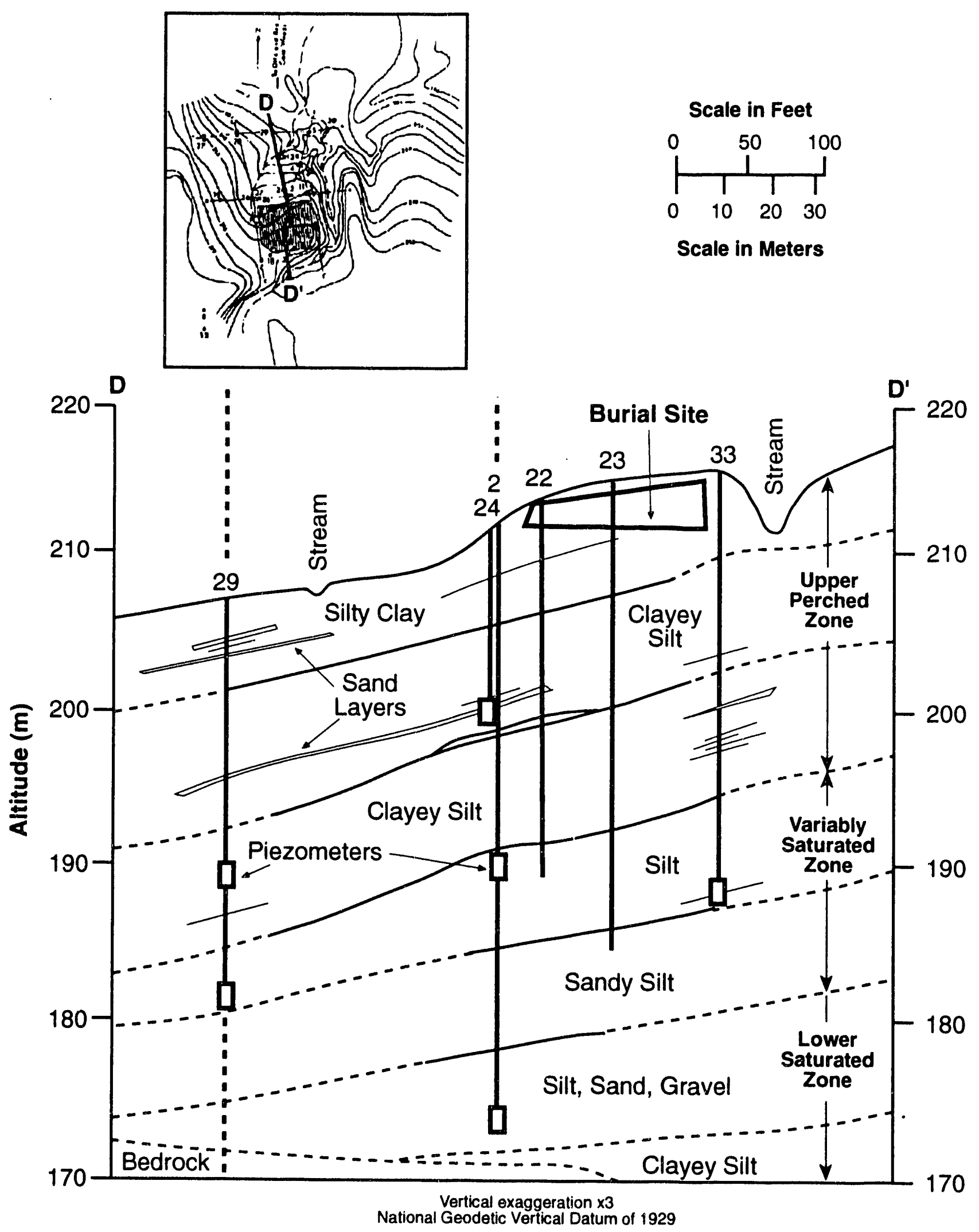

FIGURE 2.4 Geologic Cross Section near Plot M (Sources: Olimpio 1984, Nicholas and Healy 1988) 


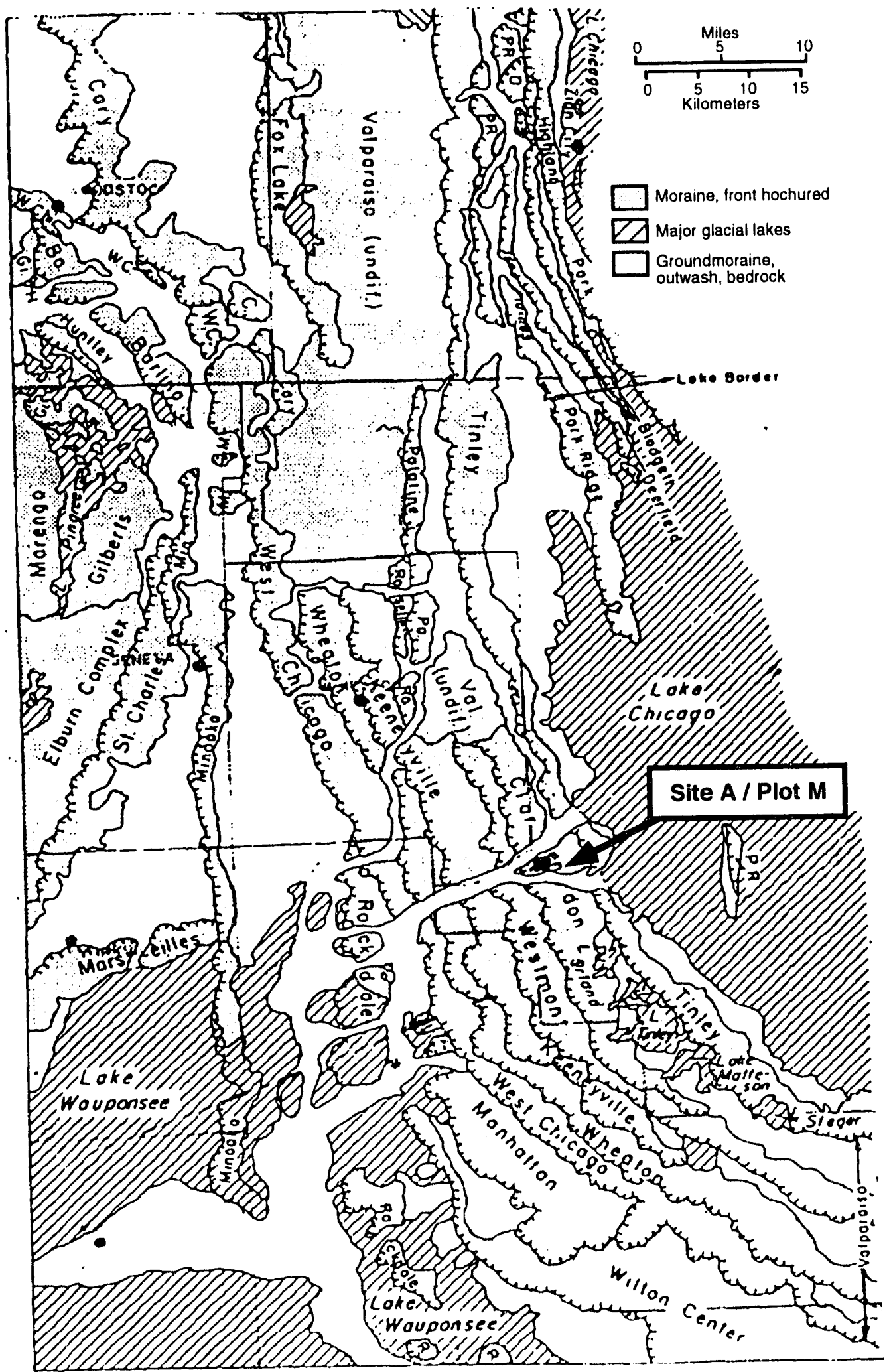

FIGURE 2.5 Recessional Moraines in the Chicago Area (Source: William 1973) 

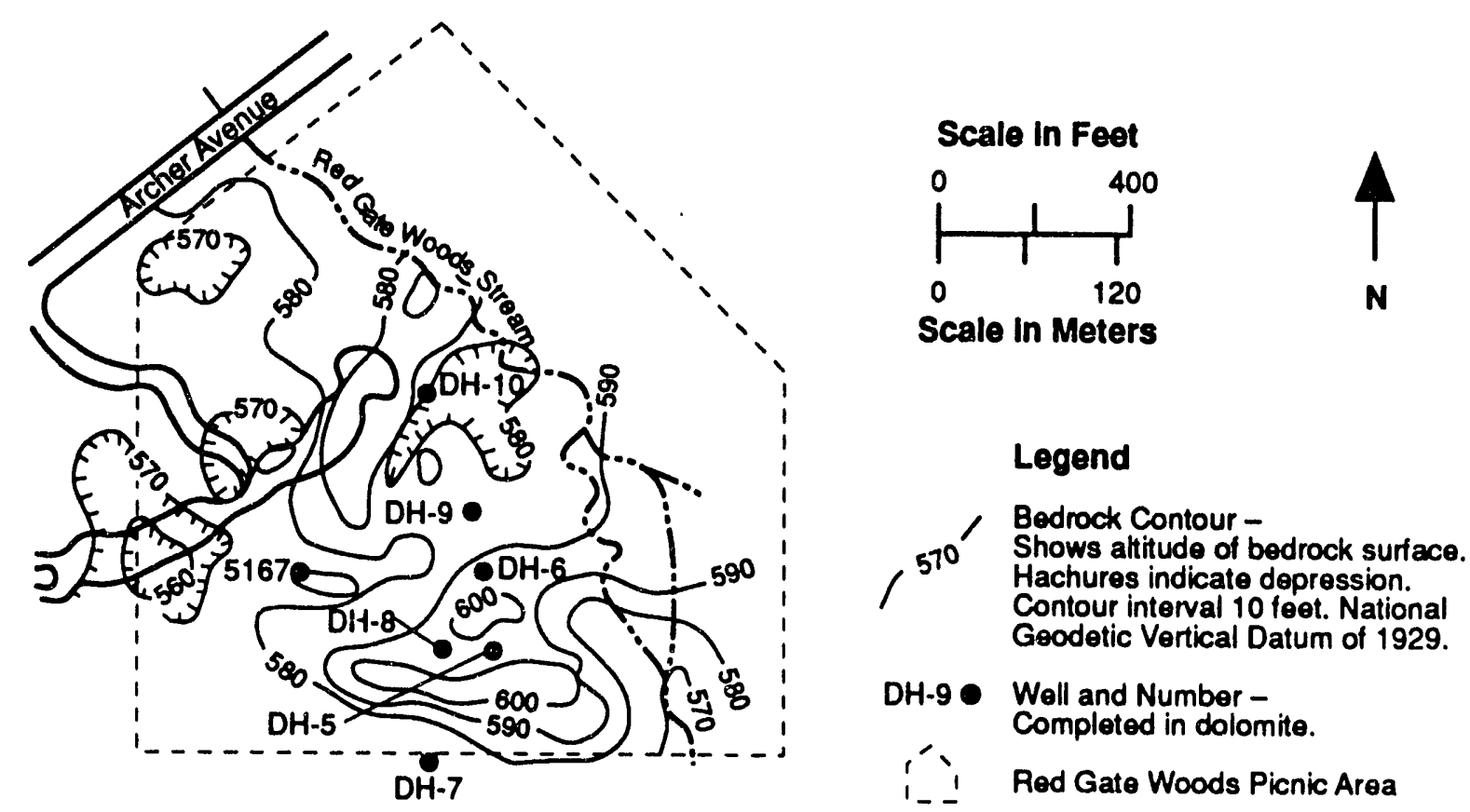

FIGURE 2.6 Topography of Bedrock Surface in Red Gate Woods Picnic Area (Source: Nicholas and Healy 1988)

The sand layers in the perched zone direct most of the infiltrated water along the layers. The clayey Wadsworth Till reduces vertical movement of infiltrated water. Under these conditions, an unsaturated zone is created under the perched aquifer. The unsaturated zone is about $35 \mathrm{ft}$ thick (Figure 2.4).

The sand and gravel near the dolomite bedrock form an unconfined aquifer, which has a downward hydraulic gradient. Groundwater tends to flow to the underlying bedrock aquifer, the dolomite (Nicholas and Healy 1988). The water levels measured in the sand and gravel aquifer are stable, fluctuating within a range of 1 to $2 \mathrm{ft}$.

The dolomite bedrock forms a major bedrock aquifer in this area. This aquifer is hydrologically connected to the overlying sand and gravel. Groundwater mainly flows along joints and in the bedrock weathered zone. The groundwater discharges toward the Des Plaines River to the northwest (Nicholas and Healy 1988).

\subsubsection{Site A}

\subsubsection{Geology}

The only site-specific information available on the geology underneath Site $A$ is contained in two well logs, DH-1 and W5195 (Illinois Geological Survey 1992). A 170-ft-thick glacial deposit overlies Site A. The deposit consists mainly of gray and clayey till, interspersed with dolomite rock fragments. According to well log W5195, two gravel layers, 5 and 
$3 \mathrm{ft}$ thick, were found at depths of 35 and $72 \mathrm{ft}$ below the ground surface, respectively. Adjacent to the bedrock, a layer of sand and a layer of gravel, totaling $40 \mathrm{ft}$, have been reported. However, the gravel layers reported in well log W5195 were not reported for well DH-1. Because only two well logs are available for the site, the extent of the sand and gravel layers within the till is not fully understood.

\subsubsection{Hydrogeology}

Very little hydrogeologic information is available for Site A. Therefore, the sitespecific hydrogeology must be inferred from nearby areas. Since Site A is near Plot M and has experienced a similar geologic history, they are likely to have similar hydrogeologic conditions, except that the groundwater in the dolomite aquifer at Site A may flow to the Saganashkee Slough to the south (refer to Section 2.2.1.2 for detailed information).

\subsection{SURFACE-WATER HYDROLOGY}

The Des Plaines River in the north and the Saganashkee Slough in the south both lie within a mile of Site A/Plot M (Figure 2.1). Within the two valleys, three canals have been constructed: the Illinois and Michigan Canal and the Chicago Sanitary and Ship Canal in the southern part of the Des Plaines River valley, and the Calumet Sag Channel in the Saganashkee Slough. Both valleys were drainage channels for ancient Lake Chicago (Figure 2.5). They are recharged by Lake Michigan and by the groundwater of the dolomite aquifer.

Two ephemeral streams flow along the eastern and western sides of Plot $M$ (Figure 2.2). The eastern one, the Red Gate Woods Stream, is narrow and deeply incised near Plot M. It is recharged by snowmelt, precipitation, and groundwater seepage in its upper reach (Olimpio 1984). In the last $2,000 \mathrm{ft}$ of its lower reaches, the stream has a cobbled and bouldered bottom. Stream water is lost through the streambed and seldom flows as far as Archer Avenue. However, during periods of high flow, stream water discharges into the Illinois and Michigan Canal. The ephemeral stream west of Plot $M$ is unnamed. It joins the Red Gate Woods Stream before the latter empties into the Des Plaines River valley.

In aerial photographs," three kettle ponds are clearly shown in the northwest, northeast, and southeast of the site (Figure 2.3). The pond in the northwest was reportedly used to supply Site A with water in case of a fire. All three ponds are fed by local runoff. The southeastern one is the largest, and it might also have received some discharge from the site. Three drainages originate from Site A (Figure 2.3). The eastern one receives discharge from the site and drains to the drain field. The southeastern one drains to the Sag Valley.

* In preparing this environmental review, we used old aerial photographs of the ANL-East site that were obtained from the ANL Film Library (maintained by the Media Services Department of the Information and Publishing Division). The following are the negative numbers for the photos used: OLDNEG \#1-850, 1-851, 1-852, 1-853, 1-854, 1-855, 147-24, and 9251. 
The third one drains the area northwest of Site A and empties into the Des Plaines River valley. A spring was recorded (Mills 1991) near the northern boundary.

\subsection{WATER USE}

The dolomite aquifer is the major groundwater source for drinking water in the forest preserve. The water supply wells in the preserve are shown in Figure 2.7. In the Red Gate Woods picnic area, the current water supply well (well 5160) is about 1,100 ft northwest of Plot M. It was installed in the summer of 1988 to replace a previous well (well 5167). Three other picnic wells (wells 5159, 5157, and 5158) were taken out of service in 1991 because high fecal coliform concentrations were found in the well water (Golchert 1992). Other water supply wells in the forest preserve include those on the east and south sides of the preserve (wells 5162, 5031, 5158, 5153, 5154, 5266, 5021, 5193, 5232, and 5148), which are not likely to be in the migration pathway of contaminants from Site A/Plot M.

\subsection{METEOROLOGY}

The area has a climate of cold winters and hot summers, typical of the upper Mississippi Valley but moderated by Lake Michigan (Golchert 1992). Annual precipitation averages about 33 in. The largest rainfalls occur between April and September. The average monthly temperature ranges from $21^{\circ} \mathrm{F}$ in January to $73^{\circ} \mathrm{F}$ in July.

\subsection{POPULATION}

Approximately 7.9 million people live within $50 \mathrm{mi}$ of Site A/Plot M. Within a 5-mi radius, the population is about 150,000 (Golchert 1992). A considerable portion of this population lies north and northwest of the site. 


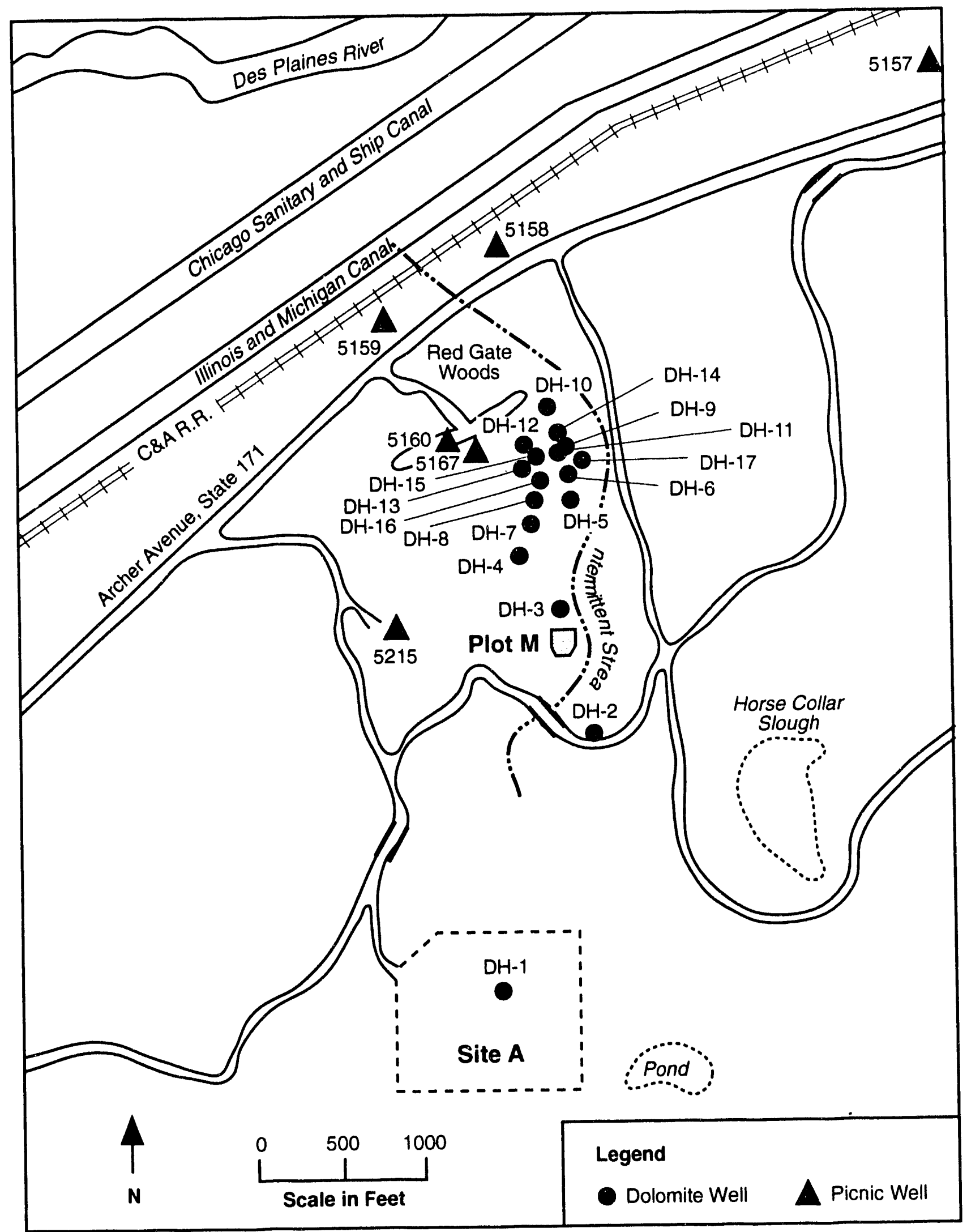

FIGURE 2.7 Water Supply Wells near Site $A$ and Plot $M$ in Palos Forest Preserve (Source: Golchert 1991) 


\section{CONCEPTUAL PATHWAY MODELS}

\subsection{MODEL DESCRIPTION}

A conceptual pathway model establishes a framework for identifying data needs and assists in the development of a general response to radioactive contamination. It also provides a consistent basis for assessing risks posed by a site. It identifies sources of contamination, release mechanisms, contaminant pathways, exposure routes, and receptors. As part of the source characterization, the potential contaminants of concern are identified.

The conceptual pathway models presented below for Site $\mathrm{A}$ and Plot $\mathrm{M}$ are intended to be general. They do not contain every possible release mechanism and migration pathway. Instead, they focus on those that are considered the most relevant, on the basis of our current understanding of the site. Also, the inclusion of a pathway in the models does not imply that it poses a threat to human health or the environment, nor does it indicate the magnitude of impact of that pathway. Rather, the models are intended to be used as tools to guide future investigations. After additional data have been collected, the models may need modification.

\subsection{PLOT M}

\subsubsection{Potential Contaminants of Concern}

The conceptual pathway model designed specifically for Plot $M$ is shown in Figure 3.1. The primary source of contaminants at Plot $M$ is the trenches that were filled with waste materials from May 1944 through 1948 . The secondary source is the soil around the trenches into which the contaminants have migrated. The extent of this secondary source is not clear at this time.

Because of their short half-lives, many of the radionuclides originally disposed of in the plot will have decayed to negligible levels by now. The contaminants remaining would be the long half-life (longer than 10 years) radionuclides and hazardous materials. The contaminants can be grouped into two categories. The first category is known contaminants, whose pr'sence can be confirmed with reasonable certainty by previous environmental sampling data or historical data. This category includes tritium, isotopes of uranium and plutonium, metals, chemicals such as acids and alkali, and organics.

The second category is possible contaminants, which are identified more by conjecture than by direct evidence. Given what is known about both the activities at the Metallurgical Laboratory sites around Chicago from 1944 to 1948 and the waste disposal practices at Plot $M$, we would expect to find contaminants such as thorium isotopes, radium-226, neptunium-237, beryllium-10, technetium-99, strontium-90, and cesium-137. 


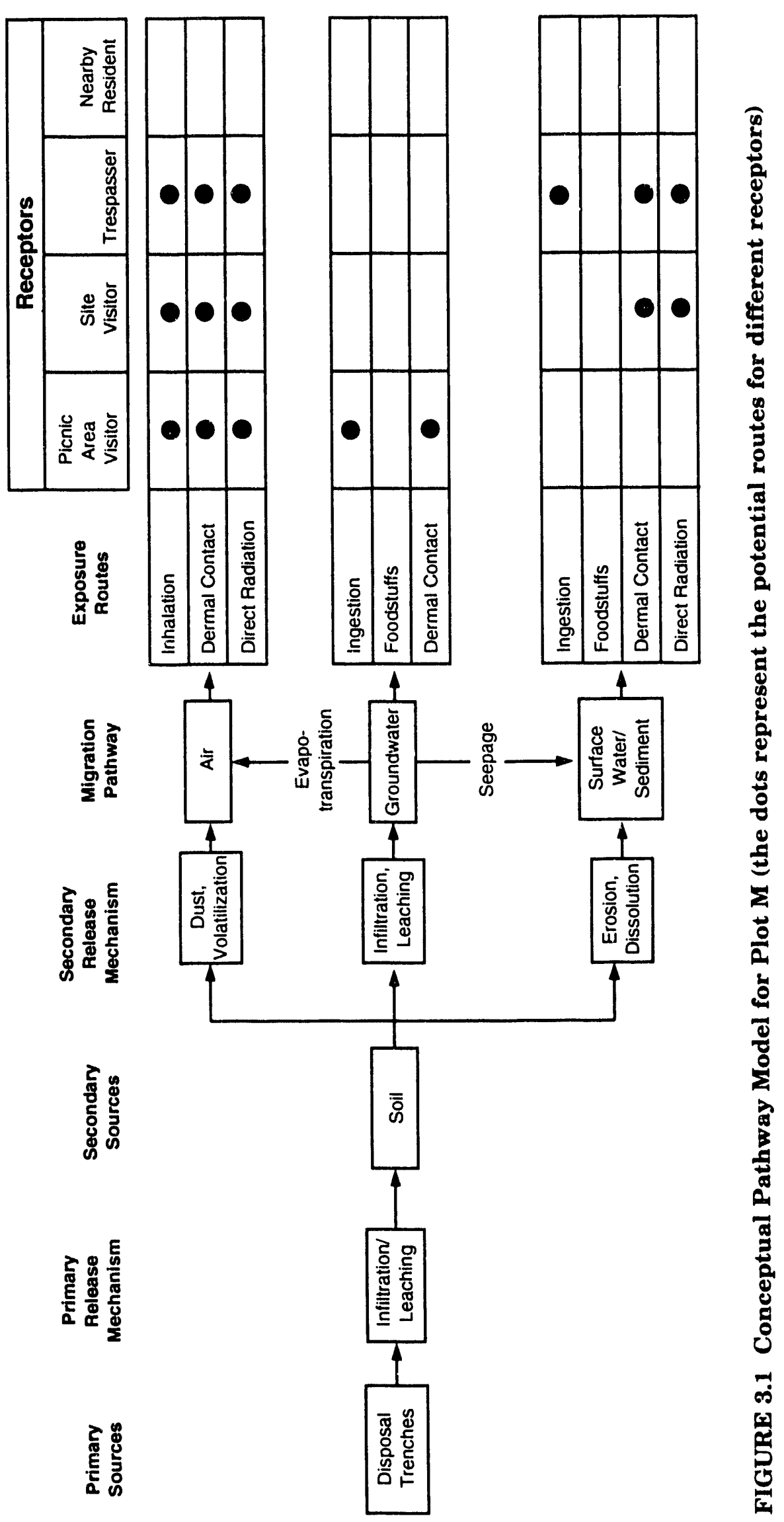




\subsubsection{Release Mechanisms}

The primary release mechanisms were the infiltration of liquid waste and the leaching of solid waste. The latter mechanism was prominent before the trenches were capped. When Plot $M$ was operating, standing water in trenches was observed on wet days, and it might have stayed there for a week or disappeared overnight (Young 1948). This standing water may have carried contaminants from the trenches into the soil under Plot $M$, where they have been found in soil cores and borehole water. In turn, such contaminated soil may become a secondary source of contaminants. It is likely that the disposal trench and its surrounding soil will continue to release contaminants. For example, near the seepages where contaminants are found, it is possible that contaminated soil and particulates will be dispersed by wind, evaporation of tritiated water, soil erosion, and dissolution by surface runoff. Under the plot, leaching and infiltration of contaminated soil could occur.

\subsubsection{Contaminant Pathways}

The main pathway for contaminant migration is through groundwater in both the saturated and unsaturated zones. Field data show that tritiated water has been detected in the air above Red Gate Woods Stream. The water might have been brought up by evapotranspiration from the perched aquifer. Also, seepage of the contaminated perched groundwater was recorded; this seepage brought contaminants up to the land surface and the surface waters near the plot.

\subsubsection{Exposure Routes and Receptors}

The potential receptors defined in the conceptual model include individuals who are likely to be exposed to contaminants released from Plot $M$. Only the baseline scenario is considered here. Other scenarios may be added in the future, if they are needed. The baseline scenario assumes no major disturbance of the site, including no excavation or drilling. The site conditions are assumed to be the same as current conditions. The potential receptors therefore include visitors to the Red Gate Woods picnic area, individuals who visit the plot as recreational users ("site visitors"), individuals who have access to the exterior of the plot and disturb (i.e., vandalize) the site or remove surface material to off-site locations ("trespassers"), and the local residents who live around the forest preserve ("nearby residents").

The exposure routes for the picnic visitors include the intake of groundwater obtained from the pumps installed in the picnic area and dermal contact with contaminants in the groundwater.

Site visitors and trespassers may inhale airborne tritium-contaminated water vapur or radon, come into dermal contact with the water vapor, and be exposed to direct radiation. Nearby residents are exposed by way of similar routes but to a much lesser extent, because the contaminants are dispersed in the air. Therefore, the exposure routes for residents are considered to be insignificant. 
Evaporation of tritium-contaminated water from the Red Gate Woods Stream creates other exposure routes for site visitors and trespassers, including dermal contact and direct radiation. In addition, trespassers are exposed to the ingestion route if contaminated surface water is consumed.

\subsection{SITE A}

\subsubsection{Potential Contaminants of Concern}

The potential sources of contaminants at Site A (Figures 3.2-3.5) include underground storage tanks (USTs); the buried reactor shield; the drain field northeast of the site; suspect areas 1 and 3-6; former building sites (such as the Old Lead Foundry, Storage Huts, and Quonset Huts), and the previous drain system. Suspect area 2 is not considered as a potential contaminated site because the surface radioactivity survey and surface soil sample results do not reveal any elevated radioactivity. The potential contaminants for each area are listed in Table 3.1.

\subsubsection{Underground Storage Tanks}

One UST was identified and removed by the Forest Preserve District of Cook County in 1988 (Golchert 1989). Since then, four additional suspected underground tank areas (tank suspect areas 1-4) have been identified (Figure 1.3). A tank has been confirmed at tank suspect area 1 by a ground penetrating radar (GPR) survey (ORAU 1991). It is located near the center of the site, but its exact location needs to be determined, because the GPR report (ORAU 1991) did not provide specific information. Tank suspect area 2 is in the northeastern part of the site, where GPR anomalies indicate two possible tank locations centered on grid points $315 \mathrm{~N}, 255 \mathrm{E}$ and $305 \mathrm{~N}, 265 \mathrm{E}$ (ORAU 1991). Tank suspect area 3 was identified because a riser pipe was reported. However, this tank area was not confirmed in the 1990 GPR (see Section 4). The location might have been incorrect, or it might have been closer to the Fire Station. The latter is suspected because a boiler was shown on the floor plan of the Fire Station. Tank suspect area 4 is located near the western boundary of the site. USTs are suspected here because a gasoline pump station is shown in old aerial photographs.

In addition to the above four tank areas, an old engineering drawing shows that a septic tank is present near the septic drain field in the eastern part of Site A (Figure 1.3). The status of the septic tank is not known.

No information exists on whether all suspected tanks are completely empty or partially full, nor are the characteristics of the constituents inside the tanks known. However, solvent vapors have been detected in soil gas collected in the northeastern tank area (see Section 4). It is reasonable to assume that at least some tanks may contain petroleum products. 


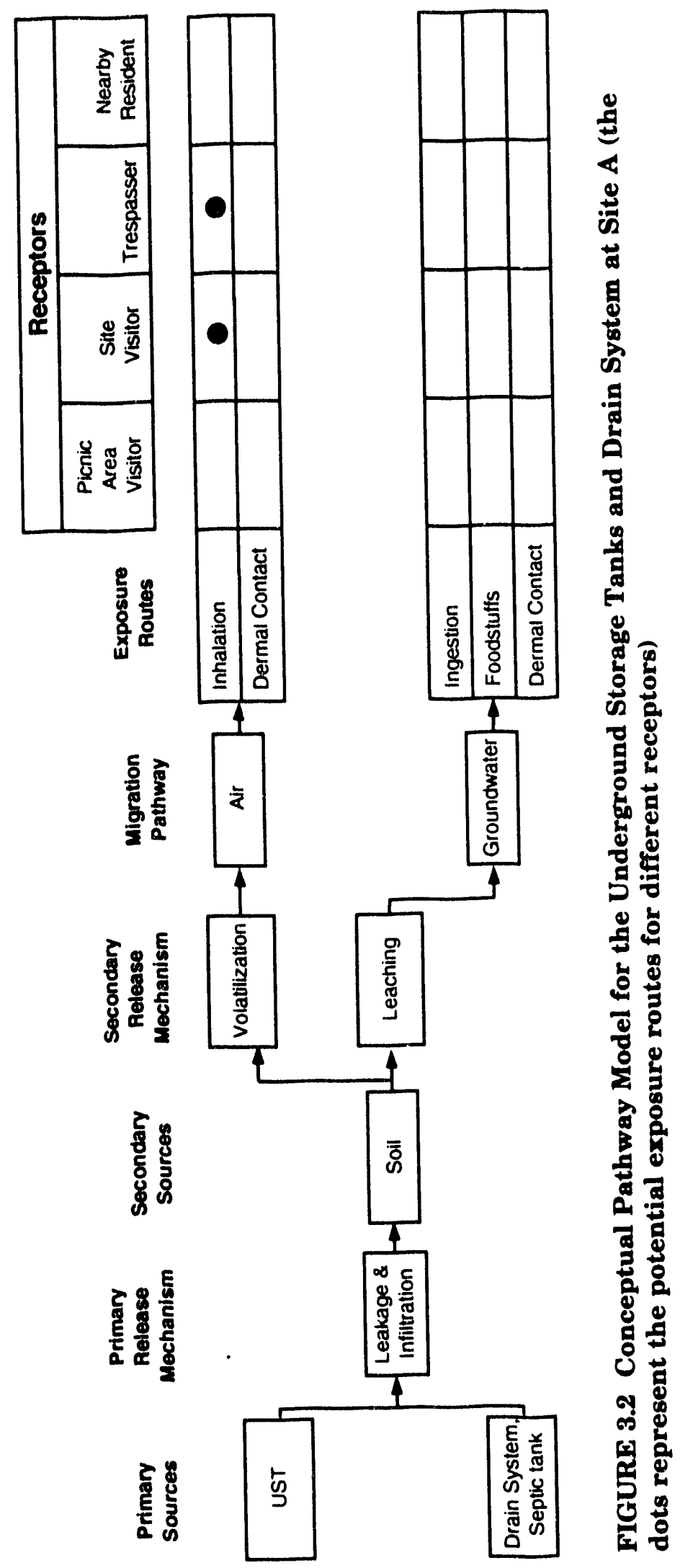



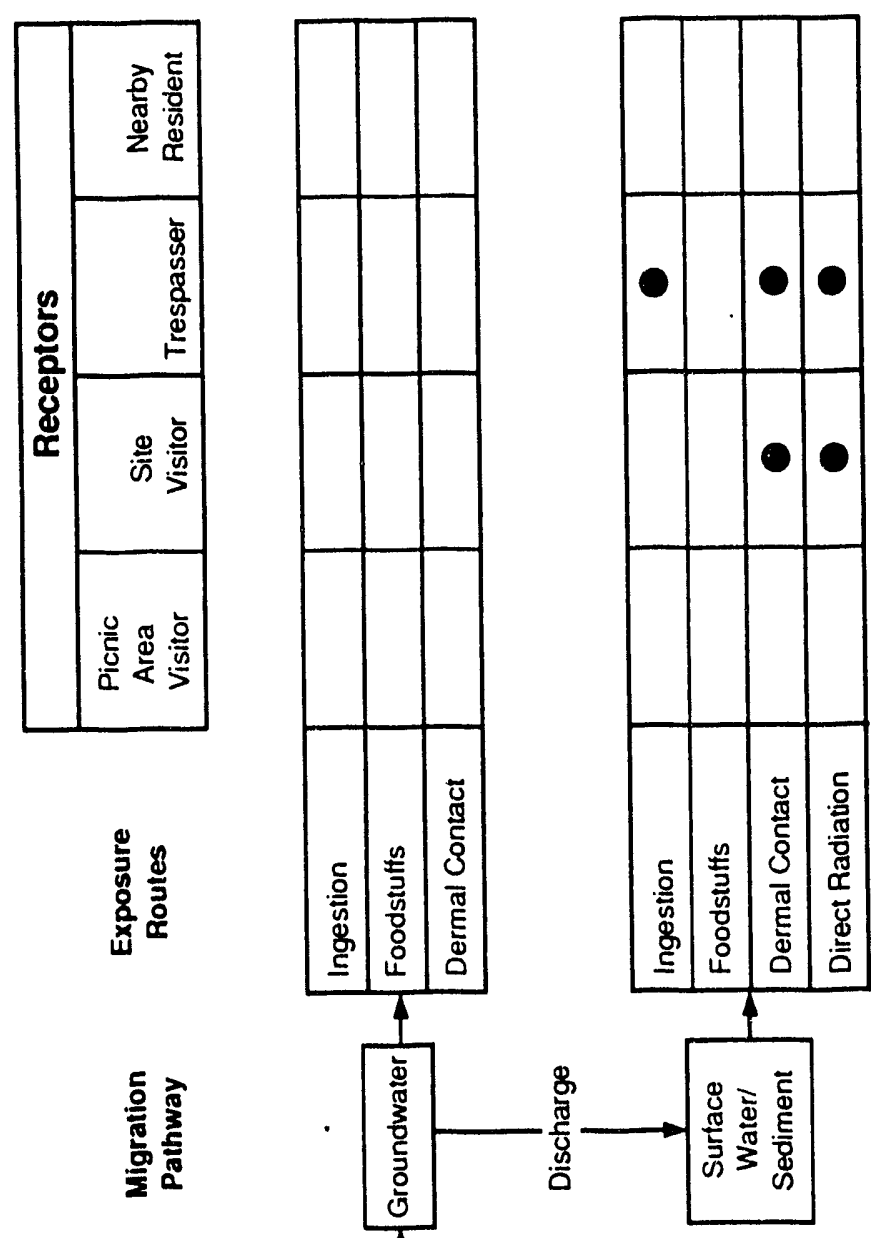

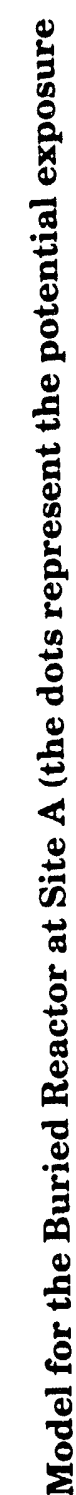

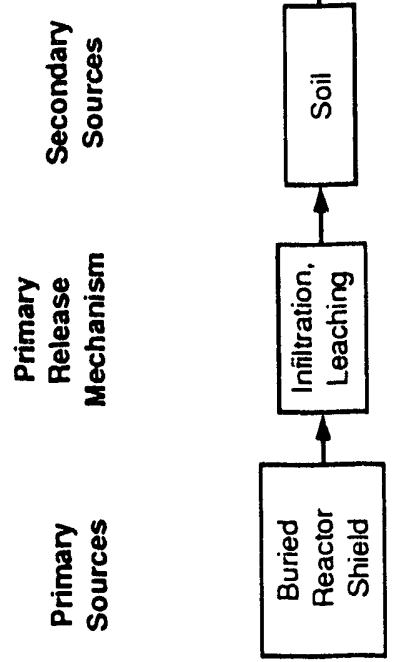

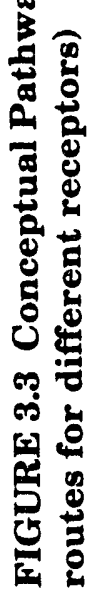




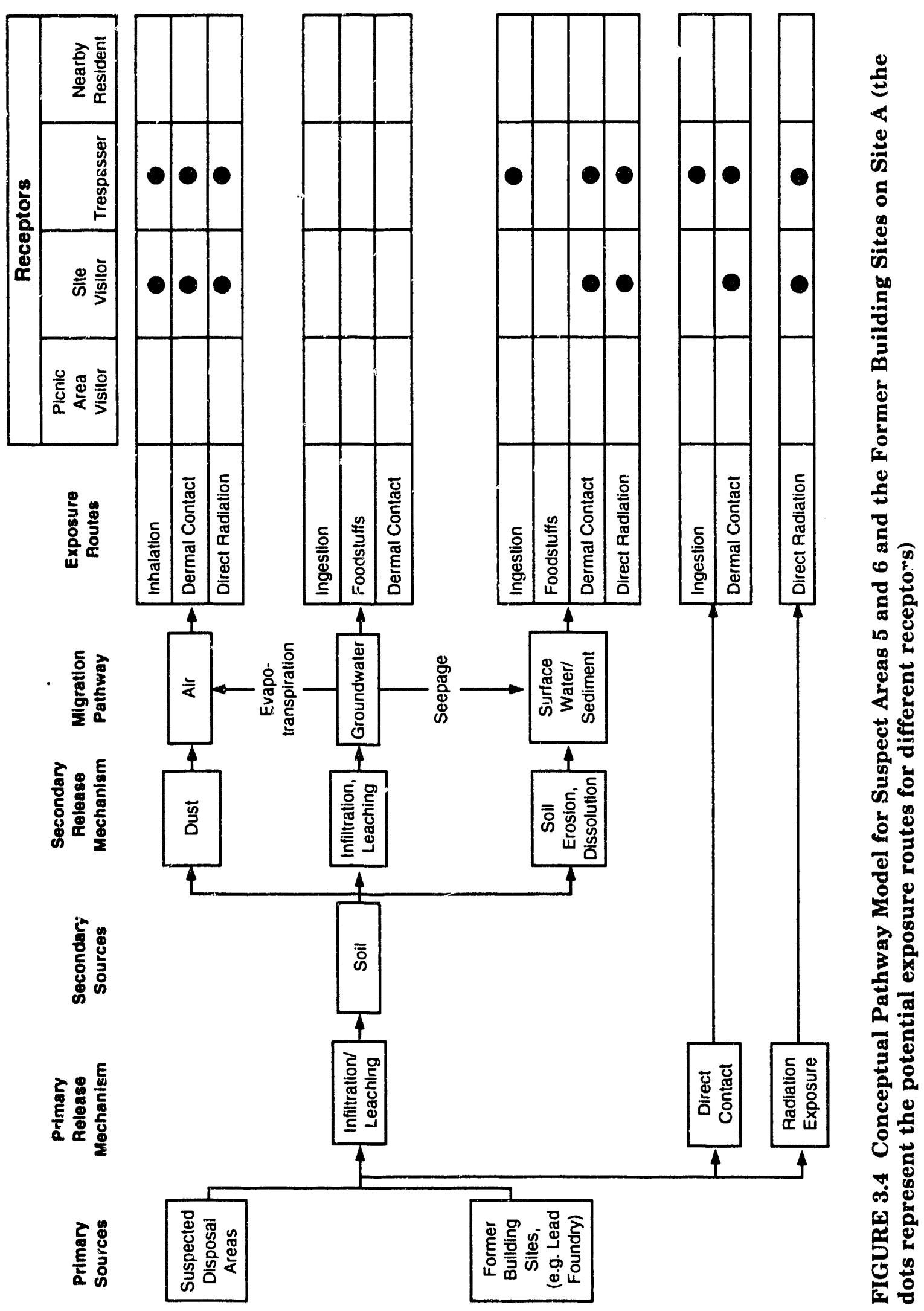




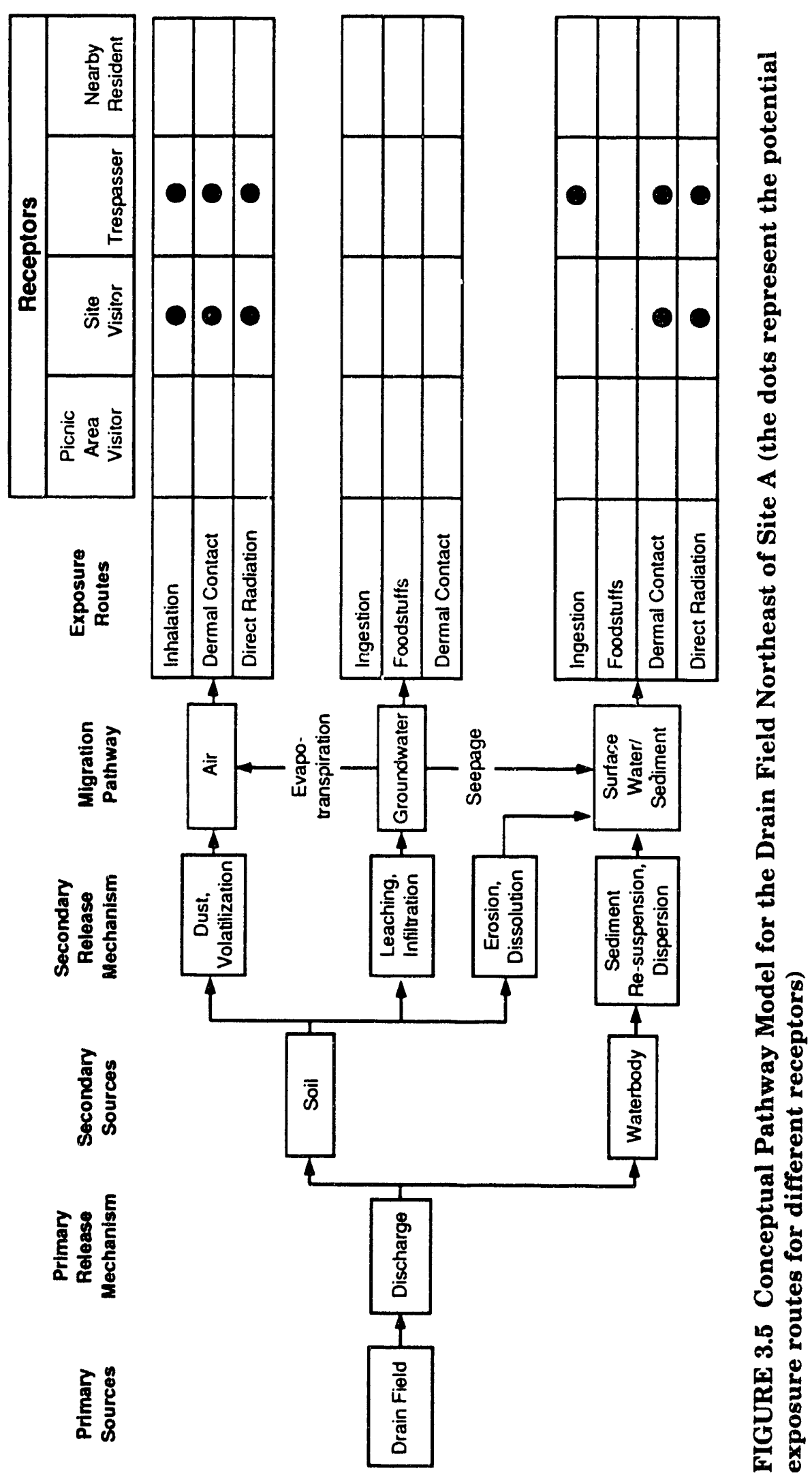


TABLE 3.1 Potential Contaminants at Site $A$ and Suspect Areas ${ }^{a}$

\begin{tabular}{ll}
\hline \multicolumn{1}{c}{ Area } & \multicolumn{1}{c}{ Potential Contaminants } \\
\hline Underground storage tanks $^{\text {b }}$ & Petroleum products, solvents \\
Buried reactor shield & $\begin{array}{l}\text { Lead, cadmium, H-3, C-14, Ca-41, Cl-36, Pb-205, and } \\
\text { Si-32 }\end{array}$ \\
Urain field & $\begin{array}{l}\text { U-238, -234, -235; Cs-137; Eu-152; acids; alkali; } \\
\text { organics; metals }\end{array}$ \\
$\begin{array}{l}\text { H-3 and others } \\
\text { Suspect area 1 }\end{array}$ & $\begin{array}{l}\text { U-238, -234, -235; Cs-137; Eu-152; asbestos; acids; } \\
\text { alkali; organics }\end{array}$ \\
$\begin{array}{l}\text { Suspect areas 3 and 4 } \\
\text { Uite A (includes suspect }\end{array}$ & $\begin{array}{l}\text { U-238, -234, -235; Cs-137; Sr-90; Pu-239, -240; lead; } \\
\text { acids; alkali; organics }\end{array}$ \\
building sites, drain system) & \\
\hline
\end{tabular}

a See Section 4.2 for additional information about potential contaminants.

b Tank suspect areas 1-4.

c No radioactivity above background levels has been detected on the surface. Tritiated water was found in a drainage near the Archer Avenue entrance. A branch of the drainage has a headwater near suspect area 1.

\subsubsection{Buried Reactor Shield}

Tritiated water has been found in soil bores taken around the burial site. Some of the buried reactor parts would be radioactive. Most of this radioactivity would be due to neutron activation of metallic components and concrete; therefore, it would be fixed in those materials. At the time it was buried, the concrete shield of CP-3 was intact. As a result, the shield would provide an extra barrier between the radionuclides inside it and the soil and/or groundwater around it. However, the concrete shield for CP-2 was demolished with a wrecking crane and pushed into the same excavation. Radioactive contamination may be present in the materials from the CP-2 shield.

\subsubsection{Drain Field}

The drain field (Figure 1.3) is where all laboratory wastewater was drained without any treatment. No information exists on the type and quantity of wastes being drained from the laboratories during their 11 years of operation. The gamma scans of 1990 (ORAU 1990) did not reveal any radioactive contamination on the surface of the drain field. However, a few surface soil samples contained low levels of uranium-238 (up to $6.6 \mathrm{pCi} / \mathrm{g}$ ). Therefore, 
both radioactive contaminants and nonradioactive contaminants (such as metals and organics) may be present underground.

\subsubsection{Suspect Areas 1 through 4}

Suspect areas 1 and 2 were preliminarily identified in a pre-Phase 1 study in the late 1980s. They are areas showing surface disturbance in aerial photographs from the 1940s and 1950s. In the 1990 Phase 1 radioactivity survey, neither area has radioactivity above background levels. However, the Illinois Department of Nuclear Safety (IDNS) found elevated tritium levels in a drainage near the Archer Avenue entrance. Because the drainage contains a branch that has a headwater near suspect area 1, this area warrants further investigation. Suspect area 2 , however, is eliminated as a potential investigation site.

The sources of contamination in suspect areas 3 and 4 (Figure 1.3) are thought to be intentional dumping of general laboratory waste and unintentional dumping of undetectable (with the instruments that were available at the time) quantities of radioactive materials. According to a memo (Young 1948), the disposal of radioactive wastes began in February 1944 at a location about $700 \mathrm{ft}$ west of Building $\mathrm{A}$. That location matches the locations of suspect areas 3 and 4. The memo states, "The first material disposed of was a group of ether solutions from the cyclotron chemical laboratory. These were burned with a few pieces of contaminated apparatus on the ground, later in an iron kettle . . " The later use of the suspect areas is not clear.

\subsubsection{Other Suspect Disposal Areas}

Two areas, one southeast of the Boiler House and the Well House (suspect area 5) and one near the southeastern corner of Site A (suspect area 6), are suspected as previous disposal sites (Figure 1.3; see Sections 4.3 and 5.2.2). These sites have been identified through the GPR survey, aerial photographs, and old documents. The sites probably were used in 1943 before Plot $M$ was built. The nature of the potential contaminants is not fully

understood. However, elevated radioactivity has been reported near the surface on the site nearest the Boiler House.

\subsubsection{Former Building Sites}

Residual contamination may be present in some former building sites, such as the former Lead Foundry and Storage Huts. Also, some wastes were discharged to the drains of buildings (Young 1948) and then to the environment. Either radioactive or nonradioactive contaminants, or both, could be found at these sites. 


\subsubsection{Release Mechanisms}

Release mechanisms are related to where the contaminant source is located. For example, the suspect landfills, the former building sites, and the drain field have near-surface sources. Leaching and infiltration are important release mechanisms for these sources. If the contaminants are in liquid form, they can also contaminate nearby water bodies. Particulate contaminants can be dispersed by wind, transported by surface runoff, or dissolved by water.

For subsurface sources, such as the USTs and the buried reactor shield, the primary release mechanisms are potential leaks in the tanks, infiltration, and leaching.

\subsubsection{Contaminant Pathways}

Surface runoff may provide a pathway for sources near the surface. However, this pathway is not considered a major one because the clay minerals in the till can bind cation contaminants. The contaminated soils are subject to erosion because they are underlain by relatively impermeable till. The sediments and surface water around Site A do not show elevated levels of radionuclides (see Section 4.2.4).

Groundwater movement provides another potential pathway for contaminants, which appears to be an active pathway at Site A because water samples taken from well DH-1 (a dolomite aquifer well) show low levels of acetone (700 ppb; see Section 4.2.3) and methyl ethyl ketone $(140 \mathrm{ppb})$. The latter probably was an impurity in the acetone. The source of the acetone is not known. Because acetone does not occur naturally, a groundwater pathway must be present to transport the contaminant to the groundwater.

\subsubsection{Exposure Routes and Receptors}

The exposure routes and receptors in the models for Site A differ in two major ways from those of Plot M. First, no evidence indicates that contaminants from the site have traveled to the picnic area. Therefore, the picnic area visitors are not considered potential receptors. Second, radioactive contaminants have been recorded near the ground surface at the site. Direct contact with these contaminants and exposure to the radiation from them would provide additional exposure routes that are not present in the Plot M models. 


\section{PREVIOUS SAMPLING EVENTS}

Since 1956, when Site A was decommissioned, several major environmental studies have been performed at Site A and Plot M, in addition to annual site surveillance. This section reviews the studies and summarizes their results. Table 4.1 lists the studies done since 1956.

\subsection{PLOT M AND RED GATE WOODS PICNIC AREA}

In November 1973, tritium was detected in a hand-pumped water well located in the Red Gate Woods picnic area. It was assumed then that the source of the tritium was Plot M. Periodic sampling of the forest preserve wells began shortly after this discovery. The primary focus of the sampling program was the analysis of radionuclides, especially tritium. From 1976 to 1978 , a radiological characterization of Plot M took place. That study determined that very low levels of tritium (hydrogen-3), as tritiated water, had migrated from the burial ground and were present in two nearby hand-pumped picnic wells downgradient from Plot M. Since then, a Surveillance and Maintenance Program has been ongoing. This program consists of sample collection and analysis of air, surface waters and groundwaters, and sediment. Until 1991, only radionuclides were analyzed. During the last quarter of 1991, groundwater from wells DH-1 through DH-4 was analyzed for Target Compound List (TCL) constituents. Because of the volume of data collected during this program, the detailed results will not be discussed in this document. Rather, a summary of pertinent events will be provided.

\subsubsection{Soil}

Between the springs of 1976 and 1977, a total of 18 borings were drilled (Table 4.2 and Figure 4.1), including 8 borings around Plot M. Two of these borings (9 and 10) were made at an angle of $45^{\circ}$ to a depth of about $40 \mathrm{ft}$ below Plot $\mathrm{M}$, and two others were drilled through the concrete cap of the plot (Golchert and Sedlet 1977). Samples from these borings were analyzed for tritium, uranium, cesium-137, strontium-90, and plutonium.

Samples collected showed that elevated concentrations of tritiated water exist throughout the Plot $\mathrm{M}$ area. By using tritium as a guide, the extent of contamination caused by Plot $\mathrm{M}$ can be summarized as follows (see also Table 4.2). Tritium concentrations as high as $107,000 \mathrm{nCi} / \mathrm{L}$ have been detected under Plot $\mathrm{M}$. Most of the plume (defined as a tritium concentration in soil moisture higher than $1,000 \mathrm{nCi} / \mathrm{L}$ ) is located from $14 \mathrm{ft}$ to $81 \mathrm{ft}$ under the plot. The thickness of the plume varies with location. In general, the tritium levels were about an order of magnitude higher in the area directly beneath the plot than in the area around the plot. The plume has two preferred movement directions, downward and northward. Tritium contamination now extends more than $200 \mathrm{ft}$ north of the northern boundary of the plot. However, tritium contamination has not been detected in the area 


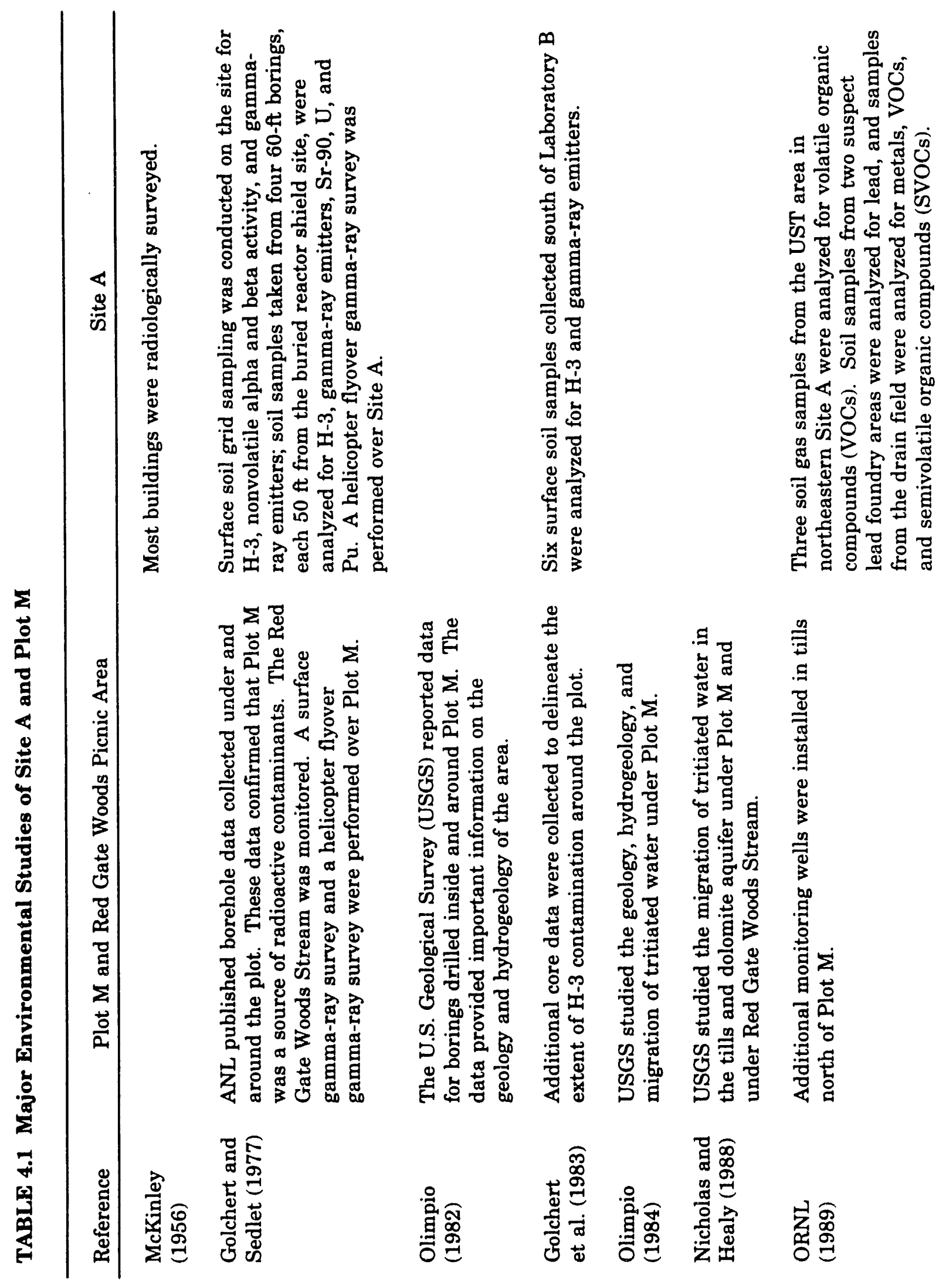




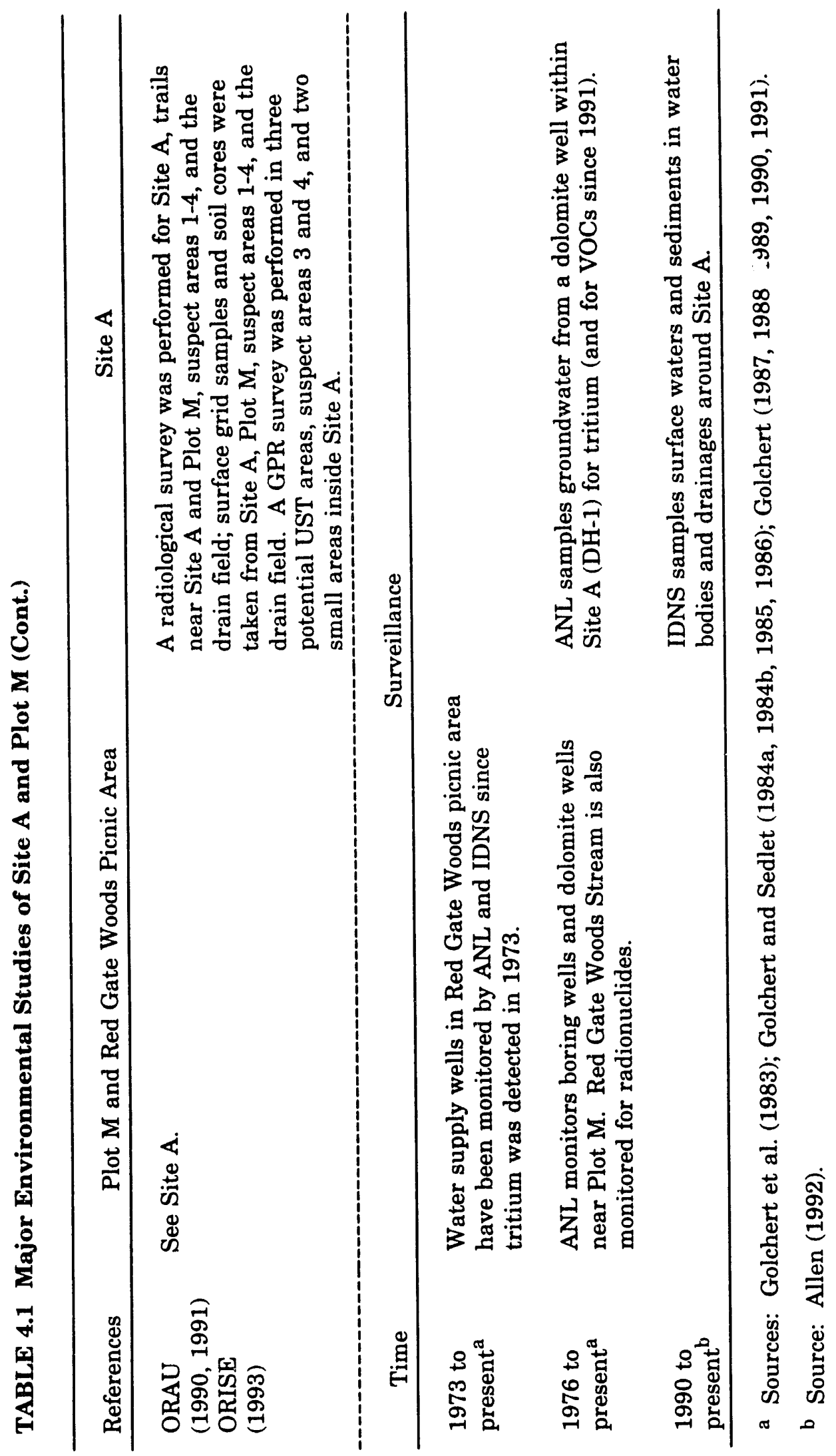




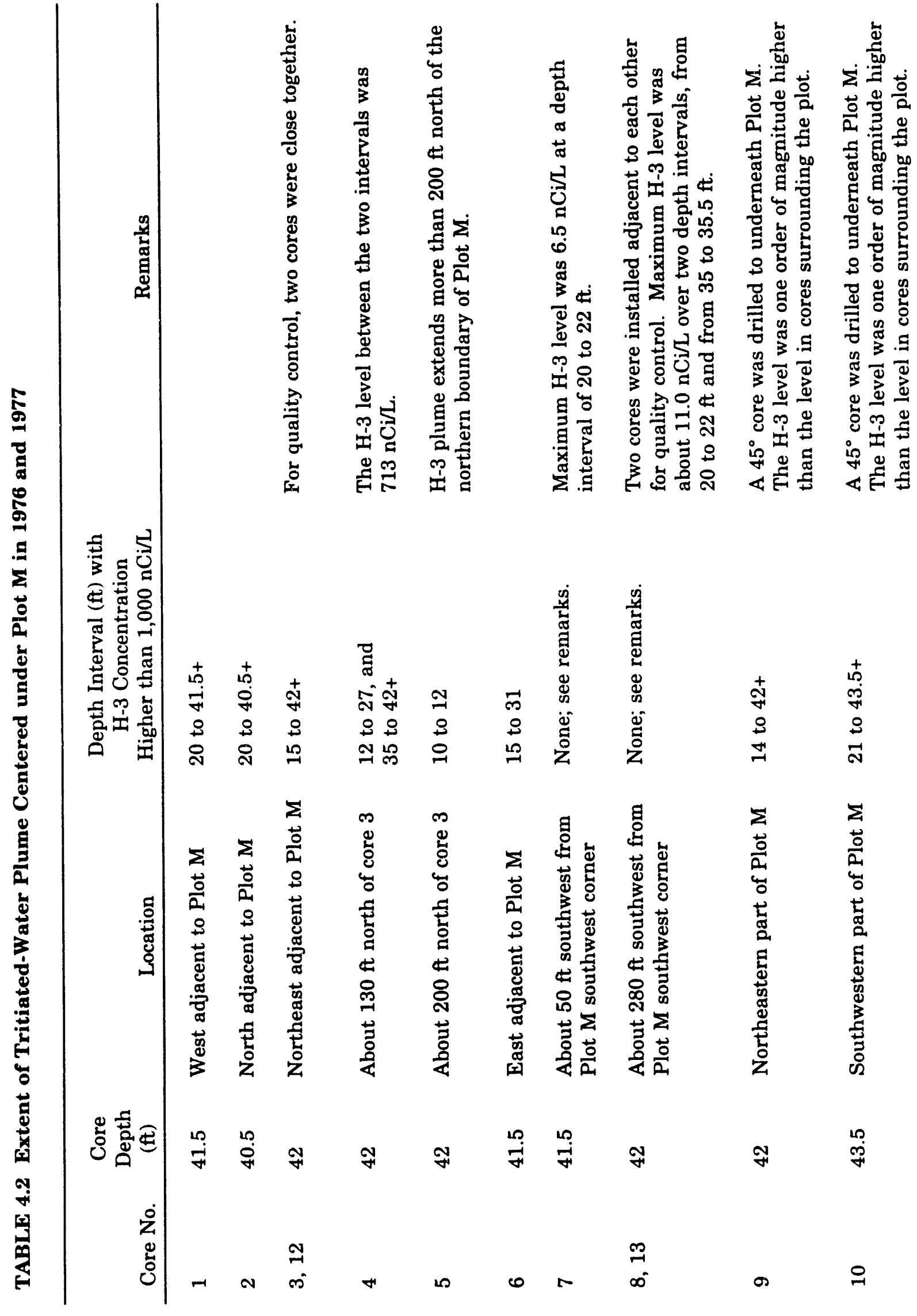




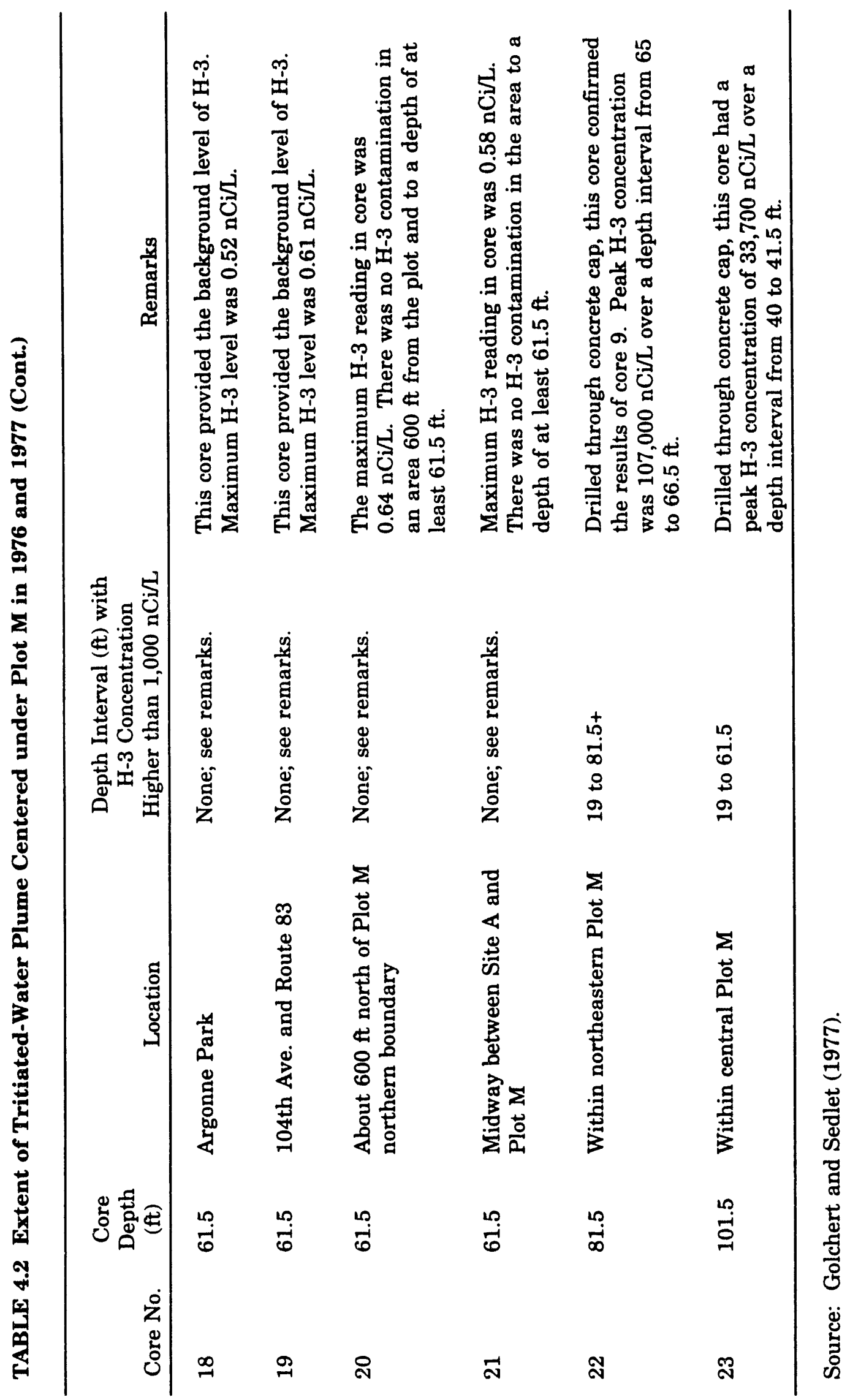




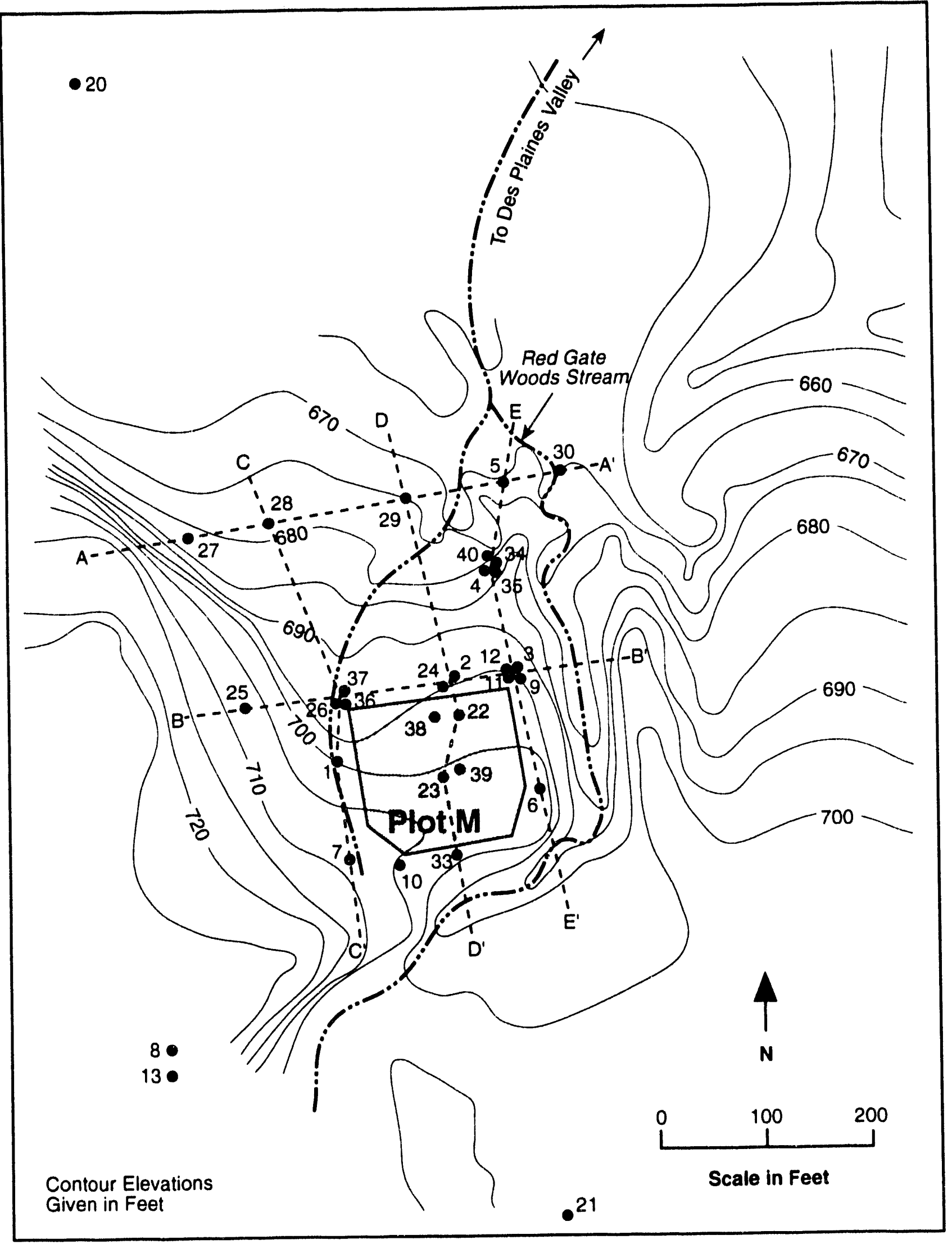

FIGURE 4.1 Boring Locations at Plot $M$ (Source: Golchert 1992) 
midway between the Red Gate Woods picnic area and Plot M or in the area midway between Site $A$ and Plot $M$. The background tritium level in soil moisture was below $1 \mathrm{nCi} / \mathrm{L}$ near Site $A$ and Plot $M$.

Between 1977 and 1982, 17 additional holes (11, 24 to 39; Figure 4.1) were bored. Soil samples were collected from each boring (except 34 and 37 ) to further characterize the extent of the tritium plume under Plot M (Table 4.3; Golchert et al. 1983, Golchert and Sedlet 1984b). Two of the borings (38 and 39) were drilled through the concrete cap. Samples were taken continuously to within 5 to $10 \mathrm{ft}$ of the bedrock surface. The borings were approximately $130 \mathrm{ft}$ deep.

The results from these borings confirmed that the tritiated water underneath Plot $\mathrm{M}$ has migrated close to the bedrock (Figures 4.2 and 4.3). For example, the tritium concentration in core water near the bottom of core 24 (126 ft deep) was $2,880 \mathrm{nCi} / \mathrm{L}$. The depth of the plume center varies from place to place, ranging from about $40 \mathrm{ft}$ in the southern part of Plot $\mathrm{M}$ to about $60 \mathrm{ft}$ in the northern part of Plot $\mathrm{M}$. The principal migration direction was downward. Smaller plumes, which indicate a secondary migration direction, were found trending north. The northern extensions correspond with sand and gravel layers in the tills (Golchert et al. 1983). Contamination was found in the upper part of the tills more than $200 \mathrm{ft}$ north of the northern edge of Plot M (Figure 4.3).

Soils from the Plot M area are not sampled as part of the quarterly surveillance and maintenance program. Since 1982, no core samples have been collected. The decay of the tritium and the movement of the plume since 1982 are not fully understood.

\subsubsection{Groundwater}

\subsubsection{Glacial Tills}

Because the borings had already been drilled, some of them were converted to monitoring wells (borings 1-11 [except 7], 24, 26, 28, 35, and 36). All wells were screened in the bottom $5 \mathrm{ft}$ of the borings. For borehole 11, two additional wells were installed. They were screened at two depths, $39 \mathrm{ft}(11-\mathrm{a})$ and $68 \mathrm{ft}(11-\mathrm{b})$ below the land surface. Groundwater levels and the water quality of the wells have been monitored regularly since 1982 . The results are described below.

Data from the shallow wells (Figure 4.1) adjacent to Plot $M$ (wells 6, 9, 10, 11-a, and 26) show that tritium levels fluctuate significantly with the seasons, from low in the spring to high in the fall and winter. The highest readings were found in wells screened in soil underneath the plot, such as wells 9 and 10. In some wells, tritium levels under the plot declined between 1982 and 1985 (Figure 4.4). Recently, the highest tritium level was $17,700 \mathrm{nCi} / \mathrm{L}$, measured in well 9 in July 1991 (Golchert 1992). The decline in the tritium level is less pronounced for well 6, near the eastern edge of Plot M (Figure 4.5). 


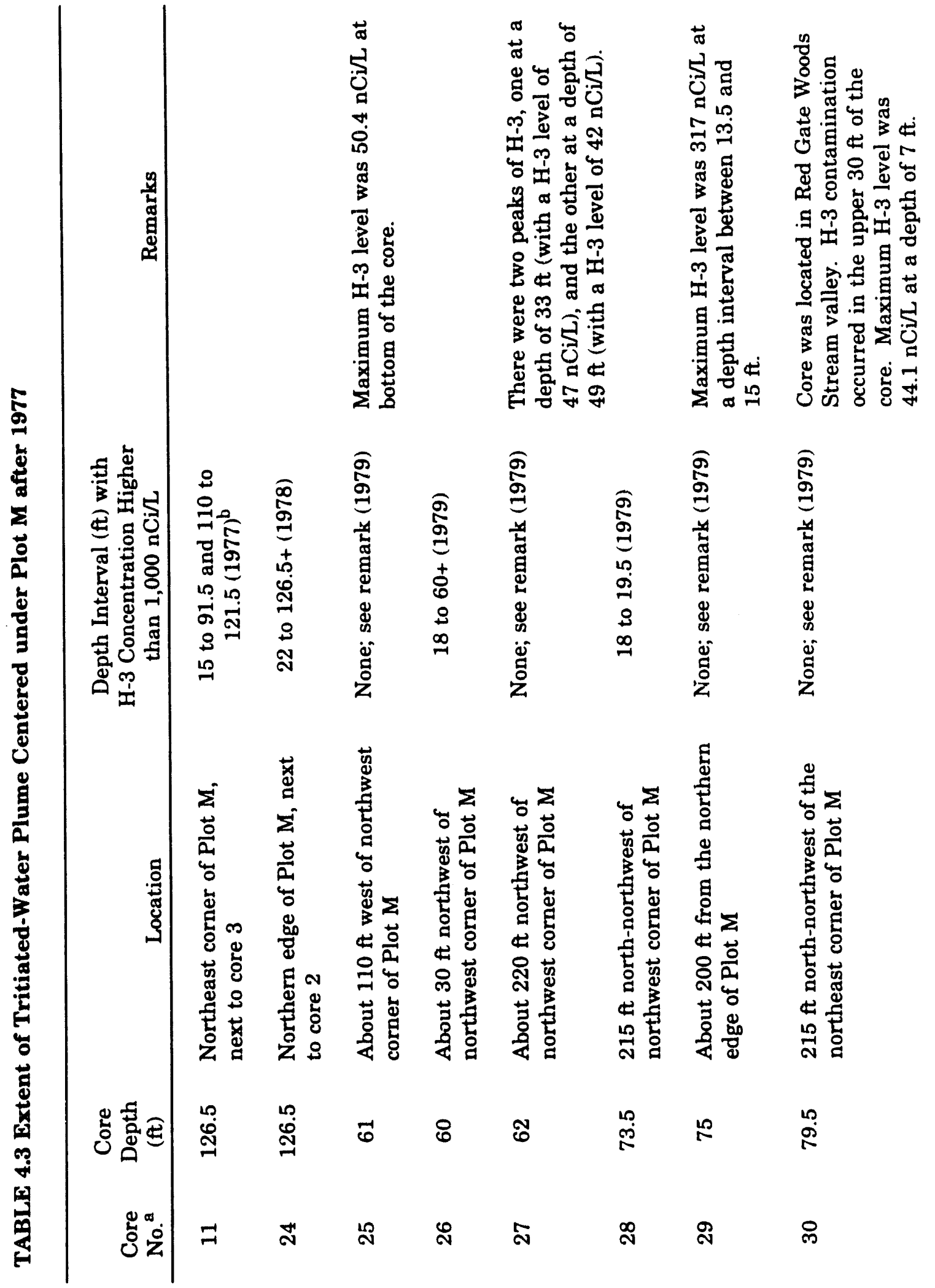




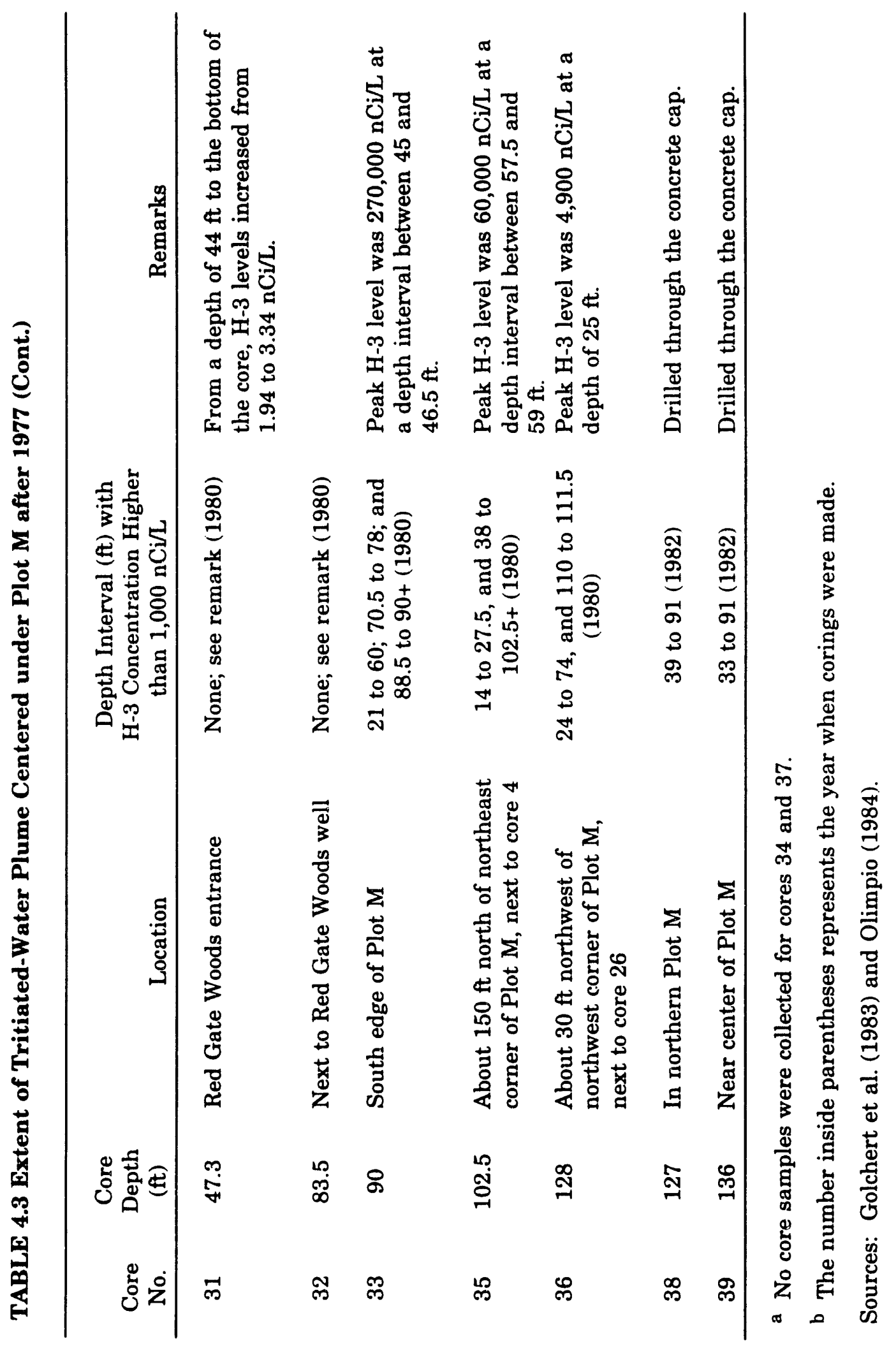




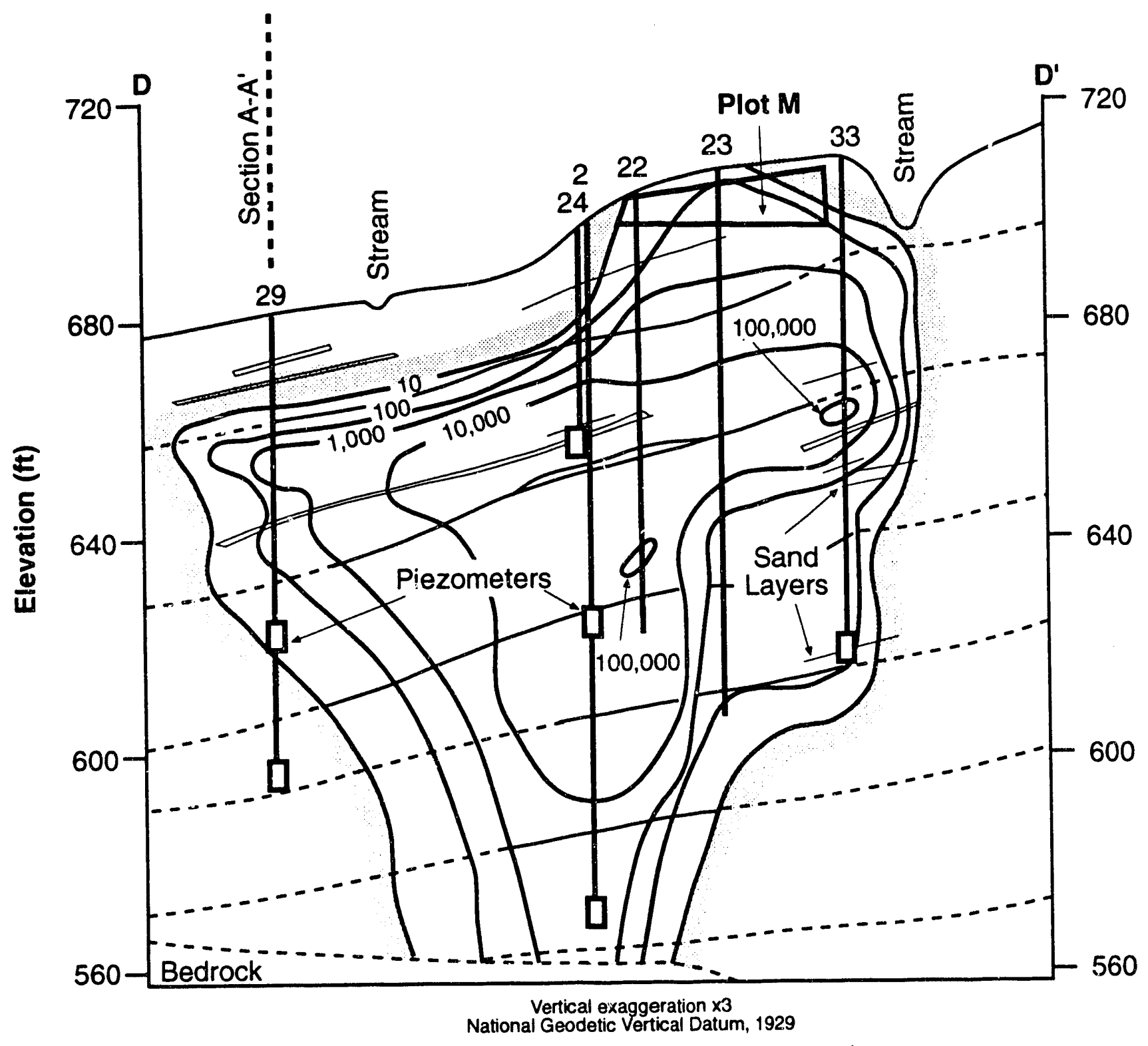

Scale in Feet

Line of equal tritium
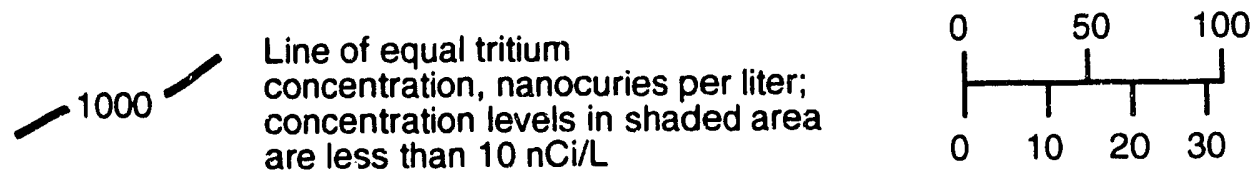

Scale in Meters

FIGURE 4.2 Extent of the Tritium Plume in Glacial Tills under Plot $M$ in the 1980s 


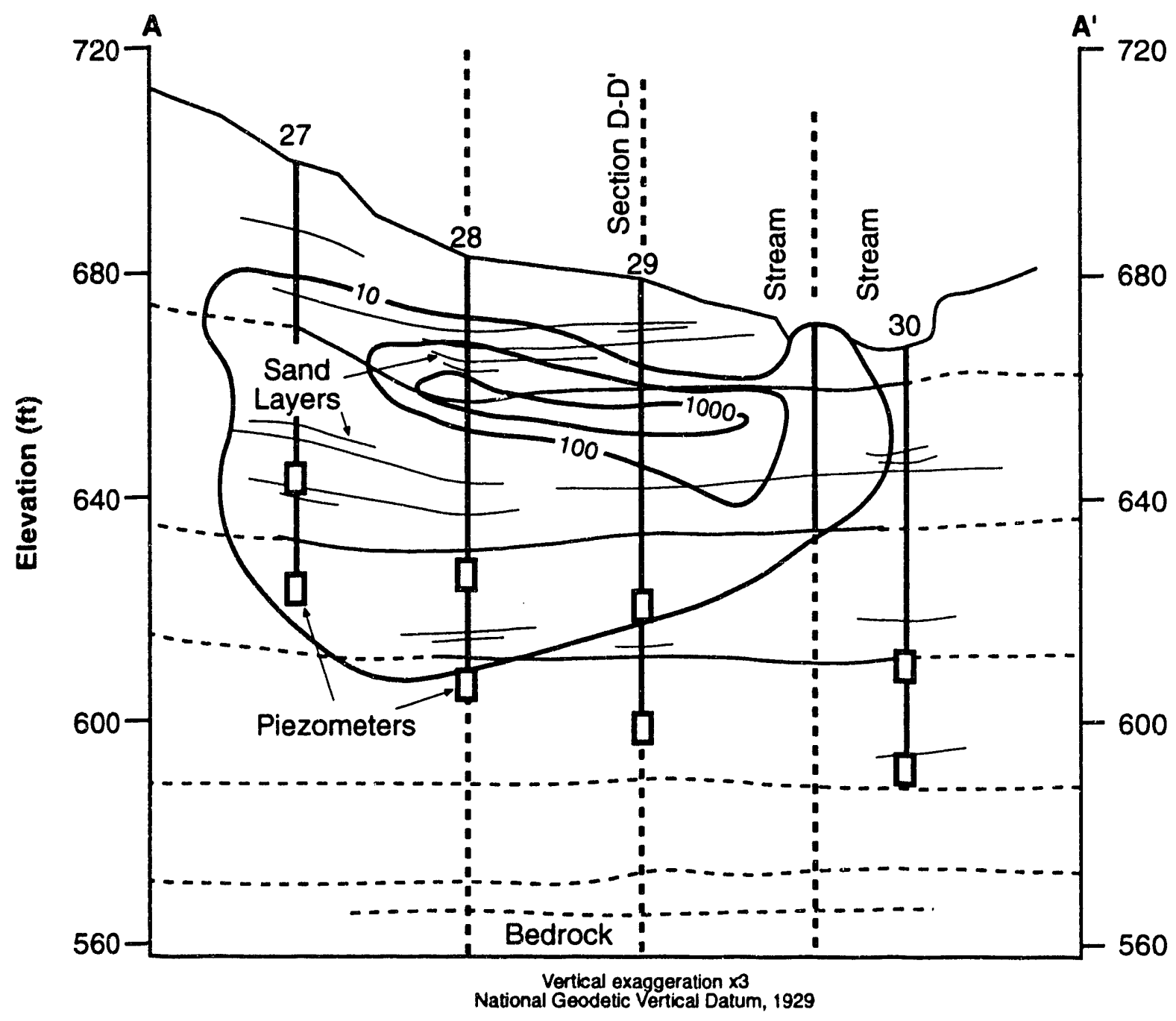

Scale in Feet
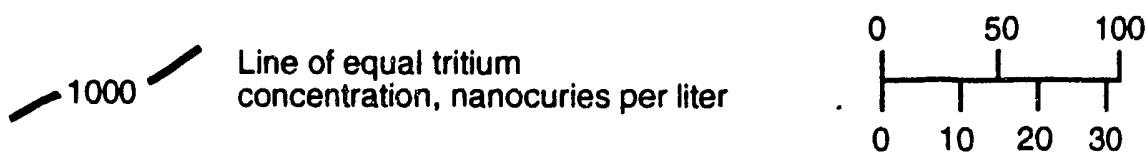

Scale in Meters

FIGURE 4.3 Extent of the Tritium Plume in Glacial Tills about $200 \mathrm{ft}$ North of the Northern Boundary of Plot $M$ in the Early 1980s (Source: Olimpio 1984) 

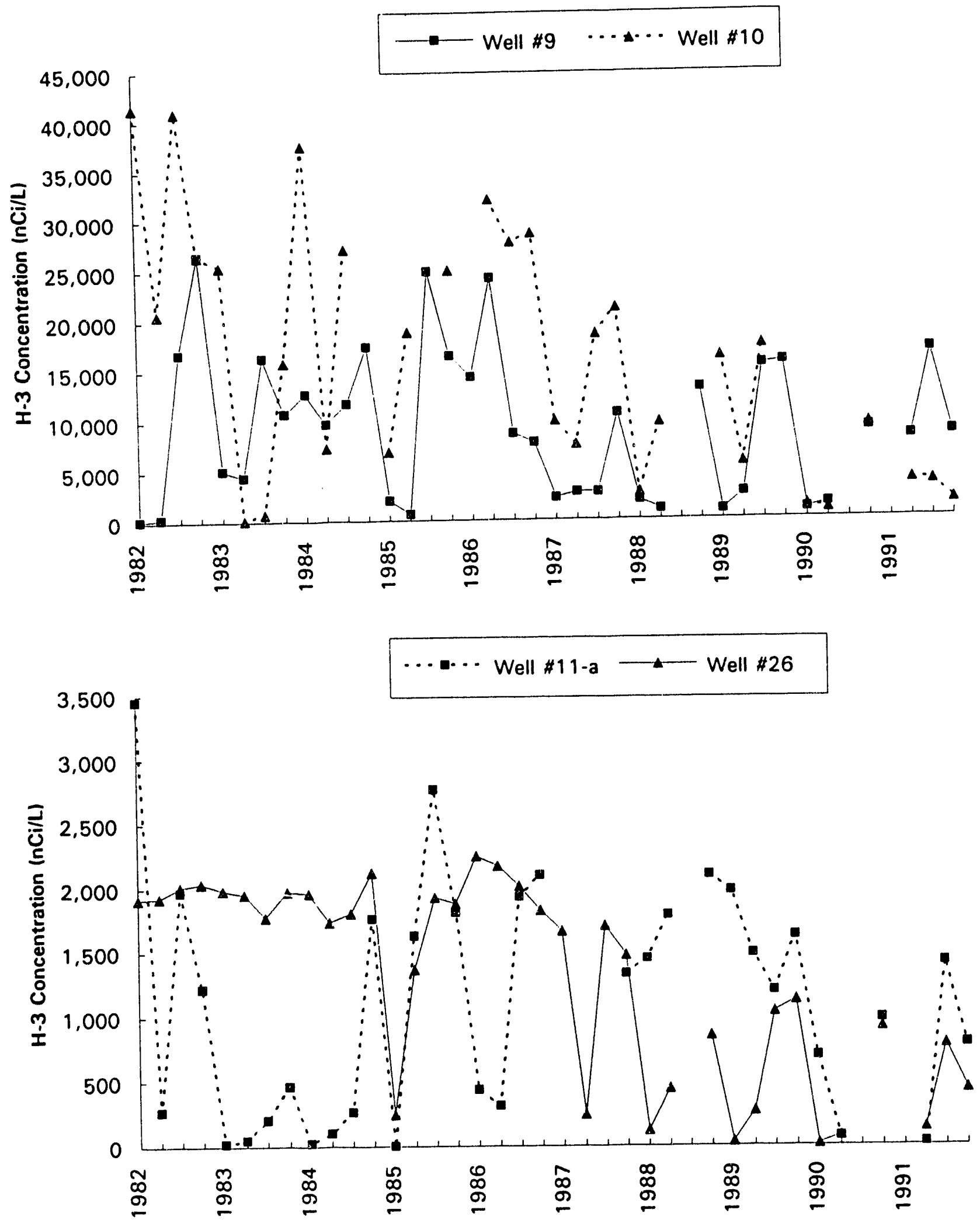

FIGURE 4.4 Average Quarterly Data on Tritium Concentrations in Groundwater from Wells 9, 10, 11-a, and 26 (shallow wells in tills) (Sources: Data from Golchert and Sedlet 1984a, 1984t, 1985, 1986; Golchent 1987, 1988, 1989; 1990, 1991, 1992) 


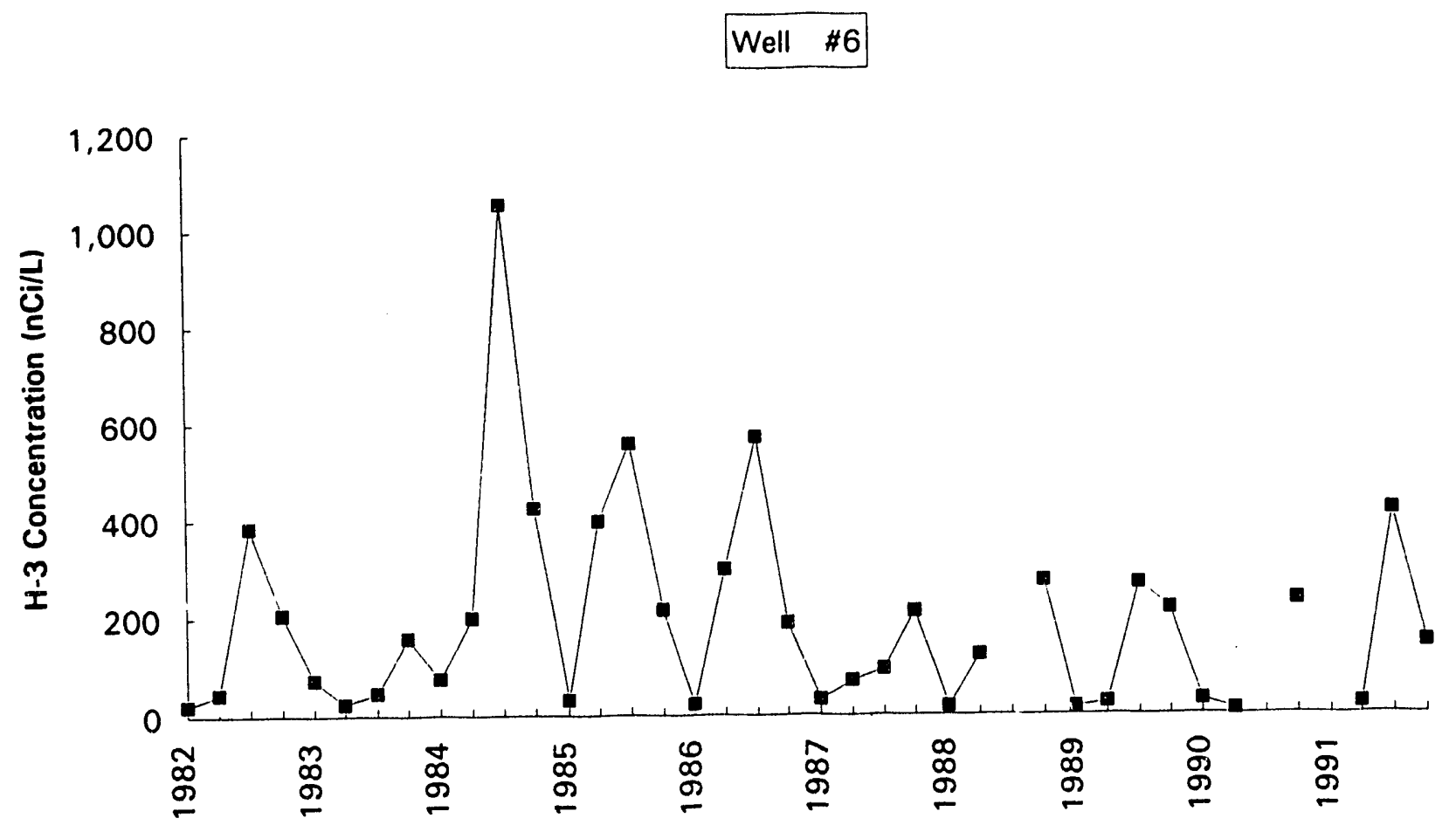

FIGURE 4.5 Average Quarterly Data on Tritium Concentrations in Groundwater from Well 6 (shallow well in tills) (Sources: Data from Golchert and Sedlet 1984a, 1984b, 1985, 1986;Golchert 1987, 1988, 1989, 1990, 1992)

For other shallow wells away from Plot $M$ or near its western boundary, such as wells $1,4,5$, and 28, the tritium level did not often show dramatic seasonal changes. Except for well 4 , tritium levels in groundwater have declined slightly or stabilized in the last few years (Figure 4.6). Higher tritium levels occur in wells closer to the plot. For example, wells 1 and 4 have tritium levels ranging from 1,500 to $2,000 \mathrm{nCi} / \mathrm{L}$, while wells 5 and 28 have tritium levels about 60 and $170 \mathrm{nCi} / \mathrm{L}$, respectively. It should be noted that the tritium level in well 4 increased suddenly in 1989 and has remained between 1,300 and 2,000 $\mathrm{nCi} / \mathrm{L}$ since then (Figure 4.7).

For the deep wells (11-c, 24, 35 and 36), the tritium levels in groundwater declined in the last few years (Figure 4.8). Higher levels of tritium were found in wells farther away from the plot. For example, well 35 , located about $100 \mathrm{ft}$ from the northern boundary of the plot, consistently had higher levels of tritium than the other three deep wells from 1982 to 1990. In the 1991 data, only well 36 had slightly higher readings than well 35.

Only one well (11-b) is used to monitor the groundwater from the middle section of the glacial tills, perhaps because the middle section is an unsaturated zone. Groundwater is present locally in a few sand lenses or layers. Nevertheless, the groundwater taken from 


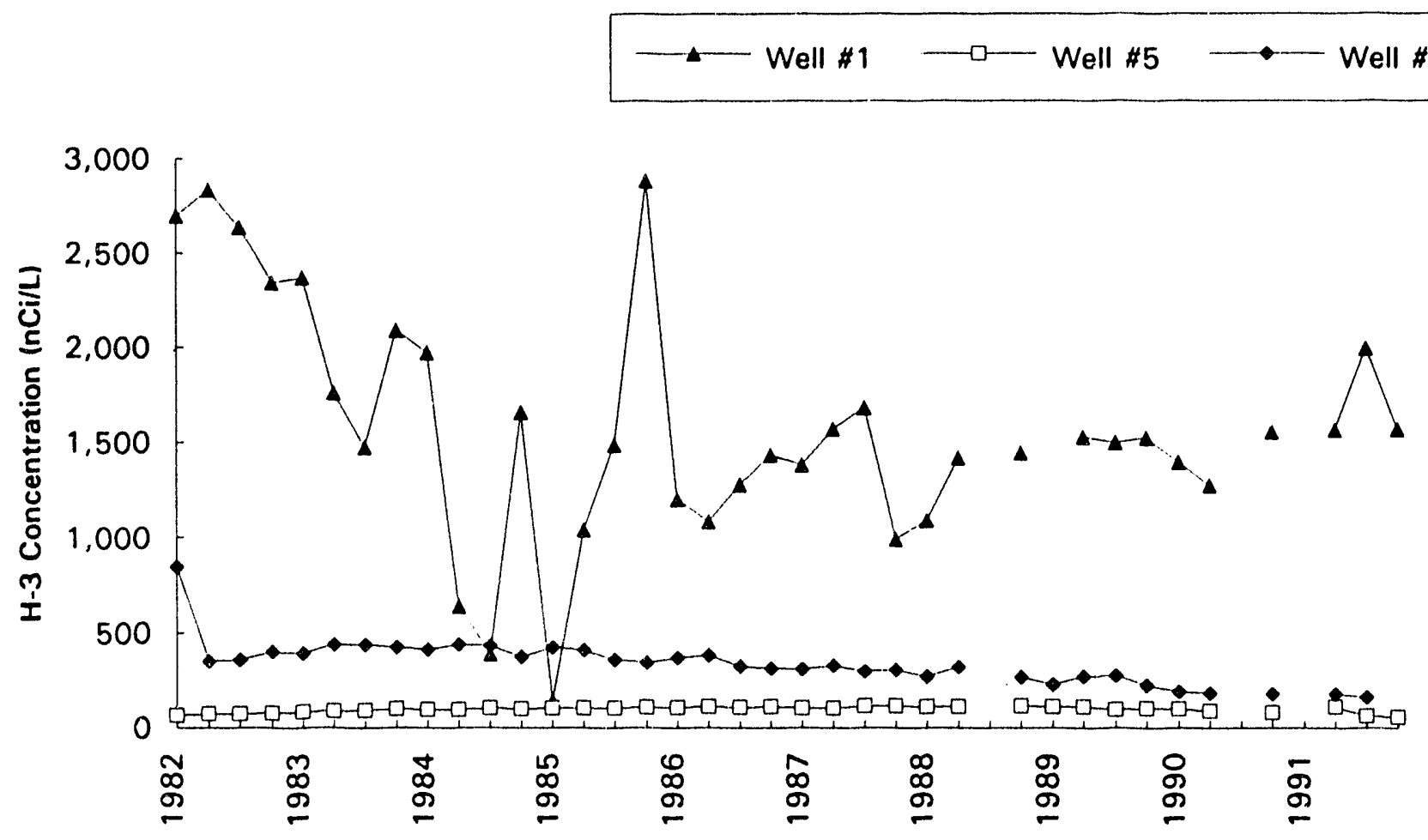

FIGURE 4.6 Average Quarterly Data on Tritium Concentrations in Groundwater from Wells 1, 5, and 28 (shallow wells in tills) (Sources: Data from Golchert and Sedlet 1984a, 1984b, 1985, 1986; Golchert 1987, 1988, 1989, 1990, 1992)

that well had a tritium level of about $25,000 \mathrm{nCi} / \mathrm{L}$ in 1985 and about $10,000 \mathrm{nCi} / \mathrm{L}$ in 1991 . Well 11-b has been monitored for about four years on an irregular schedule.

Given current data, the pattern of the tritiated groundwater near Plot $M$ is difficult to establish. The difficulties are caused by several factors. First, the hydrogeology of the area is characterized by series of sand lenses and layers within the clayey tills. The movement of the tritiated water is complicated by the geometry of these sand bodies. Second, only the upper and lower parts of the till were monitored, while the middle part of the till is unsaturated. However, the middle part of the till may be locally saturated (e.g., in sand lenses) during part of the year. Third, the monitoring wells near the plot might have been screened in different sand lenses or layers. This possibility makes it very difficult to correlate the groundwater quality data among wells. Last, groundwater samples are taken without purging, which reduces the reliability of the data.

\subsubsection{Dolomite Aquifer}

The groundwater has been sampled and analyzed for the Surveillance and Maintenance Program since 1978. In addition to three wells in the picnic area, 13 bedrock wells currently exist (Figure 2.7), one on Site A and another south of Plot M. The rest of the 


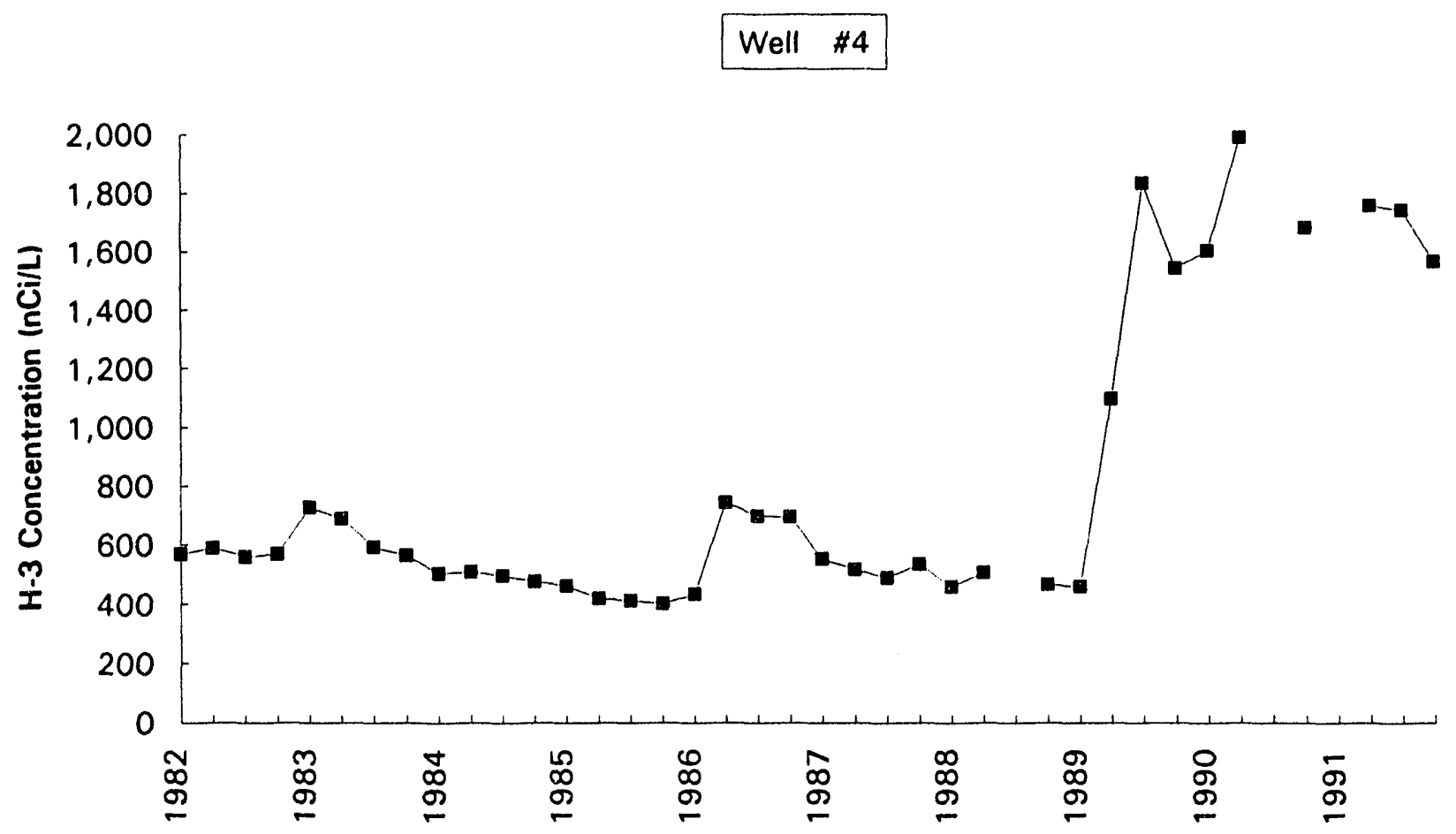

FIGURE 4.7 Average Quarterly Data on Tritium Concentrations in Groundwater from Well 4 (shallow well in tills) (Sources: Data from Golchert and Sedlet 1984a, 1984b, 1985, 1986; Golchert 1987, 1988, 1989, 1990, 1992)

wells are located between Plot $M$ and the Red Gate Woods picnic area. They were installed in 1976 (DH-1 to DH-4), 1982 (DH-5), 1983 (DH-10), and 1986 (DH-11 through DH-17) after tritium was found in a supply well in the picnic area in 1973. Wells DH-6 through DH-9 were originally designed to monitor the dolomite aquifer but have since collapsed (Golchert 1990, 1991). It is difficult to determine the source of the water in the wells. All 17 wells were sampled and analyzed for tritiated water. The results were published by the USGS (Nicholas and Healy 1988) and ANL (annual reports on surveillance of Site A and Plot M).

Nicholas and Healy (1988) have identified two plumes with low levels of tritium (less than $28 \mathrm{nCi} / \mathrm{L}$ ) in the dolomite aquifer (Figure 4.9). One is near Plot M. The plume shown in Figure 4.9 was constructed by using data from wells DH-1 through DH-4. They are open rock wells and have no screens. Wells $\mathrm{DH}-1, \mathrm{DH}-2$, and $\mathrm{DH}-3$ have been installed in dolomite over intervals of 40,41 , and $45 \mathrm{ft}$, respectively, while Well DH-4 has been installed in dolomite over an interval of about $164 \mathrm{ft}$ (Golchert et al. 1983).

The second tritium plume in the dolomite aquifer is located near the picnic area (Figure 4.9). Its center is near well DH-11. Tritium levels in well DH-11 have declined from about $10 \mathrm{nCi} / \mathrm{L}$ in 1986 to about $4 \mathrm{nCi} / \mathrm{L}$ in 1991 . South of well $\mathrm{DH}-16$ (Figure 2.7), the tritium level in the dolomite groundwater has always been less than $0.2 \mathrm{nCi} / \mathrm{L}$. 
54
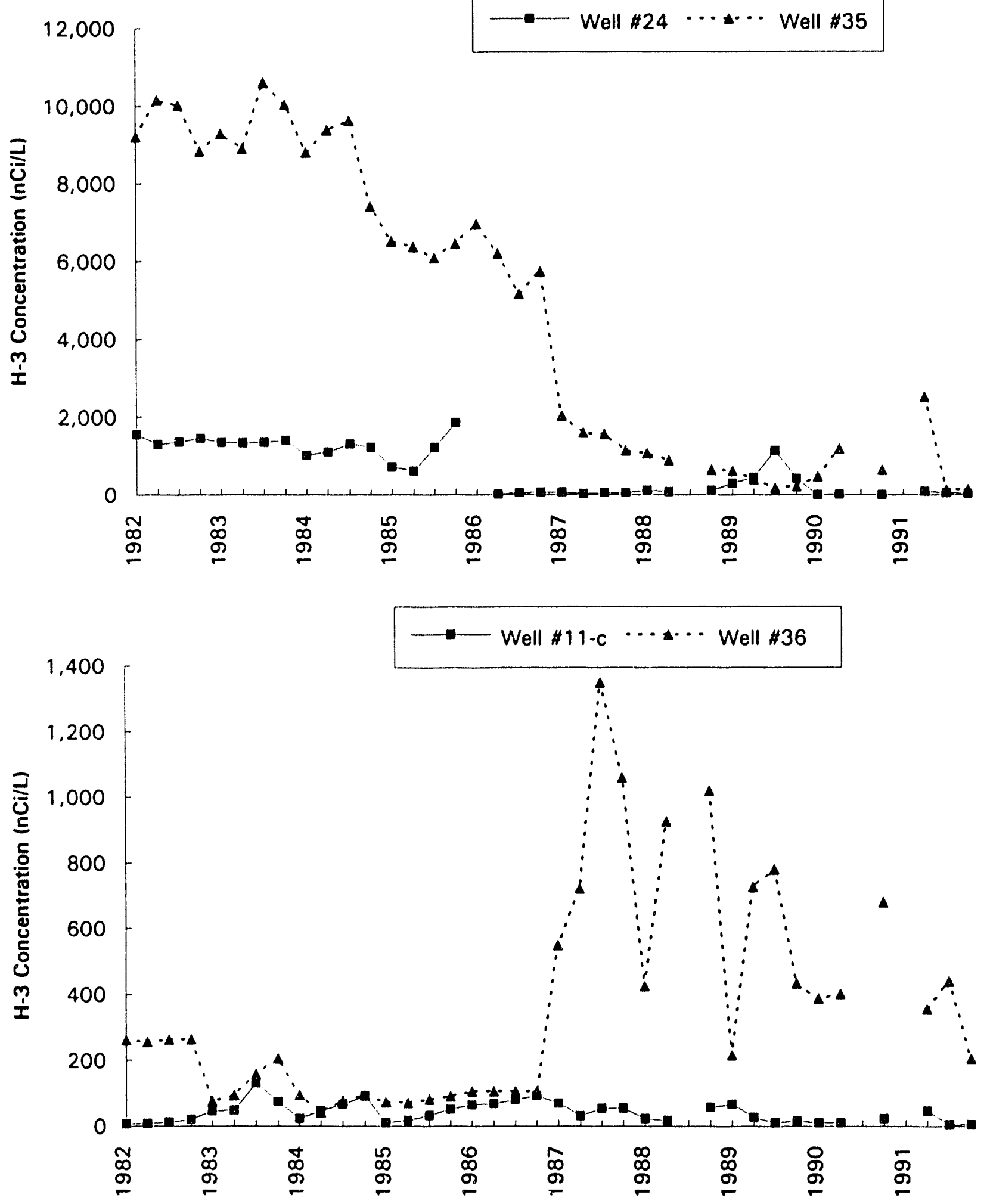

FIGURE 4.8 Average Quarterly Data on Tritium Concentrations in Ground water from Wells 11-c, 24, 35, and 36 (deep wells in tills) (Sources: Data from Golchert and Sedlet 1984a, 1984b, 1985, 1986; Golchert 1987, 1988, 1989, 1990, 1992) 


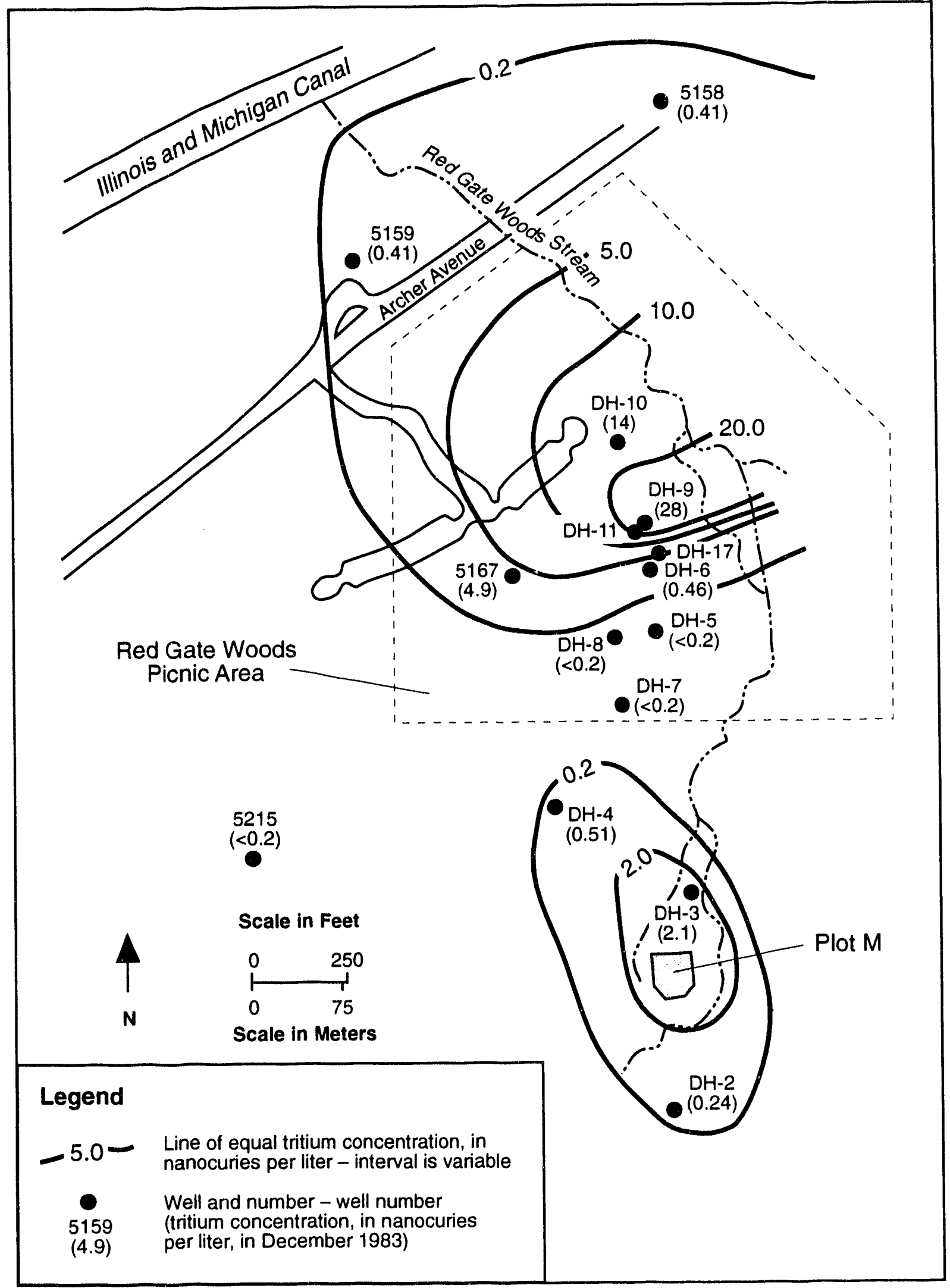

FIGURE 4.9 Extent of the Tritium Plume in the Bedrock Aquifer near Plot M (Source: Nicholas and Healy 1988) 


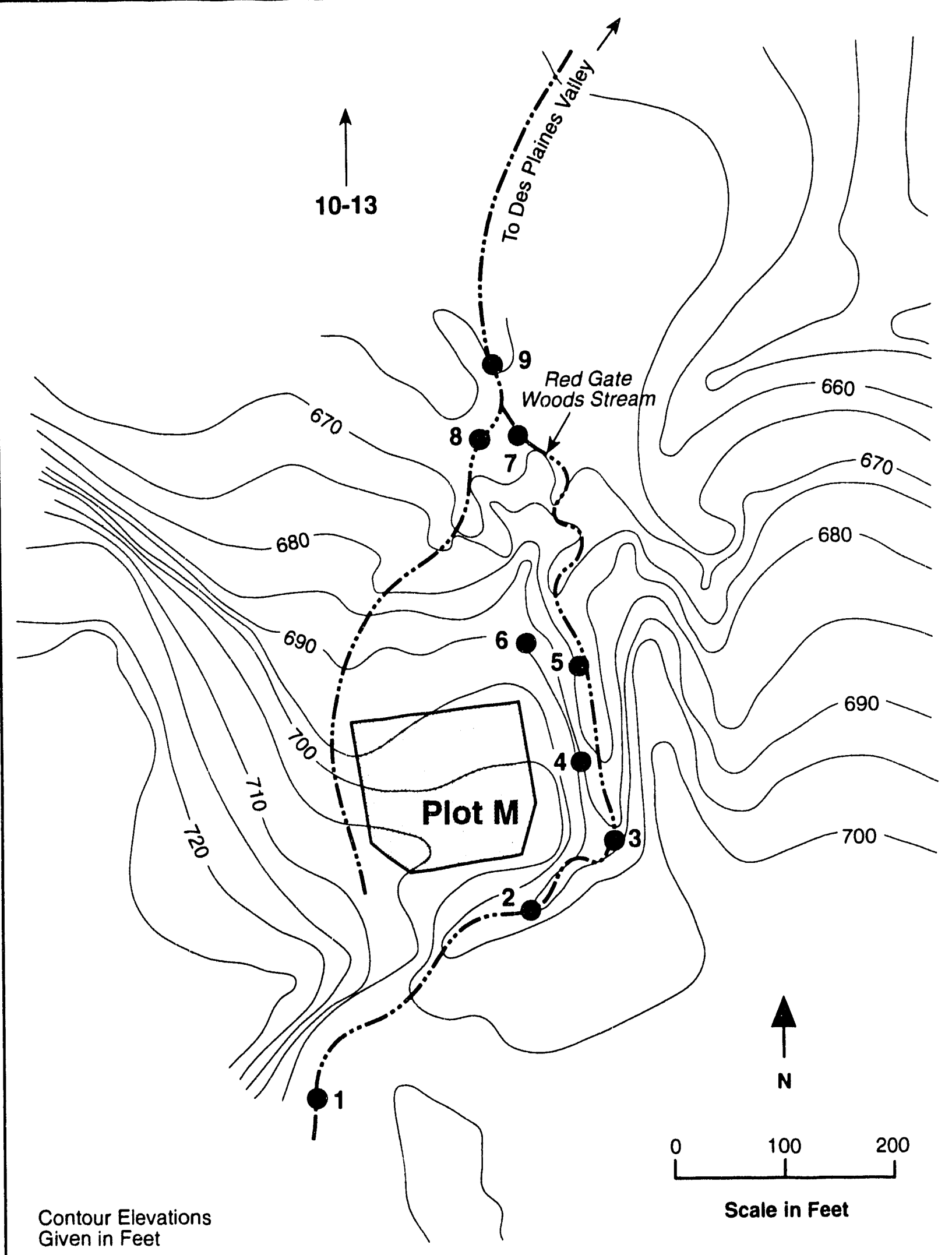

FIGURE 4.10 Sampling Locations for Surface Water and Sediment near Plot $M$ (Source: Golchert 1992) 
Groundwater samples from wells DH-2, DH-3, and DH-4 were analyzed for TCL constituents (metals, volatile organic compounds [VOCs], semivolatile organic compounds [SVOCs], and polychlorinated biphenyls [PCBs]/pesticides) in the last quarter of 1991. According to Golchert (1992), no TCL constituents were identified above detection limits in these wells. Since 1991 was the only time that TCL analytes were analyzed, it is difficult to determine the significance of these results.

The three wells in the Red Gate Woods picnic area are used to monitor groundwater. Tritium levels in well 5167 decreased from about $11 \mathrm{nCi} / \mathrm{L}$ in 1973 to less than $0.21 \mathrm{nCi} / \mathrm{L}$ in 1991. The tritium levels in well 5159 have fluctuated between 0.2 and $2.3 \mathrm{nCi} / \mathrm{L}$ over the last 10 years. In the newly installed well 5160 , which tapped groundwater $20 \mathrm{ft}$ below the till/dolomite interface, the tritium levels increased slightly from less than $0.2 \mathrm{nCi} / \mathrm{L}$ in 1988 to about $0.6 \mathrm{nCi} / \mathrm{L}$ in late 1991 .

\subsubsection{Surface Water and Sediment}

In the springs of 1976 and 1977, surface-water samples were taken from various points around and downstream of Plot M (Figure 4.10). These samples were analyzed for tritium. Low levels of tritium were found; in fact, the 1976-1977 levels were one to two orders of magnitude lower than the levels in the samples collected in 1954. For example, the highest concentration analyzed in 1977 was $17 \mathrm{nCi} / \mathrm{L}$, while the concentration of the sample taken in 1954 from the same location was $2,010 \mathrm{nCi} / \mathrm{L}$. The highest contamination was found in the area immediately below Plot $M$. The tritium concentration in surface water collected east of Plot M in the Red Gate Woods Stream was between 200 and $300 \mathrm{nCi} / \mathrm{L}$ in the spring during the early 1980 s and about $40 \mathrm{nCi} / \mathrm{L}$ in 1991 . Also, the tritium level was one order of magnitude lower in fall than in spring.

Seepage water from a seep (location 6, Figure 4.10) next to the plot was sampled and found to have high levels of tritium. A review of the annual surveillance reports for 1982 to 1991 revealed that the tritium concentration in the water emerging from the seep has varied greatly. It appears that the tritium concentration is highly dependent on the amount of water flowing from the seep and, thus, is dependent on the amount of precipitation in the area. Higher levels were found in the spring than in the fall. This pattern is consistent with the pattern found in the other surface-water samples. In 1990 and 1991, the tritium levels in the seep fluctuated from 60 to $370 \mathrm{nCi} / \mathrm{L}$ (Golchert 1990, 1991).

Sediment sample data for location 1 (upstream) and location 9 (downstream), shown in Figure 4.10, were reviewed for trends in two isotopes, plutonium-239 and strontium-90. The concentrations of these isotopes vary yearly and appear to depend on the amount of water flowing in the stream. Strontium-90 concentrations do not follow a particular pattern, and conclusions are difficult to make on the basis of these data. Plutonium-239 concentrations downstream from Plot $\mathrm{M}$ are approximately four times higher than the upstream values. In 1989 , the upstream value for plutonium- 239 was $0.0091 \mathrm{pCi} / \mathrm{g}$, and the 
downstream value was $0.0400 \mathrm{pCi} / \mathrm{g}$. In 1990 , the values were 0.0105 and $0.0439 \mathrm{pCi} / \mathrm{g}$, respectively; and in 1991 the values were 0.0085 and $0.0404 \mathrm{pCi} / \mathrm{g}$, respectively (Golchert 1990).

\subsection{SITE A}

\subsubsection{Former Buildings}

When Site A was decommissioned in 1956, most buildings at the site were surveyed for radioactivity (McKinley 1956). The survey covered all floors, horizontal surfaces, and walls up to approximately $7 \mathrm{ft}$. However, the grounds surrounding the buildings and the outside surfaces of the buildings were not surveyed. The results of the survey are presented in Section 1.2.1.4.

\subsubsection{Soil}

In 1976, an extensive surface soil sampling was done over an area of about $650 \mathrm{ft} \times 700 \mathrm{ft}$ where Buildings A through D had been located (Golchert and Sedlet 1977). A sampling grid was established, with $25-\mathrm{ft}$ intervals near the CP-3 reactor and $50-\mathrm{ft}$ intervals outside that area. Each grid point was sampled to a depth of 6 in., resulting in a total of 105 samples (Figure 4.11). The samples contained a variety of materials ranging from gravel and building rubble to black humus soil. All samples were analyzed for nonvolatile alpha and beta activity and for gamma-ray emitters (e.g., antimony-125, cesium-137, cobalt-60, and europium-155) by gamma-ray spectrometry. Soil moisture extracted from the samples was analyzed for tritium.

The results of the 1976 soil sampling are shown in Figure 4.11. In summary, about $90 \%$ of the 105 samples contained normal amounts of gamma-ray emitters (Golchert and Sedlet 1977). Seventeen samples had cesium-137 concentration higher than $1.0 \mathrm{pCi} / \mathrm{g}$, the average fallout concentration. The maximum cesium-137 concentration level in the soils was $5.55 \mathrm{pCi} / \mathrm{g}$. All samples had europium-155 and antimony-125 levels below their detection limit of $0.05 \mathrm{pCi} / \mathrm{g}$, except one. That sample and two other samples contained cobalt-60 at levels slightly above the detection limit of $0.05 \mathrm{pCi} / \mathrm{g}$. Total alpha activity in all samples ranged from 7 to $39 \mathrm{pCi} / \mathrm{g}$, while total beta activity ranged from 19 to $73 \mathrm{pCi} / \mathrm{g}$. In the tritium analysis, 9 of the 12 samples tested had concentrations higher than the detection limit of $0.2 \mathrm{nCi} / \mathrm{L}$. Most of the samples that had above-background levels of cesium-137 and tritium were located in a southeast-oriented belt that extended from the Fire Station (a previous garage) to the southeastern part of the Well House (Figure 4.11).

In addition to the surface soil sampling program, four borings, each 50 ft from the buried reactor shield site, were drilled to a depth of about $60 \mathrm{ft}$ (Figure 4.12). Sixteen soil samples were taken from each core for analysis for tritiated water and gamma-ray-emitting 


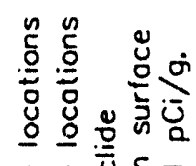

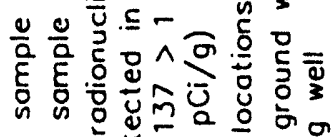

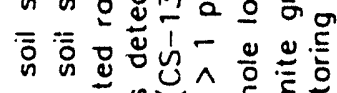

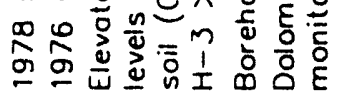
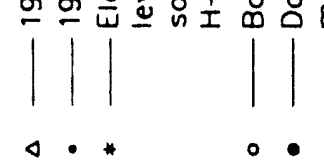

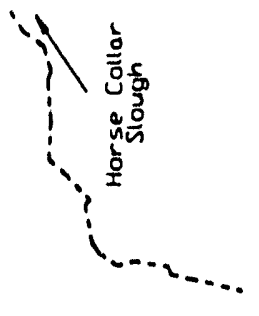

? 


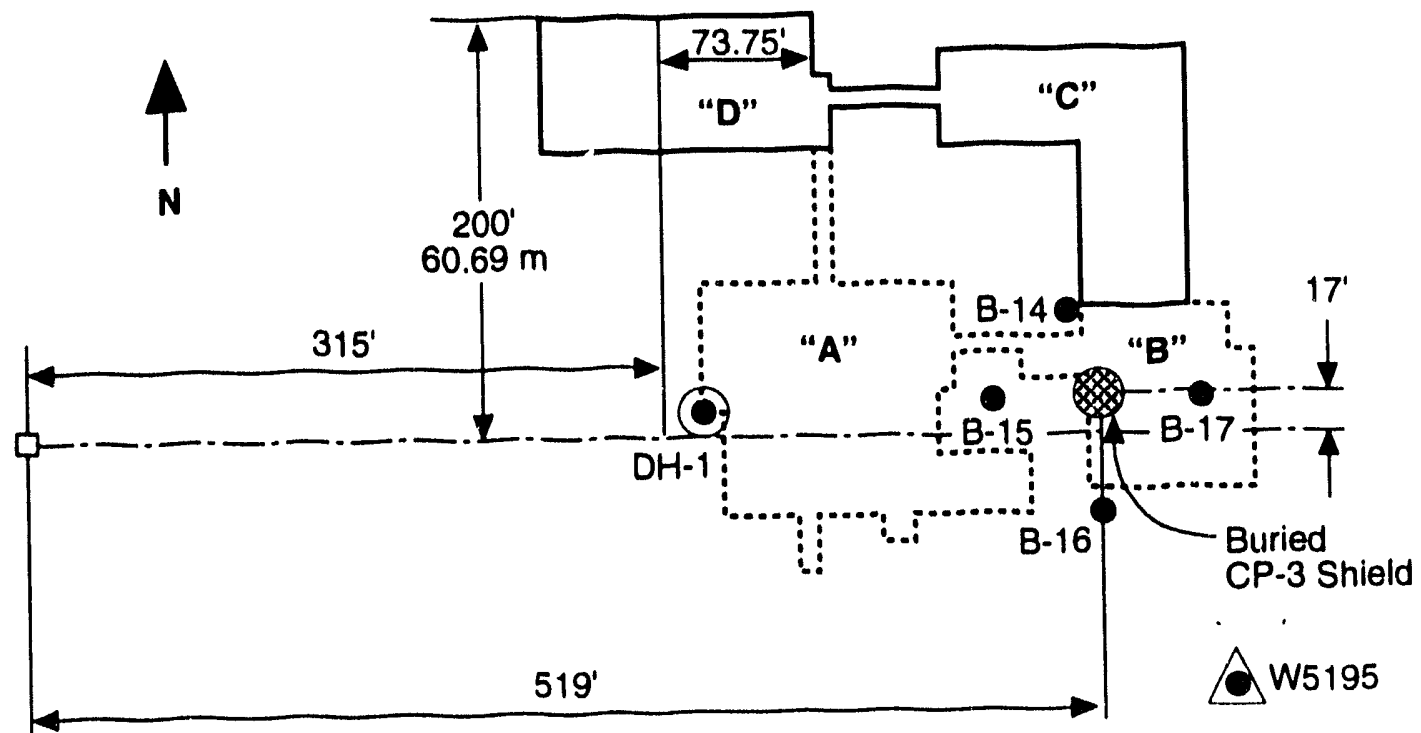

FIGURE 4.12 Locations of Soil Borings, Dolomite Groundwater Well (DH-1), and Buried Reactor Shield at Site A (Source: Golchert and Sedlet 1977)

nuclides. Of the 16 samples, 4 from each core were also analyzed for strontium-90, uranium, and plutonium. Nonvolatile alpha and beta activity were measured.

Golchert and Sedlet (1977) provided the radiochemical analysis results for the above samples. In summary, of the parameters analyzed, only the tritium level was significantly higher than background in all four cores. The tritium level ranged from less than $0.2 \mathrm{pCi} / \mathrm{L}$ to $444 \mathrm{nCi} / \mathrm{L}$ in soil pore waters. The pattern of the tritium distribution varied among cores, with the highest being west and then south of the burial location, and the lowest east. Each core shows an increase in tritium concentration with depth to about $15 \mathrm{ft}$ below the surface. The concentration then decreases to a minimum at about 40 to $50 \mathrm{ft}$. Another tritium concentration peak appears near the bottom of the core.

In 1978, six more surface soil samples were obtained just south of Laboratory B at Site A (Figure 4.11) to verify the 1976 survey results. The samples were analyzed by gammaray spectrometry, and the moisture was analyzed for tritium. Two of the six surface soil samples contained cesium-137 above fallout levels. The same two samples had tritium levels of 5.37 and $3.12 \mathrm{nCi} / \mathrm{L}$, an order of magnitude higher than in others. The two samples came from the same general area where anomalous cesium-137 levels were found in 1976 (Golchert et al. 1983) (Figure 4.11).

In 1987, three soil-gas samples were taken near the UST area (tank suspect area 2) in the northeastern part of Site A (ORNL 1989). Each sample contained $1 \mathrm{~L}$ of soil gas withdrawn at a depth of $2.5 \mathrm{ft}$ below the surface. Each sample was analyzed for benzene, carbon tetrachloride, chloroform, ethyl acetate, methyl isobutyl ketone, methylene chloride, $\mathrm{N}, \mathrm{N}$-dimethylformamide, tetrahydrofuran, and trichloroethylene. Carbon tetrachloride, estimated to be as high as $6,400 \mathrm{ng} /$ tube, was found in one sample. Other volatiles included 
chloroform at 1,500 and $1,700 \mathrm{ng} /$ tube in two of the samples; N,N-dimethylformamide at $33,000 \mathrm{ng} /$ tube in one sample; and trichloroethylene estimated at 3,400 $\mathrm{ng} / \mathrm{tube}$ (ORNL 1989).

Surface soil samples were also collected from the drain field and two suspect lead foundry areas. The suspect lead foundry areas, one near the northern side of Laboratory $\mathrm{H}$ and the other near the Old Lead Foundry (Figure 1.3), were sampled at seven locations over a depth interval from 0.5 to $1.5 \mathrm{ft}$. The samples were analyzed for lead. Three of the samples contained lead above the detection limit, ranging from 75 to $141 \mathrm{mg} / \mathrm{kg}$ (ORNL 1989). For the drain field, six samples were collected at three locations over two depth intervals, from 0 to $2.5 \mathrm{ft}$ and from 2.5 to $5.0 \mathrm{ft}$. No elevated levels of metal or extractable organics were found. In addition, very low levels of methylene chloride (the maximum reading was estimated at $0.969 \mathrm{mg} / \mathrm{kg}$ ) and acetone (the maximum level was $0.035 \mathrm{mg} / \mathrm{kg}$ ) were detected (ORNL 1989).

In the summer of 1990 , a radiological survey was carried out at Site A as part of a Phase 1 study of Site A/Plot M (Figure 4.13). The Phase 1 study included areas of Site A itself, four suspect areas that were identified in the preliminary study from old aerial photographs, roads and trails near Site A/Plot M, areas adjacent to those roads and trails (out to $10 \mathrm{ft}$ on either side), 10 locations in Red Gate Woods picnic area, 4 off-site locations, and a septic drain field northeast of Site A. Walkover gamma surface scans were done with sodium iodide scintillation detectors, and visual inspections were conducted at 3 - to 5 -ft intervals. Additional gamma-ray measurements, including exposure rates at contact and at $1 \mathrm{~m}$ above the surface, were made at locations where the gamma scans identified elevated direct radiation. At these locations, soil was also sampled to as much as 18 in. from the surface and analyzed by gamma spectrometry. The results of this survey are presented in Table 4.4.

The 1990 radiological survey and soil sampling results (ORAU 1990, 1991) showed that no significant departures from the background radiation level, which ranges from 6 to $10 \mu \mathrm{R} / \mathrm{h}$ (ORAU 1990), were found near the ground surface in the drain field northeast of Site $A$, the Red Gate Woods picnic area, or suspect areas 1 and 2. Plot $M$ has slightly higher levels of gamma radiation (ranging from 9 to $15 \mu \mathrm{R} / \mathrm{h}$ at the surface and 9 to $13 \mu \mathrm{R} / \mathrm{h}$ at $1 \mathrm{~m}$ above the surface) than the background levels.

On Site A, gamma scans identified four locations of elevated contact radiation. Of the four locations, three are located in areas south and southeast of Laboratory A (Figure 4.13). A source of the radiation was identified at two of the four locations: one was a piece of graphite containing cesium-137 and europium-152/154/155 contamination; the other was an object containing about $58 \mu \mathrm{Ci}$ of radium-226. The sources were later removed. The contaminant sources at the other two locations (grid coordinates 50S, 0 and 150S, 120E; Figure 4.13) appeared to be distributed. Soil samples taken at the 50S, 0 grid coordinate contained cesium-137 at a level of $129 \mathrm{pCi} / \mathrm{g}$, strontium-90 at $1,340 \mathrm{pCi} / \mathrm{g}, \mathrm{Pu}-238$ at $0.6 \mathrm{pCi} / \mathrm{g}$, and plutonium-239/240 at $2.0 \mathrm{pCi} / \mathrm{g}$. Soil samples taken at the $150 \mathrm{~S}, 120 \mathrm{E}$ grid coordinate had natural uranium at a level of $547 \mathrm{pCi} / \mathrm{g}$ and strontium-90 at $15.1 \mathrm{pCi} / \mathrm{g}$. 


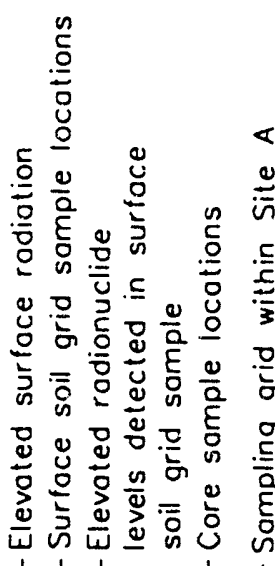

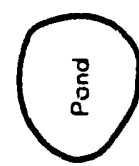

글<smiles>[Te][Te][Te]</smiles>

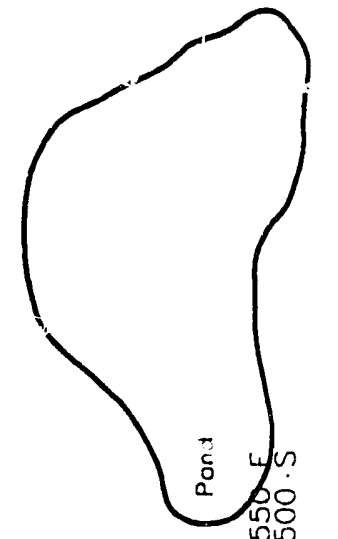

尊 
TABLE 4.4 Background Exposure Rates and Levels of Gamma-Emitting Radionuclides in Surface Soil near Site A

\begin{tabular}{ll}
\hline Parameters & Range \\
\hline Exposure rate at surface contact & 6 to $10 \mu \mathrm{R} / \mathrm{h}$ \\
Exposure rate at $1 \mathrm{~m}$ above surface & 6 to $10 \mu \mathrm{R} / \mathrm{h}$ \\
\hline Cesium-137 & 0.2 to $1.1 \mathrm{pCi} / \mathrm{g}$ \\
Potassium-40 & 7.4 to $24.4 \mathrm{pCi} / \mathrm{g}$ \\
Radium-226 & 0.4 to $1.7 \mathrm{pCi} / \mathrm{g}$ \\
Thorium-232 & 0.6 to $1.4 \mathrm{pCi} / \mathrm{g}$ \\
Uranium-235 & 0.1 to $0.4 \mathrm{pCi} / \mathrm{g}$ \\
Uranium-239 & $<1.1$ to $2.9 \mathrm{pCi} / \mathrm{g}$ \\
\hline
\end{tabular}

Source: ORAU (1990).

In suspect area 3, nine locations showed elevated gamma radiation in the gamma scan survey. Most of the nine locations are in the southern part of the suspect area (Figure 4.13). The anomalies in four of the nine locations were found to be caused by discrete objects, which were later removed. Subsequent soil samples confirmed contamination at two of the remaining five locations (with 520 and $22.6 \mathrm{pCi} / \mathrm{g}$ uranium-238), but not at the other three.

The locations of the elevated gamma radiation in the southern part of suspect area 3 are consistent with its historical use. From several 1940s aerial photographs, most of activities in the suspected area were concentrated in the southern half. Historically, the activities in suspect area 4 (see next paragraph) were concentrated in the eastern part.

In suspect area 4, five locations showed elevated gamma radiation in the gamma scan survey (Figure 4.13). Later soil sampling confirmed the radiation contamination in four of the five locations. Levels of natural uranium (with the standard ratio of U-234, U-235, and $\mathrm{U}-238$ ) ranged from 305 to $888 \mathrm{pCi} / \mathrm{g}$ in the first 6 in. of surface soil. Contamination in the soil extended to a depth of at least 18 in.

Systematic grids were made covering suspect areas 1-4, the drain field, Plot $M$, and Site A. Surface soil from each grid intersection was sampled to a depth of 6 in. (Figure 4.13). The samples were analyzed by gamma spectrometry. Some of the systematic samples were collected into groupings of 6 to 10 samples and analyzed for tritium, strontium-90, uranium, and plutonium. 
Grid samples from suspect areas 1 and 2, Plot M, and most of Site A have gammaemitting radionuclides in concentrations comparable to the background levels. However, two samples from suspect area 3 (Figure 4.13) contained uranium-238 at 10.8 and $17.6 \mathrm{pCi} / \mathrm{g}$. Two grid samples from suspect area 4 had uranium-238 at 83.6 and $32.3 \mathrm{pCi} / \mathrm{g}$ (Figure 4.13). Several grid samples from Site A were found to have cesium-137 and uranium-238 concentrations slightly above background levels. Their locations were not reported (ORAU 1991). The results for the grid samples from the drain field are also unavailable.

Surface soil samples were taken to a depth of 4 to $6 \mathrm{ft}$ from boreholes in different areas. They were analyzed for radionuclides by gamma spectrometry. They include two samples from an area about $200 \mathrm{ft}$ south of Building B at Site A, three samples from the drain field northwest of the site, five samples from suspect area 1, four samples from suspect area 2, six samples from suspect area 3, and four samples from suspect area 4 (Figure 4.13).

For all samples from the boreholes, the uranium concentrations are not significantly different from background levels (ORISE 1993). For example, the uranium-235 concentration ranges from 0.1 to $0.9 \mathrm{pCi} / \mathrm{g}$, with most of the values falling around $0.4 \mathrm{pCi} / \mathrm{g}$; uranium-238 ranges from below 1.5 to $7.3 \mathrm{pCi} / \mathrm{g}$, and the cesium-137 from below 0.1 to $2.0 \mathrm{pCi} / \mathrm{g}$. However, the boreholes in suspect areas 3 and 4 were not located in the areas of elevated radioactivity that were identified in the surface survey.

\subsubsection{Groundwater}

At Site A, information on groundwater is limited to data from one well (DH-1). The well is at the western margin of Laboratory $A$ and was installed in the dolomite aquifer in September 1976 (Figure 4.12). The well is open in the dolomite for $45 \mathrm{ft}$. Since its installation, groundwater samples have been collected regularly and analyzed for tritium (Golchert and Sedlet 1977).

From 1976 to 1991 , the tritium concentration in the water samples from well DH-1 ranges from less than 0.2 to $0.55 \mathrm{nCi} / \mathrm{L}$. Until 1985 , concentrations commonly exceeded the detection limit of $0.2 \mathrm{nCi} / \mathrm{L}$. Since 1985 , tritium concentrations have been below the detection limit. In August 1991, a water sample from the well was also analyzed for TCL metals, VOCs, SVOCs, and PCBs/pesticides (Golchert 1992). It contained acetone at a level of $700 \mathrm{ppb}$ and methyl ethyl ketone at a level of $140 \mathrm{ppb}$. The methyl ethyl ketone probably

was an impurity of the acetone (Golchert 1993). In the first three quarters of 1992, the acetone levels dropped to between 74 and $84 \mathrm{ppb}$, while the ketone levels ranged from 14 to $21 \mathrm{ppb}$. Other VOCs analyzed in the 1992 samples were below detection limits (Golchert 1993).

\subsubsection{Surface Water and Sediment}

In 1954 and 1955, water samples were taken from four locations in streams at Site A (McKinley 1956). The exact locations of the samples are not clear. The samples contained 
low alpha and beta activities, ranging from 0.0001 to $0.0028 \mathrm{nCi} / \mathrm{L}$ and from 0.0068 to $0.035 \mathrm{nCi} / \mathrm{L}$, respectively. Four sediment samples were also collected at the same time, and their alpha and beta activities ranged from 0.024 to $0.030 \mathrm{nCi} / \mathrm{g}$ and from 0.052 to $0.093 \mathrm{nCi} / \mathrm{g}$, respectively. All activity levels were considered to reflect either background levels or fallout activity (McKinley 1956).

Since 1990, the IDNS has been collecting surface water samples and sediment samples from the water bodies around Site A (Allen 1992, Bianconi 1991). The water bodies include Saganashkee Slough, Horse Collar Slough, and the three small ponds northeast, northwest, and southeast of the site. No elevated or unusual levels of radionuclides have been detected in the pond water samples, except on one occasion when cesium-137 was found at a level of $0.015 \pm 0.003 \mathrm{nCi} / \mathrm{L}$ in the pond northeast of Site $\mathrm{A}$. The level is well below the applicable limit for cesium-137 $(20 \mathrm{nCi} / \mathrm{L})$ established by $n$ llinois for releases to an unrestricted area. In addition, the sediment samples contain radionuclides only slightly above background levels. Bottom-dwelling fish collected from Saganashkee Slough have slightly higher levels of strontium-90 in their bones (a maximum of $0.0022 \pm 0.0002 \mathrm{nCi} / \mathrm{g}$ bone compared to $0.0008 \mathrm{nCi} / \mathrm{g}$ bone at the background level [Bianconi 1991]). Moreover, the concentration of strontium-90 in fish muscle is only 1 to $2 \%$ of that in bone. Normal consumption of these fish (about $6 \mathrm{~kg} / \mathrm{yr}$ ) is unlikely to cause a radiological health hazard (Bianconi 1991).

In addition to sampling the water bodies, IDNS also collects surface runoff samples near the tiles northeast of Site A and near the entrance to the site on Archer Avenue. Since April 1991, the samples collected from the entrance show elevated levels of tritium, ranging from 4.83 to $11.9 \mathrm{nCi} / \mathrm{L}$. However, no unusual levels of other radionuclides were detected. The water samples collected from the confluence of tiles northeast of the site have levels of tritium and potassium -40 ranging from 0.38 to $2.67 \mathrm{nCi} / \mathrm{L}$ and from 0.093 to $0.105 \mathrm{nCi} / \mathrm{L}$, respectively.

\subsection{GROUND PENETRATING RADAR SURVEY}

Following the 1990 Phase 1 survey, a GPR survey was conducted in the spring of 1991 over suspect areas 3 and 4, three of the four tank suspect areas (1-3), and two areas in the south-central part of Site A (Figure 4.14). The objectives of the GPR survey were to delineate subsurface disturbed soil regions that may indicate burial areas, to identify the location of individual subsurface targets that could be drums or other buried objects, and to locate USTs at the site (ORAU 1991).

The GPR survey identified several disturbed regions in the southern part of Site A (ORAU 1991). A few of these areas may be related to building foundations. However, the others, such as the area southeast of the Boiler House and Well House (suspect area 5), are probably related to previous disposal activities, because no facility was built in that area, and the disturbed areas coincide with areas of elevated gamma levels (Figure 4.15). Furthermore, the areas match the general location of a reported disposal pit (DOE 1990) in the southeastern part of Site $A$. 


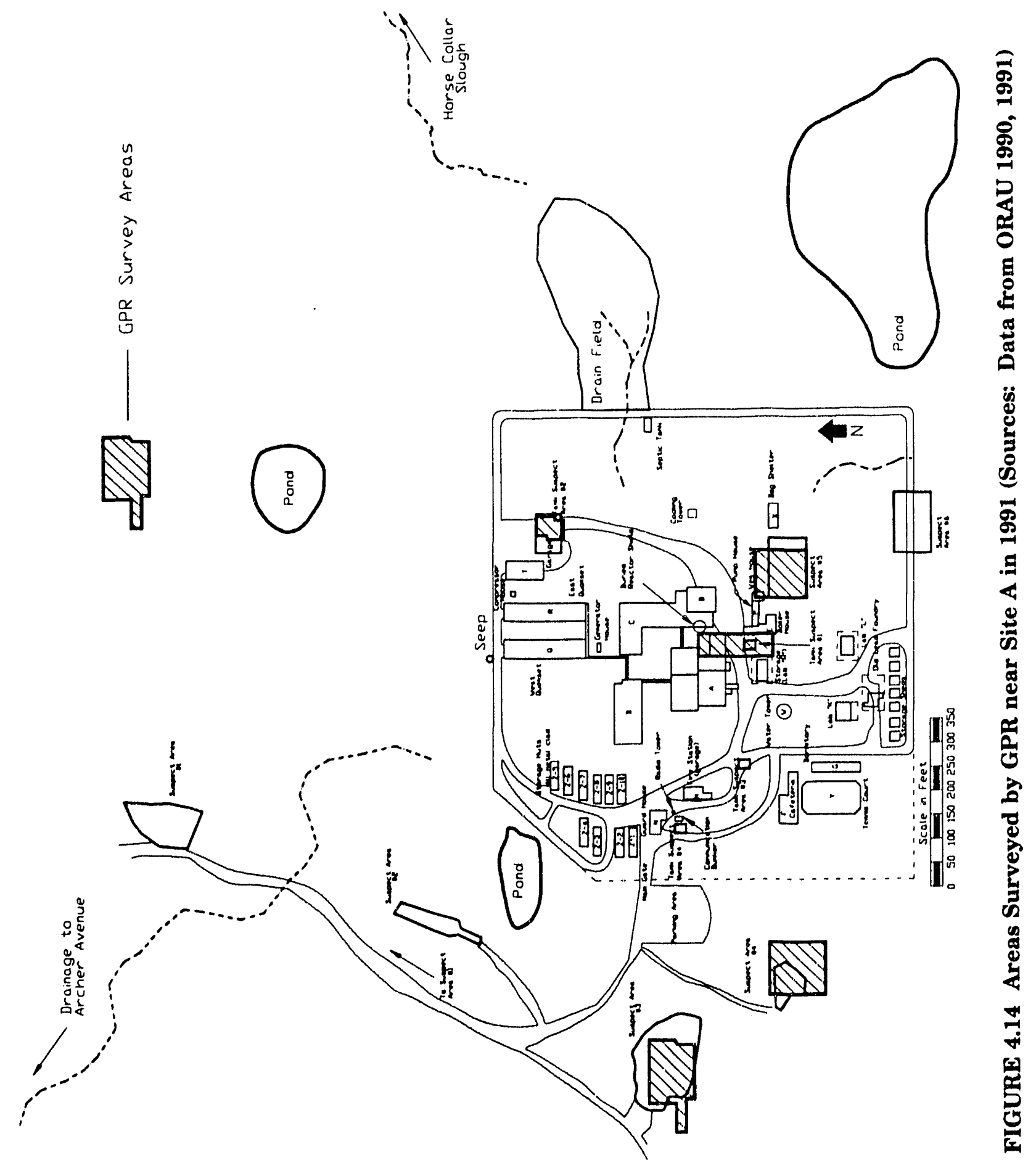




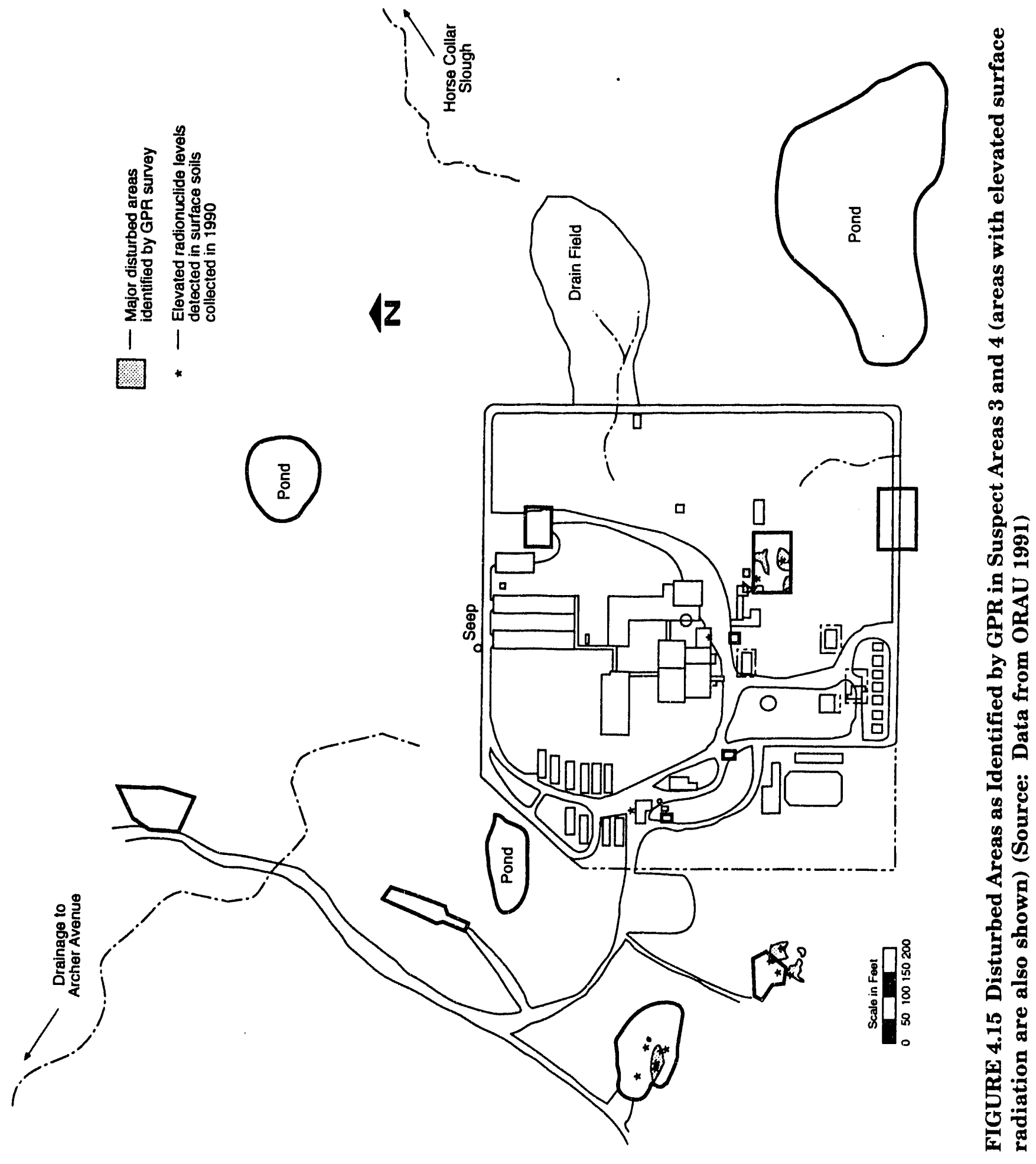


For the disturbed areas near former building sites, the nature of the disturbance is difficult to interpret without additional information. Disturbances in these areas could have been caused by any building construction or decommissioning activities in the past, or by previous disposal activities if they occurred.

The GPR results for suspect area 3 show a major ground disturbance in the southern part of the suspect area (Figure 4.15). Elevated surface radiation was also found in the area. The suspect area also has low soil mounds and shallow depressions. The match between the GPR disturbance area and elevated surface radiation suggests that radioactively contaminated waste might have been disposed of there.

In suspect area 4, the correlation of anomalous GPR results with elevated surface radiation is not as good as in suspect area 3 (Figure 4.15). It is not clear whether suspect area 4 was used as a disposal site for radioactive waste.

Although the GPR survey did not successfully identify any USTs in the south-central part of Site A (tank suspect area 1, Figure 1.3), a tank was identified by tracing a riser pipe. It is uncertain whether additional tanks are present there. According to an old map (Golchert and Sedlet 1977), a boiler house was located in the same general area. More than one underground fuel tank may have been used for the boiler.

The suspected UST area in the northeastern part of Site A (tank suspect area 2) was confirmed by anomalous GPR signals. The signals were clear, and locations of the tanks were tentatively identified (ORAU 1991). For tank suspect area 3, no GPR results were provided (ORAU 1991). It is assumed that no UST was found. It is unclear whether the preliminary identification of the tank's location was correct. Tank suspect area 3 may be either the same as tank suspect area 4 (see next paragraph) or a separate tank area in the Fire Station.

Besides the three tank areas described above, additional USTs may be present at the site. From some aerial photographs dated in the 1940s, a gasoline pump has been identified near the west entrance of the site (tank suspect area 4, Figure 1.3). About $20 \mathrm{ft}$ from the pump, several 55-gal drums were stored in open area. Because of the presence of the gasoline pump, it is reasonable to assume that one or more USTs may exist around the pump station. This area should be investigated further.

The GPR survey was made in early spring (April 30 through May 10, 1991). Soil moisture content would be expected to be high at that time. The moisture and the clayey till underneath the surveyed areas would limit the depth to which GPR signals could penetrate. Also, big trees, rubble, and the heterogeneous nature of the till may create some noise in the GPR results. Therefore, an additional geophysical survey, such as one conducted with a magnetometer, should be considered in the future to confirm the findings of the GPR survey for Site A. 


\section{ESTIMATED ROUTES OF CONTAMINANT TRANSPORT}

Because many data have been collected for Plot M, a more specific groundwater pathway model can be developed in addition to what has been provided in Section 3. This model is described in the next several subsections. A tentative surface pathway model for Site $\mathbf{A}$ is also proposed here.

\subsection{GROUNDWATER ROUTES FOR PLOT M}

Because Plot M is capped, waste in the plot is not exposed to surface weathering processes. Thus, the dominant process is the subsurface transport of contaminants as the contaminated soil under Plot $M$ interacts with groundwater in both the saturated and unsaturated zones. To understand the transport of contaminants under the site, it is useful to develop a conceptual model for groundwater movement. In the following subsections, the

pattern of contaminant distribution near Plot $M$ is examined, previous conceptual models are reviewed, and a modified model is suggested.

\subsubsection{Pattern of Contaminant Distribution}

Tritium is the most mobile element in groundwater, and we know that it was disposed of in Plot M. Because of its high mobility and because data are available from several investigations (Golchert and Sedlet 1977; Olimpio 1982, 1984; Nicholas and Healy 1988), tritium can be used as a conservative indicator for contaminant transport under Plot M.

\subsubsection{Tritium in Glacial Tills}

Olimpio (1984) and Nicholas and Healy (1988) have extensively examined the tritium data from the core samples near Plot $M$. In summary, the glacial drift underneath Plot $M$ is contaminated. Tritiated water has been found around Plot M, both in the groundwater of the perched aquifer (in Request 413, ORNL 1989) and in the soil moisture of the tills. The maximum concentration of tritium detected was greater than $100,000 \mathrm{nCi} / \mathrm{L}$, recorded in the early 1980s (ANL 1979, Nicholas and Healy 1988) at depths ranging from 30 to $70 \mathrm{ft}$ below Plot M (Figures 4.2 and 4.3).

The tritium-contaminated water has extended downward and northward (Olimpio 1984). In the downward direction, it has reached the bedrock dolomite aquifer. To the north, tritiated water has been found in area more than $200 \mathrm{ft}$ from the northern boundary of Plot M. Nicholas and Healy (1988) later added that the till underneath the Red Gate Woods Stream next to Plot $M$ was also contaminated with tritium to a depth of more than $20 \mathrm{ft}$. However, the contamination did not extend across the stream (Figure 5.1). 


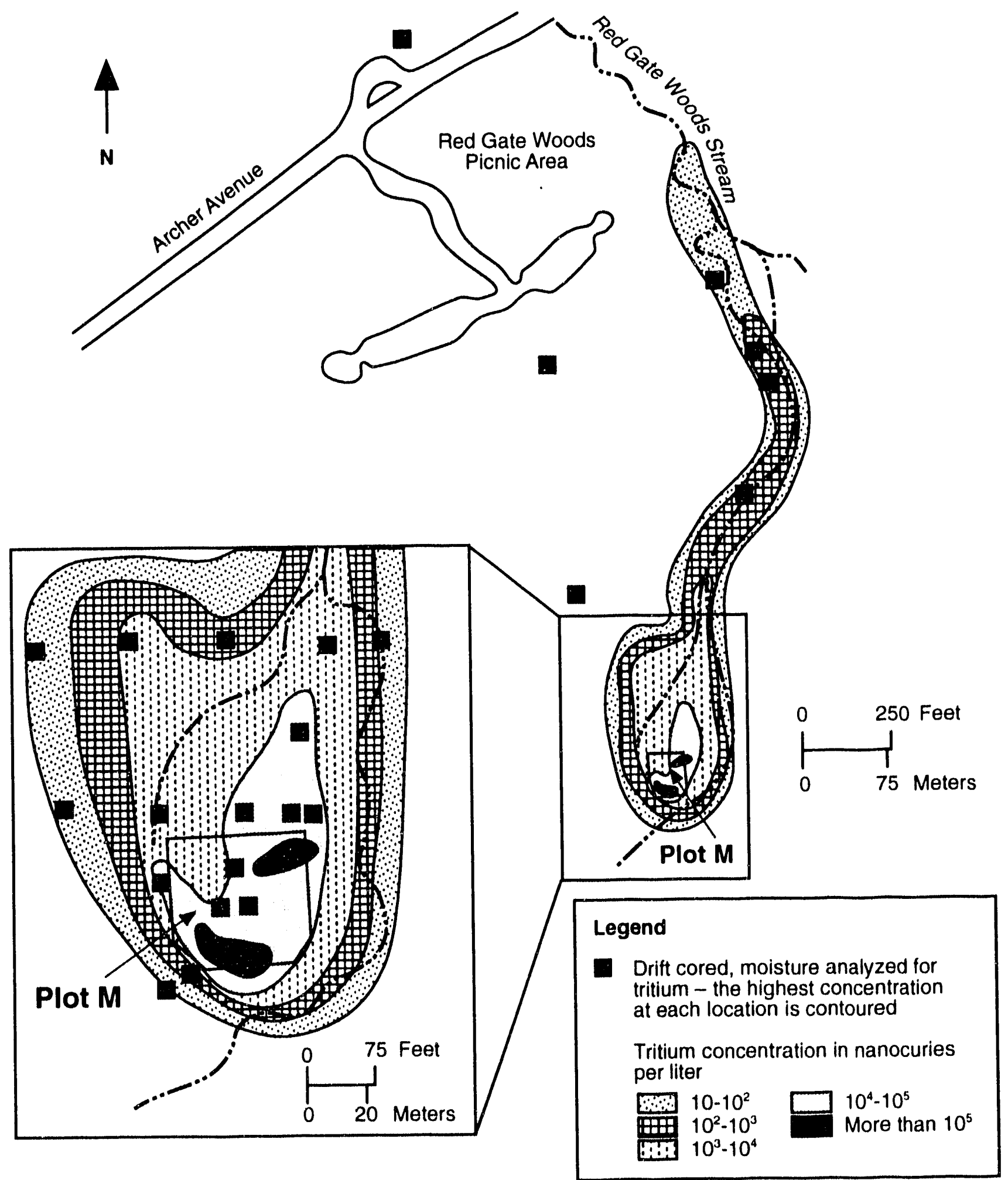

FIGURE 5.1 Extent of Tritium Plume in Glacial Tills under Red Gate Woods Stream (Source: Nicholas and Healy 1988) 


\subsubsection{Tritium in Dolomite Aquifer}

Because tritium was found in a well in the Red Gate Woods picnic area, the dolomite aquifer downgradient of Plot $M$ has been monitored intensively since 1973. Figure 4.9 shows the tritium concentration distribution for the dolomite aquifer in 1983. Two plumes have been delineated (Nicholas and Healy 1988). The northern plume centers around well DH-9 in the Red Gate Woods picnic area. Tritium levels near the bedrock/till interface range from 20 to $30 \mathrm{nCi} / \mathrm{L}$ (well $\mathrm{DH}-9$ ), while in bedrock, concentrations range from 4 to $10 \mathrm{nCi} / \mathrm{L}$ (well DH-11). The southern plume centers around Plot M. However, no data are available on the tritium level near the center. In comparison, the northern plume seems to have a greater areal extent than the southern plume. Between the two plumes, the tritium level in the bedrock groundwater is always below the detection limit. This pattern strongly suggests that the tritium traveled to the dolomite aquifer by two pathways.

\subsubsection{Previous Pathway Conceptual Models}

Plot $M$ seems to be the major tritium source for the surface water in the till and the dolomite aquifer. Olimpio (1984) proposes that the primary pathway for tritium migration is through vertical migration of leachate from Plot $M$. This theory accounts for the tritiated water found in the till and the bedrock aquifer directly beneath the plot. For the tritiated water in the upper part of the till and immediately north of the plot, the sand layers within the till provide an additional pathway. Olimpio (1984) assumes that no perched aquifer exists in the till and that tritium migration occurs primarily through flow in the saturated zone. The vertical migration rate for the contaminant is estimated to be $6.3 \times 10^{-6} \mathrm{~cm} / \mathrm{s}$, or $6.5 \mathrm{ft} / \mathrm{yr}$ (Olimpio 1984).

Nicholas and Healy (1988) modified Olimpio's model. They proposed an unsaturated zone underneath a perched aquifer in the till (Section 2.2.1.2). Both have been contaminated with tritium. The tritiated water in the perched aquifer is periodically diluted by seasonal recharging. Groundwater flows primarily through the sand layers toward the north-northeast (Nicholas and Healy 1988, Figure 11). In the unsaturated zone, tritiated water moves northward and downward. However, its downward movement has been stabilized, because the concrete cap on Plot $M$ reduced groundwater recharge into the tills (Nicholas and Healy 1988). The tritium concentration in moisture for the unsaturated zone remained nearly constant between 1977 and 1982 . The unconfined aquifer receives tritiated water from the unsaturated zone above it, which is then discharged downward to the bedrock aquifer.

According to Nicholas and Healy (1988), some tritiated groundwater from Plot M also discharges to the Red Gate Woods Stream at localized areas where the stream bottom intercepts sand lenses in the tills. Once in the stream water, the tritium travels downstream and enters the streambed (stream loss), contaminating the groundwater in the till underneath the streambed. The subsurface water then travels horizontally northward under the valley until it encounters a bedrock high (near well DH-9) near the Red Gate Woods picnic area and enters the bedrock aquifer. This pathway results in the northern plume in the bedrock aquifer. 


\subsubsection{Modified Pathway Conceptual Model}

The vertical pathway for tritium migration in the till has been confirmed by tritium data measured in soil moisture collected from soil cores under Plot M (Olimpio 1984; Golchert and Sedlet 1984b; Golchert et al. 1983). That pathway, therefore, will not be repeated in the following discussion.

The models provided by Olimpio (1984) and by Nicholas and Healy (1988) need to be modified because these models still do not explain all the data. First, Olimpio's model cannot explain the presence of the northern plume in the dolomite aquifer. Second, the tritiated water in the sand lens would not enter the Red Gate Woods Stream near Plot M if the dip of the sand lenses and the hydraulic gradient is toward the north, as claimed by both models. Third, the hypothesis that contaminated surface water is the source of the tritiated water under Red Gate Woods Stream (Nicholas and Healy 1988) is not substantiated by field observations. Because seepage occurs near the upper reach of the stream, the surface water is unlikely to enter the streambed. Table 5.1 summarizes the tritiated groundwater pathways reported by Olimpio (1984), Nicholas and Healy (1988), and this report. The table excludes the downward percolation pathway, which results in the plume underneath Plot $M$.

The model proposed here recognizes that the upper part of the glacial drift is a weathered zone. This zone is characterized by root openings, fissures, and sand lenses and layers in the drift. Because of the openings and fissures, precipitation may readily infiltrate in this zone. The number of fissures decreases with depth, and eventually the zone terminates at less permeable, unweathered drift.

T.' e weathered zone is $20-25 \mathrm{ft}$ thick. Its lower portion forms a perched aquifer, which is equivalent to the perched aquifer proposed by Nicholas and Healy (1988). The perched aquifer may be intersected by a few north-dipping sand lenses. The groundwater flow in the aquifer is primarily from the topographic high to the topographic low. If the groundwater flow intersects a sand layer in the drift, the groundwater in this perched aquifer may be diverted to flow along the sand layers. An artesian condition may occur where the sand layers are exposed in the hydraulic downgradient area.

Evidence that topography and sand layers are controlling factors in groundwater flow is provided by the seepage northeast of Plot $M$ (sampling location 6, Nicholas and Healy 1988, p. 19). The seepage occurs in a shallow sand layer in the weathered zone. Contaminants from Plot $M$, which is located on a topographic high, migrate through fissures in the weathered zone and sand layers, and emerge in the seep. Because the weathered zone also exists in the topographic high areas as well as underneath the Red Gate Woods Stream, tritiated water can travel below the surface from Plot $M$ to the stream valley. This results in the presence of tritiated water under the streambed (Nicholas and Healy 1988). Because a favorable hydraulic gradient is lacking, the plume does not migrate across the stream.

The northward migration of the plume under the Red Gate Woods Stream is assisted by the presence of the sand layers in the drift. The sand layers dip gently to the northnorthwest and provide a subsurface pathway for the groundwater in the perched aquifer. At 


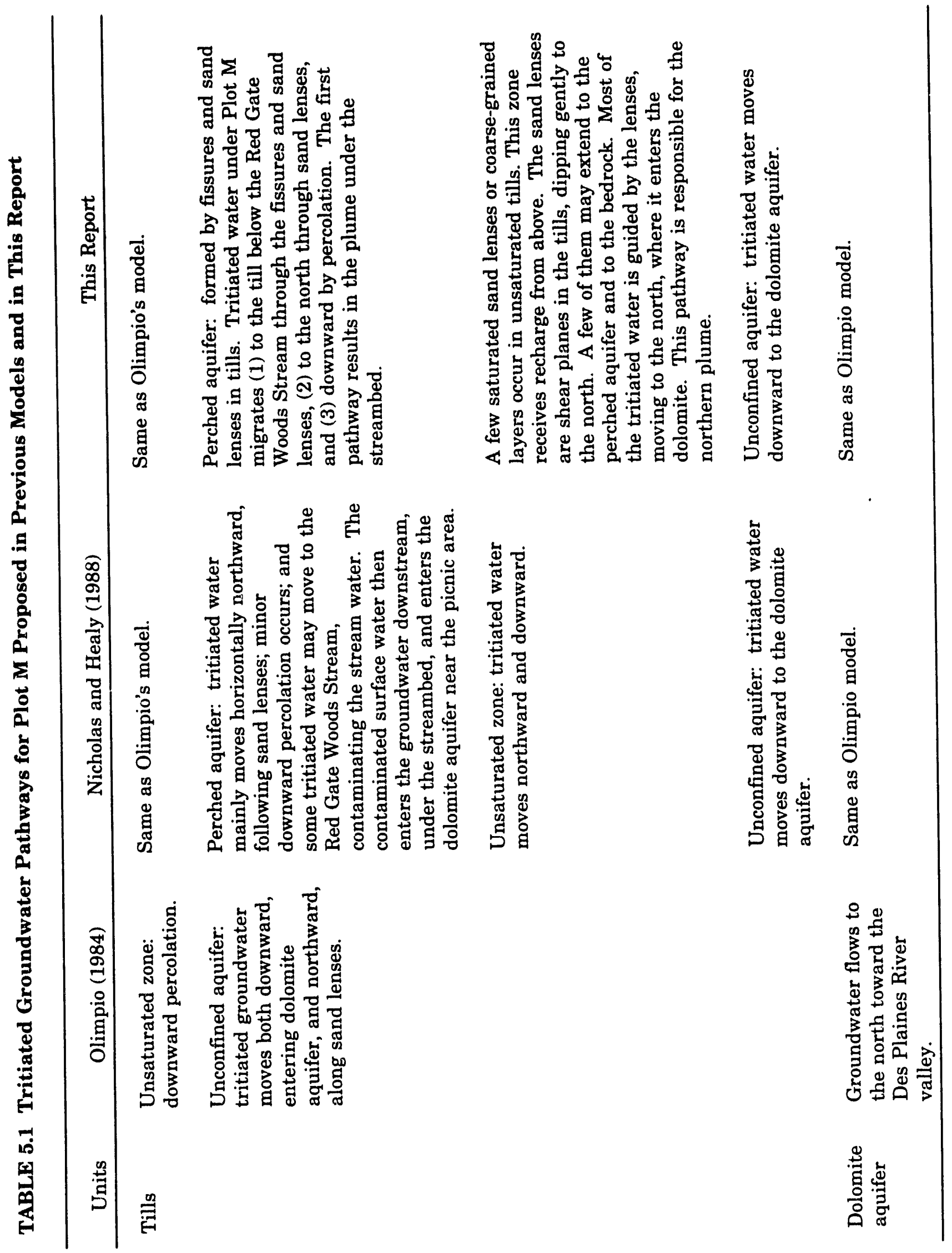


a depth below the weathered zone, the groundwater flow in the unsaturated zone is estimated to be parallel to the dip of the sand layers, to the north-northwest. This conclusion is consistent with the data on water levels (recorded in boreholes 1-6, 8, and 11), which show a hydraulic gradient toward the northwest (Figure 5.2). The favorable hydraulic gradient and the sand layers result in a tritium plume extending north-northwest in the valley.

Because a few north-dipping sand layers extend to the north or the northwest, they are likely to intersect the coarse material in the Wadsworth Till or the dolomite bedrock in the north (see Section 2.2). In the field, a few water-saturated sand layers have been reported in the unsaturated zone (ORNL 1989). It is likely that tritium would follow these sand layers and enter the dolomite aquifer, forming the northern plume in the bedrock aquifer. The entrance area for this plume is probably in the southern part of the picnic area.

The southern tritium plume underneath Plot $M$ is caused by vertical infiltration as modified by preferred migration along the sand layers. This pathway was elaborated by Olimpio (1984) and later modified by Nicholas and Healy (1988) (see Section 5.1.2).

The presence of tritium vapor in the Red Gate Woods valley next to Plot $M$ can be attributed to evapotranspiration of tritium-contaminated water trapped in the weathered zone. During the wet season, the infiltration of surface water in the streambed is limited because of the low storage coefficient of the fissures in the weathered drift. The surface water that does infiltrate probably mixes with the tritium-contaminated pore water near the surface in the valley before being released to the air through evapotranspiration.

\subsection{TRANSPORT ROUTES FOR SITE A}

Nearly all the radioactivity data for Site A came from surface surveillance. Well DH-1 provides the only subsurface data. Therefore, a comprehensive evaluation of contaminant migration for the site is impossible. However, with the surface data, a surface transport model can be developed. The model is elaborated here because many potential contaminant sources at Site A (e.g., the drain field, former building sites, and suspect areas 3 and 4) are near the surface. This model should be complemented with a subsurface transport model when additional data become available.

\subsubsection{Patterns of Areas of Elevated Radiation in Radiological Surveys}

The 1976 surface soil sampling survey (see Section 4) indicates that most of the areas with relatively low concentrations of cesium and tritium fall in a belt that extends from the Fire Station to the Well House at Site A. The areas showing higher levels of contamination are located south and southeast of the Well House. The latter tendency was further confirmed in the 1990 radiological survey. In addition, elevated readings were also found at scattered locations, such as near the Quonsets and the Storage Huts in the northern part 


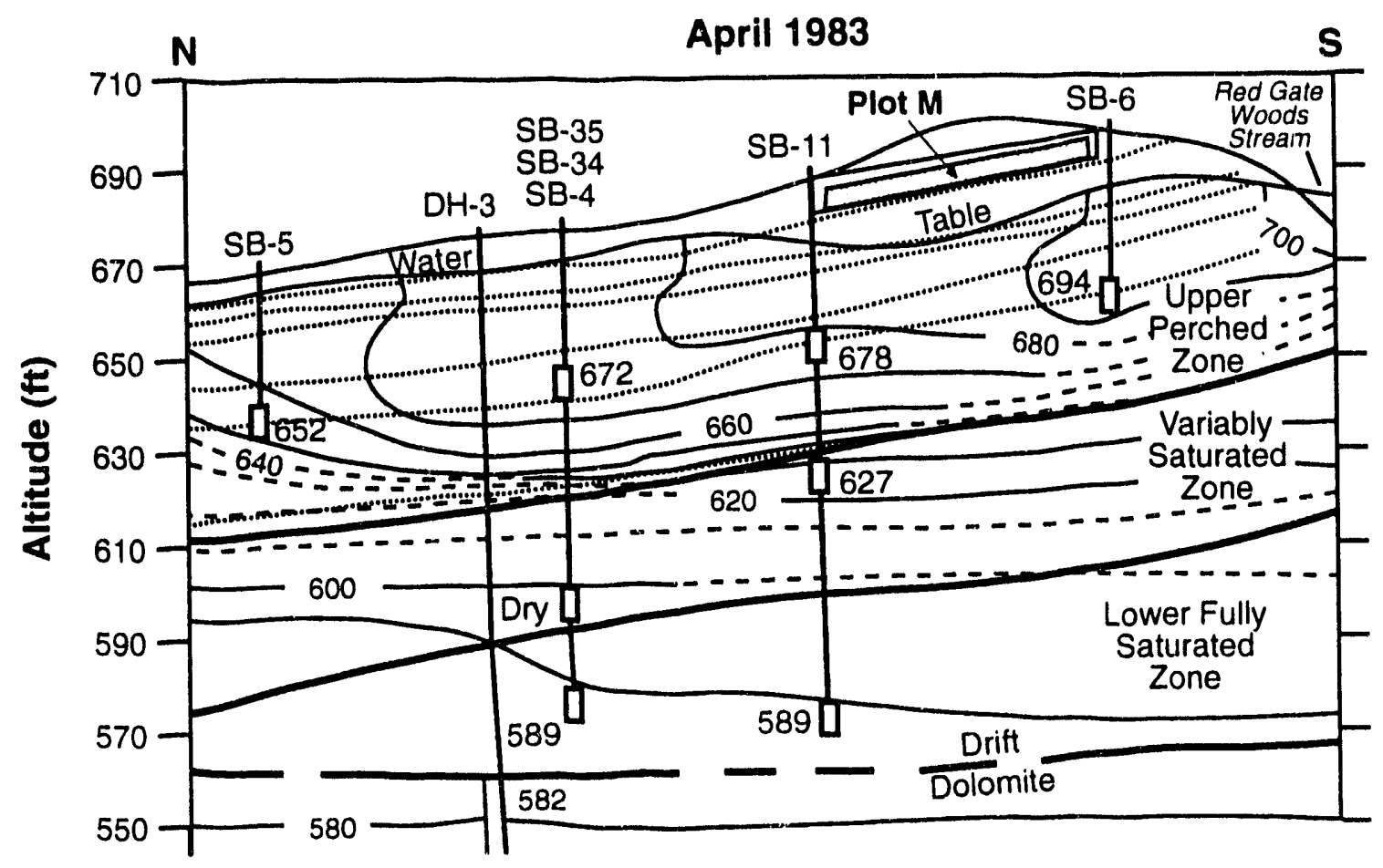

FIGURE 5.2 Groundwater Potential Contours for the Perched Aquifer near Plot $M$ in April 1983 (Source: Nicholas and Healy 1988)

of Site A, in the 1976 and 1990 surveys. Most of the areas of isolated elevated radiation in suspect area 3 are clustered in its southern part, while the areas of isolated elevated radiation in suspect area 4 are clustered in the south and east.

\subsubsection{Potential Surface Contaminant Sources at Site A}

Most of the above distribution pattern may be explained by past waste management practices. For example, the Fire Station, which was a garage, was used to store scrap and abandoned equipment. A radioactivity survey made in 1946 showed gamma readings of $10 \mathrm{mR} / \mathrm{h}$ at $2 \mathrm{in}$. over caves at the garage (DOE 1990). Caves are mentioned in DOE (1990), but no other evidence exists to verify their existence. The anomalies near Laboratories $B$ and $\mathrm{H}$ may be related to the temporary storage of scrap material in the past. According to DOE (1990), trash and scrap reportedly were piled behind Building $\mathrm{H}$ and Laboratory $\mathrm{B}$ (on July 21,1945 , and July 2, 1947) before they were hauled away and buried later. These scrap material and trash storage sites could be the sources of the contaminated discrete objects found at Site A. The areas of elevated radiation located in the drain field (in the eastern part of the site; Figure 4.11) may be related to radioactive material that was reportedly discharged into drains of the facilities (Young 1948).

A $30-\mathrm{ft}$ pit for the disposal of contaminated material was reported near the southeastern corner of the site (DOE 1990). Two suspect areas, which match the description of the location, have been tentatively identified at Site A (Figure 4.11). One area is located near the southeastern corner of the site and west of the drainage (suspect area 6, Figure 1.3). 
This area is suspected because its location fits the description of the disposal pit and its surface shows disturbance in aerial photographs. The second area is located immediately southeast of the Well House (suspect area 5, Figure 1.3). It is suspected because it shows elerated radioactivity (in surface soil and gamma scans), subsurface disturbance (as indicated in the GPR survey), and heavy traffic marks (shown in old aerial photographs).

The history of some areas of elevated radioactivity identified in the 1976 survey is less certain. For example, the area between Laboratory A and the Fire Station showed elevated activity in the 1976 survey, but not in the 1990 survey. A search of the records showed that the area reportedly had a reading of $25 \mathrm{mR} / \mathrm{h}$ on April 5, 1945 (DOE 1990). The reason for such activity is not known. Similarly, the reason is not understood for the elevated readings shown at three locations near the Quonsets and at one location near the Storage Huts (Figure 4.11) in the 1976 survey.

Several old photographs show two air emission stacks. The one by the Boiler House is $50 \mathrm{ft}$ tall, and a shorter one is adjacent to Laboratory A. The shorter stack was probably used specifically for the laboratory. As radioactive material was used in experiments, it might have been dispersed through the stack. These emissions might result in higher levels of radionuclides around the stack than in other areas. The stack next to the Boiler House probably had no effect on the radionuclide levels at Site A.

Drains are another potential source of radioactive contamination at Site A. Surface water samples collected in 1990 and 1991 at the confluence of the tiles in the northeastern part of Site A show consistently slightly higher levels of tritium and potassium-40 than do other surface water samples in the area (Allen 1992). This contamination might be related to the past disposal of radioactive contaminants through sinks and drains at the site (DOE 1990).

\subsubsection{Potential Surface Contaminant Sources at Suspect Areas 3 and 4}

An examination of old aerial photographs dated in the 1940s and 1950s showed that most activities were limited to the southern part of suspect area 3 and the eastern and southern parts of suspect area 4.

The radioactivity survey also showed elevated readings in the southern part of suspect area 3 (Figure 4.15). The GPR investigation (ORAU 1991) reveals thit the radioactively anomalous area coincides with a major disturbed area. The disturbed area can be as deep as $10 \mathrm{ft}$. Unfortunately, the subsurface soil of the disturbed area was not sampled. The shallow borehole samples taken in the Phase 1 study were outside the disturbed area. The U-235, U-238, and Cs-137 concentrations in the collected samples were not significantly different from the levels in the local soil.

Similar consistency occurs for suspect area 4. Most activities centered on the eastern and southern parts of the area, as indicated in the aerial photographs. The same general areas also show major soil disturbance in the GPR survey (Figure 4.15). Unfortunately, all 
the soil boring samples collected later in the Phase 1 study fall outside the radioactively anomalous zone. Thus, U-235, U-238, and Cs-137 concentrations in the samples were not significantly different from those in local soil.

\subsubsection{Surface Pathway Model}

On the basis of currently available data, most of the surface-contaminated and suspect areas at Site A are closely related to local sources. Widespread lateral dispersion is unlikely, perhaps because of the flat topography of the site and its vegetation cover.

Two recent discoveries - the low levels of acetone and ketone in a dolomite well (DH-1) at Site A and the extraordinarily high levels of tritium in surface-water samples taken near the Archer Avenue entrance - are confusing. These new data may indicate that a subsurface transport pathway may be important, although the exact migration route is unknown. 


\section{EVALUATION OF PHASE 2 WORK PLAN FOR SITE A}

The Phase 2 Work Plan describes the need for further investigation in the following areas: Site A, suspect areas 3 and 4, the drain field, three USTs, and the Old Lead Foundry area. The following review of this work plan is based on the premise that additional investigation may be required if the results from the Phase 2 investigation warrant additional characterization. For clarity, each investigative task outlined in the Phase 2 Work Plan is printed in italics, with ANL's evaluation immediately below it.

\subsection{PREVIOUSLY IDENTIFIED AREAS OF CONCERN}

Conduct electromagnetic scans of cleared areas on Site A and Suspect Areas 3 and 4 to delineate extent (areal and depth) of foreign objects and materials.

This task has been completed: a GPR survey was conducted in these areas. In addition, a magnetometric survey should also be done on the same grid, to complement the GPR. Like a GPR survey, a magnetometric survey detects foreign objects and materials, but, unlike GPR, it can distinguish between metallic and nonmetallic buried objects. This survey could also locate buried drain lines that run throughout Site A.

Conduct soil sampling at Site A and Suspect Areas 3 and 4 as follows:

- 2-foot intervals to original soil depth in debris and waste material (at 6-8 locations per site); specific locations will be determined as a result of electromagnetic scans.

Soil samples should be taken at 1-ft intervals, rather than 2-ft intervals, because the debris and waste is not believed to be very deep. To determine if contaminants are migrating, each sample should be taken to at least $1 \mathrm{ft}$ beyond the original soil depth.

- 4-foot intervals to shallow water table on perimeter (at 6-8 locations per site); specific locations to be based on findings of EM scans.

Soil samples should be taken at 2.5-ft intervals, and, if necessary, additional samples should be collected from the soil borings at depths where the soil is obviously contaminated. The shorter sampling intervals will help characterize the area more fully and reduce the chances of needing to return to the boring location to collect additional data. These samples will help determine if contaminants are migrating through the soil column.

'?erform further investigations (shallow hand digging and direct monitoring) in an attempt to identify any additional discrete radiation sources from locations identified during the Phase 1 survey. 
Given the recent discovery of graphite bricks with slightly elevated levels of radioactivity, this survey should be done with a smaller grid interval than the one used in the Phase 1 survey, and it should extend to all foreign objects that are found at the surface. Also, a subsurface gamma ray survey should be performed at depths of 2 and $4 \mathrm{ft}$.

Collect samples of standing water from areas of investigation on Site A and Suspect Areas 3 and 4.

This task is highly recommended; however, sediment in these areas should also be sampled. Sampling both surface water and sediment will help determine whether contamination is being transported off site by runoff.

\subsection{SITE A DRAIN FIELD}

Conduct soil sampling at 4-foot intervals to shallow water table at 6 representative locations in the septic drain field.

Soil samples should be taken at 2.5 - $\mathrm{ft}$ intervals to the water table or $10 \mathrm{ft}$ below the land surface, whichever occurs first. The shorter sampling intervals will help characterize the area more fully and may eliminate the need to return to the boring location to collect additional data. Additional samples should be collected from the soil borings at depths where the soil is obviously contaminated. This procedure will help determine whether contaminants are migrating through the soil column.

\subsection{FORMER UNDERGROUND STORAGE TANKS}

Monitor sites with electromagnetic detectors to determine location of tanks (if still present).

A magnetometric or electromagnetic survey should be redone to locate the USTs. A survey should also be done in the area where the old gasoline pump was located.

Conduct monitoring at tanks vents to assure that flammable/explosive gas conditions do not exist.

This task is highly recommended, because it will help to determine whether the tanks still contain an product. If a product is found, a sample should be taken and analyzed. The tanks should be properly abandoned according to Illinois regulations on USTs.

Sample soil at 4-foot intervals to shallow water table at 2 locations near each tank.

Soil samples should be taken at 2.5 - $\mathrm{ft}$ intervals to the water table or to $20 \mathrm{ft}$, whichever occurs first. The shorter sampling intervals will help characterize the soils more fully and may eliminate the need to return to the boring location to collect additional data. 
If needed, additional samples should be collected from the soil borings at depths where the soil is obviously contaminated. This procedure will help determine if contaminants are migrating through the soil column.

\subsection{FORMER LEAD FOUNDRY AREA}

Collect soil samples at 4-foot intervals to depth of approximately 12 feet at 2 locations.

Because the exact location of the foundry is not known, a grid of at least 10 borings should be developed over the area. Soil samples should be taken at 2.5 -ft intervals to at least $4 \mathrm{ft}$ past the original soil depth. If needed, additional samples should be collected from the soil borings at depths where the soil is obviously contaminated. This procedure will help determine if contaminants are migrating through the soil column.

\subsection{OTHER AREAS}

Collect additional samples and measurements to further delineate extent of contamination in any areas where Phase 1 surveys or findings during activities described above may suggest residual activity.

This task is highly recommended, because it will help to further determine the extent and magnitude of contamination and may provide some information on transport of contaminants. However, on the basis of the results of the Phase 1 survey, some of the contaminated areas have now been identified.

\subsection{SAMPLE ANALYSES}

All soil samples will be analyzed for radiological constituents by gamma spectrometry. Individual samples from locations identified by surface scans and selected samples from suspect areas will be analyzed for strontium-90, plutonium, and tritium. Other samples will be composited in groupings of five to ten for analyses for these radionuclides, and if composite samples indicate possible residual contamination, analyses of individual components will be performed. Water samples will be analyzed for tritium and gross alpha/gross beta activity. Additional isotopic analyses will be performed if levels exceed $15 \mathrm{pCi} / L$ gross alpha or $50 \mathrm{pCi} / \mathrm{L}$ gross bsta.

A gross beta and gross gamma activity survey should be done first; then, any samples that have elevated levels should be analyzed by means of gamma spectroscopy.

Approximately $25 \%$ of the samples from the areas of further investigation on Site $A$ and Suspect Areas 3 and 4 and from the Septic Drain Field will be analyzed for EPA Target Compound List (TCL) volatile and semivolatile 
organics and metals. Approximately six samples from the Suspect Areas 3 and 4 will also be analyzed by the Toxicity Characteristics Leaching Procedure (TCLP). All samples from the sites of the former underground storage tanks will be analyzed for TCL organics and all samples from the former lead foundry area will be analyzed for TCL metals.

This sample analysis protocol is adequate for the initial phase of the investigation.

\subsection{GENERAL RECOMMENDATIONS}

On the basis of the findings of the Phase 2 investigation, the need for any additional investigation should be determined. The decision on the types and locations of additional samples should be based on conclusions resulting from the Phase 2 investigation.

It is highly recommended that duplicate soil samples be collected during each sampling event. One duplicate sample should be collected for every 20 (or fewer) regular soil samples collected from each area under investigation. An equipment blank should also be collected during sampling from each area to ensure that the equipment has been properly decontaminated.

Groundwater samples should also be collected from all wells that will be installed at Site $\mathrm{A}$ under a separate task that is not reviewed in this document. These wells should be sampled by using a stainless steel bailer pulled by a stainless steel or nylon rope. A trip blank, an equipment blank, and one duplicate sample should be collected, in addition to the actual sample. To prevent cross-contamination of the monitoring wells and the groundwater samples, the sampling equipment should be decontaminated before sampling begins and after each well is sampled.

Groundwater samples from all wells should be analyzed quarterly for TCL constituents (metals, VOCs, SVOCs, and PCBs/pesticides), because one rcund of sampling will not provide enough data to determine the quality of the groundwater. These analyses will help to determine the extent and magnitude of the acetone and methyl ethyl ketone contamination found in well DH-1 and may provide some information on contaminant transport.

In addition, the existing sampling protocol should be evaluated. The objective of most groundwater-quality monitoring programs is to obtain samples that are representative of existing groundwater conditions or samples that retain the physical and chemical properties of the groundwater within the aquifer. Factors that affect the success of such programs are the design, installation, and development of the monjt ing wells, as well as human influences such as collection, handling, preservation, and analysis of the samples. Currently, the only sampling protocol used at Site A/Plot M is Sampling Subsurface Water From Plot M Boreholes, SCP-020 (December 1990), developed by the ANL Environment and Waste Management Program. This sampling protocol was developed to sample groundwater for tritium analysis. However, it is not adequate for sampling the various media for TCL 
constituents. To ensure the collection of representative samples, a comprehensive, sitespecific soil and groundwater sampling and analysis program needs to be developed and implemented. 


\section{PRELIMINARY IDENTIFICATION OF APPLICABLE OR RELEVANT AND APPROPRIATE REQUIREMENTS AND TO-BE-CONSIDERED CRITERIA}

Under the National Oil and Hazardous Substances Pollution Contingency Plan (NCP) (40 Code of Federal Regulations [CFR] 300), remedial actions must meet all federal and state applicable or relevant and appropriate requirements (ARARs). Section 300.430(b) of the NCP requires that the identification of ARARs and other "to-be-considered" (TBC) criteria be initiated during the scoping phase of the remedial investigation/feasibility study (RI/FS). This identification process is started during the scoping phase so that the results can be used in the development of preliminary remedial action objectives, goals, and alternatives.

ARARs consist of promulgated standards (e.g., public laws codified at the state or federal level) that may apply to a proposed action or that may be relevant and appropriate to all or part of that action. TBC requirements consist of standards or guidelines that have been published but not promulgated and that may have significance for all or part of the action. (DOE orders are not promulgated standards and are therefore treated as TBC requirements, even though such orders are applicable to all DOE actions.) Typically, potential TBC requirements are considered only if no promulgated requirements exist that are either applicable or relevant and appropriate or if ARARs alone would not be sufficiently protective.

Guidance from the EPA defines applicability as implying that the proposed action or site circumstances satisfy all of the jurisdictional prerequisites of the requirement. Relevant and appropriate requirements are defined as those that address problems or situations sufficiently similar to those encountered at the site in question that their use is well suited to the particular site. Any standard, requirement, criterion, or limitation under any federal or state law may be considered either applicable or relevant and appropriate to a specific action. Promulgated state requirements become ARARs if they are (1) legally enforceable and generally applicable (i.e., consistently applied) and (2) more stringent than federal laws. A determination of applicability is made for the requirements as a whole; a determination of relevance and appropriateness may be made for only specific parts of the requirements.

ARARs are divided into three categories: (1) contaminant-specific ARARs address certain contaminants or a class of contaminants, and they relate to the level of contamination allowed for a specific pollutant in various environmental media (e.g., soil, water, and air); (2) location-specific ARARs are based on the specific setting and nature of the site; and (3) action-syecinic ARARs are related to specific technology or activity-based requirements for response actions proposed for implementation at the site.

The preliminary identification of potential ARARs for the proposed remedial action at Plot $\mathrm{M}$ is based on the location of Plot $\mathrm{M}$, the nature of the contamination, and the possible response actions. ARARs should be modified, as necessary, as more information becomes available. Preliminary determinations of whether ARARs or TBCs are applicable (or 
potentially applicable) or relevant and appropriate (or potentially relevant and appropriate) are presented in Appendix B. The preliminary requirements listed in Appendix B are abstracts from statutes and regulations. Before ARARs are determined and a remedial action is chosen, the full text of the applicable statutes and regulations must be consulted to ascertain if there are specific exclusions or special applications to actions, locations, or contaminants outside these general requirements. Under the NCP (40 CFR 300.43), other lead and support agencies may also identify other pertinent advisories, criteria, or guidance. Appendix B includes potential ARARs from all sources and does not eliminate standards that are less restrictive or chose among ARARs from different sources (i.e., the U.S. Nuclear Regulatory Commission, DOE, EPA, or state agencies). In addition, for cases in which multiple contaminants or multiple pathways of exposure are revealed, negotiation may be necessary to adjust the limits accordingly. Final ARARs must be determined in consultation with DOE's counsel and in conjunction with the appropriate regulatory agencies when the remedy is selected. 


\section{RECOMMENDATIONS}

The following recommendations are presented in two parts. The first part outlines a strategy that may help streamline the investigation of Site A and Plot M. The second part discusses the specific actions that should be taken for different potential release sites.

\subsection{INVESTIGATION STRATEGY}

An investigation strategy helps a project manager make correct decisions during the course of site investigations and during the design and implementation of remedial actions. The strategy helps the manager identify important problems early and assign priorities to all potential release sites. The result is a more focused and more efficient investigation. Therefore, response actions can be implemented in a timely fashion.

\subsubsection{Identify Specific ARARs}

ANL has identified all federal and state ARARs for the known contaminants and media at Site A/Plot M (Section 7 and Appendix B). However, additional ARARs that are specific to Site A/Plot M may need to be defined. These specific ARARs will help focus subsequent data gathering efforts and will help develop remedial alternatives, including a no-action alternative.

\subsubsection{Assign Priorities for Investigations}

Different areas of Site A and Plot M may pose different levels of potential threat to human health and the environment. High priority should be placed on the areas that may have high potential for contaminants to reach human receptors. Because the quantity and quality of data are not equal across areas, the determination of priorities must be based on professional judgments as well as results. As additional information is collected during the investigation, the priority order may change.

Table 8.1 lists areas of concern at Site A/Plot M. They are arranged by the severity of their potential impacts on humans. Within a group, no difference in priority is indicated by order. The criteria used to assign priority include accessibility of the contaminants, severity of contamination, and types of contaminated media (e.g., surface water, groundwater, or soil). Within the table, the objective of the next phase of the investigation, if needed, is also suggested. 
TABLE 8.1 Relative Priorities for Various Sites on Site A and Plot $\mathbf{M}^{\mathrm{a}}$

Study Areas

\section{High Priority for Study}

Suspect areas 3 and 4

Probably waste disposal areas. Discrete radioactive objects found. Areas of isolated elevated radiation found. Accessible to public.

Area around Laboratories A, B, and $\mathrm{H}$

Possible waste pit and disposal area near the southeastern part of Site A

Seepage near Plot $M$

Stream northwest of Site A
Possibly temporary storage areas for scrap and waste were located outside buildings. Discrete radioactive objects found. Areas of isolated elevated radiation found. Accessible to public.

Possible waste disposal site. Accessible to public.

Radioactive contamination in soil under the plot has been confirmed.

Contaminants have migrated to surface through seepage. Accessible to public.

Tritium found in surface water at the entrance to Site A. Accessible to public.

Objectives for Next

Phase of Study

Delineate the extent of source areas, characterize the source, and outline remedial alternatives.

Identify and delineate the source of contaminants and the extent of contamination; outline remedial alternatives.

Identify the location of the pit and the nature of contaminants in the source; outline remedial alternatives.

Characterize the contaminant migration pathway through sand layers.

Identify the source of contamination.

\section{Moderate Priority for Study}

Plot M

Picnic area

Buried reactor shields
Radioactive contamination in soil under the plot has been confirmed.

Low levels of tritium found in water supply wells. Accessible to public.

Acetone and ketone found in groundwater near the reactor burial site. The fill material in the burial site is permeable and could create a secondary contaminant source if contamination occurs at Site A subsurface.
Characterize the migration pathway of contaminants in the middle and lower parts of the tills.

Monitor the level of contaminants in supply well.

Identify the source of acetone and ketone and determine any groundwater contamination near the bottom of the fill. 
TABLE 8.1 Relative Priorities for Various Sites on Site A and Plot M (Cont.)

\begin{tabular}{|c|c|c|}
\hline Study Area & Comment & $\begin{array}{l}\text { Objective for Next } \\
\text { Phase of Study }\end{array}$ \\
\hline \multicolumn{3}{|l|}{ Low Priority for Study } \\
\hline $\begin{array}{l}\text { Underground storage } \\
\text { tanks }\end{array}$ & $\begin{array}{l}\text { VOCs found in soil gas samples in the } \\
\text { northeast near a tank area. Two potential } \\
\text { tank areas have been identified. }\end{array}$ & $\begin{array}{l}\text { Delineate the two potential tank } \\
\text { areas, characterize the contents } \\
\text { of all tanks on site, and list } \\
\text { remedial alternatives. }\end{array}$ \\
\hline Drain tield & $\begin{array}{l}\text { Very low level of radioactive contamination } \\
\text { found near the land surface. Accessible to } \\
\text { public. }\end{array}$ & $\begin{array}{l}\text { Determine the nature of } \\
\text { nonradioactive contaminants and } \\
\text { the vertical extent of } \\
\text { contamination. }\end{array}$ \\
\hline $\begin{array}{l}\text { Drain system } \\
\text { and outfall on Site A }\end{array}$ & $\begin{array}{l}\text { Low level of radioactive contamination } \\
\text { near the outfall of the drain. Waste } \\
\text { disposed of through drains in the past. } \\
\text { Outfall accessible to public. }\end{array}$ & $\begin{array}{l}\text { Monitor the outfall for } \\
\text { contaminants; determine the } \\
\text { vertical extent of contamination } \\
\text { near the outfall, if present; and } \\
\text { delineate the drain system. }\end{array}$ \\
\hline \multicolumn{3}{|c|}{ Very Low Priority for Study } \\
\hline Former building sites & $\begin{array}{l}\text { Lead Foundry, garages, laboratories, open } \\
\text { area between Laboratory A and Fire } \\
\text { Station, and storage buildings might have } \\
\text { been contaminated and might not have } \\
\text { been completely decontaminated. } \\
\text { Accessible to public. }\end{array}$ & $\begin{array}{l}\text { Determine whether any residual } \\
\text { radioactive and nonradioactive } \\
\text { contamination exists on previous } \\
\text { building sites. }\end{array}$ \\
\hline $\begin{array}{l}\text { Surface water bodies } \\
\text { around Site } A\end{array}$ & $\begin{array}{l}\text { No significant contamination has been } \\
\text { found in the surface water bodies near } \\
\text { Site A. Accessible to public. }\end{array}$ & $\begin{array}{l}\text { Monitor any off-site migration of } \\
\text { contaminants, if present, and } \\
\text { confirm no nonradioactive } \\
\text { contamination. }\end{array}$ \\
\hline $\begin{array}{l}\text { Suspect areas } 1 \\
\text { and } 2 .\end{array}$ & $\begin{array}{l}\text { No radioactive contamination found in a } \\
\text { radioactivity survey. Accessible to public. }\end{array}$ & $\begin{array}{l}\text { Confirm no nonradioactive } \\
\text { contamination. }\end{array}$ \\
\hline
\end{tabular}

a Within a group, order does not indicate any difference in priority. 


\subsection{RECOMMENDED SITE-SPECIFIC ACTIONS}

This report is based on data of varying quality and completeness. The variability is the result of several gaps in the ongoing environmental monitoring program: it relies on data obtained from a well network at Plot $M$ that was not properly designed (by today's standards [EPA 1991]) to detect migrating contaminants; past analyses have not included the TCL (EPA 1987); the groundwater and soil geochemistry have not been characterized to help determine soil/water/contaminant interactions (Drever 1988; Longmuir and Mahoney 1984); and the hydrogeologic flow system at Site $\mathrm{A}$ has not been characterized. The following actions are recommended to help characterize both Plot $M$ and Site $A$. The recommendations for Site $\mathrm{A}$ are in addition to those made in Section 6 regarding the Phase 2 Work Plan.

\subsubsection{Plot $\mathbf{M}$}

\subsubsection{Monitoring Well Network}

The glacial drift monitoring wells at Plot $M$ were constructed with well screens made of perforated and vertically slotted polyvinyl chloride (PVC) pipe. This type of well screen has several problems: screen openings cannot be closely spaced; the percentage of open area is low, preventing rapid recovery after purging; the opening sizes are highly variable, so the holes are not consistent with the natural formation material; and the opening sizes are never small enough to keep fine materials from entering the well. Well screens of this type will either become clogged, so groundwater cannot enter the well, or they will allow clay, silt, and sand to enter a well, making it impossible to collect silt-free samples (EPA 1991). On the basis of the approximate dates of installation (1976 to 1977), it is also probable that the PVC wells were constructed with PVC glue at all pipe joints. Because the PVC glue is not stable, it will leach out of the joints and may interfere with sample analysis (Sosebee et al. 1983, EPA 1991).

The middle section ( 40 to $80 \mathrm{ft}$ ) of the till near Plot $\mathrm{M}$ was the center of the tritium plume in the early 1980s. How ver, most of the monitoring wells installed are either screened in the upper (11 wells) or the lower ( 4 wells) part of the till. To characterize the movement of the plume, additional wells screened in the middle and the lower sections of the till are needed. These wells would help define the migration pathway and the extent and magnitude of the contamination.

The dolomite bedrock wells, built in 1976, were not designed to properly monitor the groundwater for contaminants (EPA 1991). They were constructed out of black steel casing, which, in the presence of aggressive aqueous solutions, could leach or adsorb chemical and radionuclide constituents to and from the casing material. The steel casing extends to just belcw the top of the bedrock surface, leaving the remainder of the well annulus open. The length of the open well annulus (well intake) is $40 \mathrm{ft}$ for DH-1, $41 \mathrm{ft}$ for DH-2, $45 \mathrm{ft}$ for DH-3, and $165 \mathrm{ft}$ for DH-4 (Olimpio 1982). Well construction data are not available for the remaining bedrock wells. 
In general, monitoring well intakes are typically 2 to $10 \mathrm{ft}$ long and only rarely equal or exceed $20 \mathrm{ft}$. Shorter intakes provide more specific information about vertically distributed water quality (EPA 1991). Long well intakes, such as those on the dolomite wells, dilute the groundwater samples and thus do not provide an accurate picture of the magnitude of contamination or the discrete zone of contamination. Shorter well screens and filter packs are highly recommended for the bedrock wells. They would prevent particulate matter that is carried through the fractures and solution channels from interfering with the groundwater samples.

Four dolomite wells, DH-6, DH-7, DH-8, and DH-9, have collapsed, but they are still sampled on a quarterly basis. Because they have collapsed, it is impossible to determine the source of the water in these wells. Thus, it is difficult to compare the analytical results from these wells with those from other wells in the network. Well DH-13 has been vandalized and is no longer useful. These wells should be properly abandoned and replaced with properly constructed monitoring wells.

Given current technology, it appears that the wells in the existing monitoring well network, in both the glacial till and bedrock, are not properly constructed or located to detect contaminants migrating from Plot M. The glacial till wells, because of their construction (the use of perforated well screens), may not even provide accurate water level readings (EPA 1991). New, properly constructed monitoring wells should be installed in both up- and downgradient locations. The new wells should be installed in both the glacial till and the dolomite bedrock. A detailed analysis should be performed to determine if it would be prudent to continue to monitor existing wells after new wells are installed, so that, if possible, data collected previously can be correlated with data from the new wells.

All existing wells should be properly abandoned according to Title 77 of the Illinois Administrative Code. The code states:

The owner of a water well, boring or monitoring well shall assure that such well is sealed within thirty (30) days after it is abandoned and no longer used for the purpose for which it was intended. Wells shall be sealed by a licensed water well driller. Wells which are abandoned shall be sealed by placing the sealing materials from the bottom of the well to the surface by methods that will avoid segregation or dilution of materiai. Extensions of the 30 days may be obtained if the Department of Health is assured that applicable measures will be taken. Applicable protective measures may include ensuring sources of contamination are downgradient from the water source or isolation of the potential source of contamination in such a manner as to prevent a route of contamination of the ground water or isolating the potential source of contamination to prevent accidental introduction of contaminants into the groundwater.

The EPA (1991) has detailed procedures for well abandonment, which are included in Appendix $\mathrm{C}$ of this report. 


\subsubsection{Soil Boring Samples}

Additional soil boring samples should be collected from under and around Plot M. and analyzed for TCL constituents. These results would help evaluate the nature and extent of nonradioactive contamination under and around Plot $\mathrm{M}$.

During the installation of the new monitoring wells at Plot M, soil samples should be collected and analyzed for TCL constituents. Depending on the results of these analyses, additional borings may be required to determine the extent and magnitude of contamination in the soils surrounding Plot M.

\subsubsection{Groundwater Sampling and Analysis Program}

The sampling and analysis program needs to address a much broader range of contaminants. Samples taken from DH-2, DH-3, and DH-4 during August 1991 are the only ones that were analyzed for TCL constituents at Plot M. At that time, results showed no contamination above detection limits. The new wells at Plot $M$ should be monitored quarterly for a minimum of one year, and the samples should be analyzed for radionuclides and TCL constituents. After data have been collected for one year, the analytical list can be reduced to limit the costs of analysis.

As specified by the sampling protocol used by the ANL Environment and Waste Management Program, Sampling Subsurface Water from Plot M Boreholes, SCP-020 (December 1990), the groundwater samples collected for metals and tritium are filtered. Taken alone, these data do not present a complete picture. To detect the concentration of total metals (both dissolved and suspended), unfiltered samples must also be analyzed. Current research has shown that total metals reflect the migration of contaminants, whereas dissolved metals (found in filtered samples) are used to determine the toxicity of the metals (Puls and Barcelona 1989). Both filtered and unfiltered samples should be analyzed to determine both the migration of contaminants and their chemical interactions with the aquifer.

In addition, ANL has evaluated the existing monitoring wells to determine whether they are capable of providing samples that are representative of groundwater quality in the aquifers of concern. ANL's review focused mainly on well construction and the sampling program. Currently, the only sampling protocol used at Site A/Plot M is Sampling Subsurface Water from Plot M Boreholes, SCP-020 (December 1990), which was developed by the ANL Environment and Waste Management Program. This sampling protocol was developed to sample groundwater only for tritium analysis. It does not provide procedures for sampling the groundwater for TCL constituents. To ensure that representative samples are collected, a comprehensive, site-specific groundwater sampling and analysis program needs to be developed and implemented. 


\subsubsection{Groundwater Geochemistry}

The groundwater geochemistry of the area has not been fully characterized to determine the in-situ geochemical processes that affect contaminant migration. Precipitation/dissolution and adsorption/desorption reactions control migration of inorganic and organic solutes in soil and groundwater. These processes affect the mobility of heavy metals, radionuclides, and organics that have been released from the source area (Drever 1988; Longmuir and Mahoney 1984). Data have never been collected to characterize the soil/rock chemistry at the sites. These data are needed to establish the dominant processes occurring in the groundwater and to explain observed trends.

To fully understand the processes that control the migration of contaminants at Plot M, the following data should be collected:

- Mineralogy of major minerals and clays within the aquifers,

- $\mathrm{pH}$ of the soils,

- Total clay fraction of the soils,

- Cation exchange capacity of the aquifer material, and

- Exchangeable cations of the aquifer materials.

These data are required for the development of an accurate conceptual model of the aquifers that will show how the water/rock system interacts with the contaminants to produce the observed water composition.

\subsubsection{Site A}

\subsubsection{Groundwater Monitoring Wells}

Currently only one well, DH-1, is located on Site A. Plans exist to install four shallow, glacial drift wells and one bedrock well at the site (Mills 1991). ANL recommends that one additional monitoring well be installed at Site A beyond the well network proposed by the U.S. Geological Survey (USGS). This well should be located in the glacial till, near the burial site of the old reactor building. The screened interval should straddle the water table to detect any contaminants migrating from this area (EPA 1991). During the installation of this well, soil samples should be collected on 2.5-ft centers and analyzed for TCL constituents.

\subsubsection{Surface-Water Sampling}

The stream northwest of Site A should be sampled at four different locations for surface water and sediment samples, which should be analyzed for tritium. These samples 
are needed to locate the source of the tritium and potential contaminants that were found in the surface-water sample taken near the entrance to the site. Once the source is identified, additional samples and more analyses will be needed to determine the nature of the contamination.

\subsubsection{Soil Sampling}

During the installation of every new monitoring well at Site A, soil samples should be collected and analyzed for TCL and radioactive constituents. These results would be helpful in evaluating the nature and extent of contamination under and around Site A. Depending on the results of these analyses, additional borings may be required.

\subsubsection{Subsurface Radioactivity Survey}

A survey of subsurface radioactivity should be made in areas where increased levels of radioactivity were found, including suspect areas 5 and 6 (southeast of the Boiler House and the Well House), the southern part of suspect area 3, and the eastern and southern parts of suspect area 4. The survey should be done to a maximum of $10 \mathrm{ft}$, and it should concentrate on the most disturbed areas as defined by GPR. Depending on the survey results, additional borings and analysis may be required to determine the nature and extent of contamination in these soils.

\subsubsection{Groundwater Sampling and Analysis Program}

The sampling and analysis program needs to address a broader range of contaminants than the one that was previously undertaken. Samples taken from DH-1, a bedrock well, during August 1991 were analyzed for TCL constituents. At that time, acetone $(700 \mathrm{ppb})$ and methyl ethyl ketone $(140 \mathrm{ppb})$ were detected in the only well (DH-1) located at Site A. On the basis of those results, additional monitoring wells should be constructed in both the glacial till and the bedrock at Site A. These wells should be monitored quarterly for a minimum of one year, and the samples from them should be analyzed for TCL constituents and radionuclides. After data have been collected for one year, the program should be reviewed. If appropriate, the analytical list can be reduced to limit the cost of analysis.

As specified by the sampling protocol used by the ANL Environment and Waste Management Program, Sampling Subsurface Water from Plot M Boreholes, SCP-020 (December 1990), the groundwater samples collected for metals and tritium are filtered. As discussed in Section 8.2.1.3 for Plot M, these data do not present a complete picture without data from corresponding unfiltered samples. To determine both the migration of contaminants and their chemical interactions with the aquifer, both filtered and unfiltered samples should be analyzed. Also, as discussed in Section 8.2.1.3 for Plot M, a comprehensive, sitespecific groundwater sampling and analysis program needs to be developed and implemented. 


\subsubsection{Groundwater Geochemistry}

As was true of Site M, the groundwater geochemistry for Site A has not been fully characterized. Geochemical processes affect contaminant migration (Section 8.2.1.4). To understand fully how these processes operate at Site A, the following data should be collected:

- Mineralogy of major minerals and clays within the aquifers,

- $\mathrm{pH}$ of the soils,

- Total clay fraction of the soils,

- Cation exchange capacity of the aquifer material, and

- Exchangeable cations of the aquifer materials.

These data are required for the development of a true conceptual model of the aquifers that will show how the water/rock system interacts with the contaminants to produce the observed water composition. 


\section{REFERENCES}

Allen, R., 1992, personal communication from Allen (Illinois Department of Nuclear Safety, Springfield, Ill.) to C.R. Yuen (Argonne National Laboratory, Environmental Assessment and Information Sciences Division, Argonne, Ill.), Dec.

ANL, 1950a, "Background Information on the Argonne National Laboratory's UraniumGraphite Nuclear Reactor," information for press and radio, Argonne National Laboratory, Argonne, Ill., Nov. 24.

ANL, 1950b, "Background Information on the Argonne National Laboratory's Heavy Water Reactor," information for press and radio, Argonne National Laboratory, Argonne, Ill., Nov. 24.

ANL, 1979, Environmental Analysis of a Formerly Utilized MED/AEC Site, Site A and Plot M, Palos Forest Preserve, Palos Park, Illinois, ANL/ES-79, Argonne National Laboratory, Argonne, Ill.

Bianconi, J., 1991, memorandum from Bianconi (Illinois Department of Nuclear Safety, Springfield, Ill.) to D. McGinty (Forest Preserve District of Cook County), Dec. 30.

DOE, 1990, Site A disposal record, in Weekly and Special Reports (updated 10/16/90), U.S Department of Energy.

Drever, J.I., 1988, The Geochemistry of Natural Waters, 2nd. ed. Prentice Hall, Englewood Cliffs, N.J.

EPA, 1987, Contract Laboratory Program, Statement of Work for Analysis, U.S Environmental Protection Agency, Washington, D.C., Aug.

EPA, 1991, Handbook of Suggested Practices for the Design and Installation of Ground-Water Monitoring Wells, U.S Environmental Protection Agency, Office of Research and Development, Washington D.C., March.

Glasstone, S., 1955, Principles of Nuclear Reactor Engineering, D. Van Nostrand Company, Inc., N.Y.

Golchert, N.W., 1987, Site Surveillance and Maintenance Program for Palos Park: Report for 1986, ANL-87-8, Argonne National Laboratory, Argonne, Ill.

Golchert, N.W., 1988, Site Surveillance and Maintenance Program for Palos Park: Report for 1987, ANL-88-12, Argonne National Laboratory, Argonne, Ill.

Golchert, N.W., 1989, Site Surveillance and Maintenance Program for Palos Park: Report for 1988, ANL-89-7, Argonne National Laboratory, Argonne, Ill. 
Golchert, N.W., 1990, Surveillance of Site A and Plot M: Report for 1989, ANL-90/7, Argonne National Laboratory, Argonne, Ill.

Golchert, N.W., 1991, Surveillance of Site A and Plot M: Report for 1990, ANL-91/2, Argonne National Laboratory, Argonne, Ill.

Golchert, N.W., 1992, Surveillance of Site A and Plot M: Report for 1991, ANL-92/13, Argonne National Laboratory, Argonne, Ill.

Golchert, N.W., 1993, personal communication from Golchert (Argonne National Laboratory, Argonne, Ill.), to C.R. Yuen (Argonne National Laboratory, Argonne, Ill.), March 19.

Golchert, N.W., and J. Sedlet, 1977, Radiological Survey of Site $A$ and Plot $M$, DOE/EV-0005/7, prepared by Argonne National Laboratory, Argonne, Ill., for the U.S. Department of Energy, April.

Golchert, N.W., and J. Sedlet, 1984a, unpublished information, Argonne National Laboratory, Argonne, Ill., available from the authors.

Golchert, N.W., and J. Sedlet, 1984b, unpublished information, Argonne National Laboratory, Argonne, Ill., available from the authors.

Golchert, N.W., and J. Sedlet, 1985, unpublished information, Argonne National Laboratory, Argonne, Ill., available from the authors.

Golchert, N.W., and J. Sedlet, 1986, Site Surveillance and Maintenance Program for Palos Park: Report for 1985, ANL-86-25, prepared by Argonne National Laboratory, Argonne, Ill., for the U.S. Department of Energy.

Golchert, N.W., et al., 1983, Environmental Surveillance of the Palos Park Forest Preserve, ANL-83-6, Argonne National Laboratory, Argonne, Ill.

Illinois Geological Survey, 1992, well logs of DH-1 (Cook County well log \#25397) and W5195 (Cook County well log \#2144), Urbana, Ill.

Lonergan, G.T., 1958, "Radiation Monitoring of Reactor Demolition," Argonne National Laboratory, April. Also presented at the American Industrial Hygiene Association Convention in Atlantic City, N.J., April 21-25.

Longmuir, D., and J. Mahoney, 1984, Chemical Equilibrium and Kinetics of Geochemical Processes in Ground Water Studies, proceedings of the First Canadian/American Conference on Hydrogeology, June, pp. 69-95.

McKinley, J.H., 1956, letter from J.H. McKinley (Business Manager, Argonne National Laboratory, Argonne Ill.) to D. Saxe (Director, Development Contracts Division, Chicago Operations Office, U.S. Atomic Energy Commission), April 2. Attached to the letter is an 
April 2, 1956, report entitled "Composite Radiation Safety Report on Site A as of February 01, 1956."

Mills, P., 1991, memorandum from Mills (U.S. Geological Survey, Urbana, Ill.) to J. Hunze, (U.S. Department of Energy, Chicago Field Office, Argonne, Ill.), Feb. 25.

Nicholas, J.R., and R.W. Healy, 1988, Tritium Migration from a Low-Level Radioactive-Waste Disposal Site near Chicago, Illinois, Water-Supply Paper 2333, U.S. Geological Survey.

Olimpio, J.C., 1982, Data for Wells at the Low-Level Radioactive-Waste Burial Site in the Palos Forest Preserve, Illinois, Open-File Report 82-692, U.S. Geological Survey.

Olimpio, J.C., 1984, Low-Level Radioactive-Waste Burial at the Palos Forest Preserve, Illinois: Geology and Hydrology of the Glacial Drift, Water-Supply Paper 2226, U.S. Geological Survey.

ORAU, 1990, Status Report, Phase 1 Radiological Survey: Palos Park Forest Preserve Site, Cook County, Illinois, ORAU 90/K-78, prepared by Oak Ridge Associated Universities for the Decontamination and Decommissioning Division, U.S. Department of Energy.

ORAU, 1991, Update of Phase 1 and Phase 2 Activities, Palos Forest Preserve Site Survey, Cook County, Illinois, prepared by Oak Ridge Associated Universities for the Decontamination and Decommissioning Division, U.S. Department of Energy.

ORISE, 1993, Radionuclide Concentrations in Samples from Shallow Boreholes, Palos Park Forest Preserve Site, Cook County, Illinois, Oak Ridge Institute for Science and Education, Oak Ridge, Tenn.

ORNL, 1989, Argonne National Laboratory, Sampling and Analysis Data Document, ORNL/TM-11203, vol. 1, Oak Ridge National Laboratory, Oak Ridge, Tenn.

Puls, R.W., and M.J. Barcelona, 1989, Ground Water Sampling for Metals Analyses, U.S. Environmental Protection Agency, Office of Research and Development, Washington, D.C., March.

Sosebee, J.B., et al., 1983, Contamination of Groundwater Samples with PVC Adhesives and PVC Primer from Monitoring Wells, proceedings of the ASTM Second Symposium on Hazardous and Solid Waste Testing, ASTM STP \#805, R.A. Conway and W.P. Gulledge (editors), American Society for Testing and Materials, Philadelphia, Penn., pp. 38-50.

Sugden, D.E., and B.S. John, 1976, Glaciers and Landscape, John Wiley \& Sons, N.Y.

Tyrell, W.J., et al., 1961, "Notes on Decontamination of Surface and Equipment," Argonne National Laboratory, Argonne, Ill., April.

William, H.B., 1973, Geology along the Illinois Waterway: A Basis for Environmental Planning, Circular 487, Illinois Geological Survey. 
Young, C.A., 1948, "Radioactive Waste Disposal," interoffice memorandum from Young, Safety Engineer, to H.L. Hall, Associate Director (Argonne National Laboratory, Argonne, Ill.), May 6. 


\section{BIBLIOGRAPHY FOR SECTION 2.1}

ANL, 1950a, "Background Information on the Argonne National Laboratory's UraniumGraphite Nuclear Reactor," information for press and radio, Argonne National Laboratory, Argonne, Ill., Nov. 24.

ANL, 1950b, "Background Information on the Argonne National Laboratory's Heavy Water Reactor," information for press and radio, Argonne National Laboratory, Argonne, Ill., Nov. 24.

ANL, 1979, Environmental Analysis of a Formerly Utilized MED/AEC Site, Site A and Plot M, Palos Forest Preserve, Palos Park, Illinois, ANL/ES-79, Argonne National Laboratory, Argonne, Ill., Sept.

Avci, H., 1992/93, personal interviews by Halil Avci (Environmental Assessment and Information Sciences Division, Argonne National Laboratory) of the following individuals who either worked at Site A or visited Site A on a regular basis while the site was in operation:

Al Wattenberg, November 16, 1992

Harold Lichtenberger, November 17, 1992

Ed Wimunc, November 05, 1992

Paul Persiani, November 25, 1992

Don Gardener, November 30, 1992

Walter Zinn, March 16, 1993 (by telephone)

DOE, 1991, Environmental Restoration and Waste Management Site Specific Plan: Volume XI, Site A/Plot M, U.S. Department of Energy, Chicago Field Office, July.

EPA, 1988, "Environmental Survey Preliminary Report, Argonne National Laboratory, Argonne, Mlinois," DOE/EH/OEV-17-P, U.S. Department of Energy, Environment, Safety and Health, Office of Environmental Audits, Nov.

Glasstone, S., 1955, Principles of Nuclear Reactor Engineering, D. Van Nostrand Company, Inc., N.Y.

Golchert, N.W., 1993, personal communication from Golchert (Argonne National Laboratory) to C.R. Yuen (Argonne National Laboratory), Mar. 19.

Lonergan, G.T., 1955, "Radiation Monitoring of Reactor Demolition," Argonne National Laboratory, April. Also presented at the American Industrial Hygiene Association Convention in Atlantic City, N.J., April 21-25.

McKinley, J.H., 1956, letter from McKinley (Business Manager, Argonne National Laboratory) to D. Saxe (Director, Development Contracts Division, Chicago Operations Office, U.S. Atomic Energy Commission), April 2. Attached to the letter is an April 2, 1956 report entitled "Composite Radiation Safety Report on Site A as of February 01, 1956." 
Smyth, H.D., Atomic Energy for Military Purposes, Princeton University Press, Princeton, N.J., 1948.

Tyrell, W.J., et al., 1961, "Notes on Decontamination of Surface and Equipment," Argonne National Laboratory, Argonne, Ill., April.

Young, C.A., 1948, "Radioactive Waste Disposal," interoffice memorandum from Young, Safety Engineer, to H.L. Hall, Associate Director (Argonne National Laboratory, Argonne, Ill.), May 6. 


\section{APPENDIX A:}

MEMORANDUM ON RADIOACTIVE WASTE DISPOSAL AT ARGONNE NATIONAL LABORATORY, MAY 6, 1948 


\section{APPENDIX A: \\ MEMORANDUM ON RADIOACTIVE WASTE DISPOSAL AT ARGONNE NATIONAL LABORATORY, MAY 6, 1948}

This appendix presents a memorandum dated May 6, 1948, from C.A. Young, Safety Engineer, to H.L. Hall, Associate Director, Argonne National Laboratory, on the subject of radioactive waste disposal

The best available copy of the original is presented in the boxed exhibits, as material of historical interest. Because the quality of the copy is so poor, the full text has been recreated and appears after the exhibits.

The additional materials mentioned in items 5 and 19 (the last two enclosures listed at the end of the memo) were not available to the authors of this report. 


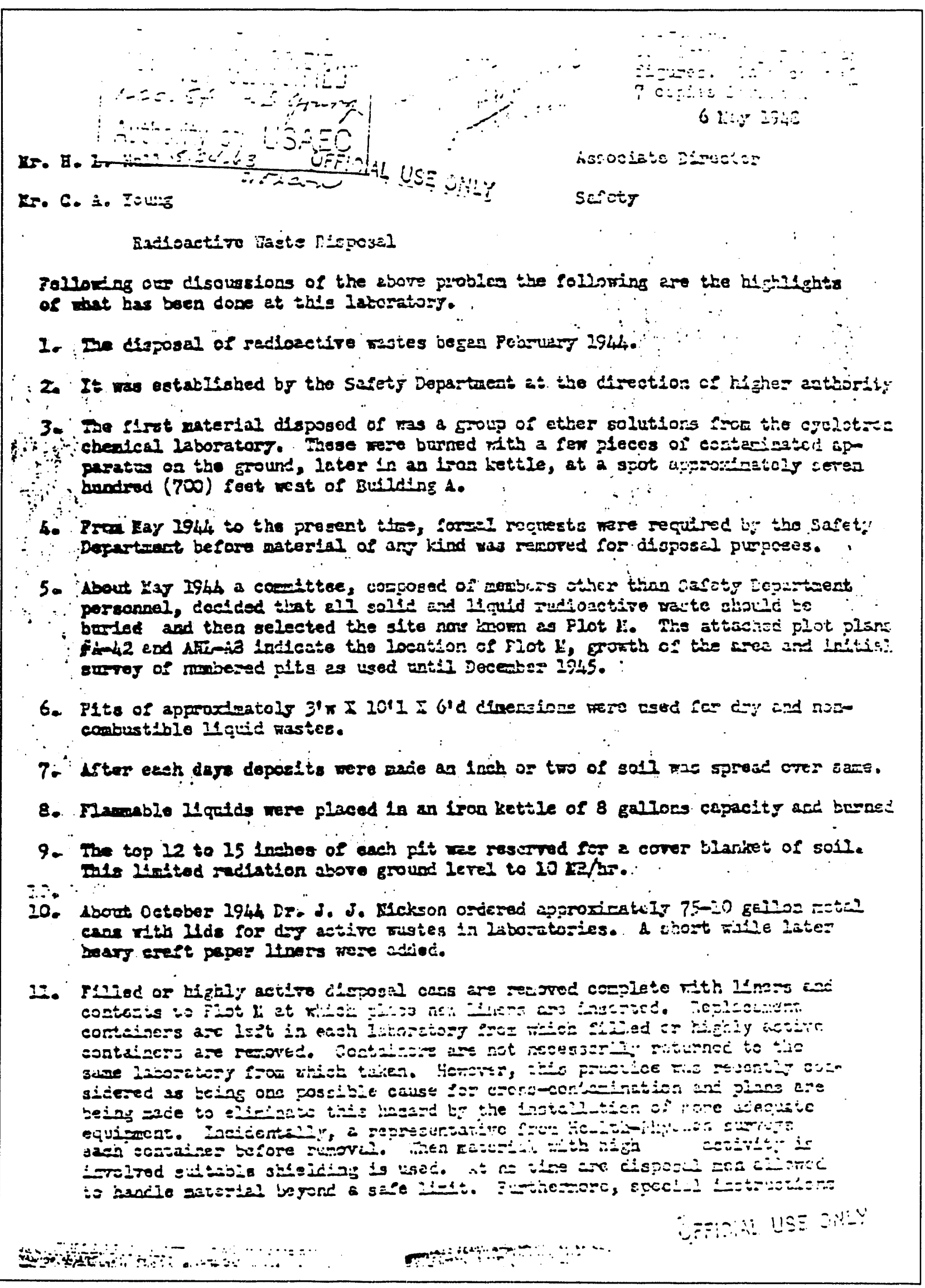




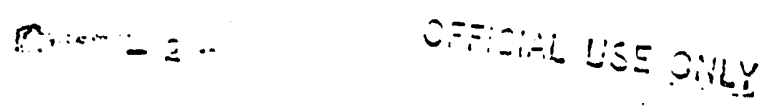

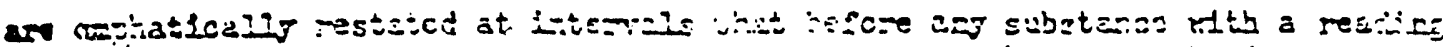

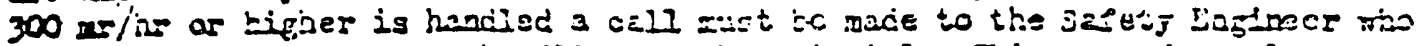

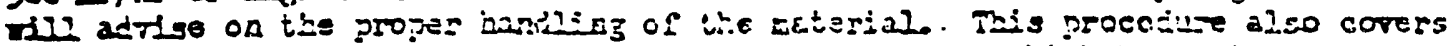

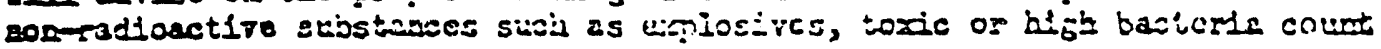
satarials.

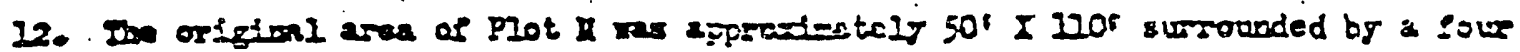
strand barbed vire fanes.

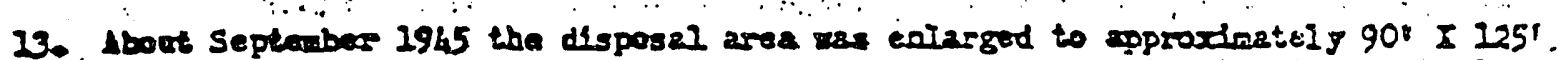

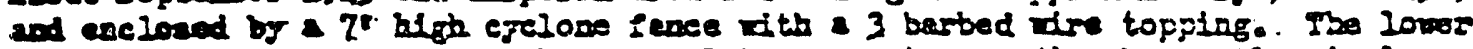
I8" ins furtbor anclosed by sbeet netsl to preront mareodsog by soell animals.

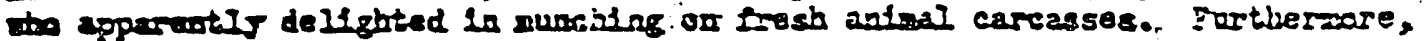

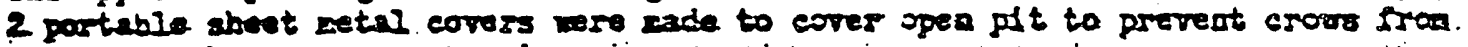

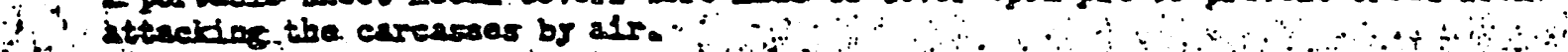

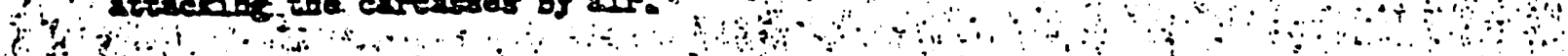

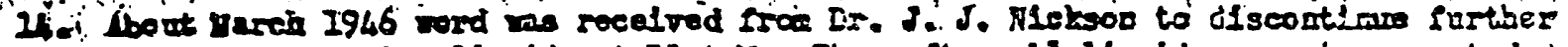

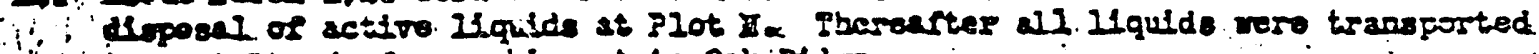

i"! to West Stands for nubipment to Cak gld ge.

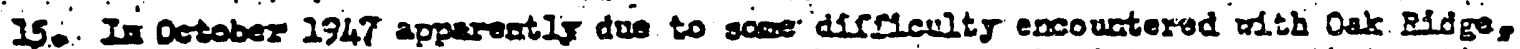

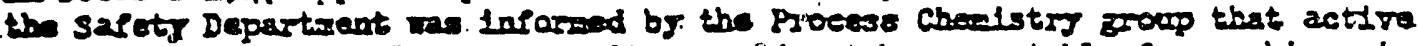
colutions other laboratory sites would not bo accoptabie for resbiponent

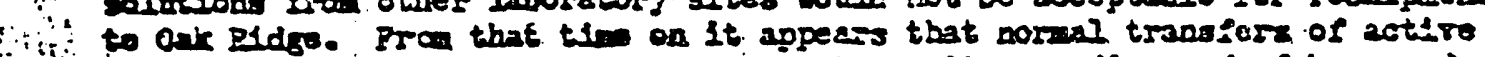
rubods soch as dow drains or aboorbed by dry vaterial in actipo rasto cans.

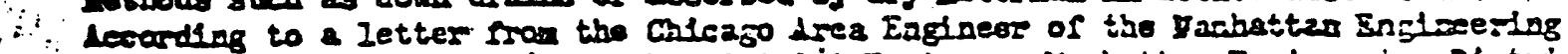

is DIstrict December 9, 2946, to tho District Eofioeer, laninattan Engigoering Ilstric

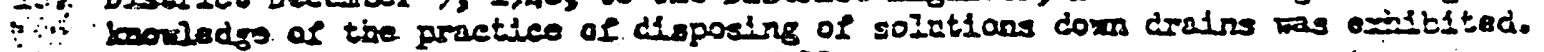
Tre covefing specificstious wors as follons:

(a) letirity best bo bolor 1 sterocmle per Iltse.

(b). The solution mat be clear and albatine.

(c) Drato oolr through derdgated server openings wheb aro selected for

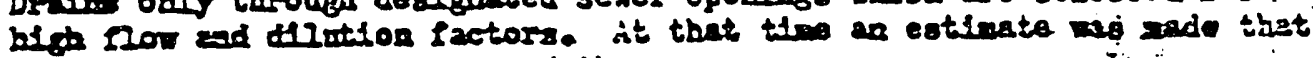
somaral Ittrea par day entersed the sewers.

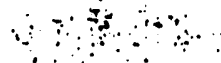

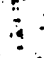

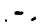

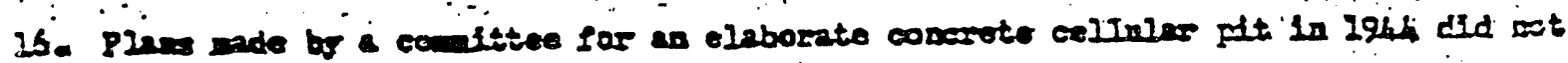
nteristre.

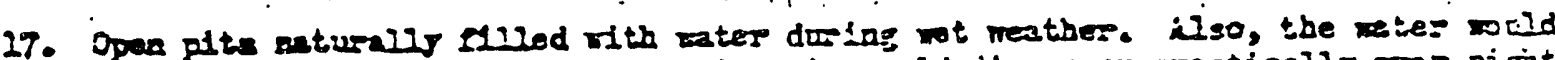
sowstimes stand for a weok; otherises it wuld desppeer practically over aigit.

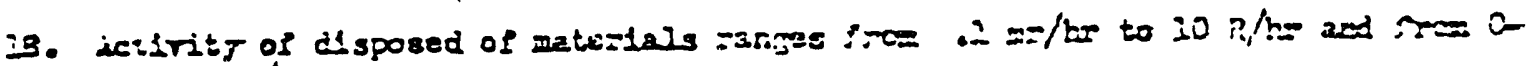
$800,200 \mathrm{~d} / 20$

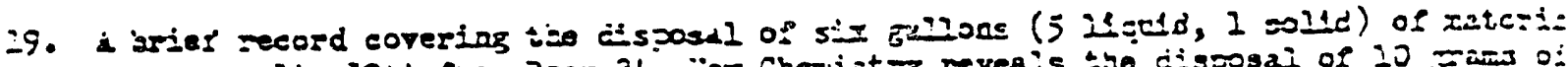

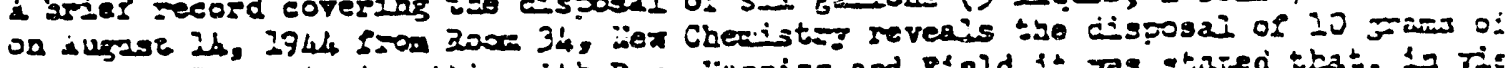

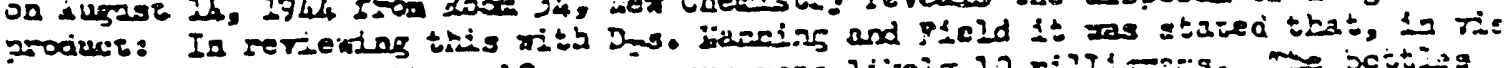

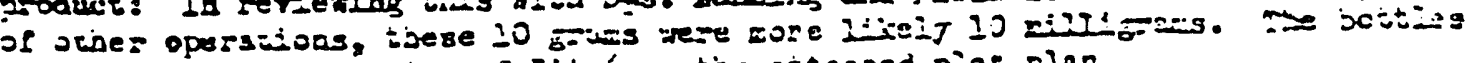

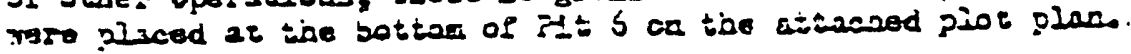

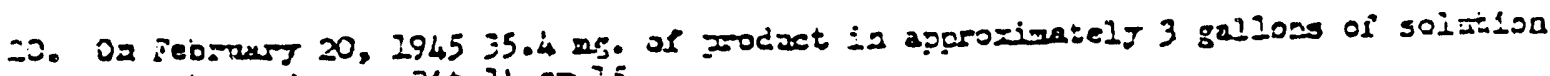
20ro burzed pear P4t 24 or $=5$.

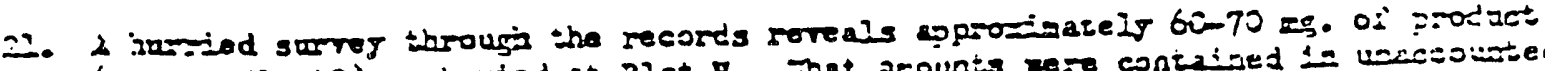

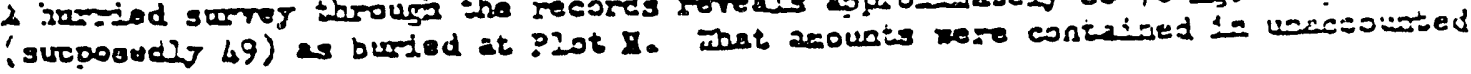




\section{$=3-$}

for solutions ean aniy bestiosted.

22. Botroen sagust 1944 ad hareh 2946 all julutions woro lefe intact in botiles or earboys aslose save fractored darios or aiter placesont in pits.

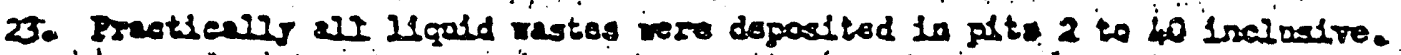

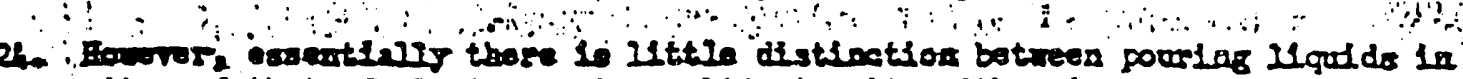

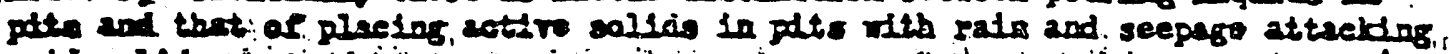

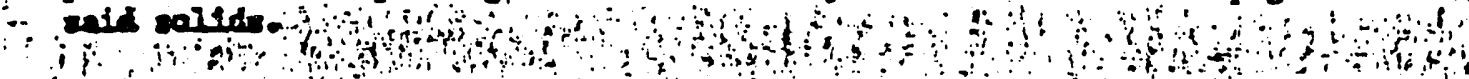

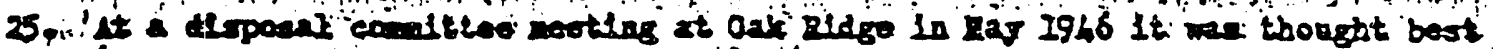

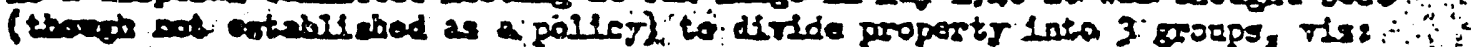

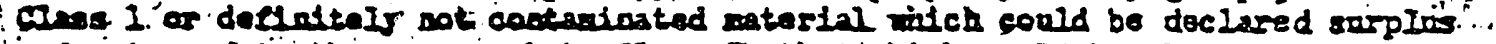

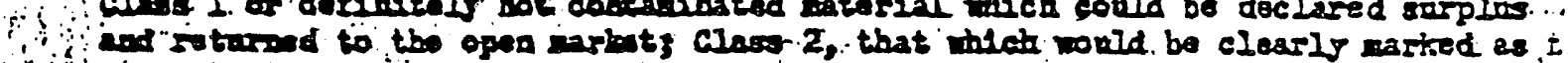

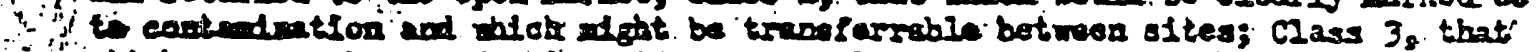

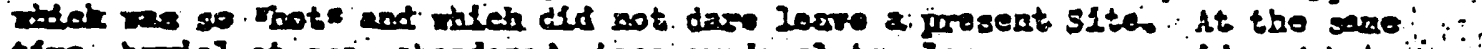

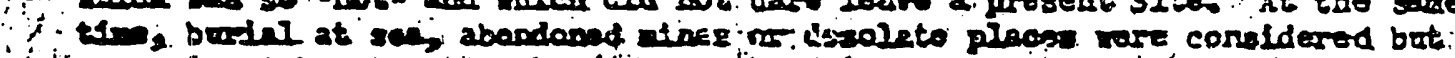

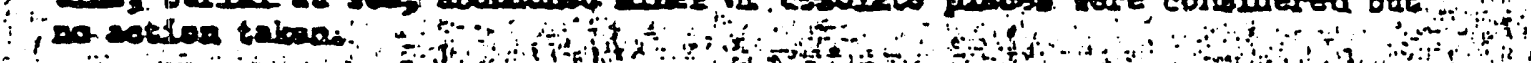
(

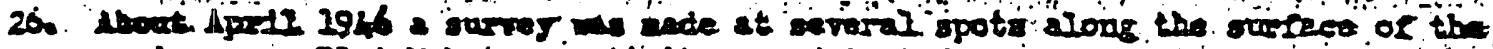
ravleo vair PIot 1 but Do ectidity was detocted.

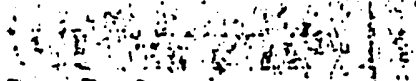

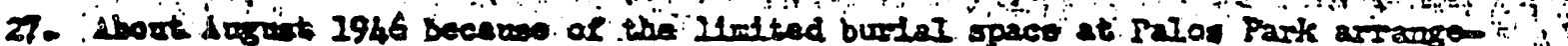

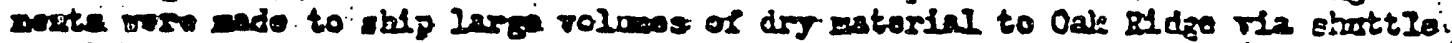

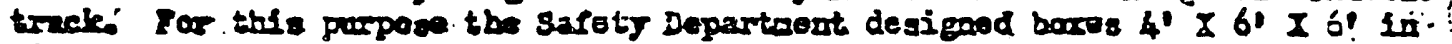

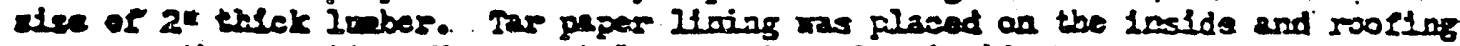
papor on tho urtatide. Ieary potal strapping pils loolde bzaces sufforted the

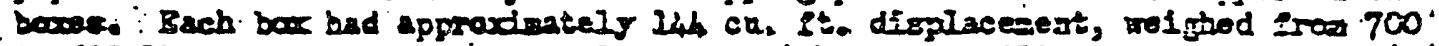

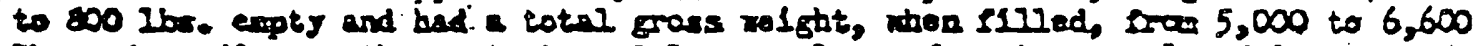

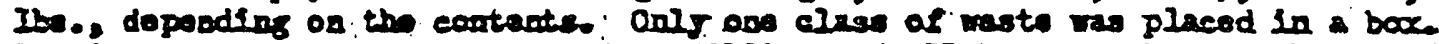

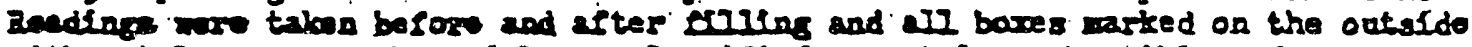

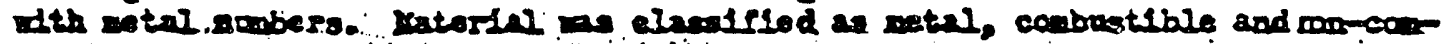

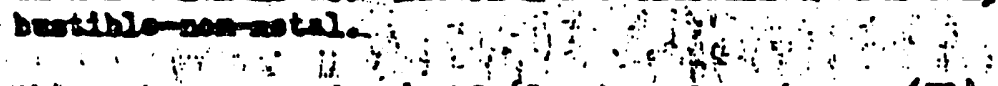

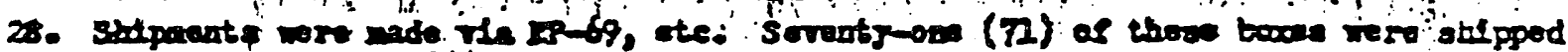

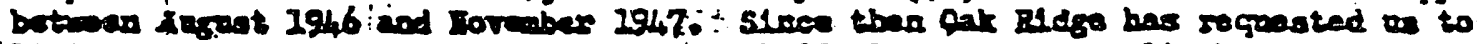

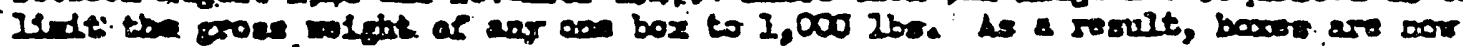

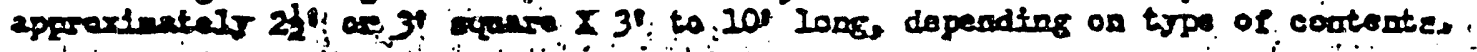

39. totel mber of pits used to date at p20t II number 94. Ints represents

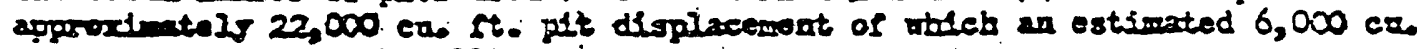

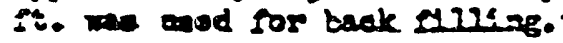

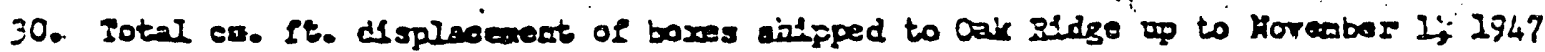
is 10,224 er. It.

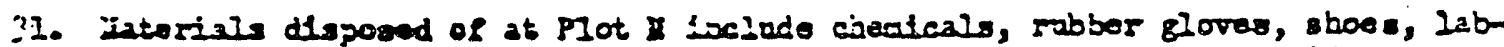

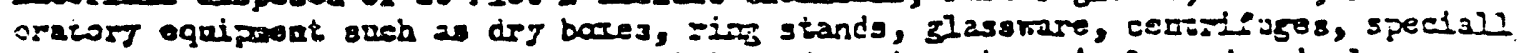

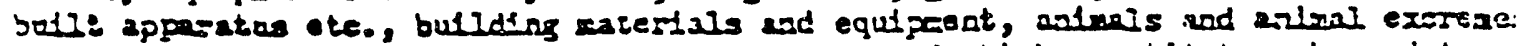

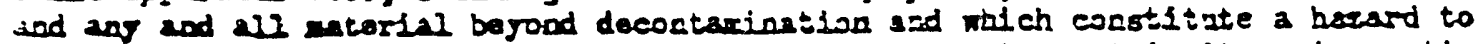
sealih or expafienta. To attemot was mice to segregato coriaio 1 ters 10 particul pits. 


\section{prever:}

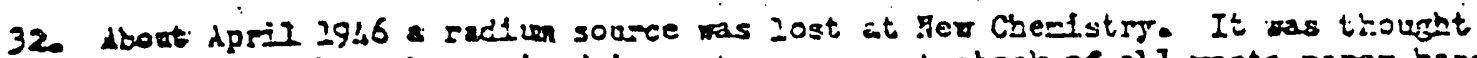

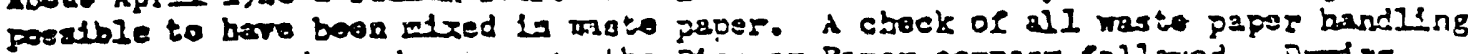
procedere wes rado and a irg; to the Ploneer Peper conpagr followed. Iorlag

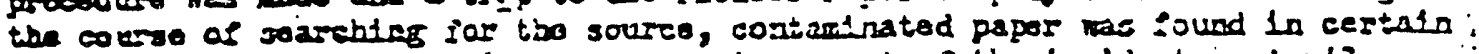

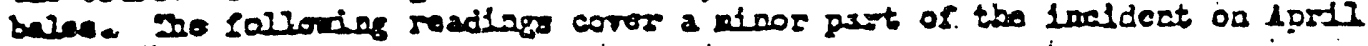
22. 2946i:

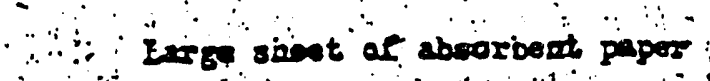

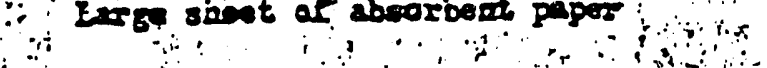

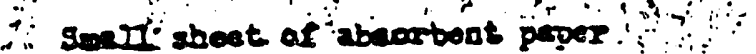

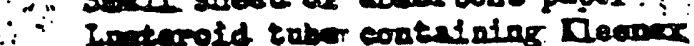

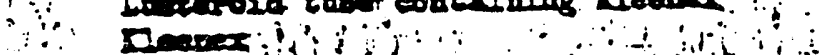

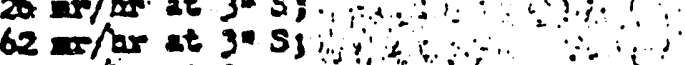

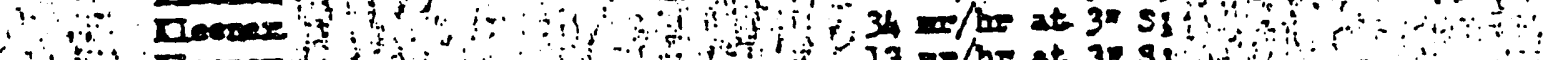

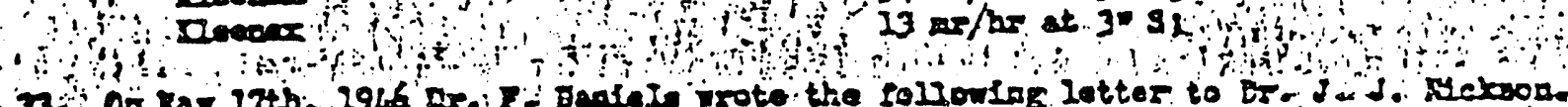

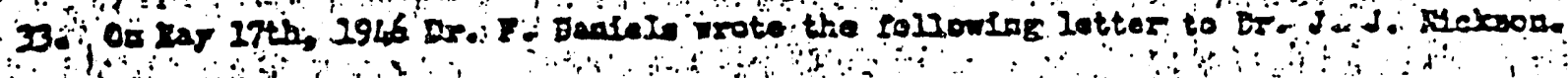

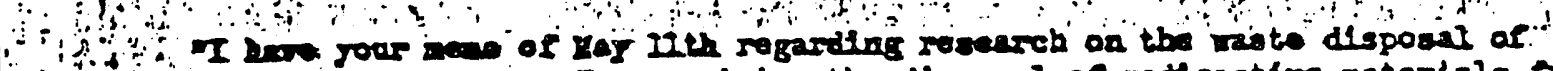

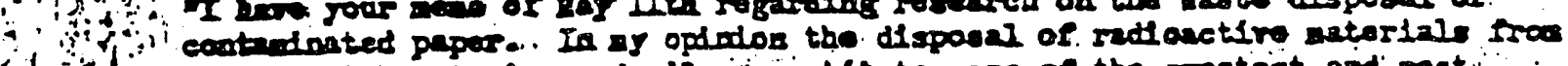

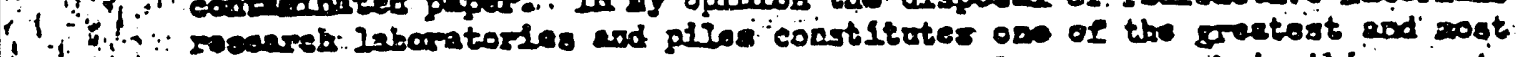

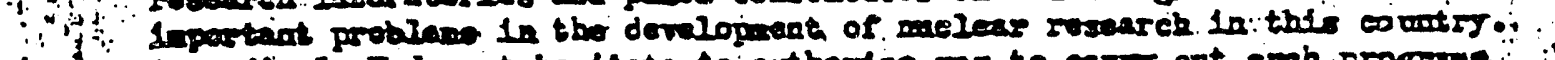

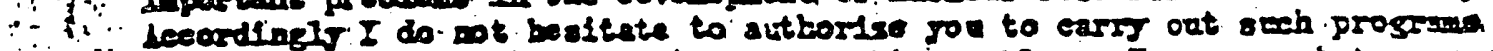

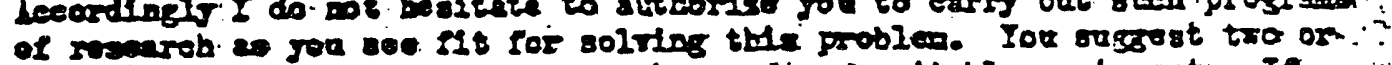

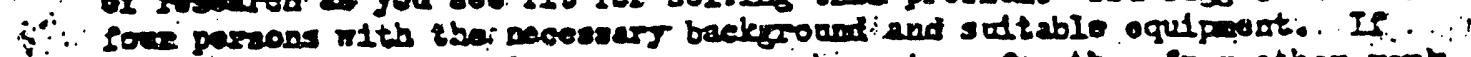

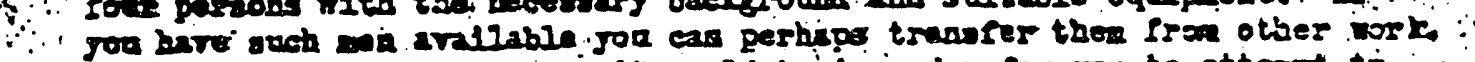

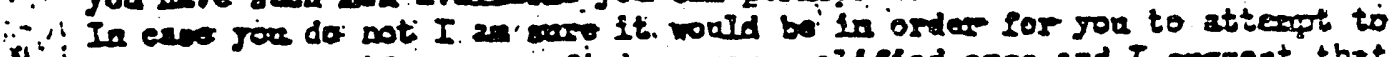

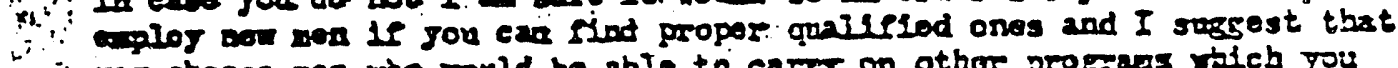

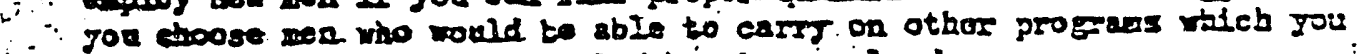

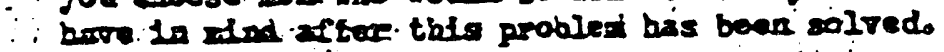

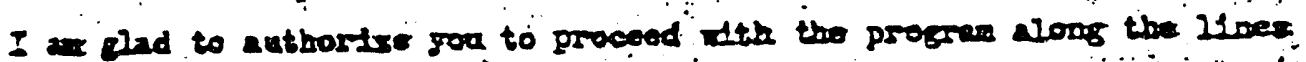

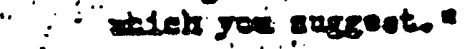

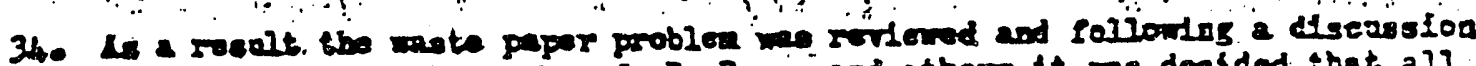

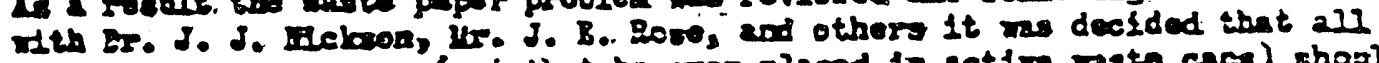
laborstary we paper (not that towerer plaoed in actiro wasto caca) sbogld

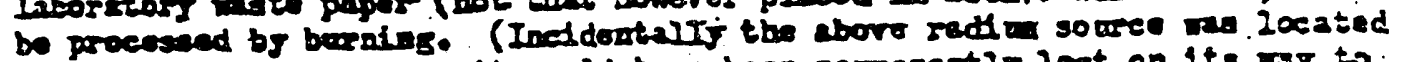

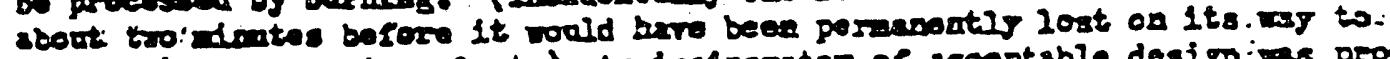

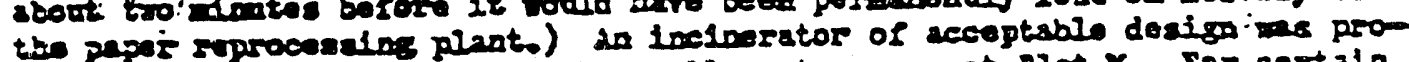

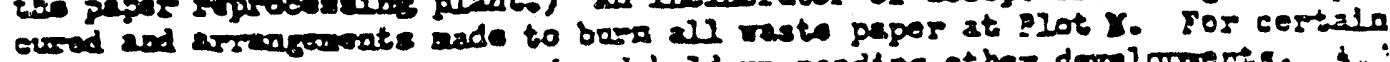

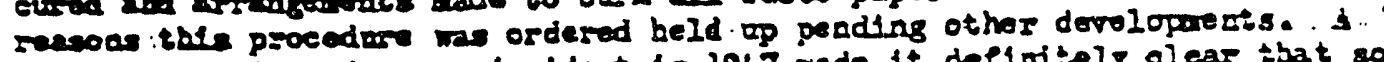

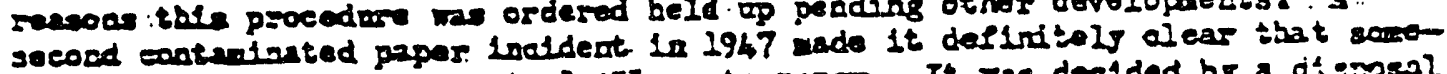

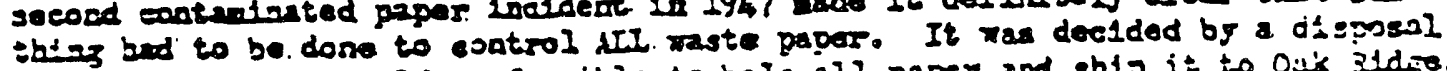

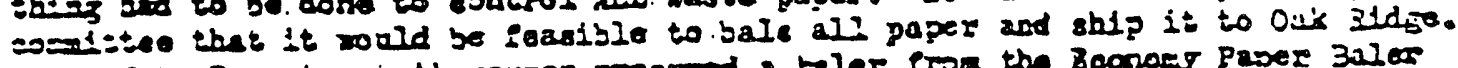

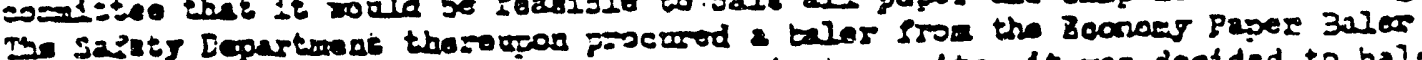

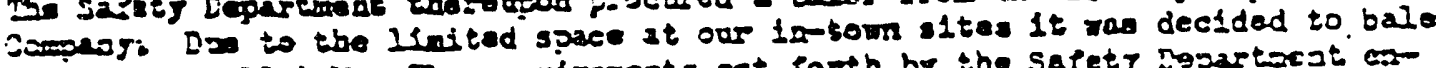

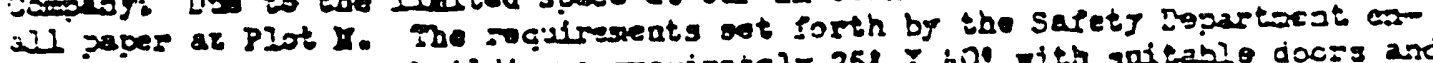

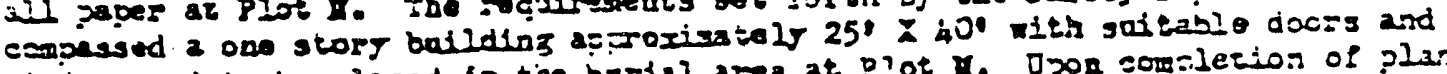

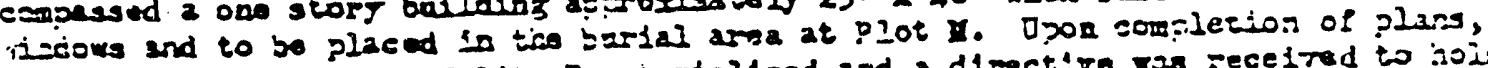

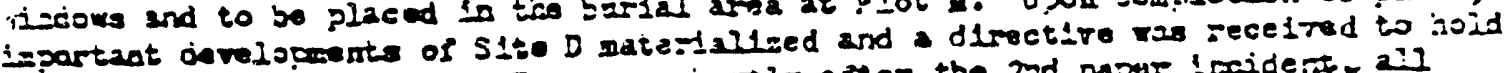

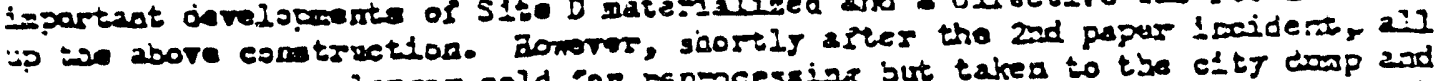

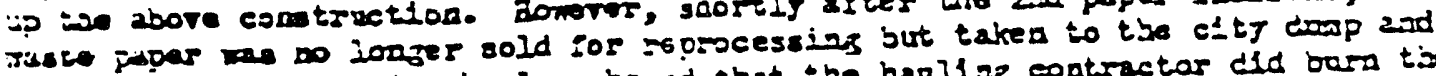

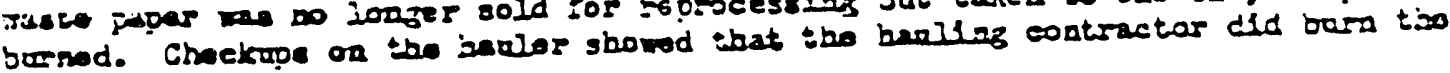
papers as per onders.

35. I הovmoer 1947 P20t $x$ was oalargod bs appoxtantols 501 I 1251. 


\section{$-5=$}

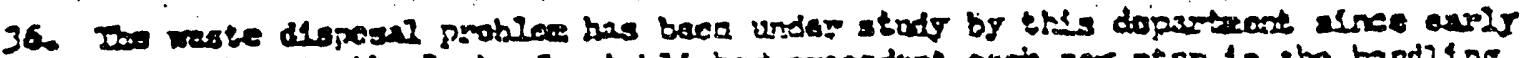

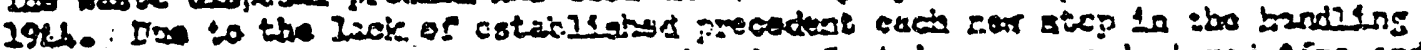

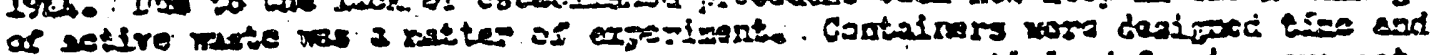

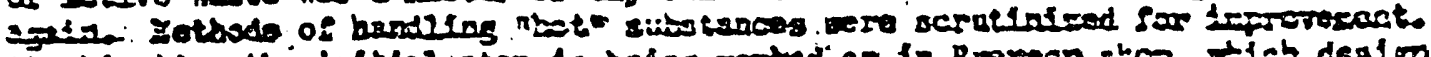

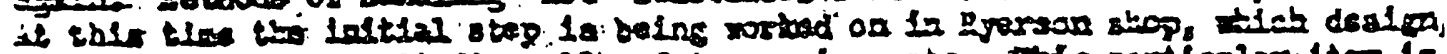

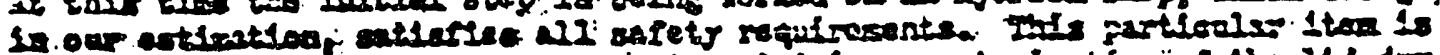

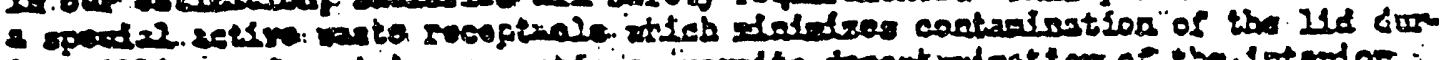

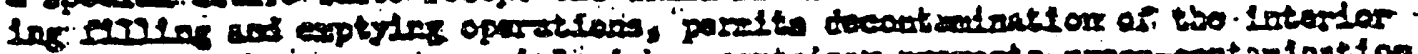

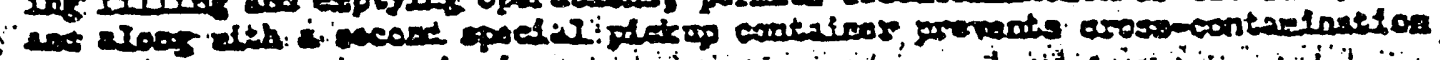

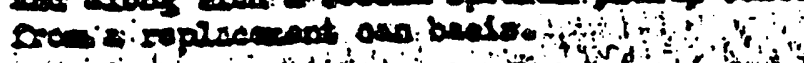

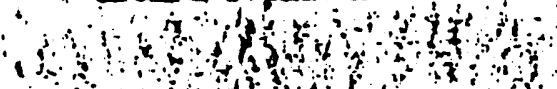

$\because$

(1)

aristis

Q

(a)

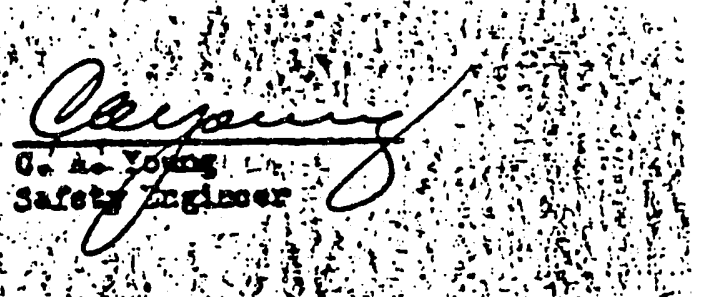

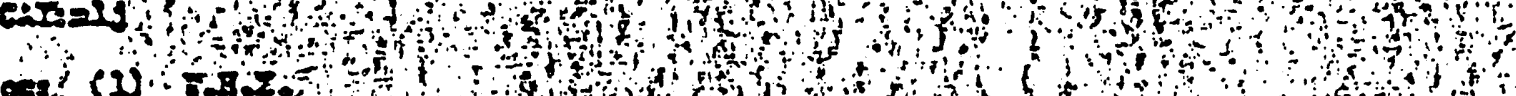

os (1)

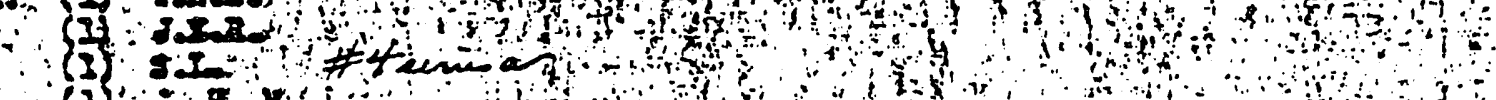

(1): 5. 5. 216

$4+4$ of

feners: I las beot

I 2 int 12

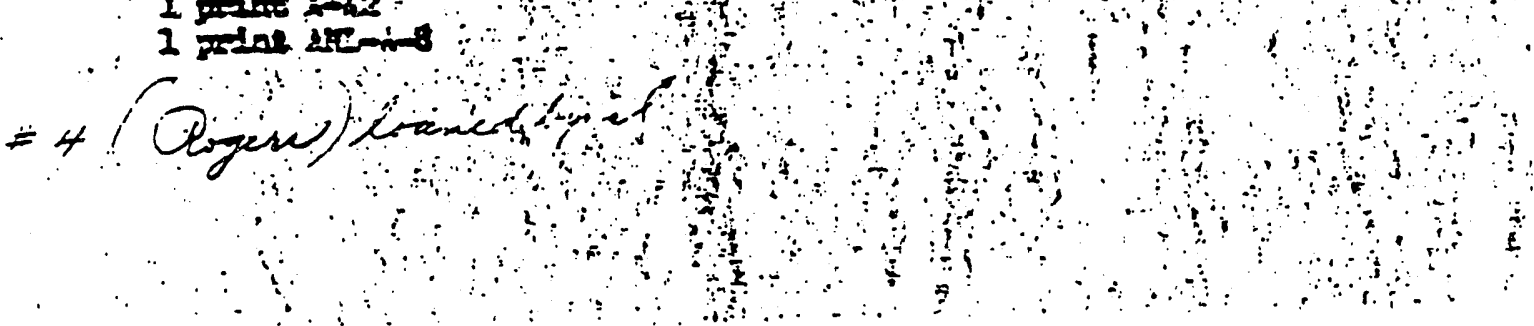




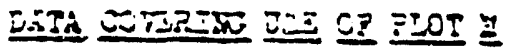

ordend piat sted (550 I 1000$)$.

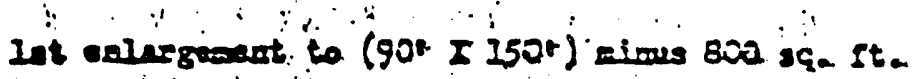

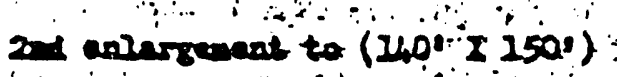

- of jots (to datol

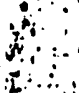

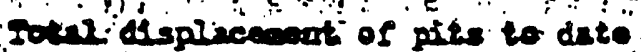

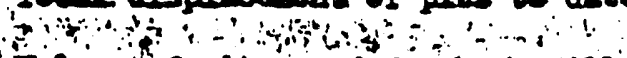

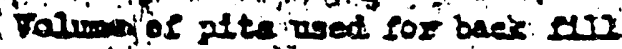

$$
\text { a la a a }
$$

Let polino of deposed of rational

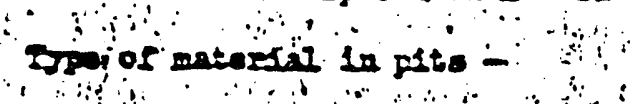

$\because \because \because$

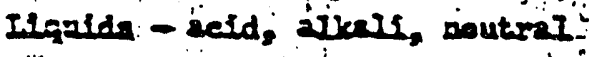

$\therefore \div$

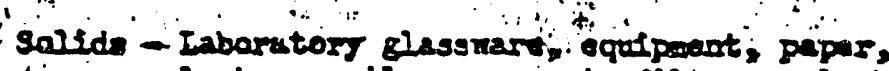

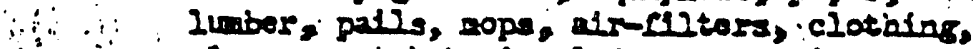

gloves, catch bas iz alndgo, magnesín chtps,

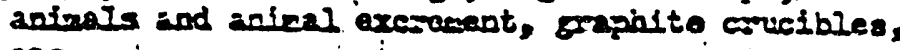

ose.

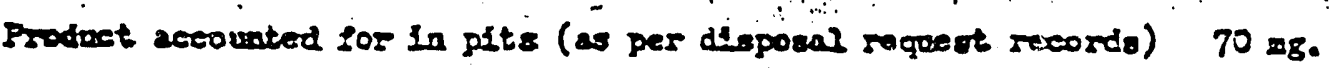

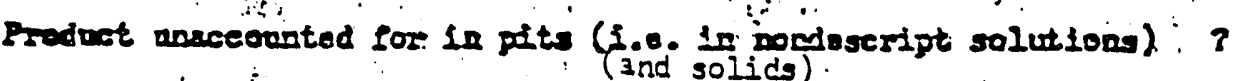

Ifquatos Indted to pits:

Llopids paceod in pits tras

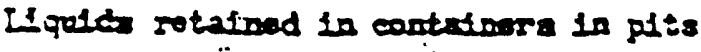

Eatianted gasentity of ilqusds in fits

detsrits range

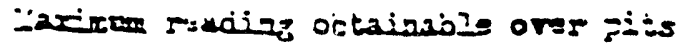

Do. 2 to about 35

2a. 2 ta 6

Io. 7 to $35^{\circ}$

500 galsons

$0-600,000 d / 2$

20 $0 \mathrm{a} / \mathrm{hr}$.

$10 \mathrm{me} / \mathrm{ha}$.

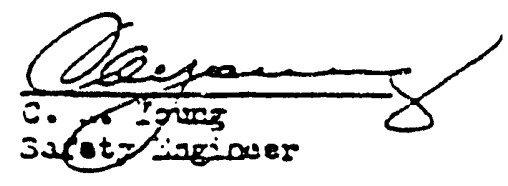


Mr. H. L. Hall

Mr. C. A. Young

Associate Director Safety

Radioactive Waste Disposal

Following our discussions of the above problem the following are the highlights of what has been done at this laboratory.

1. The disposal of radioactive wastes began February 1944.

2. It was established by the Safety Department at the direction of higher authority.

3. The first material disposed of was a group of ether solutions from the cyclotron chemical laboratory. These were burned with a few pieces of contaminated apparatus on the ground, later in an iron kettle, at a spot approximately seven hundred (700) feet west of Building A.

4. From May 1944 to the present time, formal requests were required by the Safety Department before material of any kind was removed for disposal purposes.

5. About May 1944 a committee, composed of members other than Safety Department personnel, decided that all solid and liquid radioactive waste should be buried and then selected the site now known as Plot $M$. The attached plot plans \#A-42 and ANL-A8 indicate the location of Plot $M$, growth of the area and initial survey of numbered pits as used until December 1945.

6. Pits of approximately $3^{\prime} \mathrm{w} \times 10^{\prime} 1 \times 6^{\prime} \mathrm{d}$ dimensions were used for dry and noncombustible liquid wastes.

7. After each days deposits were made an inch or two of soil was spread over same.

8. Flammable liquids were placed in an iron kettle of 8 gallons capacity and burned.

9. The top 12 to 15 inches of each pit was reserved for a cover blanket of soil. This limited radiation above ground level to $10 \mathrm{mR} / \mathrm{hr}$.

10. About October 1944 Dr. J.J. Nickson ordered approximately 75-10 gallon metal cans with lids for dry active wastes in laboratories. A short while later heavy craft paper liners were added.

11. Filled or highly active disposal cans are removed complete with liners and contents to Plot $M$ at which place new liners are inserted. Replacement containers are left in each laboratory from which filled or highly active containers are removed. Containers are not necessarily returned to the same laboratory from which taken. However, this practice was recently considered as being 
one possible cause for cross-contamination and plans are being made to eliminate this hazard by the installation of more adequate equipment. Incidentally, a representative from Health-Physics surveys each container before removal. When material with high activity is involved suitable shielding is used. At no time are disposal men allowed to handle material beyond a safe limit. Furthermore, special instructions are emphatically restated at intervals that before any substance with a reading $300 \mathrm{mr} / \mathrm{hr}$ or higher is handled a call must be made to the Safety Engineer who will advise on the proper handling of the material. This procedure also covers non-radioactive substances such as explosives, toxic or high bacteria count materials.

12. The original area of $\mathrm{P}$ lot $\mathrm{M}$ was approximately $50^{\prime} \times 110^{\prime}$ surrounded by a four strand barbed wire fence.

13. About September 1945 the disposal area was enlarged to approximately $90^{\prime} \times 125^{\prime}$ and enclosed by a $7^{\prime}$ high cyclone fence with a 3 barbed wire topping. The lower 18" was further enclosed by sheet metal to prevent marauding by small animals who apparently delighted in munching on fresh animal carcasses. Furthermore, 2 portable sheet metal covers were made to cover open pit to prevent crows from attacking the carcasses by air.

14. About March 1946 word was received from Dr. J.J. Nickson to discontinue further disposal of active liquids at Plot $\mathrm{M}$. Thereafter all liquids were transported to West stands for reshipment to Oak Ridge.

15. In October 1947 apparently due to some difficulty encountered with Oak Ridge, the Safety Department was informed by the Process Chemistry group that active solutions from other laboratory sites would not be acceptable for reshipment to Oak Ridge. From that time on it appears that normal transfers of active solutions are either being stored at various sites or disposed of by unendorsed methods such as down drains or absorbed by dry material in active waste cans. According to a letter from the Chicago Area Engineer of the Manhattan Engineering District December 9, 1946, to the District Engineer, Manhattan Engineering District knowledge of the practice of disposing of solutions down drains was exhibited. The covering specifications were as follows:

(a) Activity must be below 1 microcurie per liter.

(b) The solution must be clear and alkaline.

(c) Drains only through designated sewer openings which are selected for high flow and dilution factors. At that time an estimate was made that several liters per day entered the sewers.

16. Plans made by a committee for an elaborate concrete cellular pit in 1944 did not materialize.

17. Open pits naturally filled with water during wet weather. Also, the water would sometimes stand for a week; other times it would disappear practically over night. 
18. Activity of disposed of materials ranges from $.1 \mathrm{mr} / \mathrm{hr}$ to $10 \mathrm{R} / \mathrm{hr}$ and from $0-600,000 \mathrm{~d} / \mathrm{m}$.

19. A brief record covering the disposal of six gallons ( 5 liquid, 1 solid) of materials on August 14, 1944 from Room 34, New Chemistry reveals the disposal of 10 grams of product: In reviewing this with Drs. Hanning and Field it was stated that, in view of other operations, these 10 grams were more likely 10 milligrams. The bottles were placed at the bottom of Pit 6 on the attached plot plan.

20. On February, $194535.4 \mathrm{mg}$. of product in approximately 3 gallons of solution were buried near Pit 14 or 15 .

21. A hurried survey through the records reveals approximately 60-70 mg. of product (supposedly 49) as buried at Plot M. What amounts were contained in unaccounted for solutions can only be estimated.

22. Between August 1944 and March 1946 all solutions were left intact in bottles or carboys unless same fractured during or after placement in pits.

23. Practically all liquid wastes were deposited in pits 2 to 40 inclusive.

24. However, essentially there is little distinction between pouring liquids in pits and that of placing active solids in pits with rain and seepage attacking said solids.

25. At a disposal committee meeting at Oak Ridge in May 1946 it was thought best (though not established as a policy) to divide property into 3 groups, viz: Class 1 or definitely not contaminated material which could be declared surplus and returned to the open market; Class 2, that which would be clearly marked as to contamination and which might be transferrable between sites; Class 3, that which was so "hot" and which did not dare leave a present site. At the same time, burial at sea, abandoned mines or desolate places were considered but no action taken.

26. About April 1946 a survey was made at several spots along the surface of the ravine near Plot $M$ but no activity was detected.

27. About August 1946 because of the limited burial space at Palos Park arrangements were made to ship large volumes of dry material to Oak Ridge via shuttle truck. For this purpose the Safety Department designed boxes $4^{\prime} \times 6^{\prime} \times 6^{\prime}$ in size of $2^{\prime \prime}$ thick lumber. Tar paper lining was placed on the inside and roofing paper on the outside. Heavy metal strapping plus inside braces supported the boxes. Each box had approximately $144 \mathrm{cu}$. ft. displacement, weighed from 700 to 800 lbs. empty and had a total gross weight, when filled, from 5,000 to 6,600 Ibs., depending on the contents. Only one class of waste was placed in a box. Readings were taken before and after filling and all boxes marked on the outside with metal numbers. Material was classified as metal, combustible and non-combustible-non-metal.

28. Shipments were made via (?) P-69, etc. Seventy-one (71) of these boxes were shipped between August 1946 and November 1947. Since 
then Oak Ridge has requested us to limit the gross weight of any one box to 1,000 lbs. As a result, boxes are now approximately $2 \%^{\prime}$ or $3^{\prime}$ square $\times 3^{\prime}$ to $10^{\prime}$ long, depending on type of contents.

29. The total number of pits used to date at Plot M number 94. This represents approximately $22,000 \mathrm{cu}$. ft. pit displacement of which an estimated $6,000 \mathrm{cu}$. ft. was used for back filling.

30. Total cu. ft. displacement of boxes shipped to Oak Rj.dge up to November 1, 1947 is $10,224 \mathrm{cu}$. ft.

31. Materials disposed of at Plot $M$ include chemicals, rubber gloves, shoes, laboratory equipment such as dry boxes, ring stands, glassware, centrifuges, specially built apparatus etc., building materials and equipment, animals and animal excrement and any and all material beyond decontamination and which constitute a hazard to health or experiments. No attempt was made to segregate certain items in particular pits.

32. About April 1946 a radium source was lost at New Chemistry. It was thought possible to have been mixed in waste paper. A check of all waste paper handling procedure was made and a trip to the Pioneer Paper company followed. During the course of searching for the source, contaminated paper was found in certain bales. The following readings cover a minor part of the incident on April 22, 1946:

Large sheet of absorbent paper

$650 \mathrm{mr} / \mathrm{hr}$ at $3 " \mathrm{~s} ; 26 \mathrm{mr} / \mathrm{hr}$ at 3 " $\mathrm{H}$;

Small sheet of absorbent paper 5000 alpha $\mathrm{d} / \mathrm{m}$ $6 \mathrm{mr} / \mathrm{hr}$ at $3 " \mathrm{~s}$; 20,000 alpha $\mathrm{d} / \mathrm{m}$

Lusteroid tube containing Kleenex Kleenex

Kleenex

Kleenex

$26 \mathrm{mr} / \mathrm{hr}$ at $3 " \mathrm{~s}$;

$62 \mathrm{mr} / \mathrm{hr}$ at 3 " $\mathrm{s}$;

$34 \mathrm{mr} / \mathrm{hr}$ at 3 " $\mathrm{s}$;

$13 \mathrm{mr} / \mathrm{hr}$ at 3 " $\mathrm{s}$;

33. On May 17 th $1946 \mathrm{Dr}$. F. Daniels wrote the following letter to Dr. J.J. Nickson.

"I have your memo of May 11th regarding research on the waste disposal of contaminated paper. In my opinion the disposal of radioactive materials from research laboratories and piles constitutes one of the greatest and most important problems in the development of nuclear research in this country. Accordingly I do not hesitate to authorize you to carry out such programs of research as you see fit for solving this problem. You suggest two or four persons with the necessary background and suitable equipment. If you have such men available you can perhaps transfer them from other work. In case you do not I am sure it would be in order for you to attempt to employ new men if you can find proper qualified ones and I suggest that you choose men who would be able to carry on other programs which you have in mind after this problem has been solved.

I am glad to authorize you to proceed with the program along the lines which you suggest." 
34. As a result the waste paper problem was reviewed and following a. discussion with Dr. J.J. Nickson, Mr. J.E. Rose, and others it was decided that all laboratory waste paper (not that however placed in active waste cans) should be processed by burning.

(Incidentally the above radium source was located about two minutes before it would have been permanently lost on its way to the paper reprocessing plant.) An incinerator of acceptable design was procured and arrangements made to burn all waste paper at Plot M. For certain reasons this procedure was ordered held up pending other developments. A second contaminated paper incident in 1947 made it definitely clear that something had to be done to control ALL waste paper. It was decided by a disposal committee that it would be feasible to bale all paper and ship it to oak Ridge. The Safety Department thereupon procured a baler from the Economy Paper Balex Company. Due to the limited space at our intown sites it was decided to bale all paper at Plot $M$. The requirements set forth by the Safety Department encompassed a one story building approximately $25^{\prime} \times 40^{\prime}$ with suitable doors and windows and to be placed in the burial area at Plot $M$. Upon completion of plans, important developments of Site $D$ materialized and a directive was received to hold up the above construction. However, shortly after the 2nd paper incident, all waste paper was no longer sold for reprocessing but taken to the cicy dump and burned. Checkups on the hauler showed that the hauling contractor did burn the paper as per orders.

35. In November 1947 Plot $M$ was enlarged by approximately $50^{\prime} \times 125^{\prime}$.

36. The waste disposal problem has been under study by this department since early 1944. Due to the lack of established precedent each new step in the handling of active waste was a matter of experiment. Containers were designed time and again. Methods of handling "hot" substances were scrutinized for improvement. At this time the initial step is being worked on in Ryerson shop, which design, in our estimation, satisfies all safety requirements. This particular item is a special active waste receptacle which minimizes contamination of the lid during filling and emptying operations, permits decontamination of the interior and along with a second special pickup container prevents crosscontamination from a replacement can basis.

C.A. Young

Safety Engineer

$C A Y: m l j$

CC: (1) W.H.Z.

(1) J.E.R.

(1) ?.?.

(1) J.H.M.

(2) $\mathrm{F}$

w/encl: 1 data sheet

1 print $A-42$

1 print $A N L-A-8$ 
DATA COVERING USE OF PLOT M

Original plot size $\left(55^{\prime} \times 100^{\prime}\right)$

Ist enlargement to $\left(90^{\prime} \times 150^{\prime}\right)$ minus $800 \mathrm{sq}$. ft.

2nd enlargement to $\left(140^{\circ} \times 150^{\circ}\right)$ (present size)

No. of pits (to date)

Total displacement of pits to date

Volume of pits used for back fili

Net volume of disposed of material

Type of material in pits --
$5500 \mathrm{sq}$. ft.

$12,700 \mathrm{sq}$. ft.

$20,200 \mathrm{sq}$. ft.

94

$22,000 \mathrm{cu}$. ft.

$6,000 \mathrm{cu} . \mathrm{ft}$.

$16,000 \mathrm{cu} . \mathrm{ft}$.

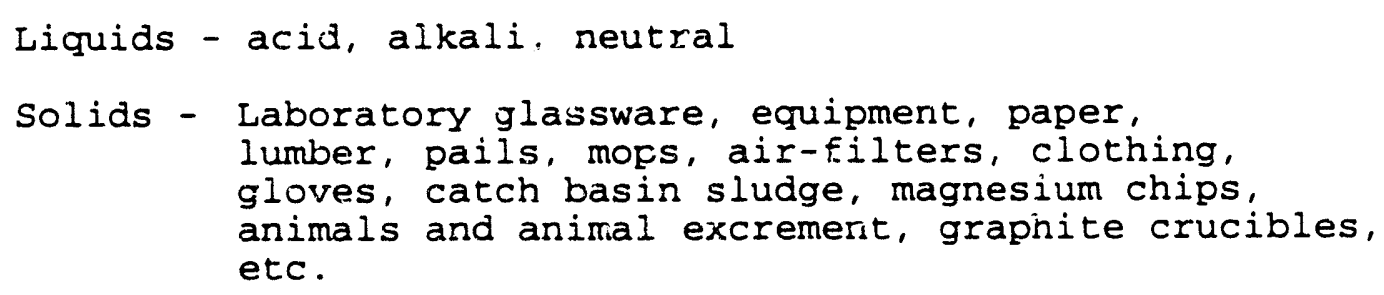

Froduct accounted for in pits (as per disposal request records) $70 \mathrm{mg}$.

Proauct unaccounted for in pits (i.e. in nondescript solutions) ? (and solids)

Liquids limited to pits

Liquids poured in pits from

Liquids retained in containers in pits

Estimated quantity of liquids in pits

Activity range

Maximum reading obtainable over pits
No. 2 to about 35

No. 2 to 6

No. 7 to 35

500 gallons

$0-600,000 \mathrm{~d} / \mathrm{m}$

0-10 R/hr.

$10 \mathrm{mr} / \mathrm{hr}$. 
APPENDIX B:

PRELIMINARY IDENTIFICATION OF APPLICABLE OR RELEVANT AND APPROPRIATE REQUIREMENTS AND TO-BE-CONSIDERED CRITERIA 


\section{APPENDIX B:}

\section{PRELIMINARY IDENTIFICATION OF APPLICABLE OR RELEVANT AND APPROPRIATE REQUIREMENTS AND TO-BE-CONSIDERED CRITERIA}

Potential contaminant-specific, action-specific, and location-specific applicable or relevant and appropriate requirements (ARARs), and to-be-considered (TBC) requirements (including DOE Orders) are identified and evaluated in this appendix. The preliminary ARAR and TBC determinations for these requirements are also indicated below. 


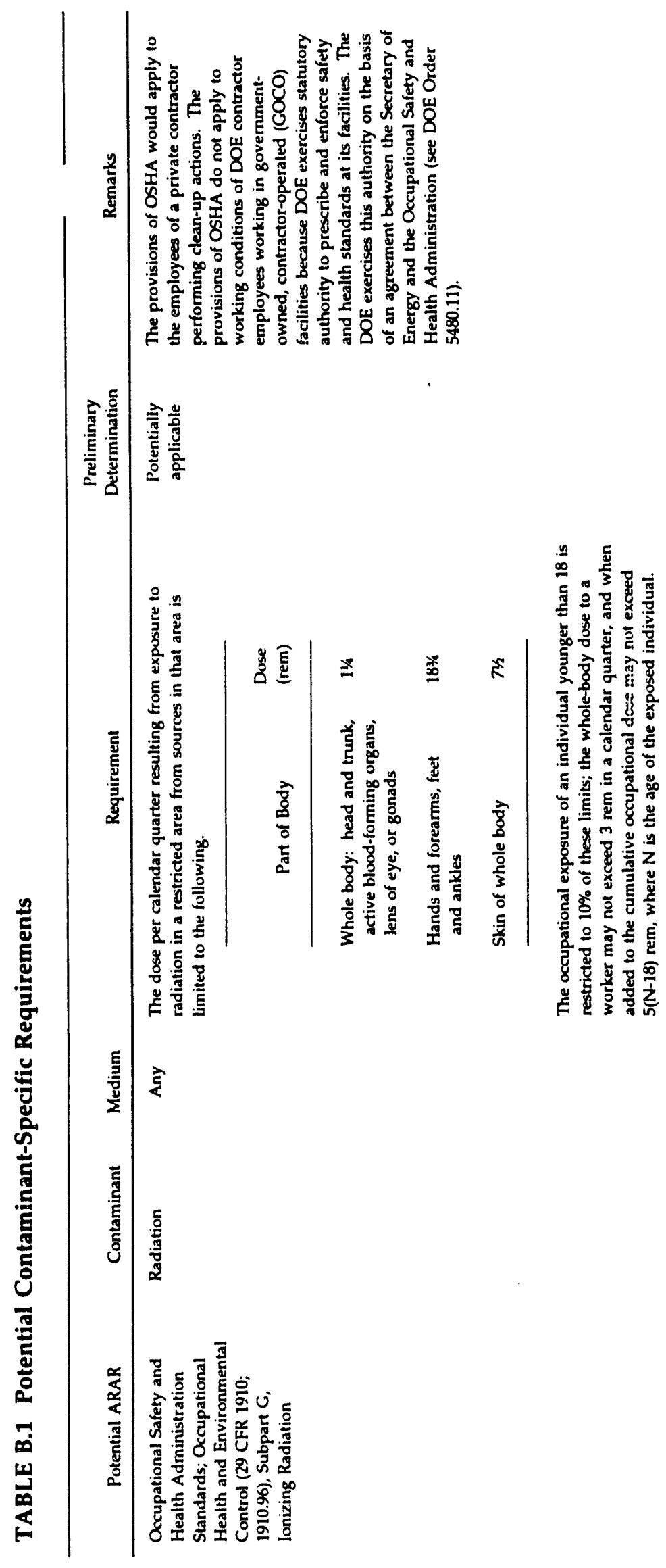




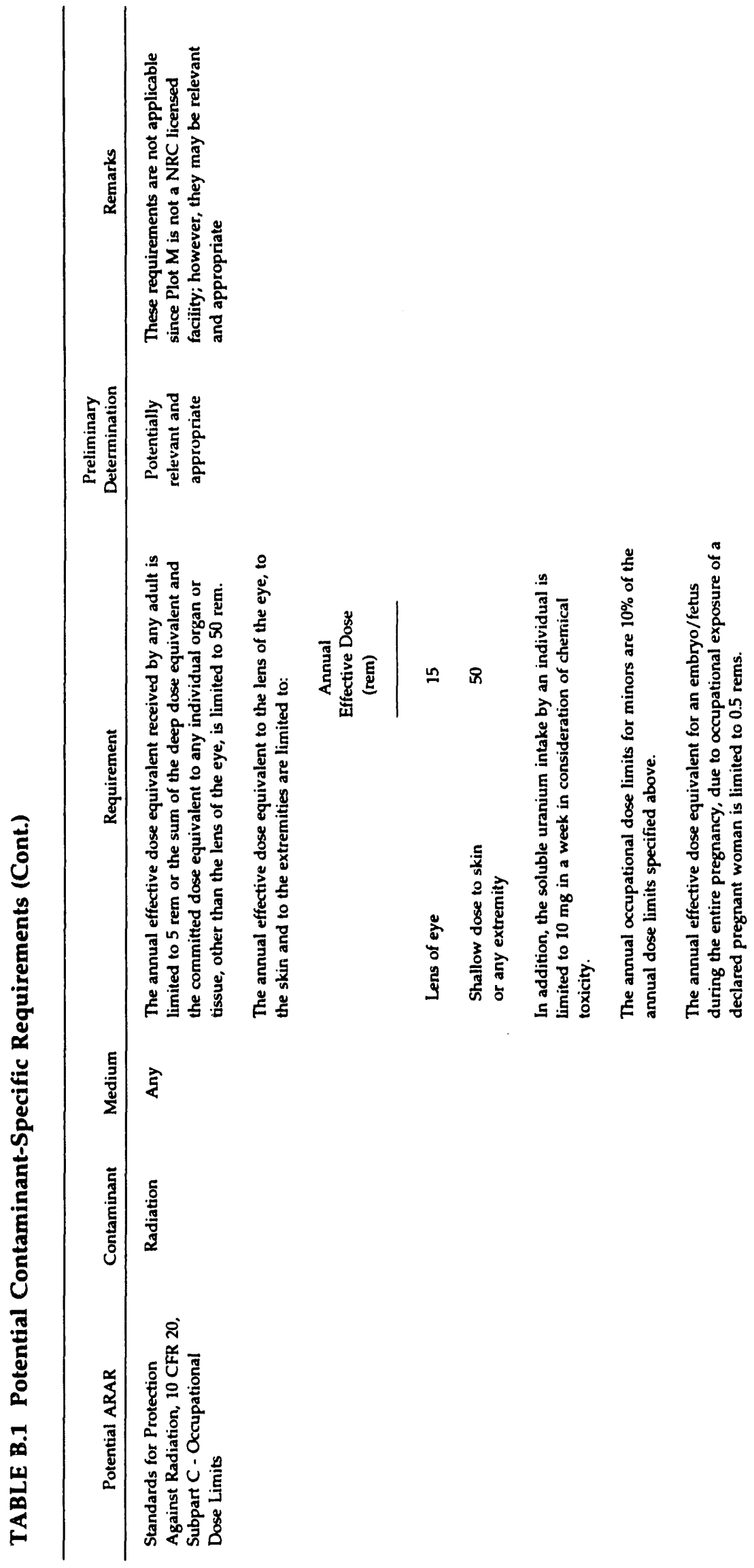




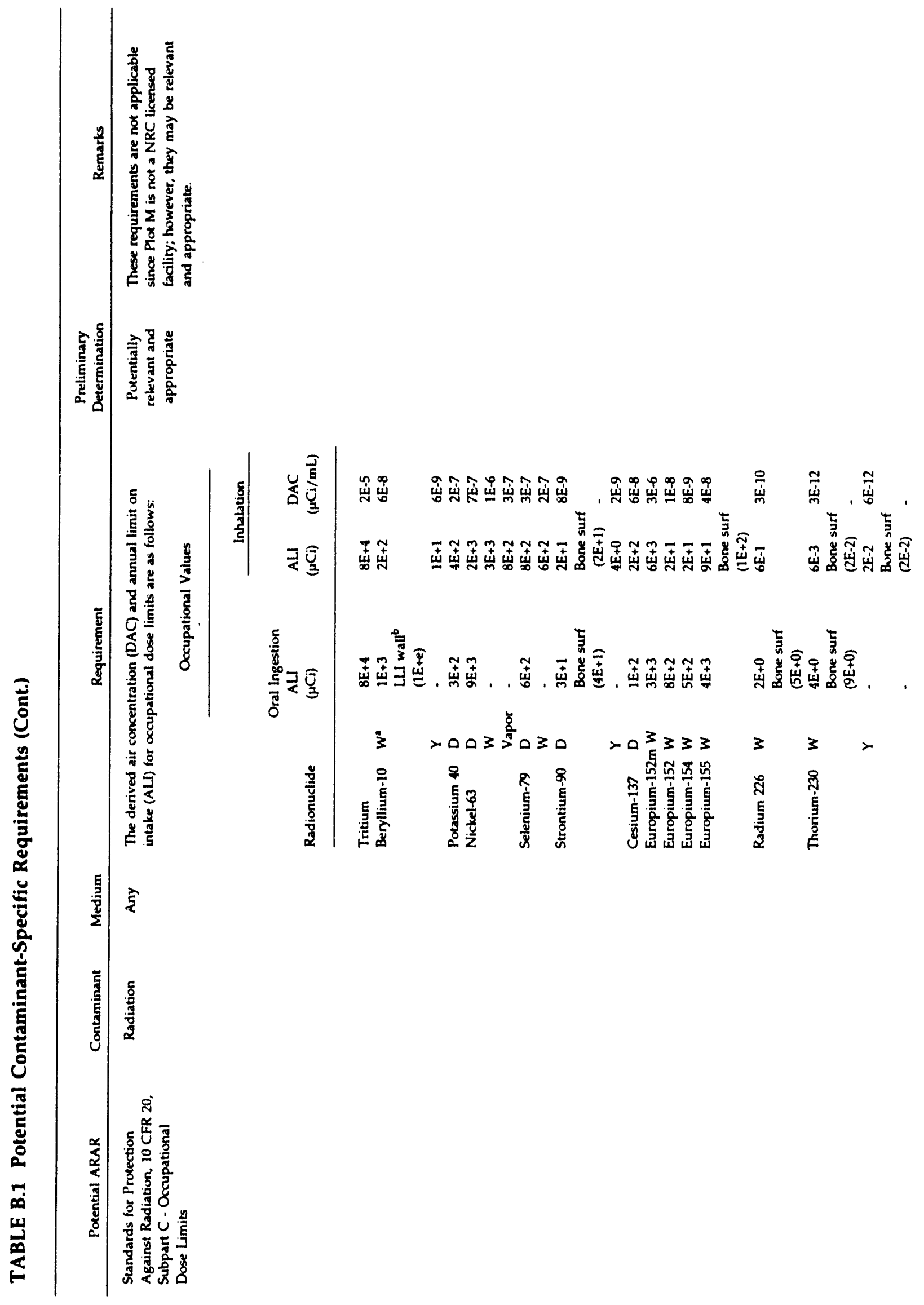




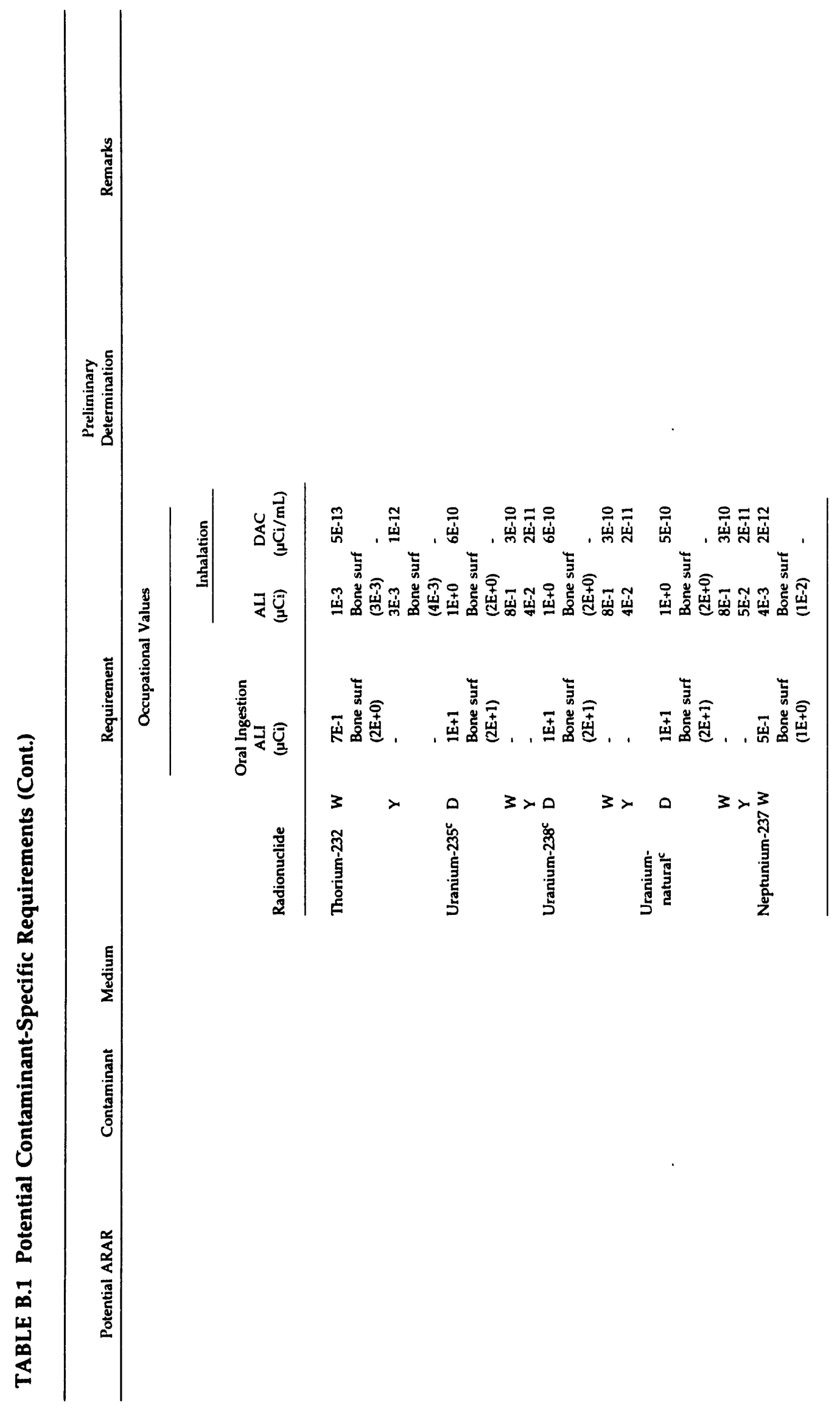




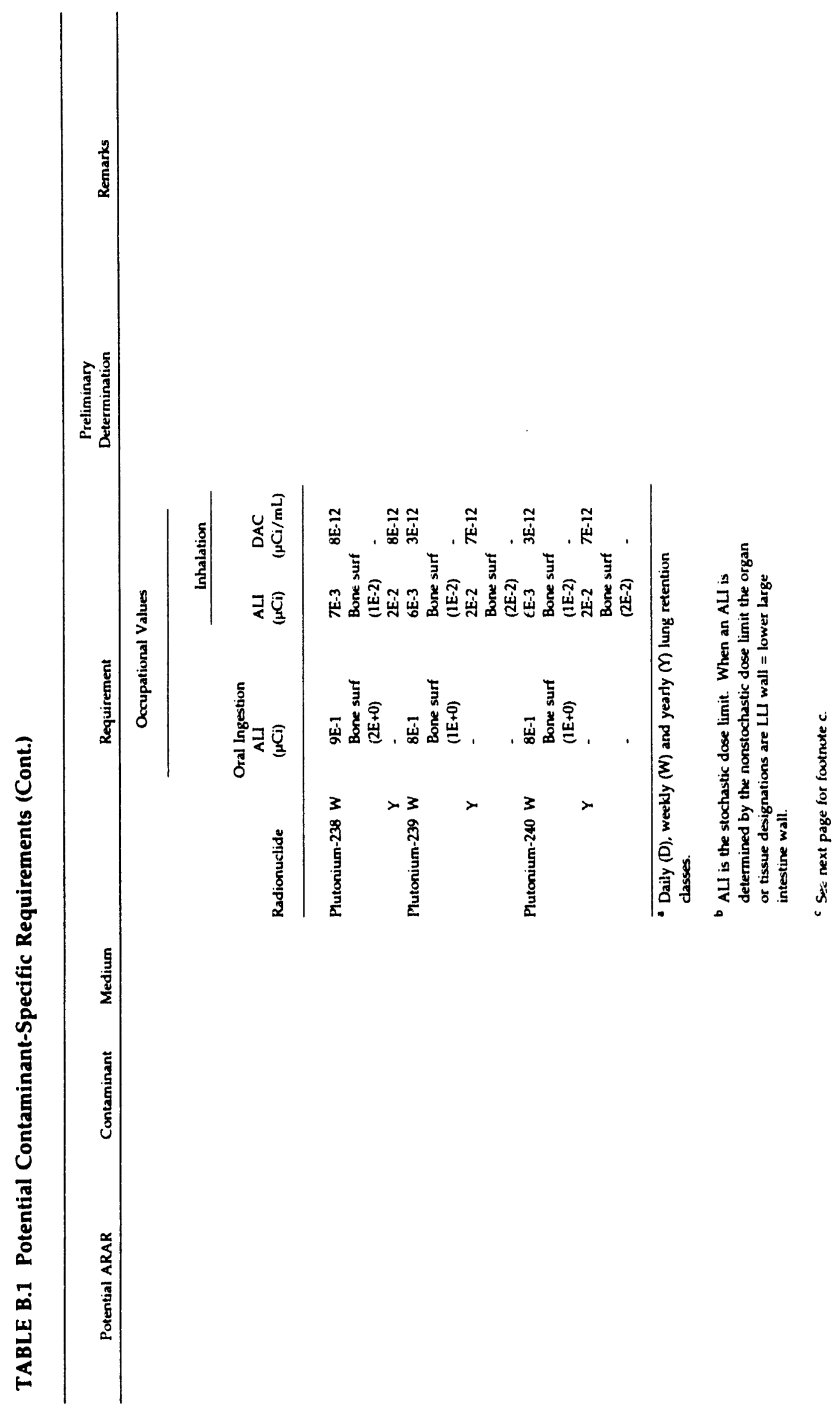




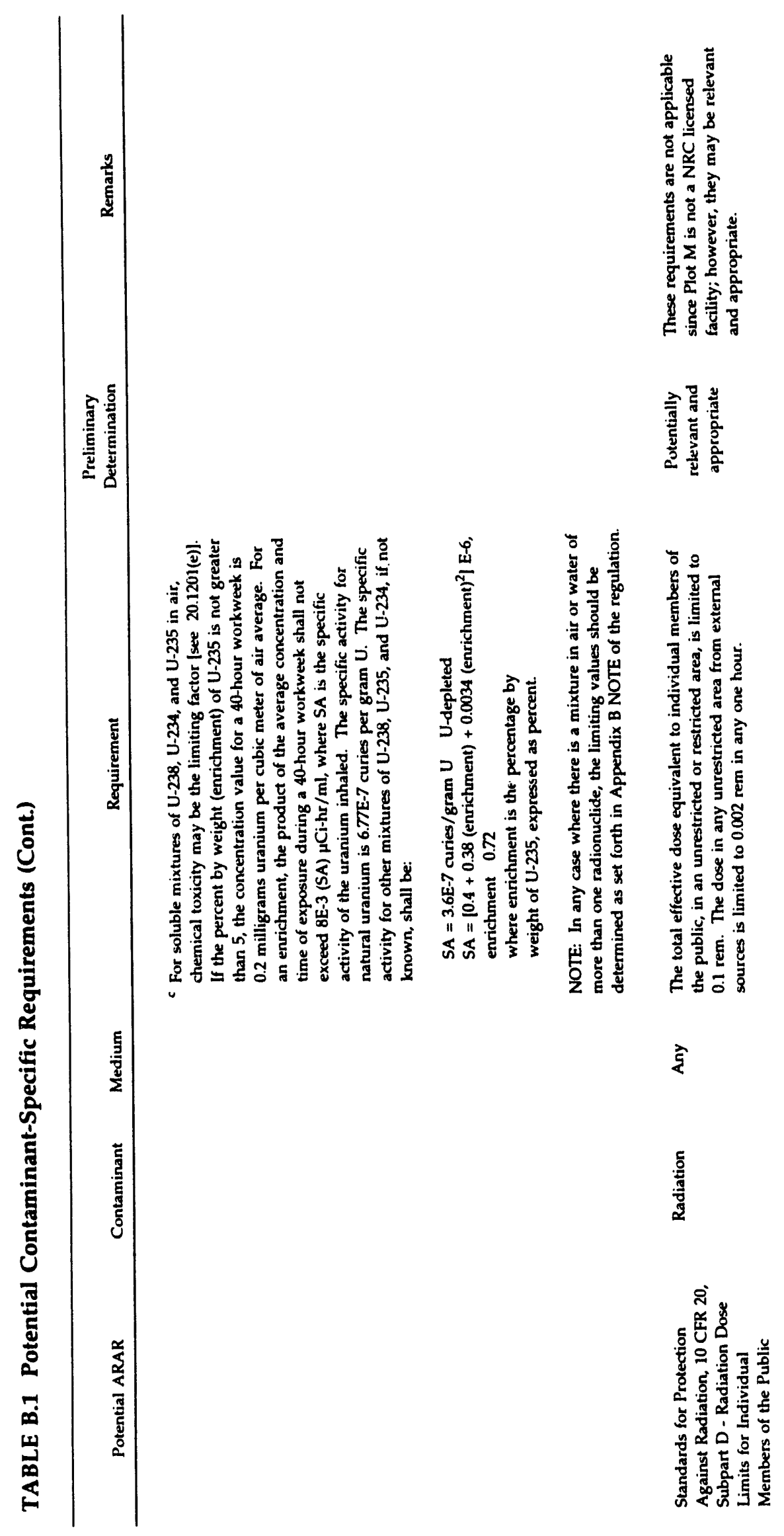




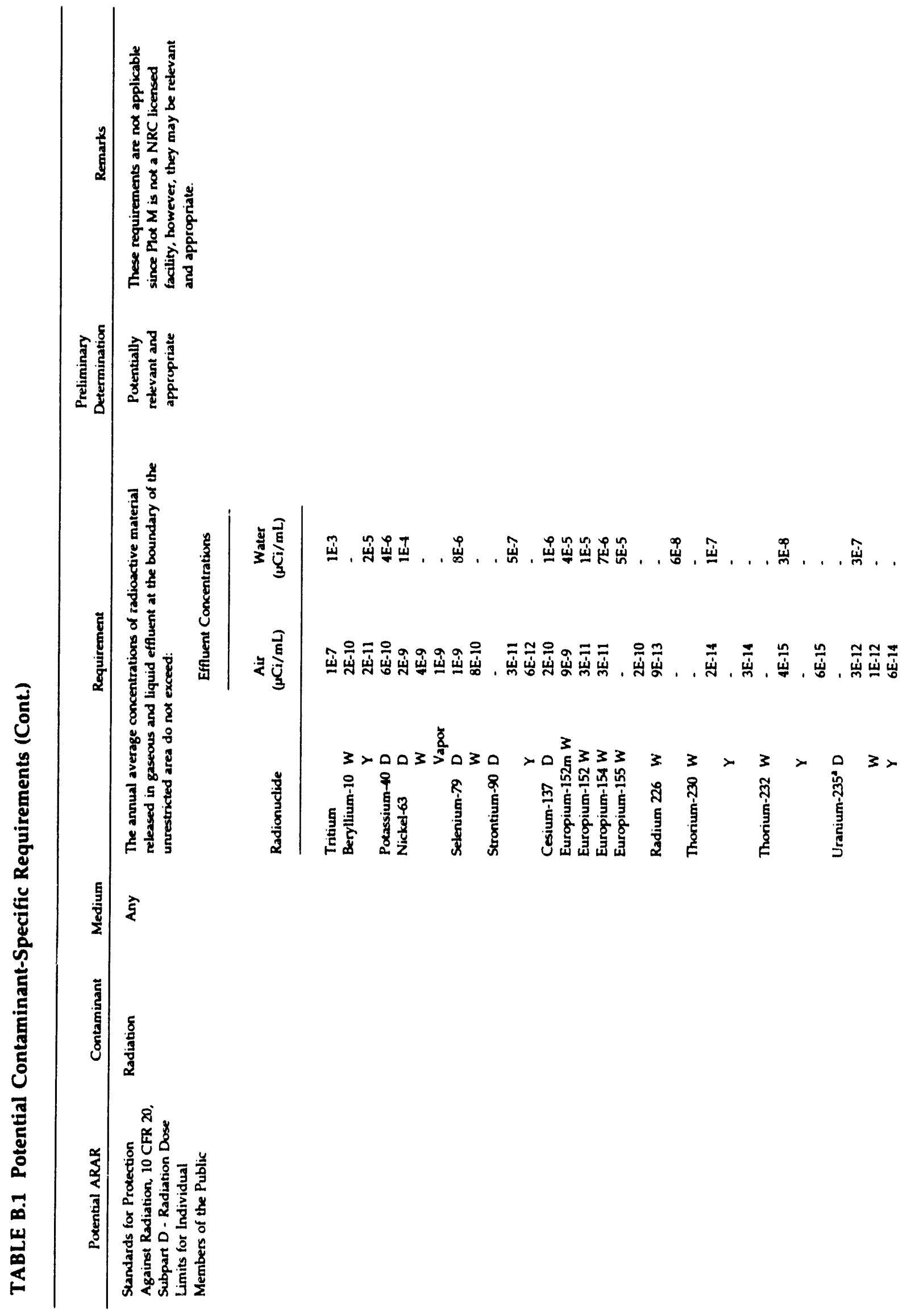




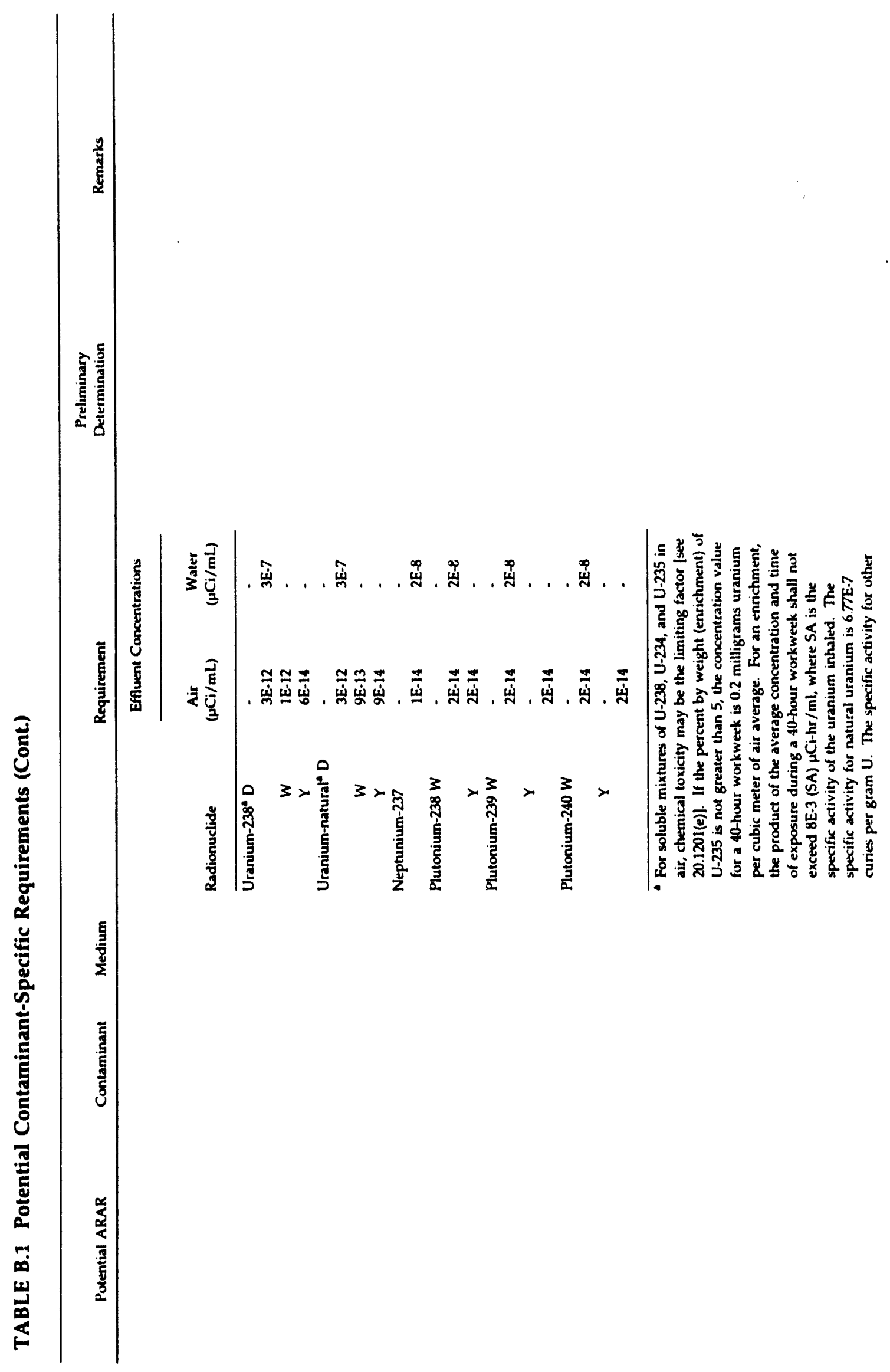




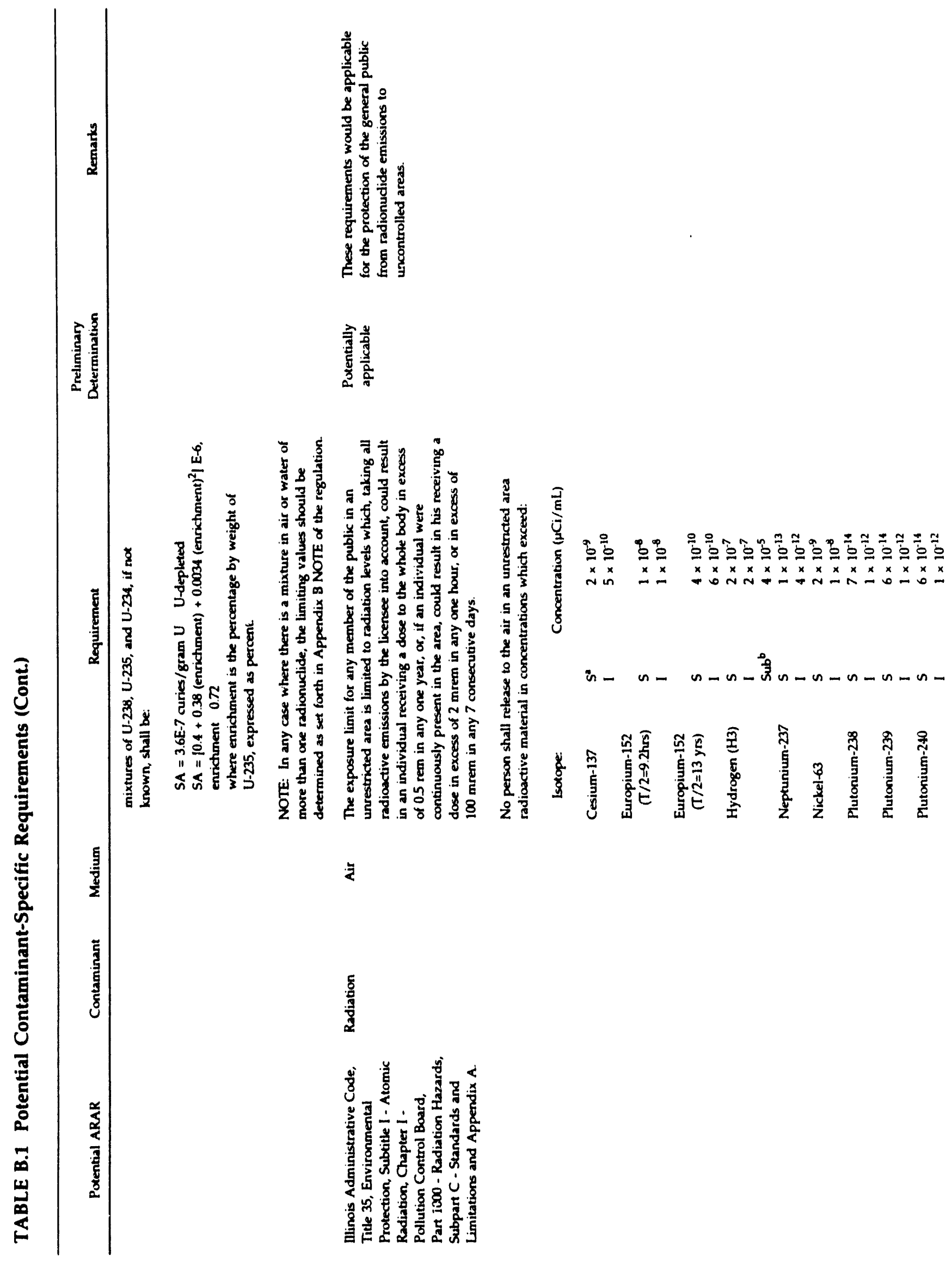




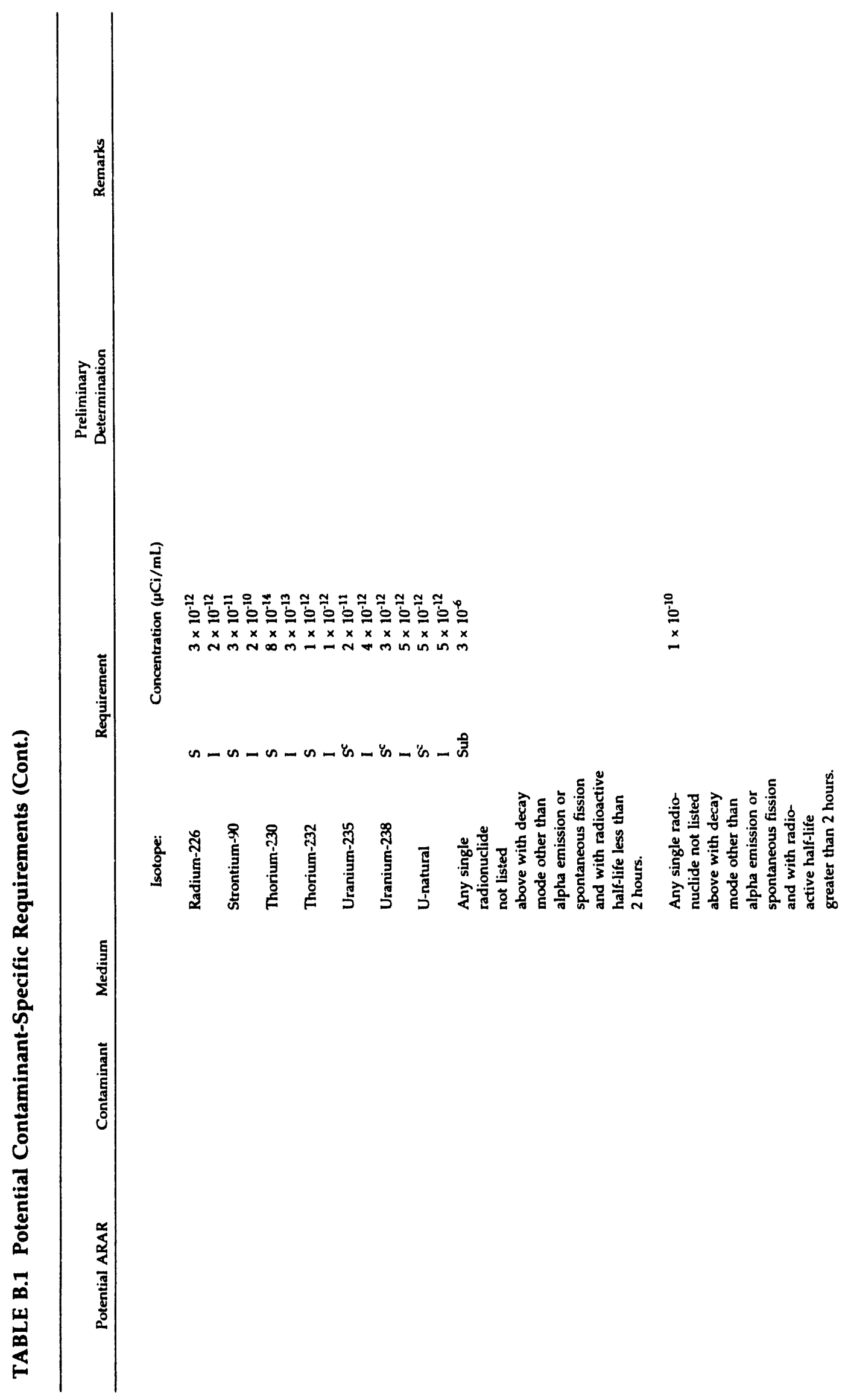




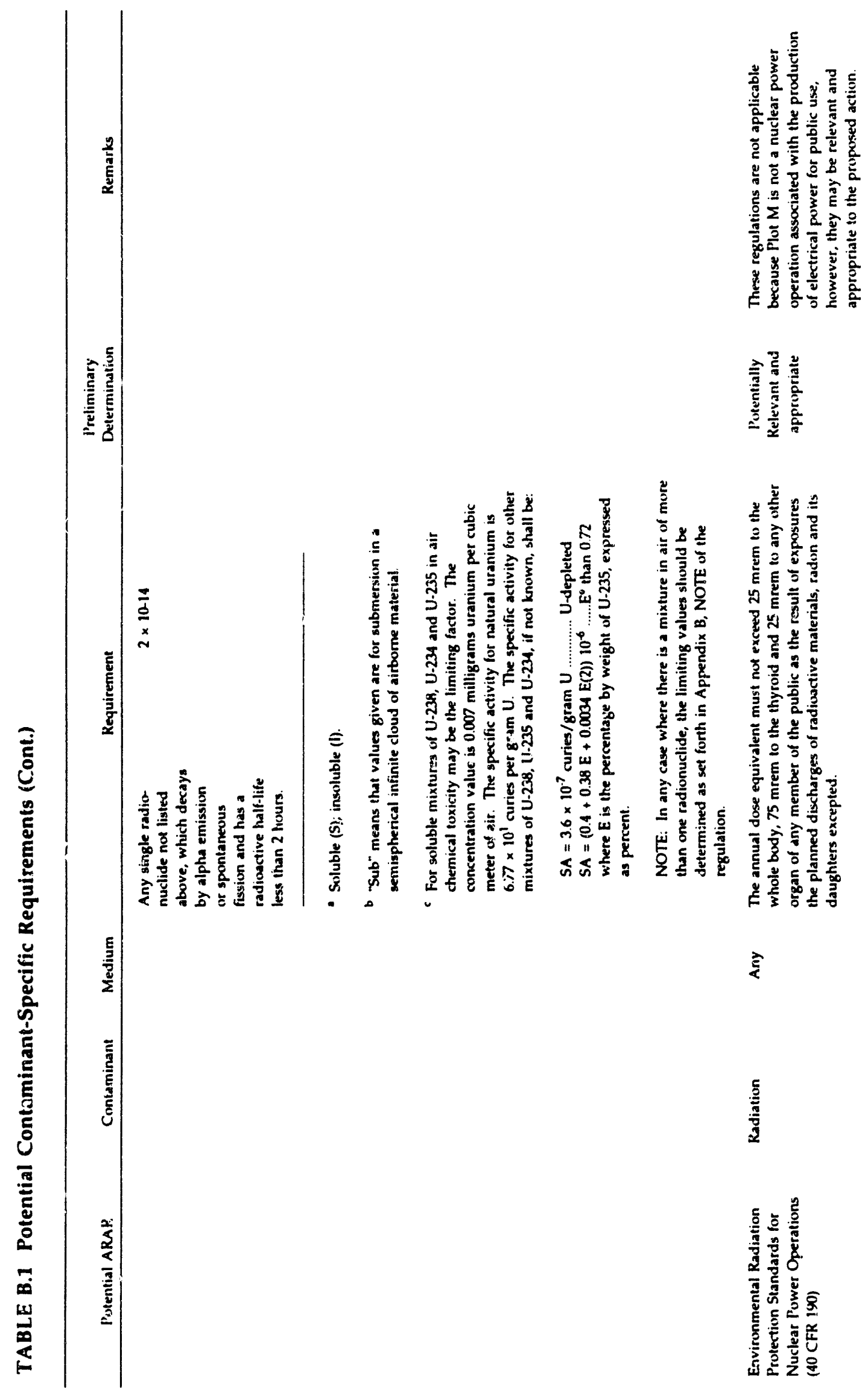



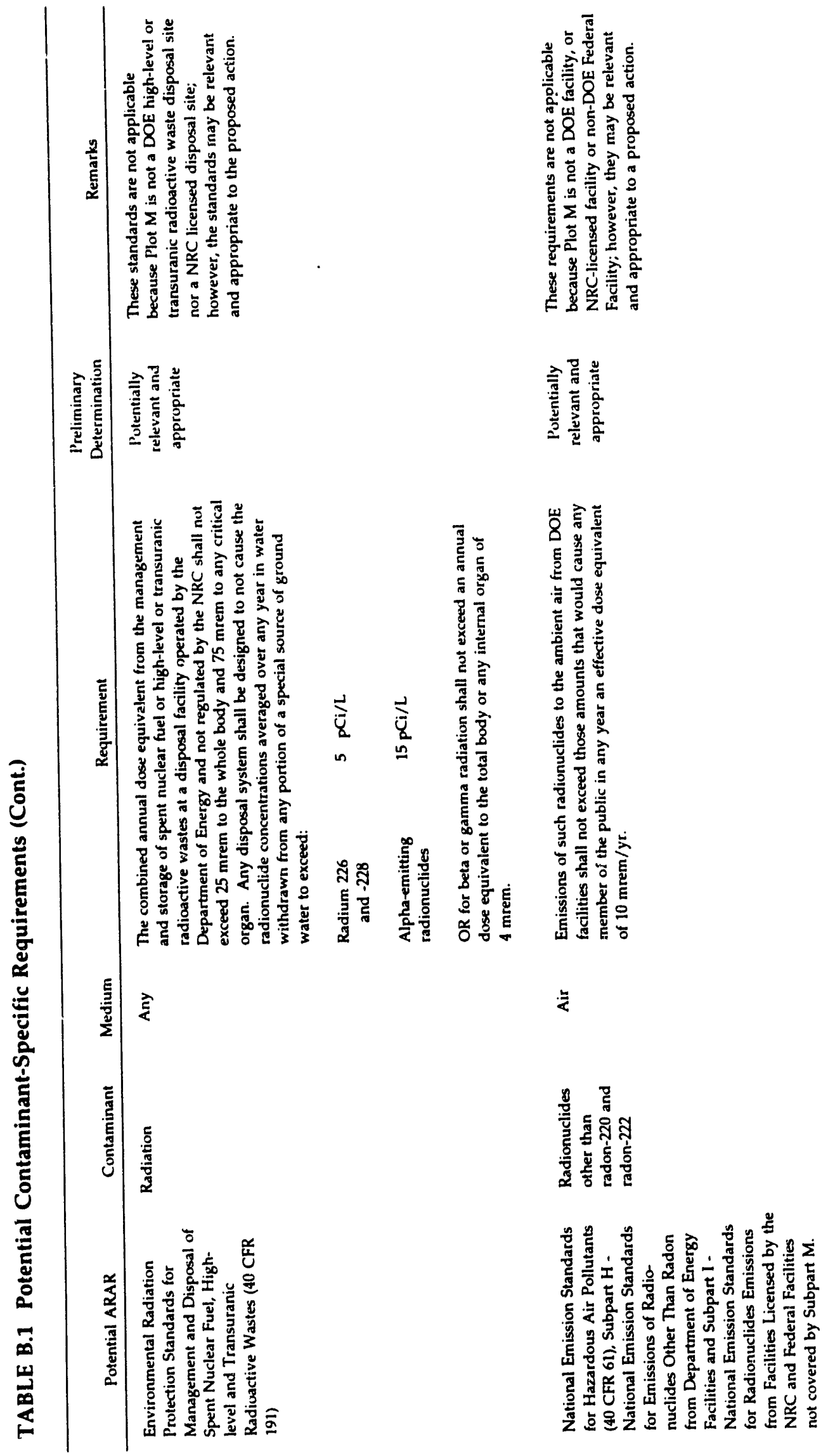


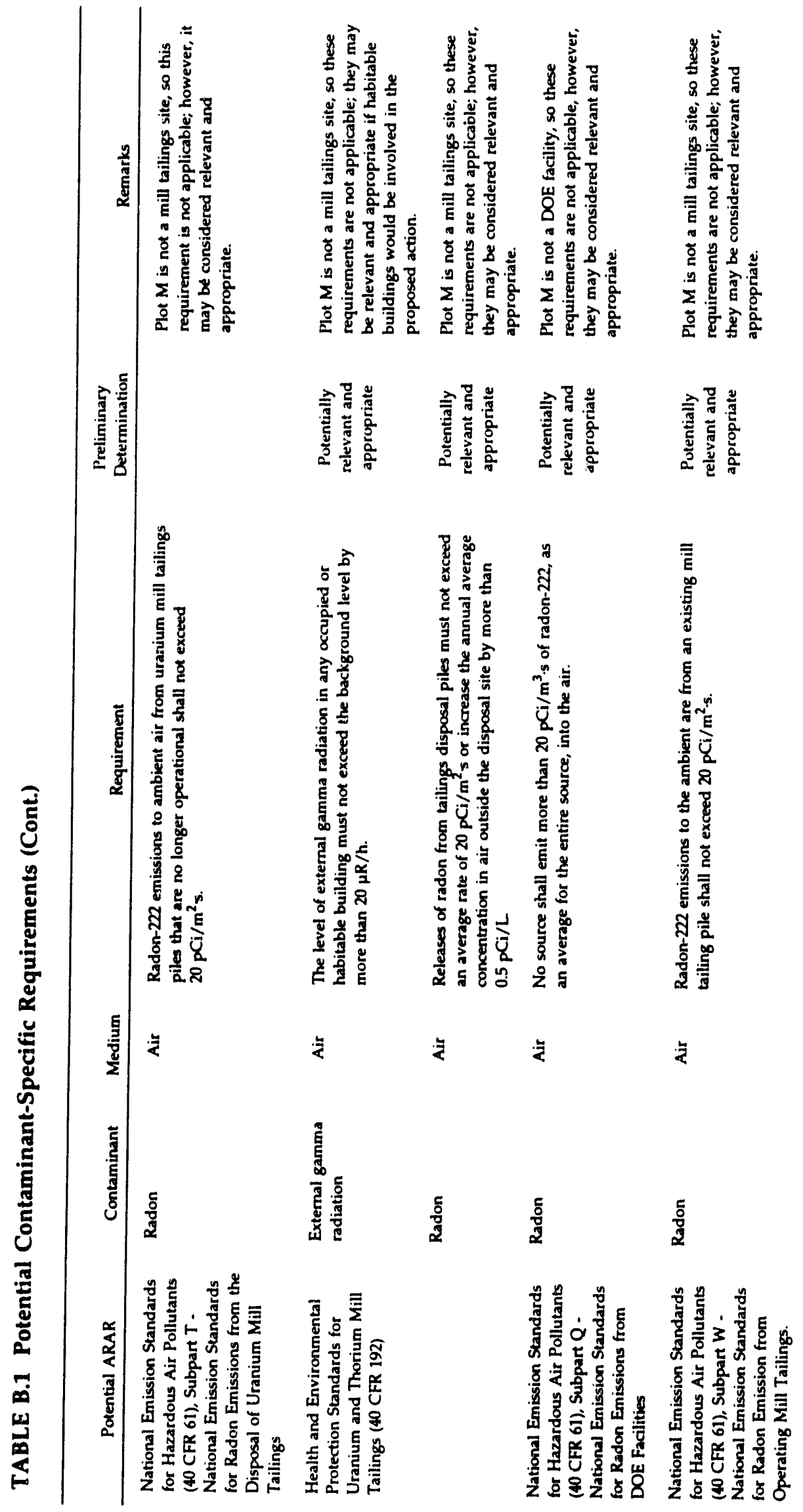




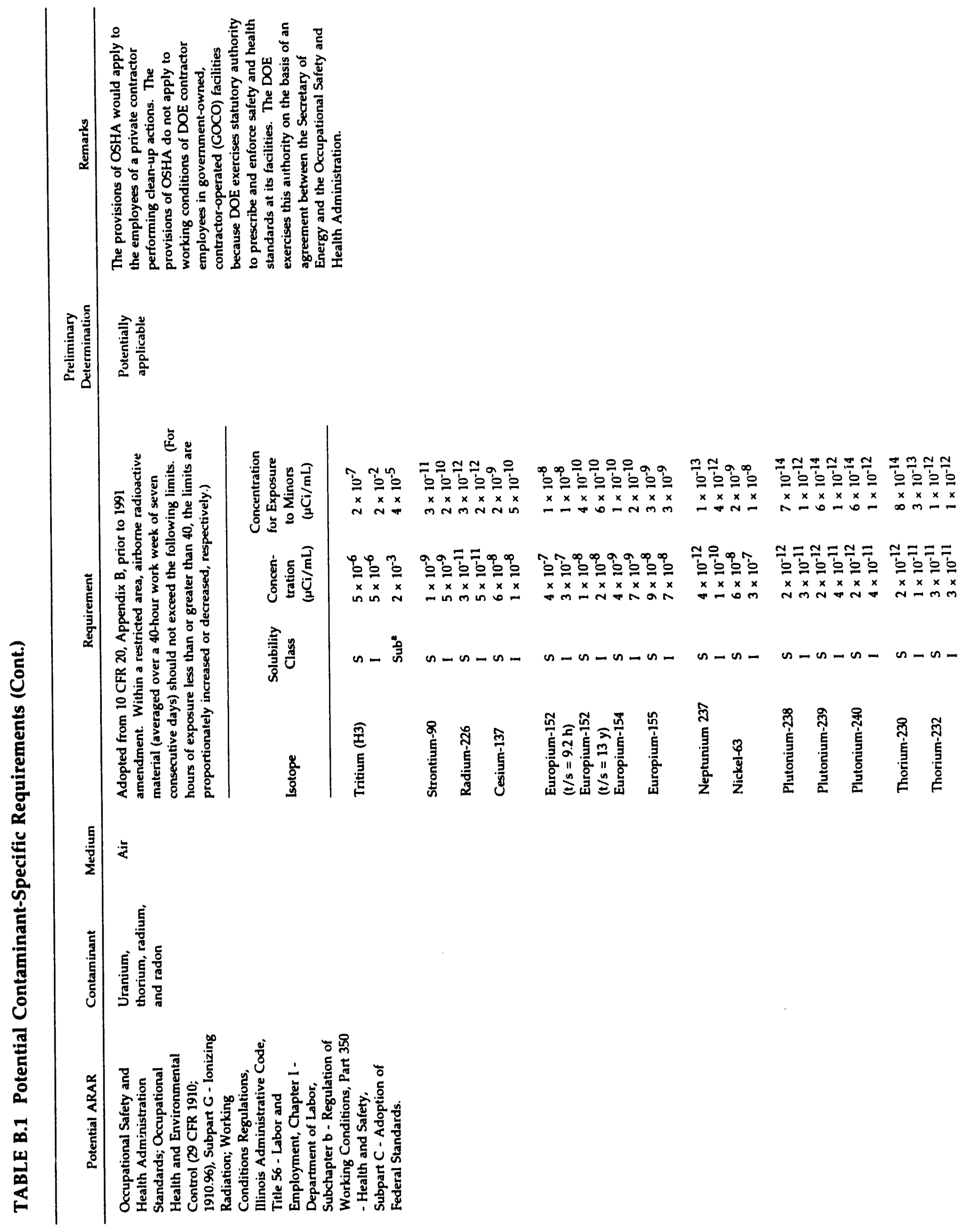




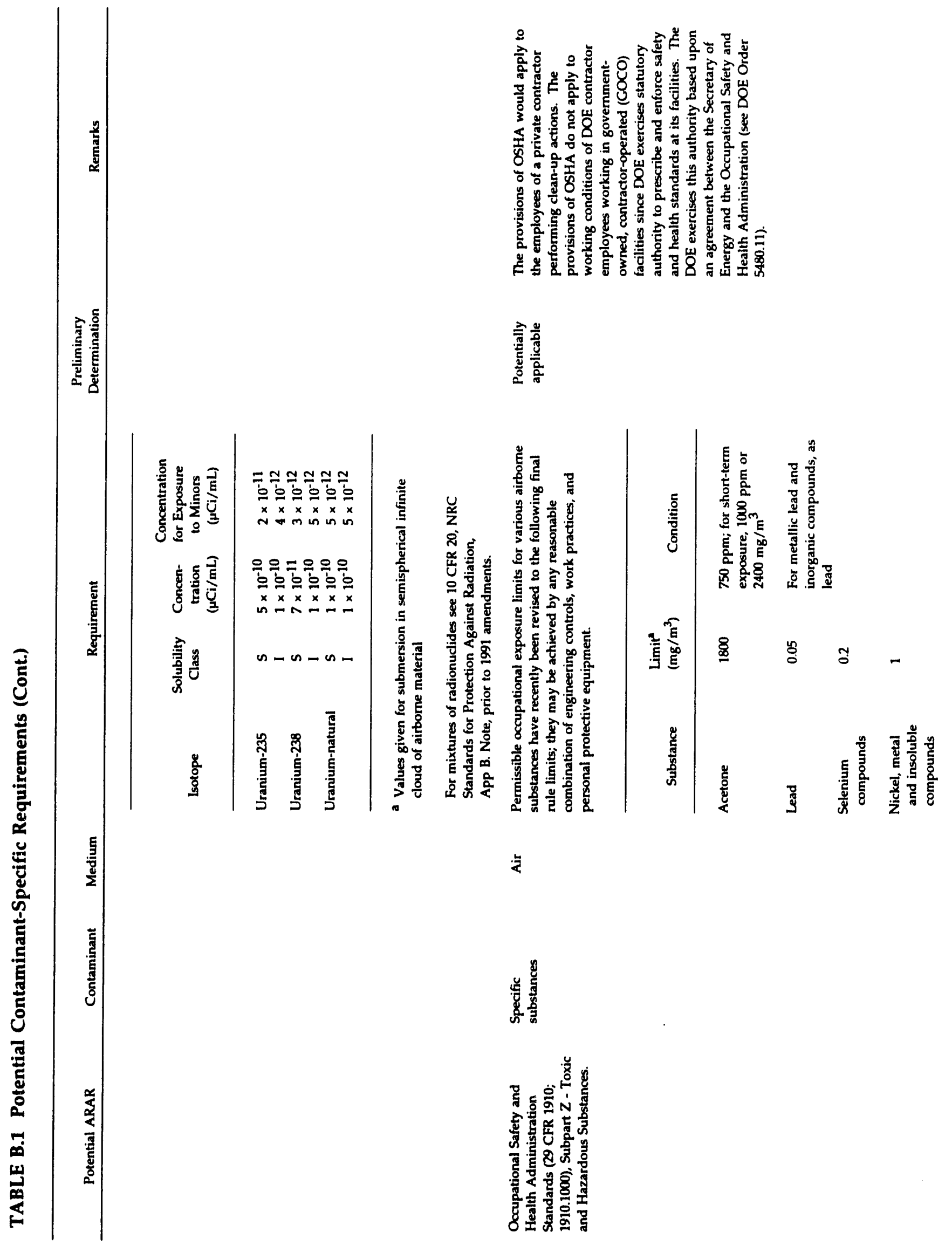




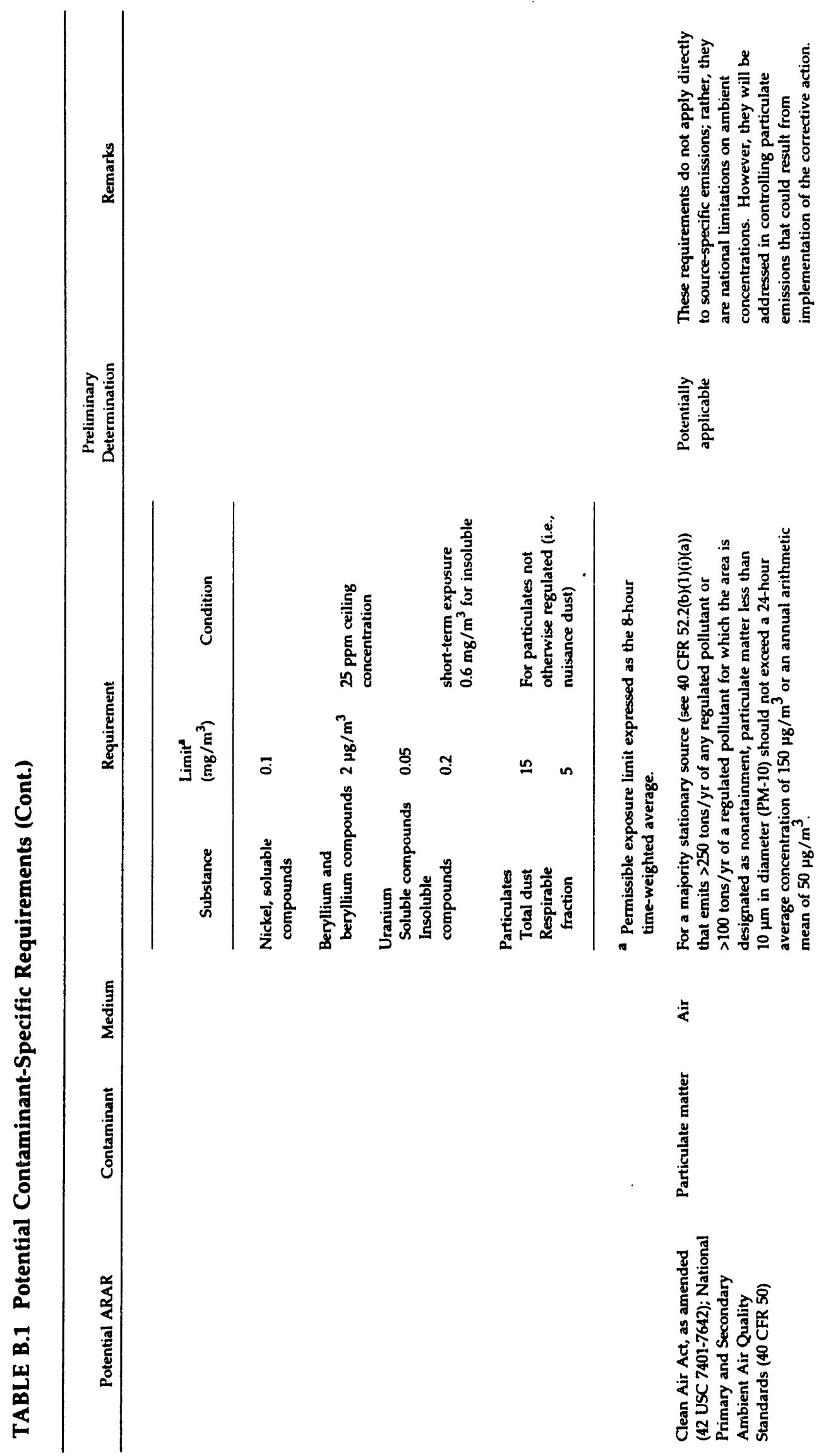




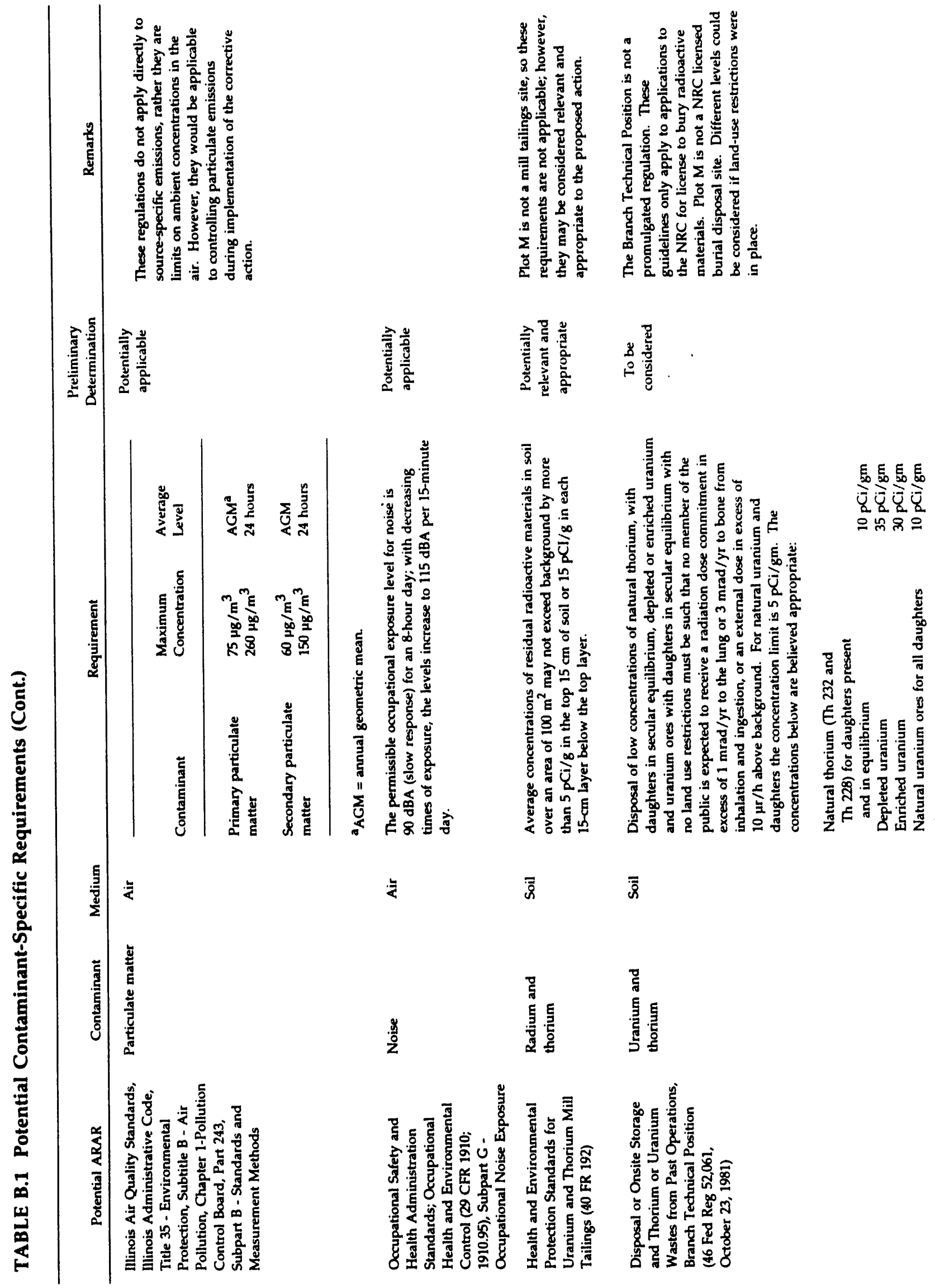




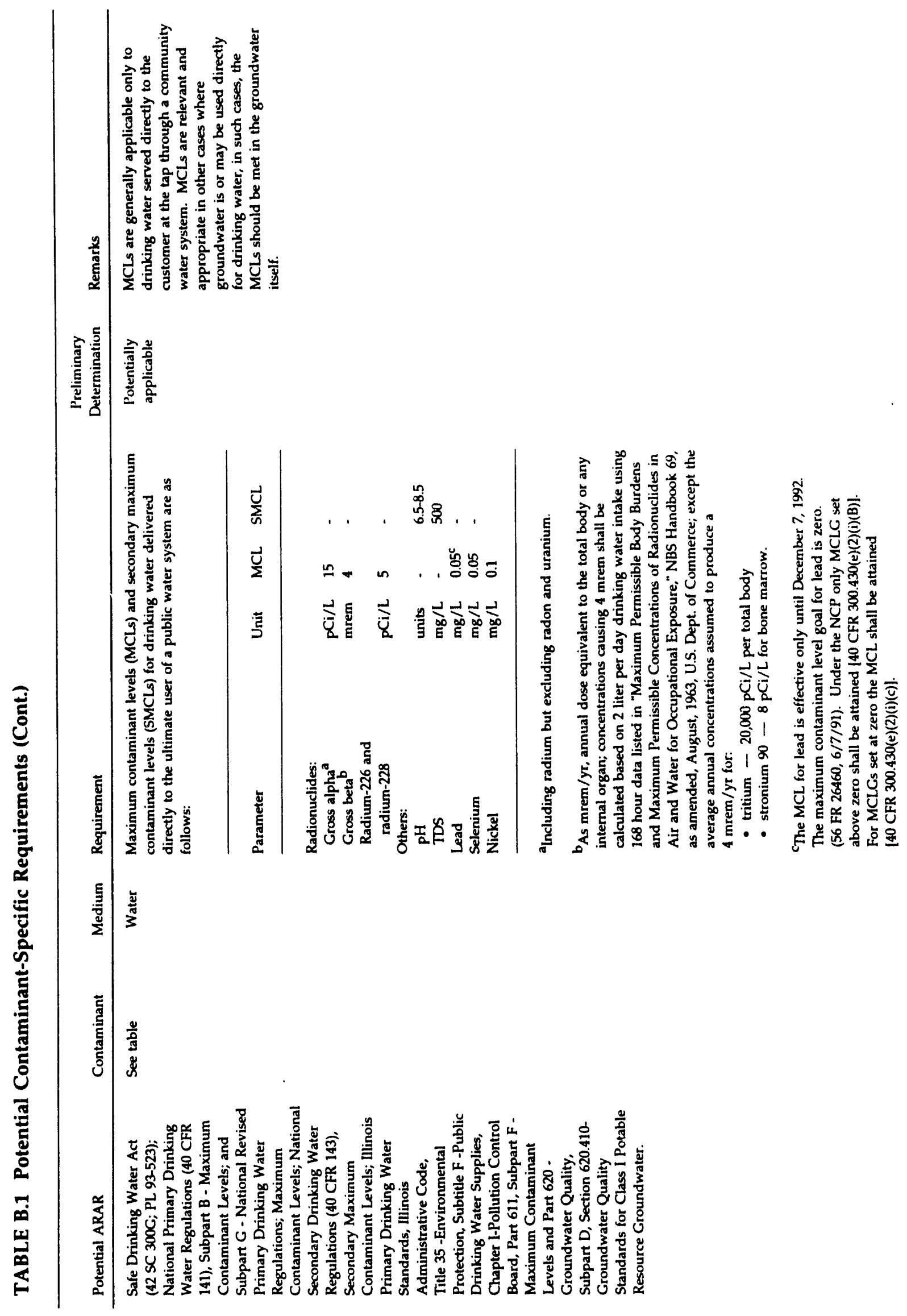




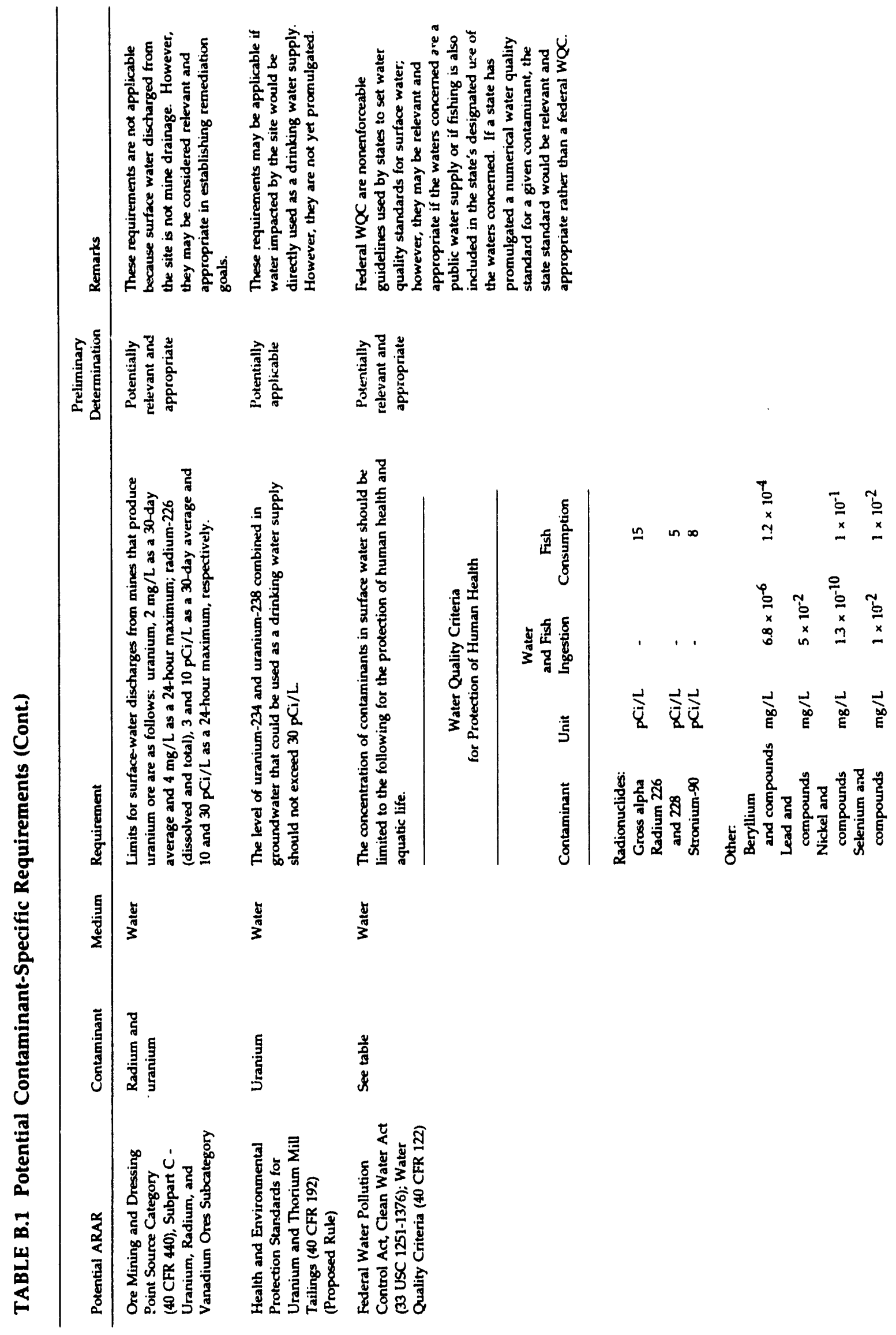




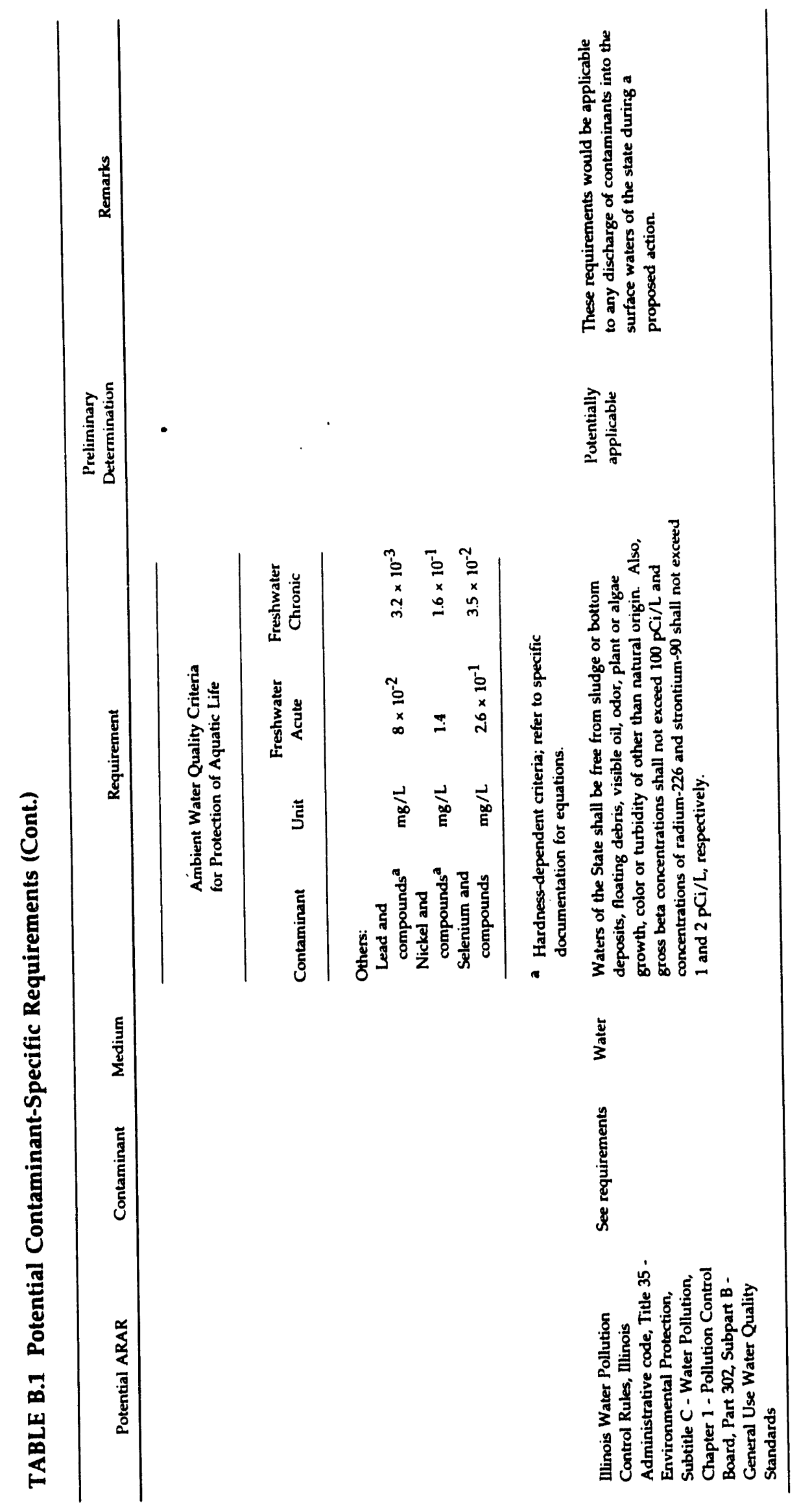




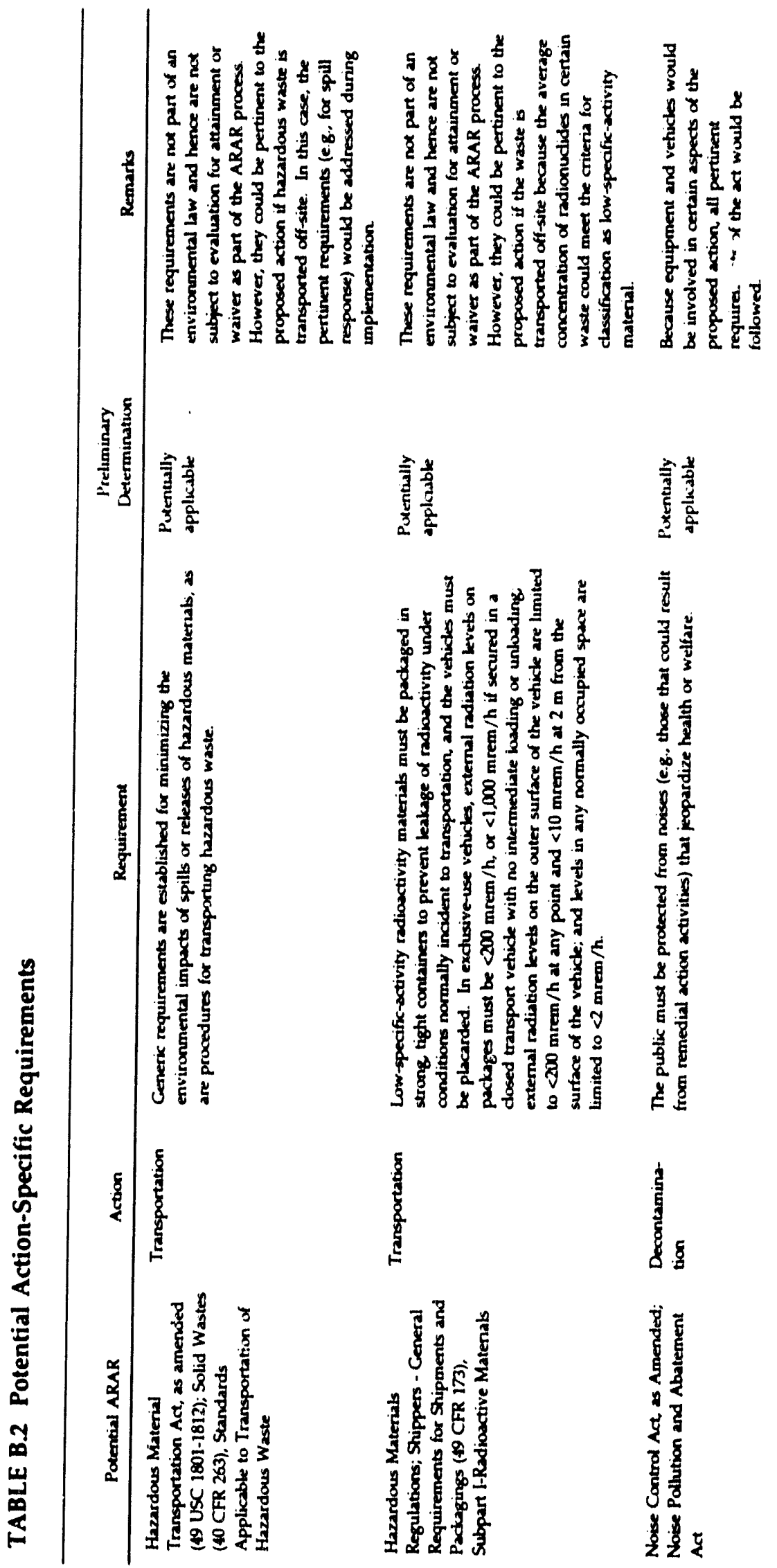




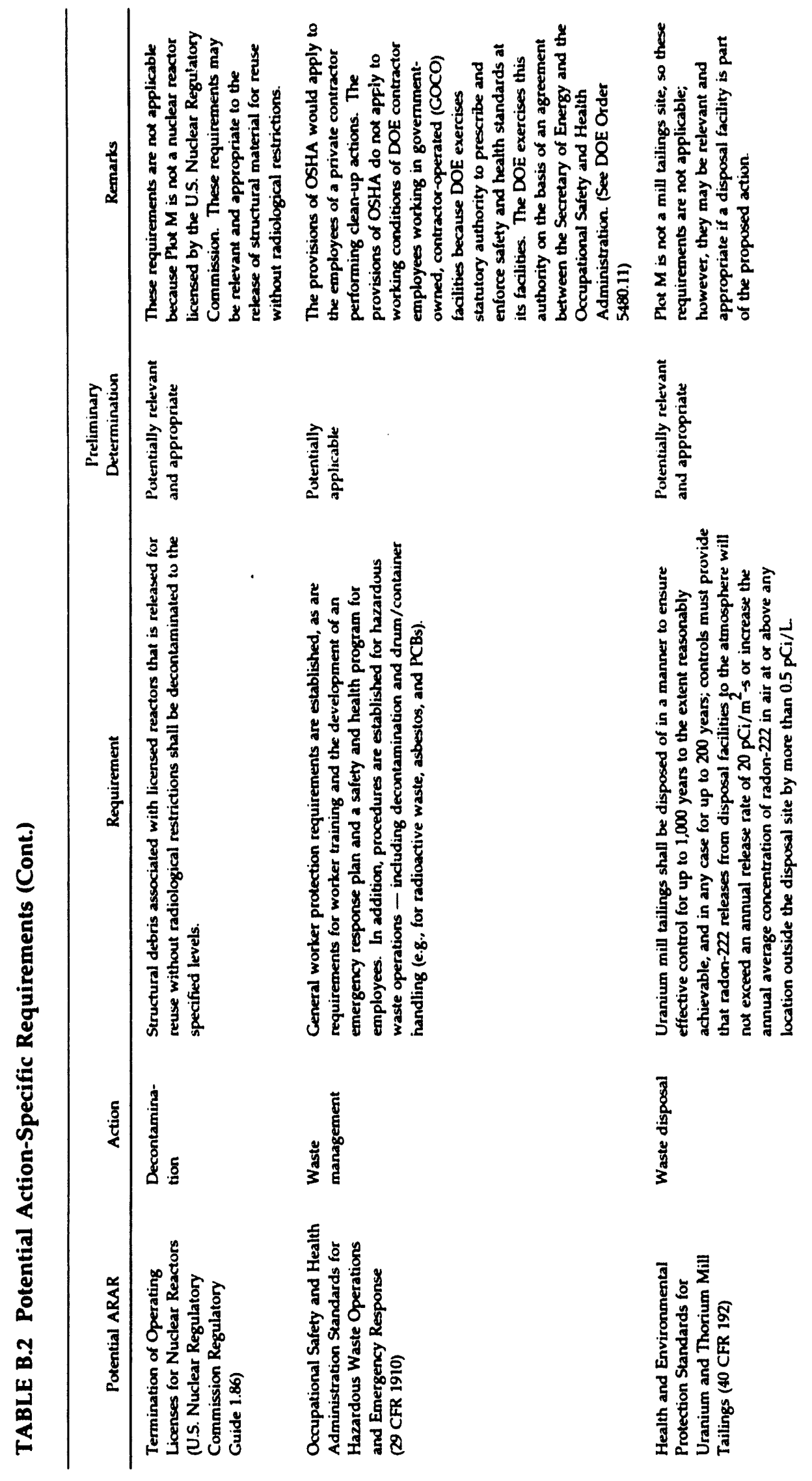




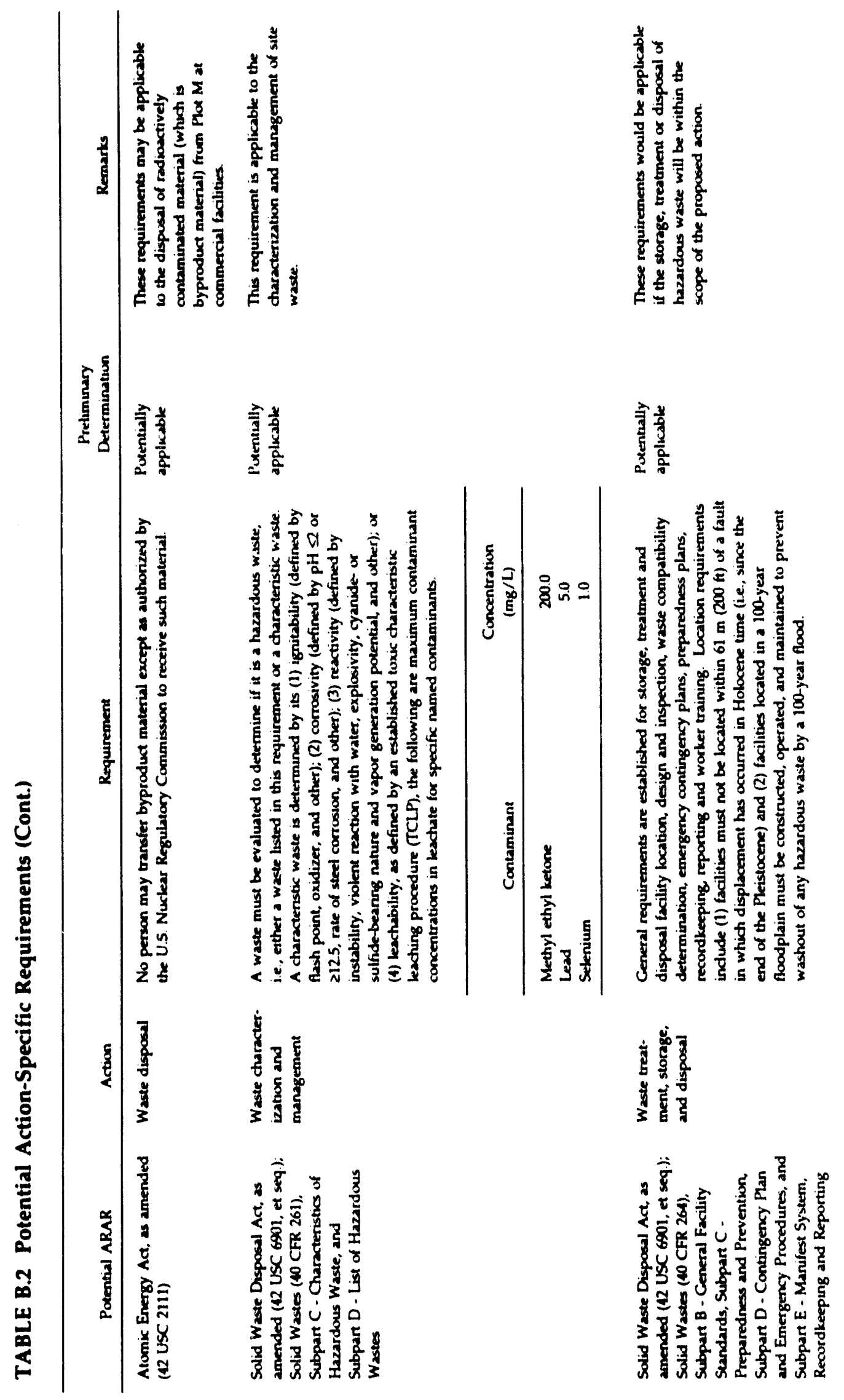




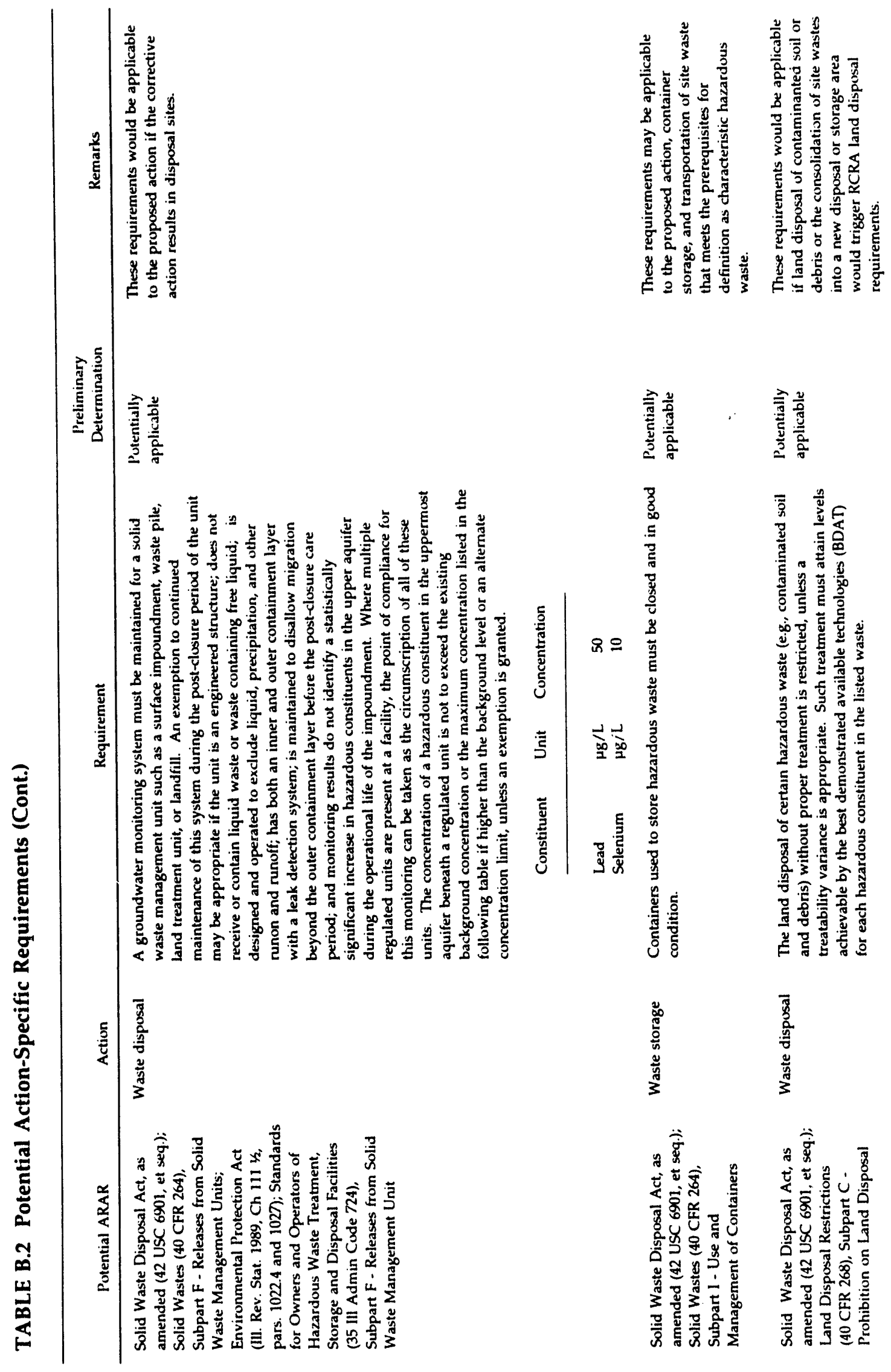




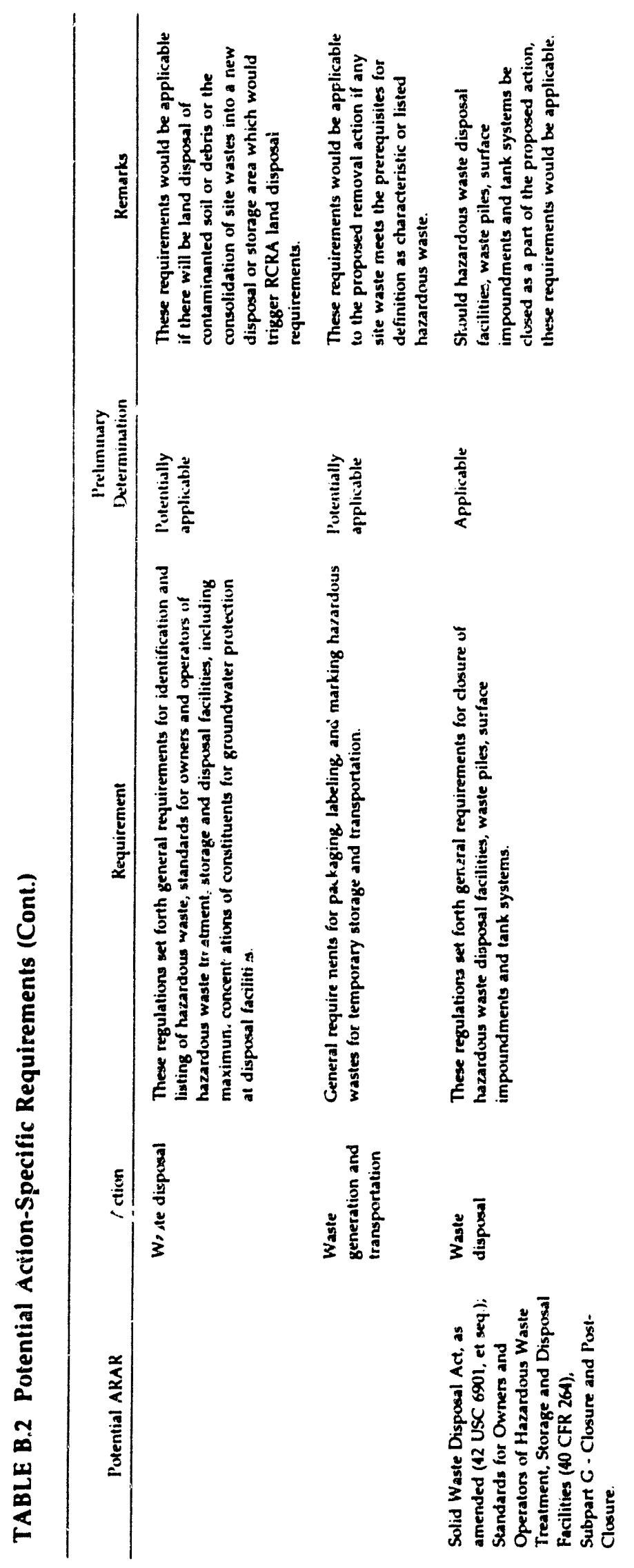




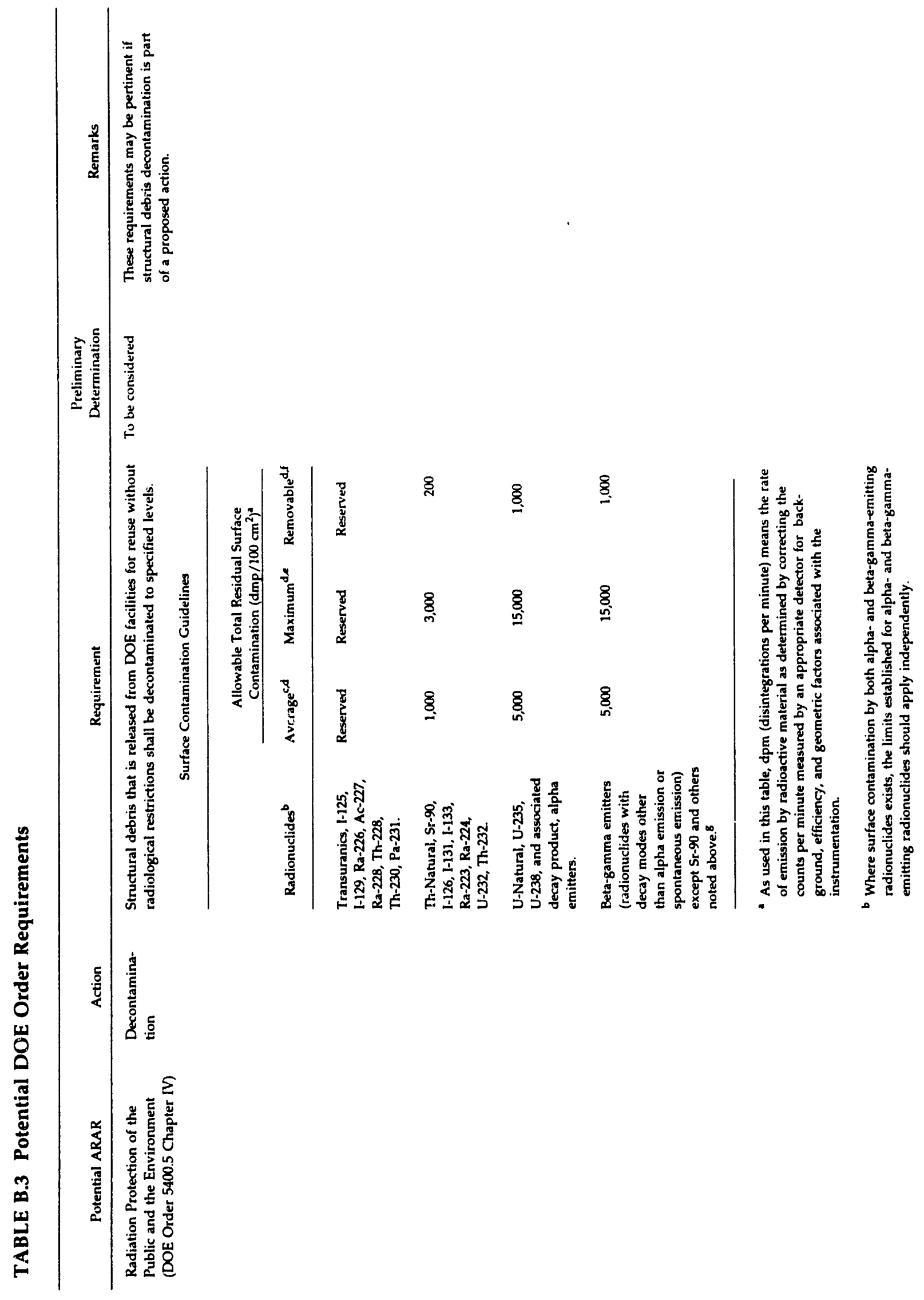




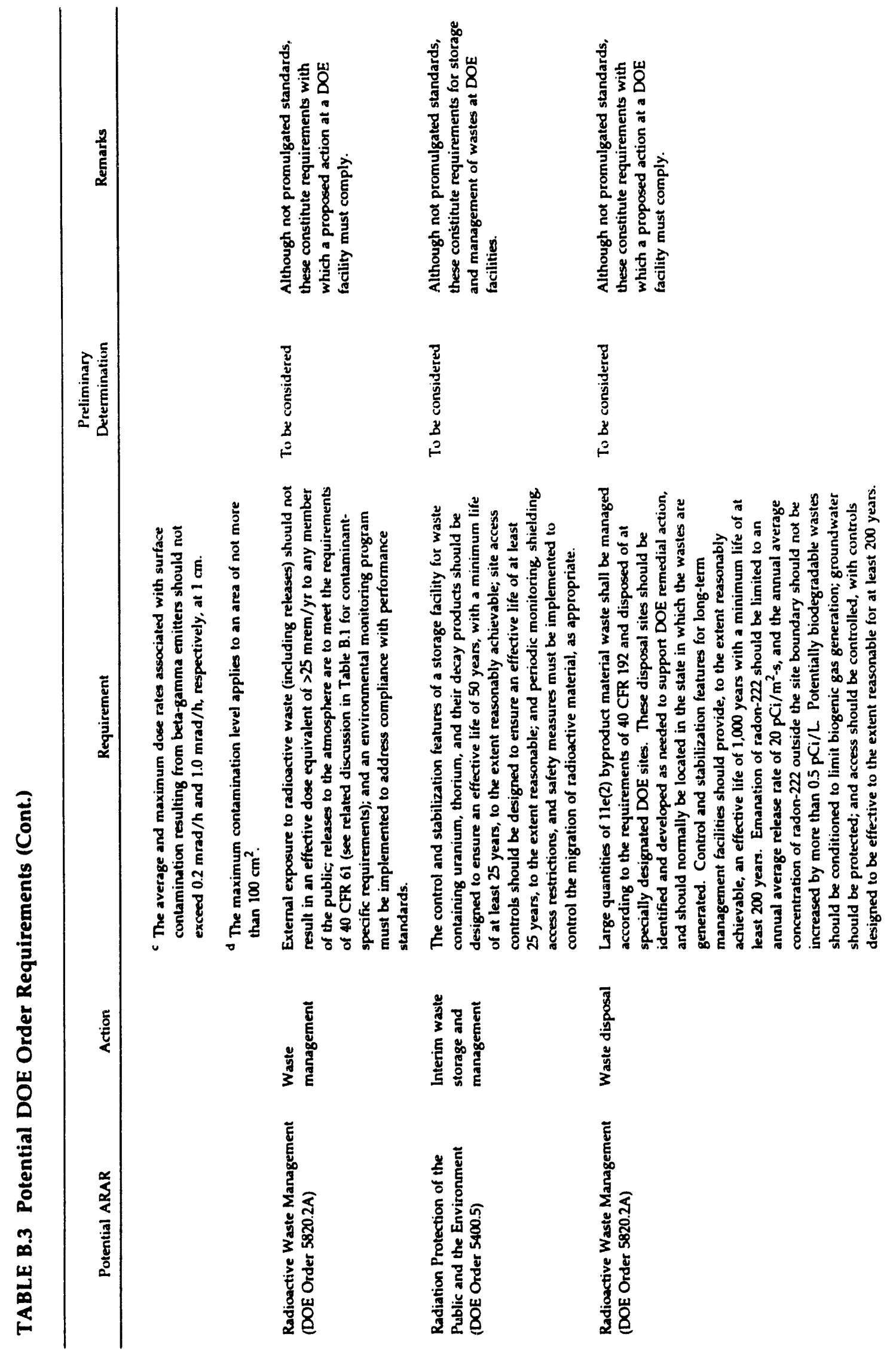




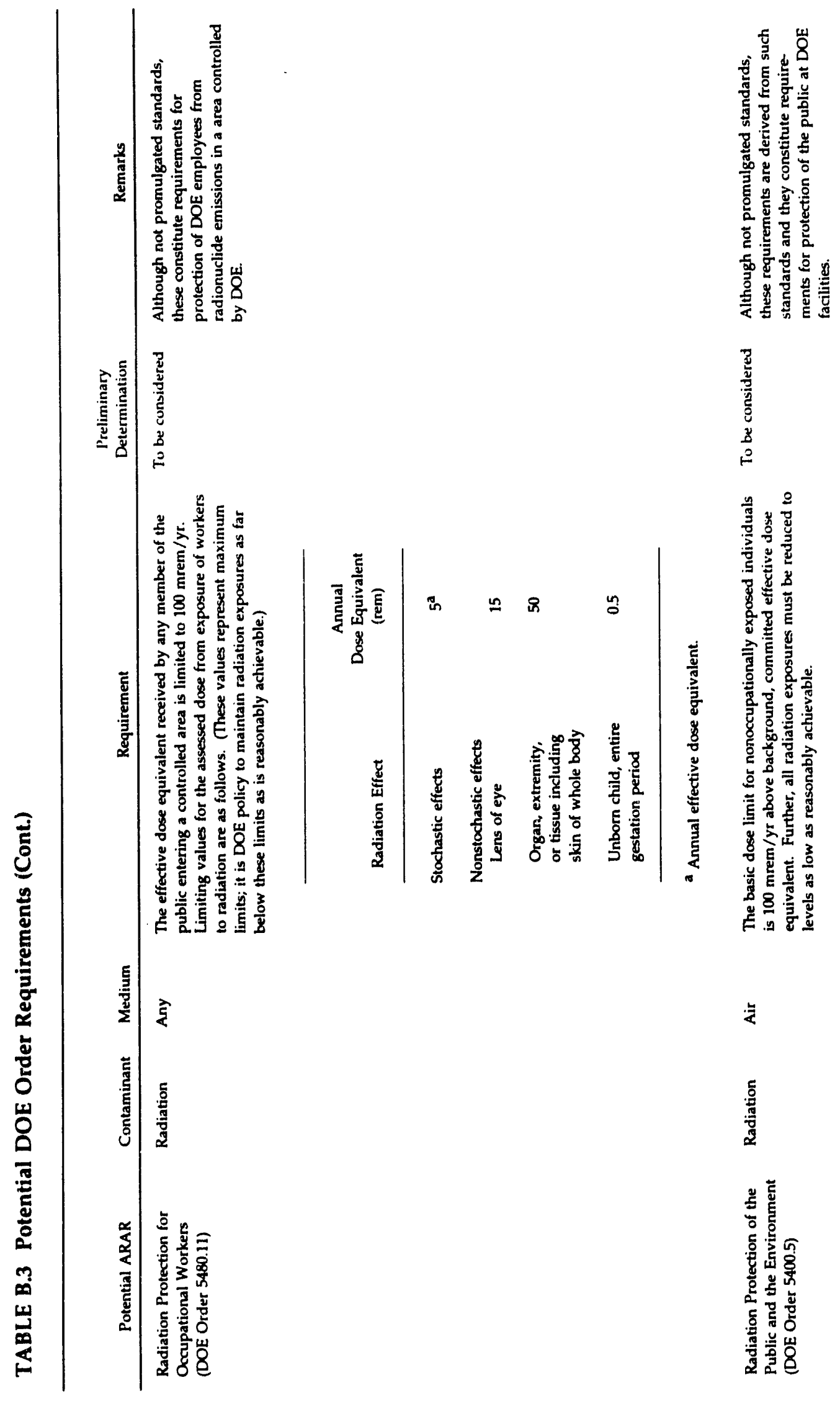




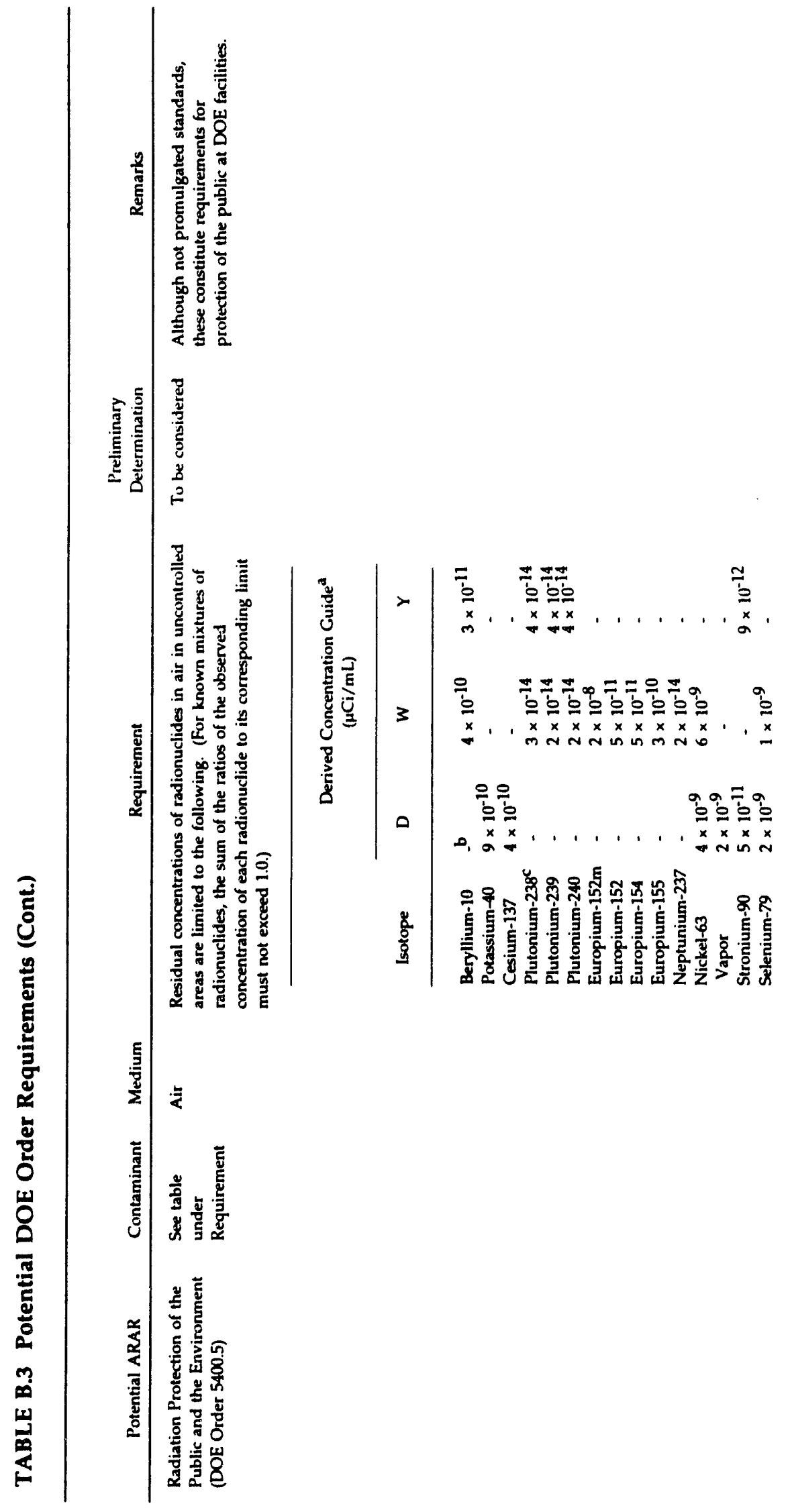




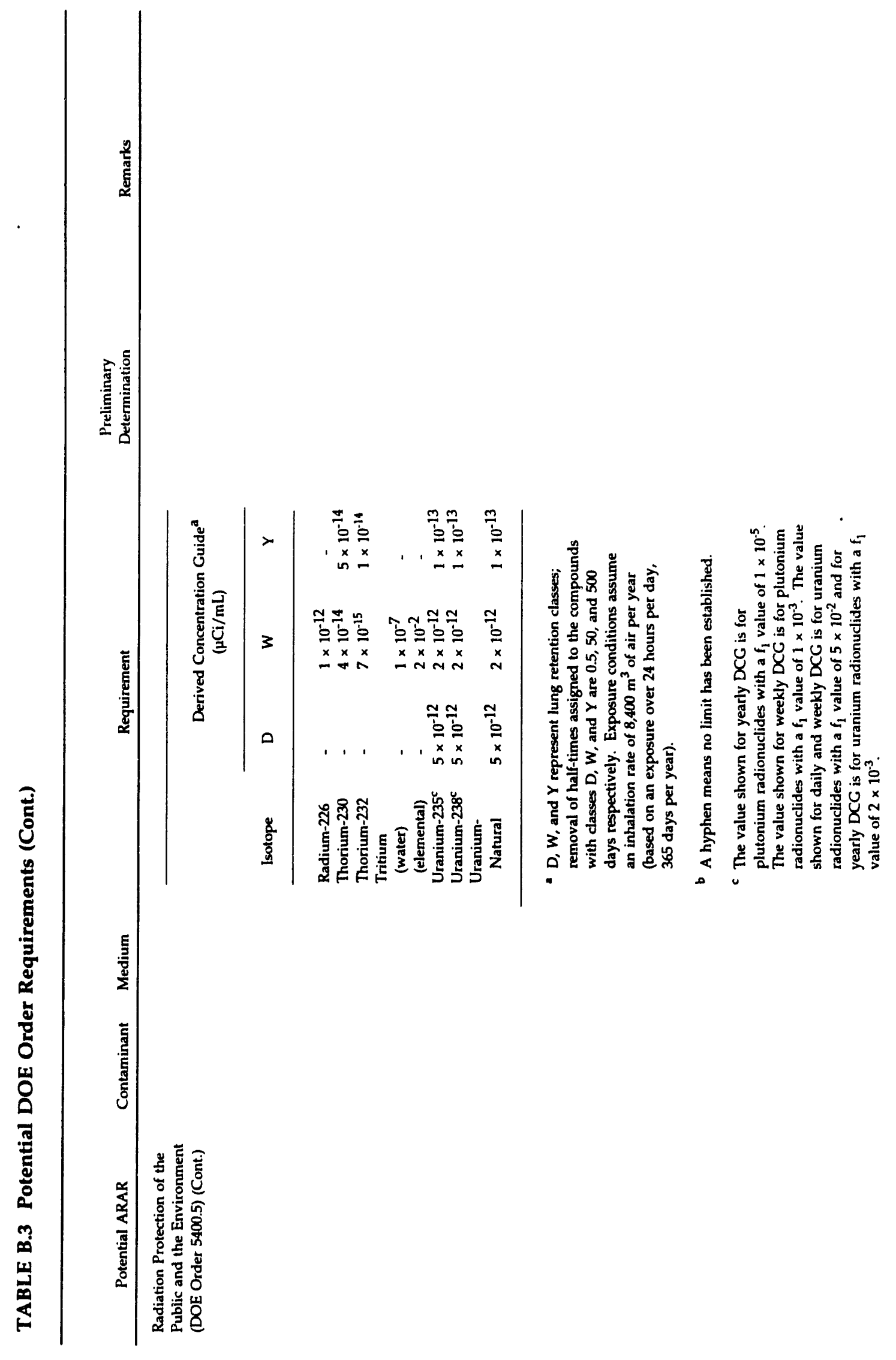




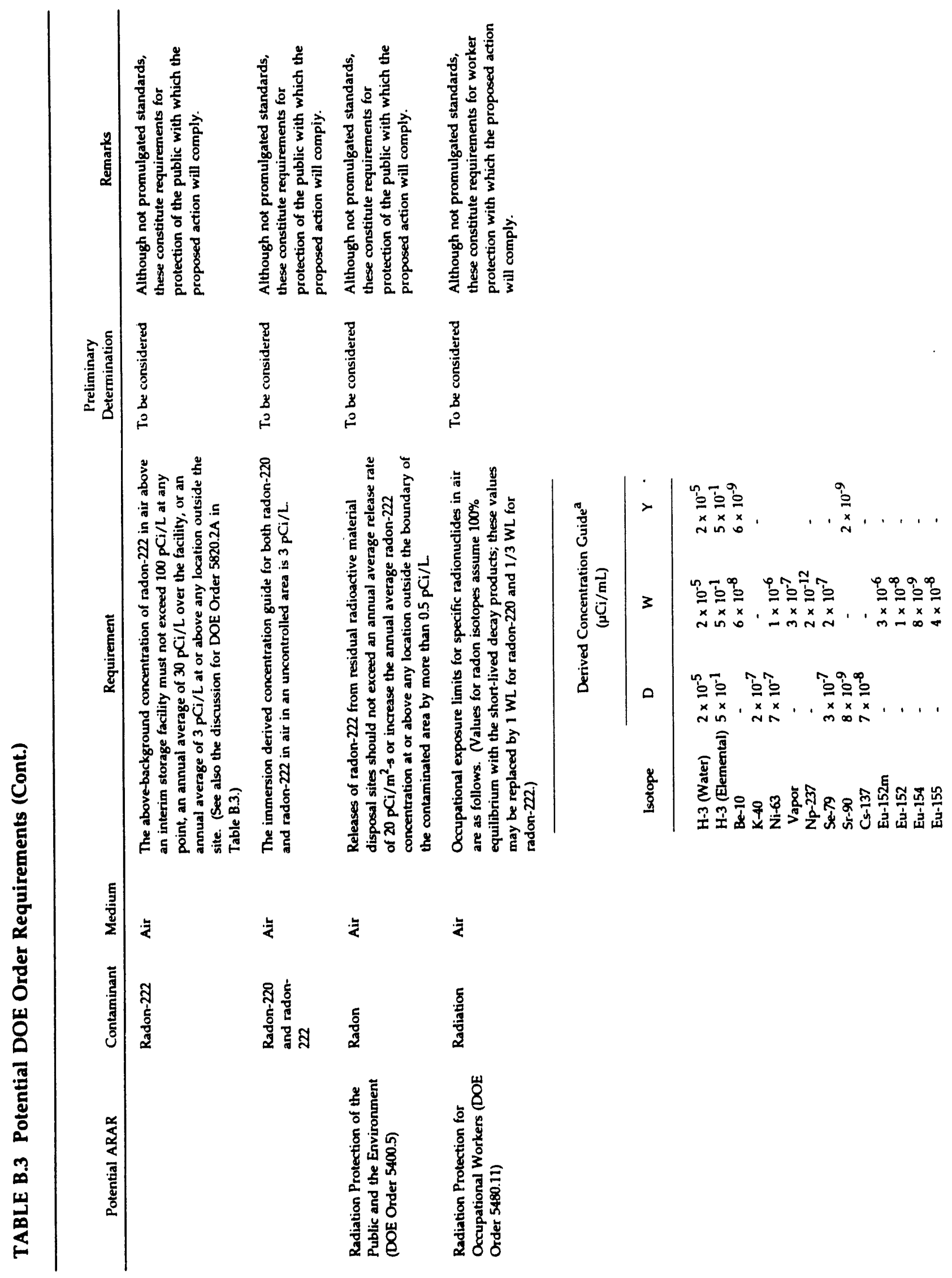




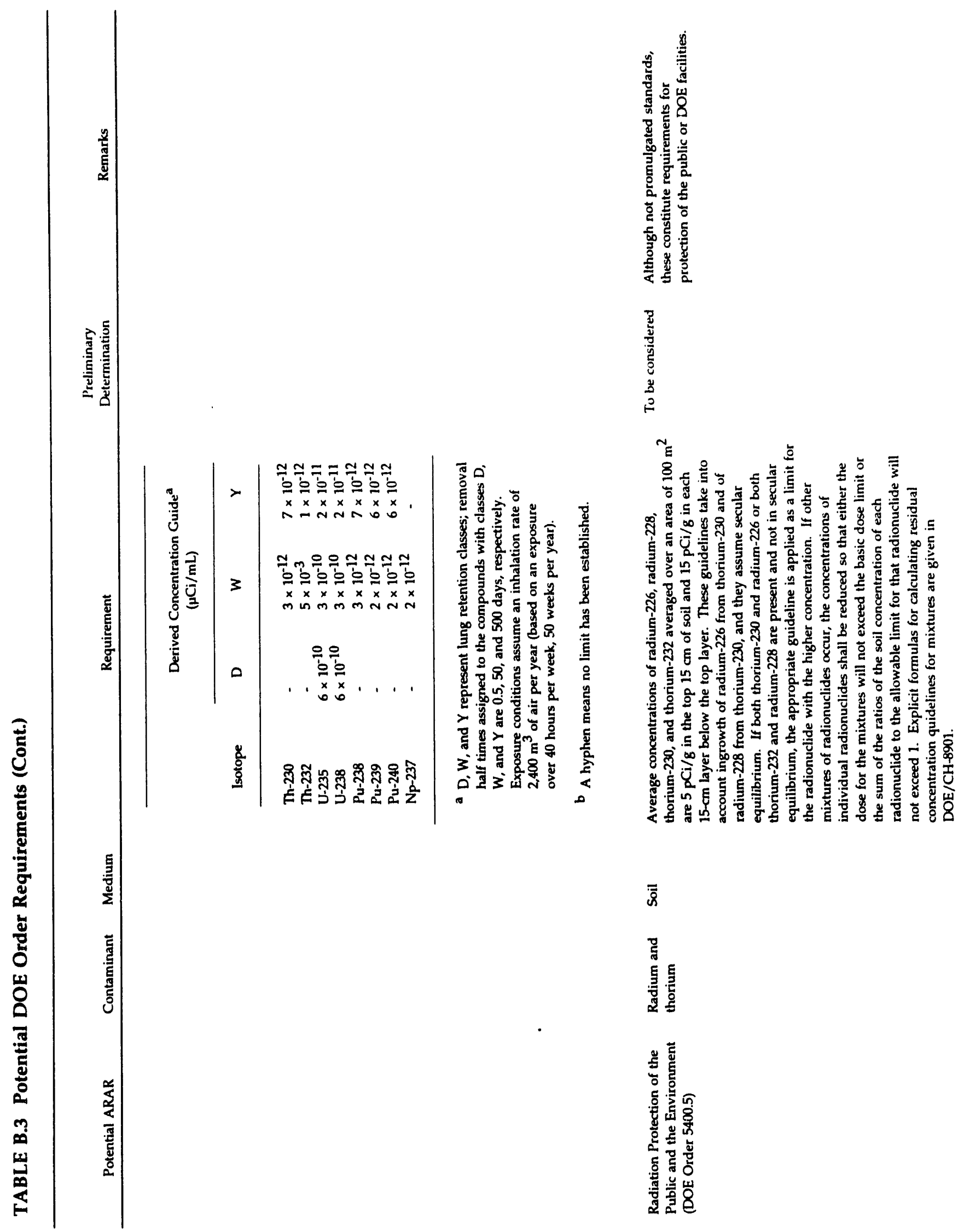




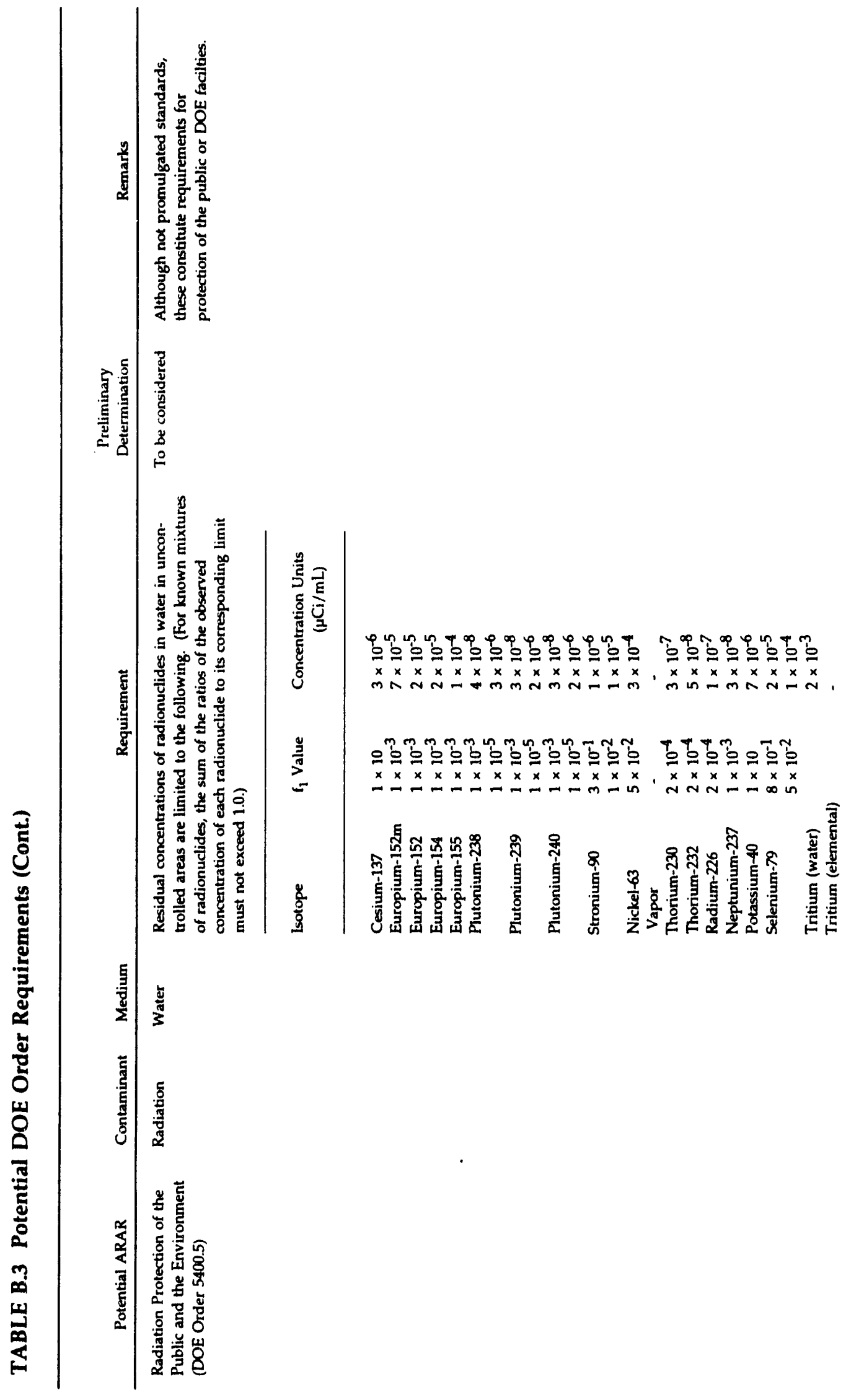




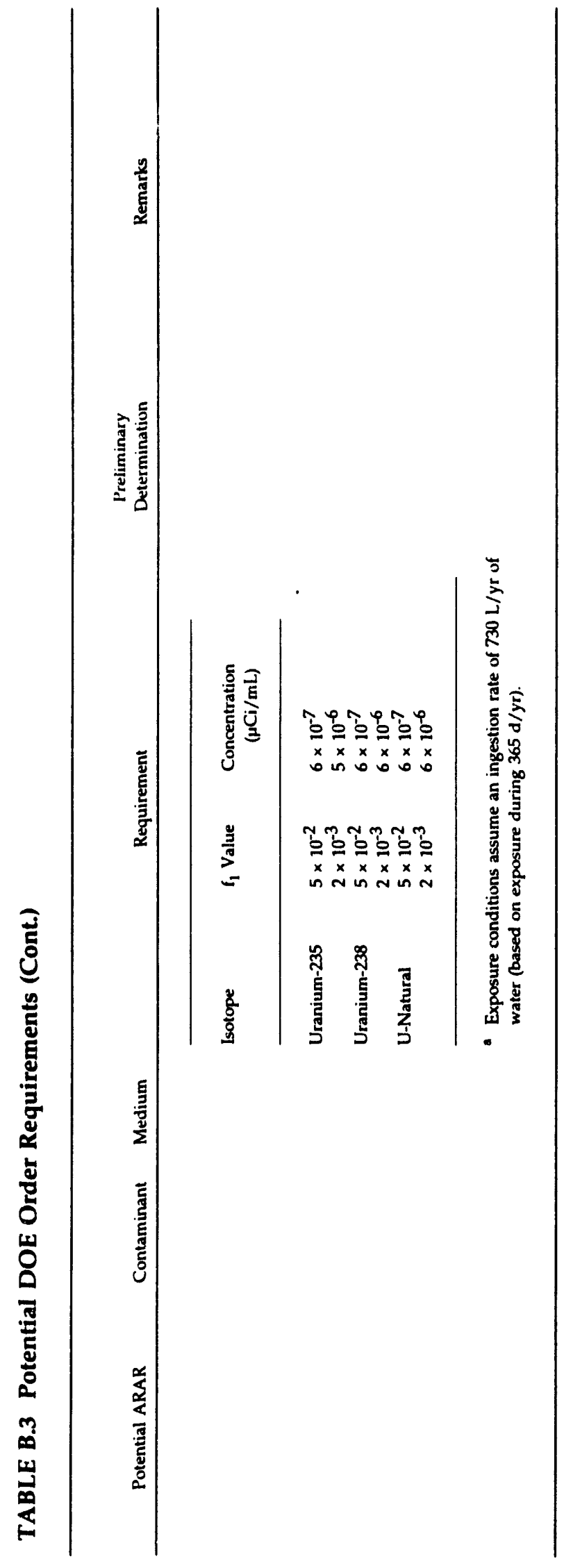




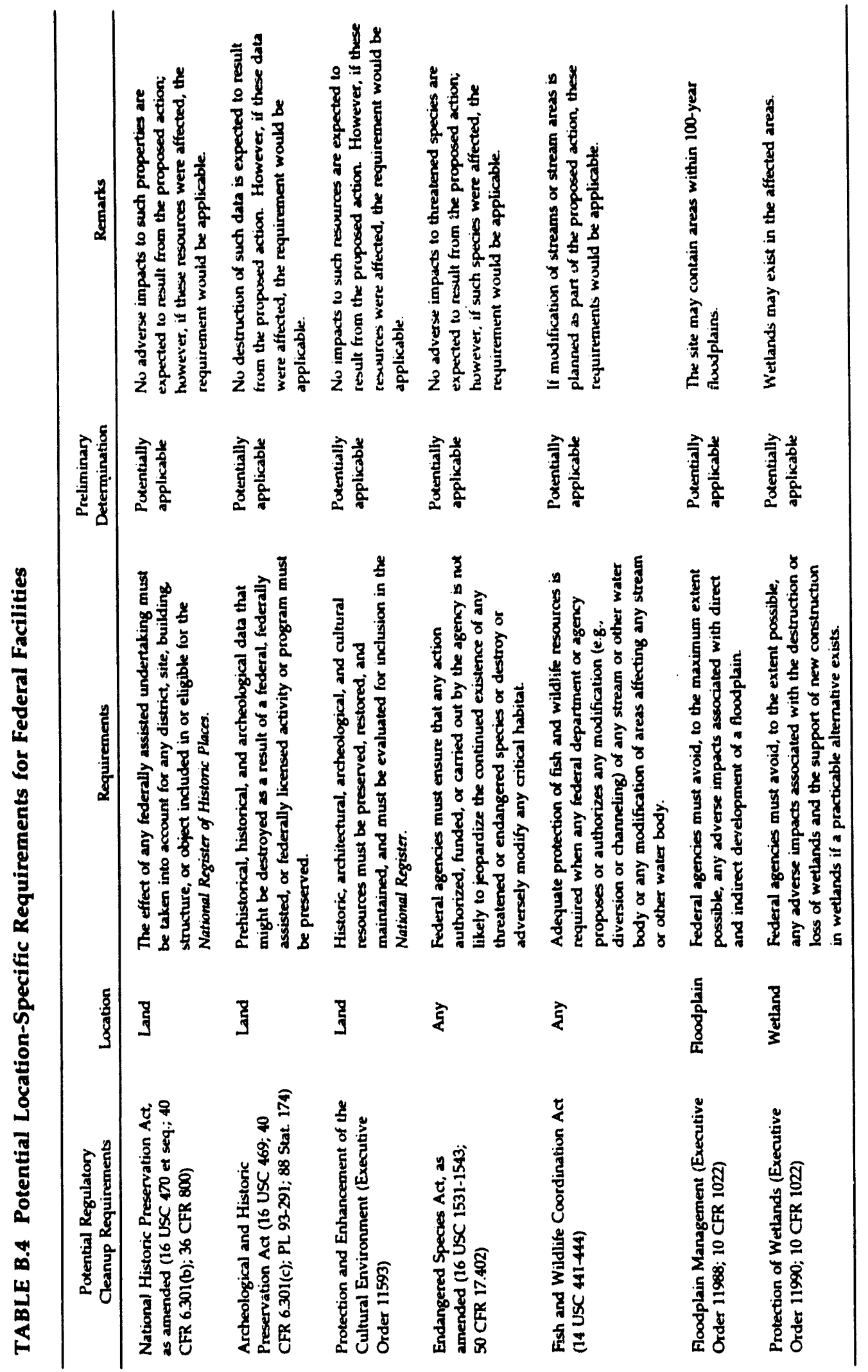




\section{APPENDIX C: \\ WELL ABANDONMENT PROCEDURES}

Source: U.S. Environmental Protection Agency, 1991, Handbook of Suggested Practices for Design and Installation of Ground-Water Monitoring Wells, pp. 130-133 in Chapter 8, "Well Abandonment," and Appendix C, "Abandonment of Test Holes, Partially Completed Wells and Completed Wells," EPA/600/4-89/034, Office of Research and Development, Washington, D.C., March. For ease of reading and use, this portion of the original was recreated: an optical character reader was used to scan the original document, and the text was cleaned up electronically. Only those references that appear in the excerpt have been included. 
$\mid \begin{array}{ll} \\ \mid & 156\end{array}$ 56 


\section{WELL ABANDONMENT}

\section{INTRODUCTION}

Unplugged or improperly plugged abandoned wells pose a serious threat to ground water. These wells serve as a pathway for surface pollutants to infiltrate into the subsurface and present an opportunity for various qualities of water to mix. Currently, many sites are being monitored for low concentrations of contaminants. As detection limits are lowered, it becomes more important to have confidence in the monitoring system. An improperly installed or maintained monitoring network can produce anomalous sample results. Proper abandonment is crucial to the dependability of the remaining or new installations.

The objectives of an abandonment procedure are to: 1) eliminate physical hazards; 2) prevent ground-water contamination, 3) conserve aquifer yield and hydrostatic head and 4) prevent intermixıng of subsurface water (United States Environmental Protection Agency, 1975; American Water Works Association, 1984). The purpose of sealing an abandoned well is to prevent any further disturbance to the pre-existing hydrogeologic conditions that exist within the subsurface. The plug should prevent vertical movement within the borehole and confine the water to the original zone of occurrence.

Many states have regulations specifying the approved procedures for abandonment of water supply wells. Some states require prior notification of abandonment actions and extensive documentation of the actual abandonment procedures. However, few states have specific requirements for abandonment of monitoring wells.

\section{WELL ABANDONMENT CONSIDERATIONS}

Selection of the appropriate method for abandonment is based on the information that has been compiled for each well. Factors that are considered include: 1) casing material, 2) casing condition, 3) diameter of the casing, 4) quality of the original seal, 5) depth of the well, 6) well plumbness, 7) hydrogeologic setting and 8) the level of contamination and the zone or zones where contamination occurs. The type of casing and associated tensile strength limit the pressure that can be applied when pulling the casing or acting as a guide when overdrilling. For example, PVC casing may break off below grade during pulling. The condition of any type of casing also may prohibit pulling. The diameter of the casing may limit the technique that is selected. For example, hollow-stem augers may not be effective for overdrilling large-diameter wells because of the high torque required to turn large-diameter augers. The quality of the original annular seal may also be a determining factor. For example, if a poor seal was constructed, then pulling the casing may be accomplished with minimum effort. The depth of the well may limit the technique applied. The plumbness of a well may influence technique by making overdrilling or casing pulling more difficult. The hydrogeology of the site may also influence the technique selected. For example, hollow-stem augers may be used for overdrilling in unconsolidated deposits but not in rock formations. The availability of a rig type and site conditions may also be 
determining factors. The level of contamination and zone in which contamination occurs may modify the choice of technique. If no cross-contanination can occur between various zones and contamination cannot enter from the surface, grouting the well from bottom to top without removing the casing may be sufficient

\section{WELL ABANDONMENT PROCEDURES}

Well abandonment procedures involve filling the well with grout. The well may be filled completely or seals placed in apprupriate zones and the well only partially filled with grout. Completely filling tise well minimizes the possibility of bore-hole collapse and shifting of seals. The material used to fiil the well can be either carefully selected natural material with a permeability that approximates the permeability of the natural formation or a grout mixture with a lower permeability. If more than one zone is present in the well, then either intermediate seals must be used with natural materials or the well must be grouted. Monitoring wells are most commonly abandoned by completely filling the well with a grout mixture.

Wells can be abandoned either by removing the casing or by leaving all or part of the casing in place and cutting the casing off below ground level. Because the primary purpose of well abandonment is to eliminate vertical fluid migration along the borehole, the preferred method of abandonment involves casing removal. If the casing is removed and the borehole is unstable, grout must be simultaneously emplaced as the casing is removed in order to prevent borehole collapse and an inadequate seal. When the casing is removed, the borehole can be sealed completely and there is less concern about channeling in the annular space or inadequate casing/grout seals. However, if the casing is left in place, the casing should be perforated and completely pressure-grouted $t u$ rnduce the possibility of annular channeling. Perforating small-diameter casings in situ is difficult, if not impossible.

Many different materials can be used to fill the borehole. Bentonite, other clays, sand, gravel, concrete and neat cement all may have application in certain abandonment situations. Appendix $\mathrm{C}$ contains recommendations for well abandonment that are provided by the American Water Works Association (1984). These guidelines address the use of different materials for filling the borehole in different situations. Regardless of the type of material or combination of materials used for monitoring well abandonment, the sealant must be free of contaminants and must minimize chemical alteration of the naturel ground-water quality. For example, neat cement should not be used in areas where the $\mathrm{pH}$ of the ground water is acidic. The ground water will attack the cement and reduce the effectiveness of the seal; the neat cement also raises the $\mathrm{pH}$ and alters ground-water chemistry.

\section{Procedures for Removing Casing}

If the well was not originally grouted, the casing may be pulled by hydraulic jacks ur by "bumping" the casing with a rig. A vibration hammer also may be used to speed up the task. Cising cutters can be used to separate the drive shoe from the bottom of the casing 
(Driscoll, 1986). If the well intake was installed by telescoping, the intake may be removed by sandlocking (United States Environmental Protection Agency, 1975).

A properly sized pulling pipe must be used to successfully implement the sandlocking technique. Burlap strips, 2 to 4 inches wide, and approximately 3 feet long are tied to the pulling pipe. The pipe is lowered into the borehole to penetrate approximately $2 / 3$ of the length of the well intake. The upper portion of the well intake above the burlap is slowly filled with clean angular sand by washing the sand into the well. The pulling pipe is then slowly lifted to create a locking effect. Constant pressure is applied and increased until the well intake begins to move. In some instances, jairring the pipe may assist in well intake removal, but in some cases this action may result in loss of the sand lock. As the well intake is extracted from the well, the sand packing and pipe are removed. Many contractors have developed variations of this sandlocking technique for specific situations. For example, slots can be cut in the pulling pipe at the level adjacent to the top of the well intake to allow excess sand to exit through the pulling pipe. These slots prevent the well intake from being overfilled and sandlocking the entire drill string. Slots can also be cut in the pipe just above the burlap so that sand can be backwashed or bailed from the inside pipe if the connection should need to be broken. Right and left-hand couplings located between the drill pipe and pulling pipe may be installed to disconnect the drill string if it becomes locked. Well intakes that are 2 to 6 inches in diameter can be removed by latch-type tools. For example, an elliptical plate cut in half with a hinge may be used. The plate folds as it is placed in the well and unfolds when lifted. If the well intake has a sump, the tool can be locked under the sump; if there is no simp, the tool can be locked under the well intake (Driscoll, 1986).

Another technique that may be used in conjunction with sandlocking involves filling the borehole with a clay-based drilling fluid through the pulling pipe while pulling the well intake and casing from the bottom. The fluid prevents the borehole from collapsing. The level of the fluid is observed to determine if the borehole is collapsing. Fluid rises if collapse is occurring. If fluid is falling, it is an indication that fluid is infiltrating into ihe surrounding formation. In this technique, the borehole is grouted from the bottom to the surface.

Overdrilling can also be used to remove casing from the borehole. In overdrilling, a large-diameter hollow-stem auger is used to drill around the casing. A large-diameter auger is used because a larger auger is less likely to veer off the casing during drilling. The hollow stow should be at least 2 inches larger than the casing that is being removed. For example, a 3 1/4-inch inside diameter auger should not be used to overdrill a 2-inch diameter casing. The augers are used to drill to the full depth of the previous boring. If possible, the casing should be pulled in a "long" string, or in long increments. If the casing sticks or breaks, jetting should be used to force water down the casing and out the well intake. If this technique fails, the augers can be removed one section at a time and the casing can be cut off in the same incremental lengths. After all casing has been removed, the hollow-stem augers are reinserted and rotated to the bottom of the borehole. All the debris from the auger interior should be cleaned out, the augers extracted and the borehole filled with grout by using a tremie pipe (Wisconsin Department of Natural Resources, 1985). The technique 
of overdrilling is not limited to hollow-stem augers. Overdrilling can also be accomplished by direct rotary techniques using air, foam or mud.

Limiting factors in overdrilling are the diameter of the well and the hydrogeology of the surrounding formation. When overdrilling, an attempt should be made to remove all annular sealant so a good seal can be obtained between the borehole wall and the grout. The plumbness of the original installation is also very important; if the well was not installed plumb, then overdrilling may be difficult.

A variation of overdrilling was used by Perrazo et al. (1984) to remove 4-inch PVC casing from monitoring wells. First, the well was filled with a thick bentonite slurry to prevent the PVC cuttings from settling in the borehole. The auger was regularly filled with slurry to keep the casing full and to form a mudcake on the wall. This mudcake served as a temporary seal until a permanent seal was installed. A hollow-stem auger was used with a 5 to 10-foot section of $\mathrm{NW}$ rod welded onto the lead auger for use as a guide in drilling out the PVC casing. The auger was rotated, and the casing was cut and spiraled to the surface. A 2-inch diameter roller bit was threaded onto a drill rod and advanced to ensure the bottom area would be sealed to the original depth. The grout mixture was pumped down the drill stem and out the roller bit, displacing the bentonite slurry and water to the surface. In wells where there was not sufficient pressure to displace the bentonite slurry and standing water, the roller bit and drill stem were removed, a pressure cap was threaded onto the top auger flight and grout was pumped through the cap until increasing pressure forced the grout to displace the bentonite slurry and water. The augers were then removed and the grout was alternately "topped off as each flight was removed.

Another technique involves jetting casing out of the well with water. If the casing sticks or breaks off, a small-diameter fish tail-type bit is connected to an A-rod to drill out the thermoplastic casing. The drilling fluid flushes the cuttings to the surface. After the borehole is cleaned, a tremie pipe is used to emplace grout from the bottom to the surface (Wisconsin Department of Natural Resources, 1985).

\section{Procedures for Abandonment without Casing Removal}

If the casing is in poor condition, the interval adjacent to the water-bearing zones can be ripped or perforated with casing rippers, and then the casing is filled and pressure grouted (United States Environmental Protection Agency, 1975; Driscoll 1986). A concern when using this method is the accurate placement and effectiveness of the cuts (Perazzo et al., 1984). Casing may be gun-perforated by using a device that fires steel projectiles through the casing and into the formation. A jet-perforating device may be used that is similar to the gun-perforator except that a pre-shaped charge of high explosives is used to burn holes through the casing (Ingersoll-Rand, 1985). The top portion of the casing is then pulled so that a watertight plug in the upper 15 to 20 feet can be attained. This step may be omitted where the annular space was originally carefully grouted (Driscoll, 1986). 


\section{Using Plugs}

Three types of bridge plugs can be used to isolate hydraulic zones. These include: 1) permanent bridge seals, 2) intermediate seals and 3) seals at the uppermost aquifer. The permanent bridge seal is the most deeply located seal that is used to form a "bridge" upon which fill material can be placed. Permanent bridge seals prevent cross-contamination between lower and upper water-bearing zones. Permanent seals are comprised of cement. Temporary bridges of neoprene plastic or other elastomers can provide support for a permanent bridge during installation (United States Environmental Protection Agency, 1975).

Intermediate seals are located between water-bearing zones to prevent intermixing of different-quality water. Intermediate seals are comprised of cement, sand/cement or concrete mixes and are placed adjacent to impermeable zones. The remaining permeable zones are filled with clean disinfected sand, gravel or other material (United States Environmental Protection Agency, 1975).

The seal at the uppermost aquifer is located directly above the uppermost productive zone. The purpose is to seal out surface water. An uppermost aquifer seal is typically comprised of cement, sand/cement or concrete. In artesian conditions, this seal prevents water from flowing to the surface or to shallower formations (United States Environmental Protection Agency, 1975). This plugging technique is generally used to isolate usable and non-usable zones and has been used extensively in the oil and gas industry.

If artesian conditions are encountered, several techniques can be used to abandon the well. To effectively plug an artesian well, flow must be stopped and the water level lowered during seal emplacement. The water level can be lowered by: 1) drawing down the well by pumping nearby wells, 2) placing fluids of high specific gravity in the borehole or 3) elevating the casing high enough to stop the flow (Driscoll, 1986). If the rate of flow is high, neat cement or sand/cement grout can be piped under pressure, or a packer can be located at the bottom of the confining formation above the production zone (United States Environmental Protection Agency, 1975). Fast-setting cement can sometimes be used in sealing artesian wells (Herndon and Smith, 1984).

\section{GROUTING PROCEDURES FOR PLUGGING}

All materials used for grouting should be clean and stable; water used should be free from oil and other contaminants (Driscoll, 1986). Grout should be applied in one continuous grouting procedure from bottom to top to prevent segregation, dilution and bridging of the sealant. The end of the tremie pipe should always remain immersed in the slurry of grout throughout the emplacement procedure. Recommendations for grout proportions and emplacement procedures are discussed in the section entitled "Annular Seals."

Many states permit or recommend a cement/bentonite mixture. The bentonite possesses swelling characteristics that make it an excellent plugging material (Van Eck, 1978). The grout mixture used should be compatible with soil and water chemistry. For 
example, a salt-saturated cement should be used for cementing in a salt-saturated area. The cement/bentonite mixture should not extend through the vadose zone to the land surface or be used in areas of low soil moisture because cracking and channeling due to desiccation can allow surface water to infiltrate along the casing (Driscoll, 1986). To ensure that the borehole was properly grouted, records should be kept of the calculated volume of the borehole and the volume of grout that was used; any discrepancy should be explained.

A concrete cap should be placed on the top of a cement/ bentonite plug. The concrete cap should be marked with a piece of metal or iron pipe and then covered by soil. The metal allows for easy location of the well in the future by a metal detector or magnetometer.

\section{CLEAN-UP, DOCUMENTATION AND NOTIFICATION}

After abandonment is accomplished, proper site clean-up should be performed. For example, any pits should be back-filled and the area should be left clean (Fairchild and Canter, 1984). Proper and accurate documentation of all procedures and materials used should be recorded. If regulations require that abandonment of wells be reported, information should be provided on the required forms and in compliance with the state regulations. Table 43 shows information that is typically recorded on a well abandonment form. The location of abandoned wells should be plotted on a map and referenced to section lines, lot lines, nearby roads and buildings as well as any outstanding geological features (Aller, 1984). 
TABLE 43 Well Abandonment Data (After Wisconsin Department of Natural Resources, 1985)

- Name of property owner

- Address of owner/property

- Well location (street, section number, township and range)

- Type of well installation method and date (drilled, driven, bored, dug), purpose of well (OW, PIEZ, LYS)

- Depth of well

- Diameter of well

- Depth of casing

- Depth to rock

- Depth to water

- Formation type

- Material overlying rock (clay, sand, gravel, etc.)

- Materials and quantities used to fill well in specific zones, detailing in which formations and method used

- Casing removed or left in place

- Signature of person doing work

- Address of firm 


\section{References}

Aller, Linda, 1984. Methods for determining the location of abandoned wells; United States Environmental Protection Agency, EPA-600/2-83-123, National Water Well Association, Dublin, Ohio, 130 pp.

American Water Works Association, 1984. Appendix I: Abandonment of test holes, partially completed wells and completed wells; American Water Works Association Standard for Water Wells, American Water Works Association, Denver, Colorado, pp. 45-47.

Driscoll, Fletcher G., 1986. Ground water and wells; Johnson Division, St. Paul, Minnesota, $1089 \mathrm{pp}$.

Fairchild, Deborah M. and Larry W. Canter, 1984. Abandoned wells and ground water; Ground Water Age, vol. 19, no. 3, pp. 33-39.

Herndon, Joe and Dwight K. Smith, 1984. Setting down-hole plugs: a state-of-the-art; Proceedings of the First National Conference on Abandoned Wells: Problems and Solutions, University of Oklahoma, Environmental and Ground-Water Institute, Norman., Oklahoma, pp. 227-250.

Ingersoll-Rand, 1985. Drilling terminology; Ingersoll-Rand Rotary Drill Division, Garland, Texas, $125 \mathrm{pp}$.

Perazzo, James A., Richard C. Dorrier and James P. Mack, 1984. Long-term confidence in ground water monitoring systems; Ground Water Monitoring Review, vol. 4, no. 4, pp. 119-123.

United States Environmental Protection Agency, 1975. Manual of water well construction practices; United States Environmental Protection Agency, Office of Water Supply, EPA-570/9-75-001, 156 pp.

Van Eck, Orville J., 1978. Plugging procedures for domestic wells; Public Information Circular Number 11, Iowa Geological Survey, Des Moines, Iowa, 7 pp.

Wisconsin Department of Natural Resources, 1985. Guidelines for monitoring well installation, Appendix B; Bureau of Solid Waste Management, Madison, Wisconsin, $35 \mathrm{pp}$. 


\section{Appendix C}

\section{(Supplement to Chapter 8) \\ Abandonment of Test Holes, Partially Completed Wells and Completed Wells (American Water Works Association, 1984)}

\section{Section 1.1 - General}

The recommendations contained in this appendix pertain to wells and test holes in consolidated and unconsolidated formations. Each sealing job should be considered as an individual problem, and methods and materials should be determined only after carefully considering the objectives outlined in the standard.

\section{Section 1.2 - Wells in Unconsolidated Formations}

Normally, abandoned wells extending only into consolidated formations near the surface and containing water under water-table conditions can be adequately sealed by filling with concrete, grout, neat cement, clay, or clay and sand. In the event that the water-bearing formation consists of coarse gravel and producing wells are located nearby, care must be taken to select sealing materials that will not affect the producing wells. Concrete may be used if the producing wells can be shut down for a sufficient time to allow the concrete to set. Clean, disinfected sand or gravel may also be used as fill material opposite the waterbearing formation. The remainder of the well, especially the upper portion, should be filled with clay, concrete, grout, or neat cement to exclude surface water. The latter method, using clay as the upper sealing material, is especially applicable to large diameter abandoned wells.

In gravel-packed, gravel-envelope, or other wells in which coarse material has been added around the inner casing to within 20 to $30 \mathrm{ft}(6.1$ to $9.1 \mathrm{~m})$ of the surface, sealing outside the casing is very important. Sometimes this sealing may require removal of the gravel or perforation of the casing.

\section{Section 1.3 - Wells in Creviced Formations}

Abandoned wells that penetrate limestone or other creviced or channelized rock formations lying immediately below the surface deposits should preferably be filled with concrete, grout, or neat cement to ensure permanence of the seal. The use of clay or sand in such wells is not desirable because finegrained fill material may be displaced by the flow of water through crevices or channels. Alternate layers of coarse stone and concrete may be used for fill material through the water-producing horizon if limited vertical movement of water in the formation will not affect the quality or quantity of water in producing wells. Only concrete, neat cement, or grout should be used in this type of well. The portion of the well between a point 10 to $20 \mathrm{ft}$ ( 3.0 to $6.1 \mathrm{~m}$ ) below and a point 10 to $20 \mathrm{ft}$ ( 3.0 to 6.1 above should be sealed and a plug of sealing material formed above the creviced formation. Clay 
or sand may be used to fill the upper part of the well to within $20 \mathrm{ft}(6.1 \mathrm{~m})$ of ground level. The upper $20 \mathrm{ft}(6.1 \mathrm{~m})$ should be sealed with concrete or cement grout.

\section{Section 1.4 - Wells in Noncreviced Rock Formations}

Abandoned wells encountering non-creviced sandstone or other water-bearing consolidated formations below the surface deposits may be satisfactorily sealed by filling the entire depth with clay, provided there is no movement of water in the well. Clean sand, disinfected if other producing wells are nearby, may also be used through the sandstone up to a point 10 to $20 \mathrm{ft}$ ( 3.0 to $6.1 \mathrm{~m}$ ) below the bottom of the casing. The upper portion of this type of well should be filled with concrete, neat cement, grout or clay to provide an effective seal against entrance of surface water. If there is an appreciable amount of upward flow, pressure cementing or mudding may be advisable.

\section{Section 1.5 - Multiple Aquifer Wells}

Some special problems may develop in sealing wells extending into more than one aquifer. These wells should be filled and sealed in such a way that exchange of water from one aquifer to another is prevented. If no appreciable movement of water is encountered, filling with concrete, neat cement, grout, or alternate layers of these materials and sand will prove satisfactory. When velocities are high, the procedures outlined in Sec. I.6 are recommended. If alternate concrete plugs or bridges are used, they should be placed in known nonproducing horizons or, if locations of the nonproducing horizons are not known, at frequent intervals. Sometimes when the casing is not grouted or the formation is noncaving, it may be necessary to break, slit, or perforate the casing to fill any annular space on the outside.

\section{Section 1.6 - Wells with Artesian Flow}

The sealing of abandoned wells that have a movement between aquifers or to the surface requires special attention. Frequently the movements of water may be sufficient to make sealing by gravity placement of concrete, cement grout, neat cement, clay or sand impractical. In, such wells, large stone aggregate (not more than one third of the diameter of the hole), lead wool, steel shavings, a well packer, or a wood or cast-lead plug or bridge will be needed to restrict the flow and thereby permit the gravity placement of sealing material above the formation producing the flow. If preshaped or precast plugs are used, they should be several times longer than the diameter of the well, to prevent tilting.

Since it is very important in wells of this type to prevent circulation between formations, or loss of water to the surfaces or to the annular space outside the casing, it is recommended that pressure cementing, using the minimum quantity of water that will permit handling, be used. The use of pressure mudding instead of this process is sometimes permissible. 
In wells in which the hydrostatic head producing flow to the surface is low, the movement of water may be arrested by extending the well casing to an elevation above the artesian pressure surface. Previously described sealing methods suitable to the geologic conditions can then be used.

\section{Section 1.7 - Sealing Materials}

A number of materials that can be used for sealing wells satisfactorily, including concrete, cement grout, neat cement, clay, sand, or combinations of these materials, are mentioned in this appendix. Each material has certain characteristics and distinctive properties; therefore, one material may be especially suited for doing a particular job. The selection of the material must be based on the construction of the well, the nature of the formations penetrated, the material and equipment available, the location of the well with respect to possible sources of contamination, and the cost of doing the work.

Concrete is generally used for filling the upper part of the well or water-bearing formations, for plugging short sections of casings, or for filling large-diameter wells. Its use is cheaper than neat cement or grout, and it makes a stronger plug or seal. However, concrete will not penetrate seams, crevices, or interstices. Furthermore, if not properly placed, the aggregate is likely to separate from the cement.

Cement grout or neat cement and water are far superior for sealing small openings, for penetrating any annular space outside of casings, and for filling voids in the surrounding formation. When applied under pressure, they are strongly favored for sealing wells under artesian pressure or those encountering more than one aquifer. Neat cement is generally preferred to grout because it does not separate.

Clay, as a heavy mud-laden or special clay fluid applied under pressure, has most of the advantages of cement grout. Its use is preferred by some competent authorities particularly for sealing artesian wells. Others feel that it may, under some conditions, eventually be carried away into the surrounding formations.

Clay in a relatively dry state, clay and sand, or sand alone may be used advantageously as sealing materials, particularly under water-table conditions where diameters are large, depths are great, formations are caving, and there is no need for achieving penetration of openings in casings, liners, or formations, or for obtaining a watertight seal at any given spot.

Frequently combinations of these materials are necessary. The more expensive materials are used when strength, penetration, or water tightness are needed. The less expensive materials are used for the remainder of the well. Cement grout or neat cement is now being mixed with bentonite clays and various aggregates. Superior results and lower cost are claimed for such mixtures. 


\section{Reference}

American Water Works Association, 1984. Appendix I: Abandonment of test holes, partially completed wells and completed wells; American Water Works Association Standard for Water Wells, American Water Works Association, Denver, Colorado, pp. 45-47. 

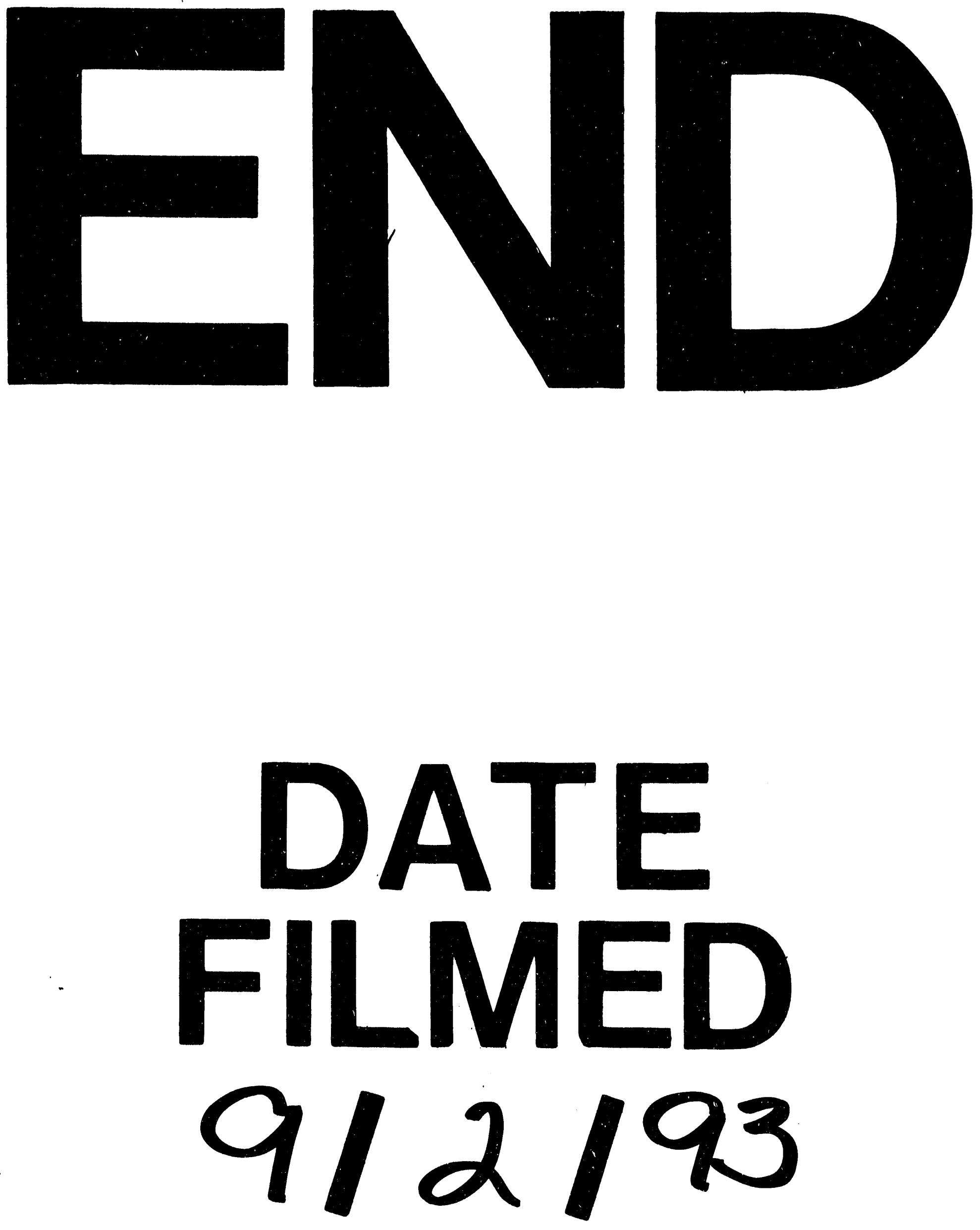
